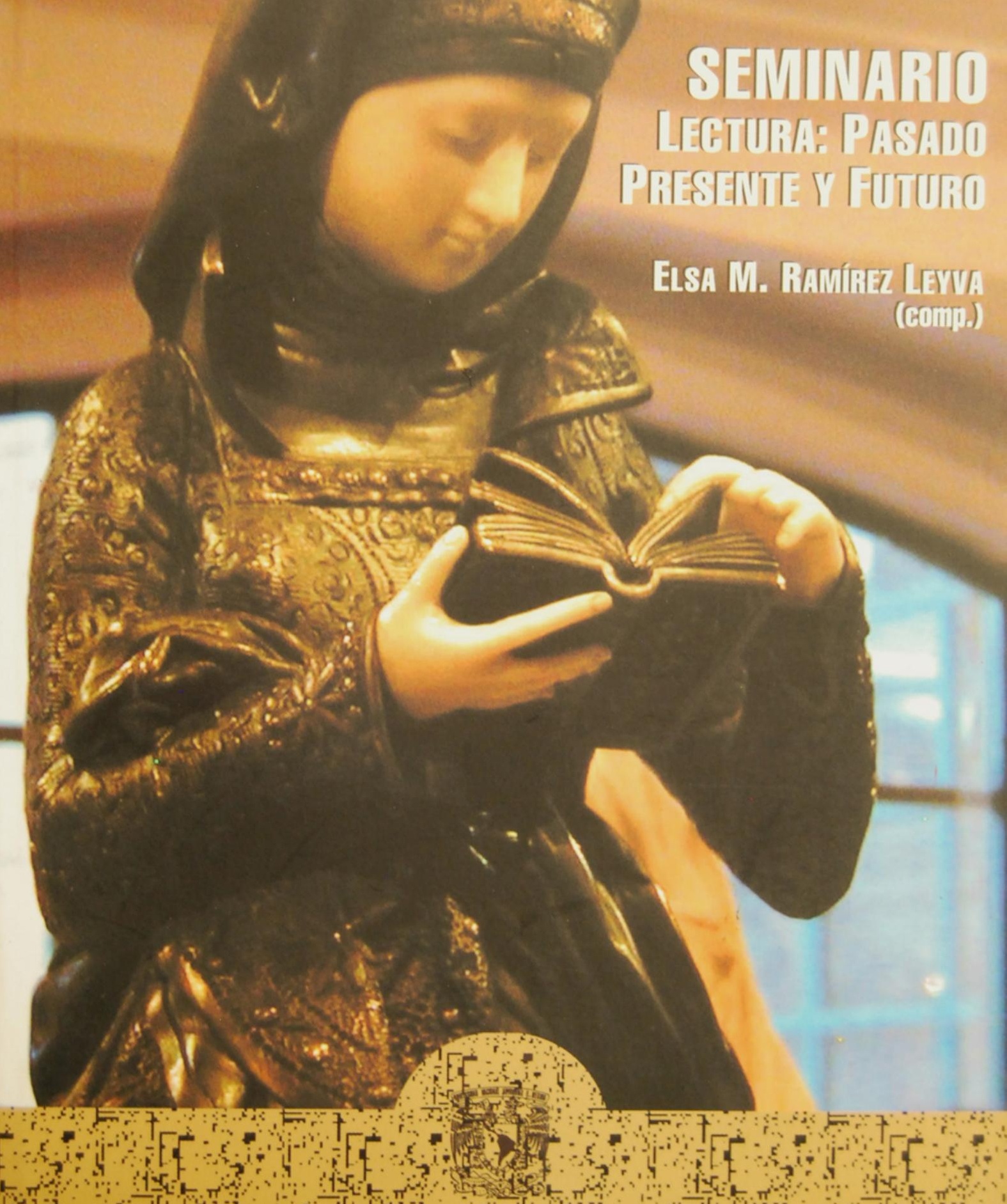

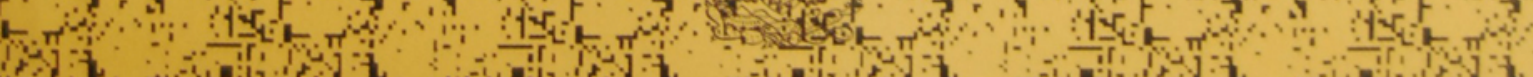




\section{La presente obra está bajo una licencia de:}

\section{http://creativecommons.org/licenses/by-nc-sa/3.0/deed.es MX}

\section{Atribución-No Comercial-Licenciamiento Reciproco 3.0 Unported}

Eres libre de:

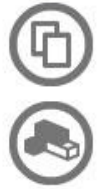

copiar, distribuir y comunicar públicamente la obra

hacer obras derivadas

Bajo las condiciones siguientes:

Atribución - Debes reconocer la autoría de la obra en los términos

especificados por el propio autor o licenciante.

No comercial - No puedes utilizar esta obra para fines comerciales.

Licenciamiento Recíproco - Si alteras, transformas o creas una obra a

partir de esta obra, solo podrás distribuir la obra resultante bajo una licencia

igual a ésta.

\section{Esto es un resumen fácilmente legible del: texto legal (de la licencia completa)}

En los casos que sea usada la presente obra, deben respetarse los términos especificados en esta licencia.
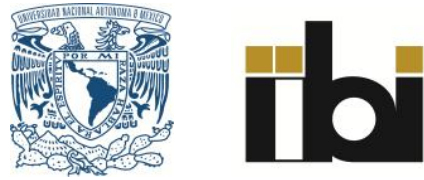


\section{Lectura: pasado, presente y futuro}


COLECCIÓN

SISTEMAS BIBLIOTECARIOS DE INFORMACIÓN Y SOCIEDAD Centro Universitario de Investigaciones Bibliotecológicas 


\title{
Lectura: pasado, presente y futuro
}

Memoria del Seminario Lectura: pasado, presente y futuro.

Del 29 de septiembre al 2 de octubre de 2003

\author{
Compiladora \\ Elsa Margarita Ramírez Leyva
}

Universidad Nacional Autónoma de México 2005 


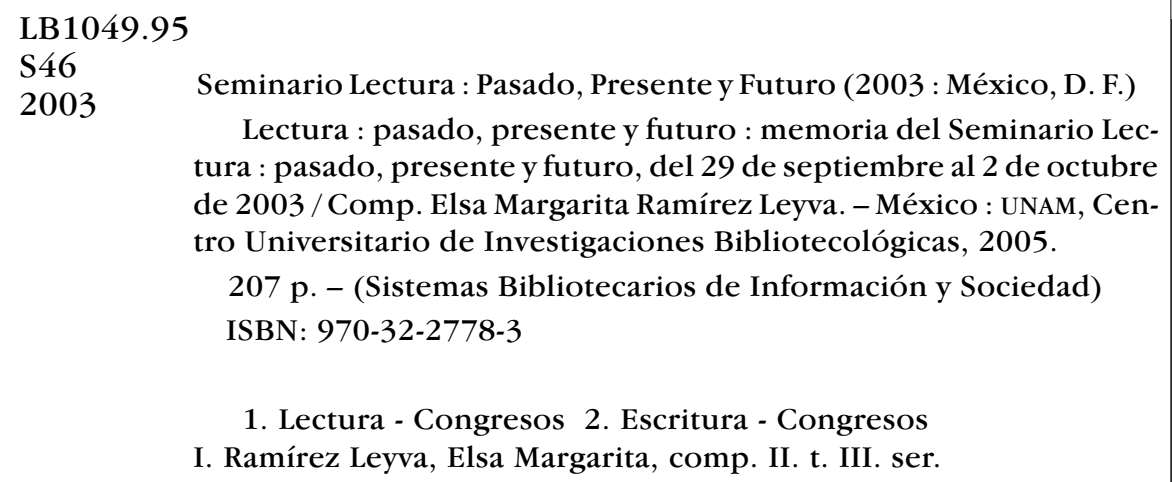

Apoyo en la compilación: Martha Ibáñez Marmolejo Diseño de portada: Ignacio Rodríguez Sánchez

Fotografía en cubierta

Autor: Albert-Ernest Carrier-Belleuse

Título: Lectora

c. $\mathbf{1 8 8 0}$

Técnica: Marfil y bronce con patina plateada

Col. Museo Soumaya

Primera Edición 2005

DR ( ) UNIVERSIDAd NACIONAL AUTÓNOMA DE MÉXICO

Ciudad Universitaria, 04510, México D.F.

Impreso y hecho en México

ISBN: 970-32-2778-3 
Participantes

Christine Garbe

Daniel Goldin

Didier Álvarez Zapata

Filiberto Felipe Martínez Arellano

Juan Domingo Argüelles

Juan Ros García

Michèle Petit

Noé Jitrik 



\section{Contenido}

PRESENTACIÓN . . . . . . . . . . . . . . . . . . . . . . . 1

Elsa M. Ramírez Leyva

LA CONTRIBUCIÓN DEL CUIB A LA INVESTIGACIÓN

DE LA LECTURA . . . . . . . . . . . . . . . . . . . . . . . . . 19

Filiberto Felipe Martínez Arellano

El EXTRAÑO OBJETO QUE NOS REÚNE . . . . . . . . . . . . . . . . 45

Michèle Petit

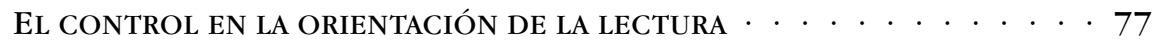
Juan Ros García

SOBRE LA MITOLOGÍA BIENINTENCIONADA DE LA LECTURA

TRES APOSTILLAS AL LIBRO ¿QUÉ LEEN LOS QUE

NO LEEN? . . . . . . . . . . . . . . . . . . . . . . . . . . . 86

Juan Domingo Argüelles

LA LECTURA EN LOS TIEMPOS DE INTERNET $\ldots$

Elsa M. Ramírez Leyva

PASADO, PRESENTE Y FUTURO DE LA LECTURA: ALGUNOS

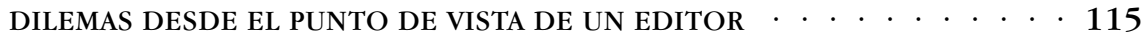

Daniel Goldin

INVESTIGACIÓN DE LA LECTURA EN ALEMANIA.

MÉTODOS Y RESULTADOS . . . . . . . . . . . . . . . . . . . 128

Christine Garbe 
ALLENDE LOS LINDEROS. HACIA LA INTEGRACIÓN

DE ENFOQUES EN LOS ESTUDIOS DE

LECTURA Y LA ESCRITURA. . . . . . . . . . . . . . . . . . . . . . . . . 160

Didier Álvarez Zapata

DE LA LECTURA Y LA ESCRITURA Y SUS RELACIONES CON LA

POLÍTICA: ALGUNAS PERSPECTIVAS DE COMPRENSIÓN

DESDE LOS LENGUAJES POLÍtICOS • . . . . . . . . . . . . . . . . . . . 177

Didier Álvarez Zapata

LECTOR: SER O NO SER. . . . . . . . . . . . . . . . . . . . . . . . . . . 195

Noé Jitrik

LOS PONENTES . . . . . . . . . . . . . . . . . . . . . . . . . 203 


\title{
Presentación
}

\author{
ElSa MARgarita RAMÍREZ LEYVA
}

\section{LA INTENCIÓN DEL SEMINARIO LA LECTURA: PASADO, PRESENTE Y FUTURO}

a lectura de textos, tanto su enseñanza como su práctica, se ha cultivado en los ámbitos educativos, religiosos y domésticos. En

canto su estudio había permanecido en el ámbito de la pedagogía. No obstante en el último tercio del siglo Xx la lectura formaba ya parte de las problemáticas culturales y sociales incorporadas en las agendas de investigación de disciplinas que, mediante abordajes teóricos metodológicos propios, han empezado a desentrañar la diversidad de factores que participan en la conformación de las prácticas de lectura. Algunos de estos factores se refieren a las especificidades propias de la historia personal del sujeto ante la lectura, en tanto otros mencionan circunstancias sociales, económicas, políticas, culturales y tecnológicas. Esos estudios hacen evidente que ambos aspectos, sociales e individuales, sean determinantes en la conformación de las prácticas de lectura y sus repercusiones no sólo incumben al proceso pedagógico sino también a la producción de modelos culturales, económicos y políticos.

Dado lo anterior consideramos oportuno orientar el propósito de este primer Seminario a conocer los ángulos que nos aportan las diferentes miradas sobre el tema de la lectura, provenientes del estudio, la reflexión y las diversas experiencias que existen al respecto. Con este ánimo se procuró formar no sólo un grupo plural de narradores sino también de escuchas en diferentes áreas del conocimiento y ámbitos de acción. Todo esto con el fin de comprender la historia, conocer el presente y tratar de vislumbrar el futuro de la lectura. 


\section{ANTECEDENTES DEL SEMINARIO}

Decíamos que el estudio de la lectura es un tema del cual ya no sólo se ocupa la pedagogía; hoy encontramos abordajes que parten desde perspectivas históricas, antropológicas, sociológicas, psicológicas, lingüísticas, psicoanalíticas, etcétera. En el caso de la bibliotecología la lectura también ha sido incorporada al trabajo de investigación.

En el Centro Universitario de Investigaciones Bibliotecológicas (CUIB) de la UNAM, sede de este Seminario, pocos años después de su creación, en 1981, una de las investigadoras fundadoras del Centro, María Trinidad Román Haza, después de concluir una investigación sobre usuarios, encontró que uno de los problemas más frecuentes entre las comunidades universitarias estudiadas era la poca dedicación a la lectura fuera de las horas destinadas a los textos obligatorios. De sus indagaciones y reflexiones le surgió una pregunta: ¿qué factores desarrollan la avidez por la lectura, o, por el contrario, el desagrado por esa actividad? A partir de esta duda propuso que la lectura se constituyera en una línea de investigación, objetivo que fue aceptado de inmediato en 1986. Por ello el CUIB puede considerarse como institución pionera en el estudio formal de la lectura dentro del campo de la bibliotecología. Este acontecimiento permitió posteriormente abrir nuevas temáticas dentro de esta línea, entre las cuales se encuentran la teoría de la lectura, la historia de la lectura en México y las prácticas de la lectura en la sociedad contemporánea. En la actualidad estos temas constituyen proyectos individuales.

Por otra parte la vinculación del CUIB con la educación bibliotecológica facilita que los investigadores dedicados al tema trasladen a las aulas las problemáticas sobre la lectura y las articulen con la teoría y la práctica bibliotecológicas. Esta circunstancia ha favorecido el incremento de tesis de licenciatura y postgrado sobre el tema, lo que equivale a decir que existe una creciente atención por estudiar la participación que tiene la bibliotecología, en especial, en el fomento a la lectura.

Resultado de la articulación entre investigación-docencia fue la creación de la asignatura Lectores, lectura y bibliotecas en el Colegio de Bibliotecología de la Facultad de Filosofía y Letras de la UNAM. 
Esta acción fue parte de la reforma al plan de estudios de la carrera de bibliotecología, iniciativa apoyada por el doctor Filiberto Felipe Martínez Arellano, actual director del CUIB, entonces coordinador del citado Colegio. Tuve la oportunidad de elaborar la propuesta del programa de la asignatura para ser sometida al Comité Académico, cuyas observaciones y sugerencias enriquecieron el programa. Esta asignatura empezó a impartirse por primera vez en el año 2003.

En cuanto al postgrado de Bibliotecología y Estudios de la Información, también de la Facultad antes mencionada y el CUIB, desde sus inicios, en el año 2000, aquél incorporó en el plan de estudios el Seminario de Comunicación y Lectura. Muy posiblemente las nuevas generaciones de bibliotecólogos, al adentrarse en el conocimiento de las problemáticas de la lectura, se interesen por la investigación teórica y aplicada además de participar en la solución de problemas y aportar alternativas que coadyuven a una mejor articulación de la actividad bibliotecológica en políticas y acciones que incidan en la relación entre lectura y sociedad.

Aparte de la investigación y la docencia, el CUIB lleva a cabo distintas reuniones de especialistas interesados en el intercambio, discusión de problemas y también la difusión de resultados de investigación, experiencias y reflexiones sobre las problemáticas estudiadas mediante coloquios, conferencias, mesas redondas y seminarios. Por tal motivo hemos propuesto el Seminario sobre Lectura con la finalidad de crear un espacio destinado a la reflexión y el debate, además de compartir preguntas y hallazgos sobre los enigmas a los que nos enfrenta su estudio.

\section{PASADO, PRESENTE Y FUTURO DE LA LECTURA}

Nuestros discursos y nuestros actos, están por lo regular apoyados o son consecuencia de nuestra historia personal, familiar, social inmediata o lejana; por otro lado el deseo, la esperanza y la utopía nos acompañan también en cada paso que damos, por ello concuerdo con Robert Darnton, especialista en el ciclo de la comunicación impresa, cuando señala la conveniencia de "[...]tratar de entender el futuro a 
través del estudio del pretérito". ${ }^{1}$ Precisamente éste fue el interés que me llevó a incluir este tiempo en el Seminario.

El pasado de la lectura es uno de los temas que hoy cobra especial interés ante las interrogantes de un presente en proceso de cambio y un futuro con más incertidumbres que certezas. En efecto, el hecho de haber estado acompañados durante siglos por el libro, tan arraigado a nuestra cotidianidad, nos da la certidumbre de que la lectura textual no tiene otro continente más que el propio libro.

Pero la llegada de la tecnología digital ha resultado inquietante para muchos, en tanto ha creado para otros ilusiones exaltadas más por la fantasía que por las posibilidades de la tecnología que hicieron parecer anacrónico todo aquello que no fuera digital, entre ellos los libros impresos. No pocos sintieron temor por la desaparición de este entrañable objeto que es el libro y su carga simbólica, con respecto a la cual desarrollamos prácticas, gestos y metáforas. Posiblemente sea ésa una de las razones que despierta el deseo de asir los objetos, las prácticas, las creencias; es decir, aquellos referentes con los cuales nos constituimos como sujetos lectores. Ante este hecho hoy necesitamos buscar respuestas en las huellas dejadas por los pueblos orales y preguntarnos qué les sucedió cuando la palabra escrita apreció en su escenario. O bien cuestionar los cambios que produjo la imprenta en aquellas sociedades que eran todavía orales y a las pocas que eran lectoras de libros manuscritos. Nos inquieta tanto el futuro que nos dedicamos a fundamentar la existencia y permanencia del libro y a partir de él, nuestro ser lector. La atención por el pasado puede deberse a lo señalado por Ivan Ilich, que sea éste el momento propicio para cultivar una variedad de enfoques, "porque el libro ha dejado de ser la metáfora raíz de esta época". ${ }^{2}$

1 Robert Darnton. El coloquio de los lectores: ensayos, sobre autores, manuscritos, editores y lectores. México: Fondo de Cultura Económica, 2003. p. 155.

2 Ivan Ilich. En el viñedo del texto. Etología de la lectura: un comentario al "Didascalicon" de Hugo de San Victor. México: FCE, 2002. pp. 9-10. 
En el presente las generaciones que logramos cruzar la barrera del tiempo y nos encontramos en el siglo XXI sabemos que el libro, como señala Chartier, "ya no ejerce más el poder que ha sido suyo, ya no es más el amo de nuestros razonamientos o de nuestros sentimientos frente a los nuevos medios de información y comunicación de que a partir de ahora disponemos". ${ }^{3} \mathrm{El}$ inicio de una nueva era, además del invento de los sistemas electrónicos de información y el desarrollo de la telecomunicación produjeron ideas futuristas, en parte por el poco conocimiento y dominio que aun teníamos sobre la nueva tecnología, pero a la vez porque la fantasía suele rebasar la realidad. Así entonces la tecnología formó parte de temas en los argumentos literarios como el 1984 de Orwell o películas como 2001 Odisea del espacio, de Kubrick. Nuestra disciplina no escapó a esos pronósticos, aún recordamos el impacto del libro Sociedad sin papel de Lancaster o, en el terreno sociológico, La aldea global de McLuhan.

Hoy aseguramos que el libro sobrevivirá. Más aún, afirmamos que el placer de la lectura únicamente puede ser posible en los libros pero no en la pantalla, aunque no negamos que ésta tenga su encanto. Pero la amenaza está dirigida al lector, se insiste en que la gente ya no lee y menos aún por gusto, que la gente no sabe leer, y ahora se culpa a la escuela. Pero no consideramos otros factores, como los políticos, económicos y de comunicación, que hoy sabemos que modelan y remodelan la conformación de las prácticas de lectura y de los públicos lectores. Para argumentar lo anterior, replicamos cifras que provienen de fuentes dudosas, porque no tenemos otras, exaltamos las virtudes de la lectura y del libro y les asignamos poderes para transformar por sí mismas a los individuos y a sociedades enteras. ¿Pero en qué fundamentamos las virtudes de la lectura y una serie de afirmaciones que sostienen que para saber basta con leer libros, muchos libros? Es más, implícitamente aludimos a un lector ideal cuando describimos al no

3 Roger Chartier. Sociedad y escritura en la edad moderna. México: Instituto Mora, 1995. p. 249 
lector. No acabamos de saber si esa nostalgia del lector ideal perdido existió antes; es decir, si el número de lectores por gusto fue mayor antes que en la actualidad, y si las destrezas lectoras de las generaciones anteriores a la televisión eran superiores a las de las actuales.

Recientemente los resultados del estudio PISA 2000 y 2003, conmocionaron a aquellos países cuyos jóvenes fueron ubicados en una tercera categoría por deficiencias en sus habilidades para leer, escribir y comprender lo leído. Situación de la que no quedaron exentos países desarrollados poseedores de una larga tradición cultural, educativa, editorial y bibliotecaria, además de índices mínimos de analfabetismo y una población que ha superado el nivel básico de educación.

Ahora descubrimos que no basta con enseñar las destrezas para leer y escribir, que la lectura es una actividad compleja y no una responsabilidad exclusiva de la escuela. Lo cual nos lleva a problematizar el fenómeno de la lectura, actividad de la cual se pensaba que todo estaba ya dicho. Hoy por fortuna surgen cada vez más preguntas sobre qué es la lectura, cómo advenimos sujetos lectores, qué significa ser lector, y cuáles fueron los usos de la lectura para diferentes épocas, culturas e ideologías. ¿Con qué y cómo armamos un paradigma fundado menos sobre creencias y más en fundamentos humanísticos, en especial hoy que el gobierno global ha puesto la lectura sobre la mesa de discusión?

El futuro ya nos alcanzó, como decíamos anteriormente, felizmente comprobamos que una buena parte de las predicciones en torno a la muerte del libro impreso, y con él todo un sistema cultural, no se ha hecho realidad. Sin embargo no podemos negar que están produciéndose transformaciones importantes, a tal grado que el nuevo modelo social basado en la tecnología electrónica reconfigura nuestro sistema social de comunicación y a la vez las prácticas sociales, entre ellas las relacionadas con la lectura, y el acceso, la producción y el uso de la información. Incluso la textualidad electrónica empieza a dominar en algunos ámbitos como los académicos y científicos en donde el medio digital substituye al impreso con productos más eficientes además de atractivos y capaces de localizar rápidamente información precisa, confiable y actualizada. 
Por otra parte, cada vez es mayor la presión por hacer que los ciudadanos del futuro ingresen a un nuevo modelo cultural de lectura y consumo de libros y de información digital. Me refiero a aquello que se encuentra implícito en los criterios establecidos por la OCDE relacionados con las destrezas de lectura, las cuales aluden al lector ideal. La amenaza que se cierne para quienes tengan deficiencias para leer y escribir (las destrezas determinadas por ese organismo), no serán personas aptas para vivir conforme a las exigencias de la denominada Sociedad de la Información. Esta circunstancia merece un análisis crítico que nos ayude a derivar una propuesta más humanística que utilitaria.

\section{DE LOS PONENTES Y SUS CONTRIBUCIONES}

Esta memoria reúne los trabajos presentados en el Seminario de Lectura: pasado, presente y futuro celebrado en la sede del Centro Universitario de Investigaciones Bibliotecológicas (CUIB) de la UNAM del 29 de septiembre al 2 de octubre de 2003. La organización de las ponencias guarda un orden diferente al programa del Seminario, pues la finalidad de esta memoria es proponer una trayectoria de lectura de estos textos que nos conduzca de los tópicos particulares hacia los de naturaleza más teórica. Desde luego cada lector hará uso de su derecho de seleccionar el orden que responda a sus intereses.

Iniciamos con el trabajo de Felipe F. Martínez Arellano a manera de introducción, quien tiene la representación de la institución que nos acoge. Seguimos con Michèle Petit El extraño objeto que nos reú$n e$, título que además de evocar el deseo que nos mantuvo juntos en el Seminario, también nos introduce en el proceso interno afectivo del sujeto durante el surgimiento del deseo de lectura. El control en la orientación de la lectura, de Juan Ros García, nos indica algunos factores presentes en el lector relacionados con la autoridad, la cual favorece o impone determinadas actitudes y prácticas de lectura. Tres apostillas al libro ¿Qué leen los que no leen? Sobre la mitología bienintencionada de la lectura, de Juan Domingo Argüelles, nos presenta los mitos sobre los que se cimientan algunas creencias y 
prácticas lectoras. En La lectura en los tiempos de Internet, Elsa Ramírez Leyva presenta algunos atisbos acerca de los cambios que están surgiendo en la valoración sobre los modelos digitales en el contexto de la Sociedad de la Información. Pasado, presente y futuro de la lectura: algunos dilemas desde el punto de vista de un editor de Daniel Goldin, identifica las tensiones económicas, políticas y éticas que existen en torno de la lectura. Investigación de la lectura en Alemania. Métodos y resultados, de Christine Garbe, nos ofrece un aspecto teórico metodológico del tema y su aplicación para problematizar, analizar y explicar problemas de diferente naturaleza. En Allende los linderos. Hacia la integración de enfoques en los estudios de la lectura y la escritura, y en De la lectura y la escritura y sus relaciones con la política: algunas perspectivas de comprensión desde los lenguajes políticos, ambos trabajos de Didier Álvarez Zapata, se nos plantean propuestas teórico metodológicas interdisciplinarias, además de un análisis de factores poco analizados relacionados con la conformación de representaciones y prácticas sociales de la lectura. Concluimos con el trabajo de Noé Jitrik, El lector. Ser o no ser, cuyo título por sí mismo enuncia la naturaleza de su contenido y el que más que cerrar el tema del coloquio abre toda una reflexión para estudiar el pasado, mirar de modo diferente el presente y ampliar el horizonte del estudio del fenómeno de la lectura.

Las conclusiones que a continuación se presentan fueron hiladas de manera espontánea por Jitrik en el cierre del seminario. Al retomar la presentación de Didier y comentar que se establecen dos campos de trabajo posibles, uno relacionado con el objeto de la lectura y el otro relacionado con el uso de ese objeto, Didier se inclina por el uso de ese objeto; es decir, entiende a la lectura como un determinado campo teórico y conceptual manipulable para justificar lo cual invocó una serie de elementos de reflexión bibliográfica y del ámbito bibliotecológico que le parecieron oportunos. Además la mayor parte de la exposición de Didier tuvo que ver con los usos tanto efectivos como reales de la sociedad y también los usos posibles, utópicos e incluso los deseables. 
Por su parte, Jitrik marcó una diferencia respecto de lo anterior y planteó ser escéptico respecto a que el objeto de lectura, y por añadidura el lector, sean relativamente conocidos, además de sostener que éstos tienen una cantidad de incógnitas y misterios que no se han terminado de aclarar. Sugirió crear una línea de trabajo posible para que los cursos deseables puedan tener un mayor sustento, lo cual es necesario para acercarse a esos misterios.

Comentó luego que la dimensión crítica es la catapulta para llegar a la idea de la lectura como construcción del sentido, porque esa lectura percibe o formula el sentido que ésta tiene en tanto que las otras se hacen sin asumir esa dimensión. Así, el tipo de lectura crítica se entendería como el de aquél que llegó a ella y la entiende. Al llegar a este nivel habría entendido qué es la lectura en tanto actividad humana y comprendería el papel que desempeña la letra como forma de inscripción así como el paso de lo inconsciente a lo consciente, formulado en la letra como forma, como objeto creado que a la vez también puede ser humano y que permite esas conexiones.

El Seminario terminó con la participación de una joven asistente a quien podríamos asignarle la función de representante de la nueva generación, porque lanzó la siguiente reflexión: “ahora existen más posibilidades de lectura porque en una computadora tenemos acceso a miles de libros". Sin duda su comentario nos invitaba a proseguir con el Seminario. Pero el tiempo es implacable, quizás en algún seminario futuro reanudemos nuestras narraciones y reflexiones sobre este comentario que quedó sin respuesta, así como muchos otros que surgieran de la lectura de estos trabajos.

Al final de la memoria podrán consultar la vida académica de cada uno de los autores que participaron en este primer Seminario de Lectura. Esperamos que el encuentro de los lectores y los textos de esta memoria, con respecto a este objeto de deseo: saber de la lectura, nos una más allá del tiempo y del espacio. 
La contribución del CUIB a la investigación de la lectura de Filiberto F. Martínez Arellano

En la primera parte del texto, Felipe Martínez aborda la importancia que tiene la lectura para el modelo educativo, cultural y en la sociedad en general. En la segunda presenta un panorama retrospectivo del trabajo de investigación realizado por el Centro Universitario de Investigaciones Bibliotecológicas sobre el tema de la lectura. El conjunto de las investigaciones, sostiene, expresa las problemáticas metodológicas, históricas y sociales de la lectura y los lectores. Además, Felipe Martínez presenta una extensa recopilación de los productos editoriales derivados de estas investigaciones. Menciona también las temáticas particulares surgidas en debates, encuentros, coloquios, y los tópicos presentes en la actividad docente del CUIB. Esta amplia trayectoria nos permite apreciar la amplitud y complejidad del fenómeno de la lectura.

\section{El extraño objeto que nos reúne de Michèle Petit}

Su texto nos introduce en el contexto privado del lector, pero no sólo aborda un segmento espacio-temporal determinado, sino que, con base en un andamiaje psicoanalítico, nos acerca a esos otros elementos que conforman los antecedentes de la historia que determina la formación del sujeto lector, como son los procesos de transmisión y apropiación de la lectura en nuestras sociedades. El lector es un sujeto que construye su historia apoyándose en fragmentos de relatos y frases escritas por otros, de las que obtiene fuerza para seguir a veces otro camino distinto al cual todo parecía destinarlo.

Con su propuesta Petit busca aproximarnos a aquellos que buscan alcanzar el lector a través de los libros. Con ese fin, identifica lo que está en juego, la relación entre un mediador, un niño o un adolescente, y un libro. Asimismo rescata las lecturas discretas o secretas, cuya importancia es a menudo desconocida o subestimada. Para ello, deja deliberadamente de lado los usos inmediatos de la lectura. Su propuesta busca esclarecer un porvenir para la lectura, algo que está en juego con la democratización de ésta, y el margen de maniobra que tienen los mediadores así como las dificultades de su posición. Plantea 
también algunas otras respuestas a preguntas que hoy son fundamentales:

- ¿Cómo se vuelve uno lector?

- ¿Cómo le viene el gusto por la lectura a un chico o a una chica en su familia?

- ¿Qué pasa cuando un chico o una chica, ve a su madre o a su padre leyendo?

En cuanto a los mediadores, señala la función que tiene la biblioteca como un espacio privilegiado para establecer una relación con el libro que no se fundamente en las perspectivas utilitaristas de la instrucción. Se trata más bien de crear tiempos y espacios destinados a la fantasía, de los cuales no debemos rendirle cuenta a nadie. Espacios y tiempos en donde se forja el sujeto y que, tanto como los aprendizajes, ayudan a crecer y, sencillamente, a vivir. Afirma que lo decisivo de la lectura de los libros de hoy lleva a cada persona, mucho más que en el pasado, a construir su propia identidad y el sentido de su vida.

Sobre la mitología bienintencionada de la lectura. Tres apostillas al libro ¿Qué leen los que no leen? de Juan Domingo Argüelles

Argüelles construye sus apostillas a partir de respuestas a los comentarios de los lectores de su libro ¿Qué leen los que no leen? La primera la destina a la pregunta ¿afición o bábito? para lo cual se apoya en la obra La lectura, eafición o bábito? de Luis Arizaleta y Antonio Ventura. En su análisis estos autores plantean una crítica a una serie de aseveraciones y frases sobre el hábito idealizado de la lectura, que poco se reflejan en las prácticas y por tanto producen confusión en el niño y el adolescente en relación con el discurso sobre el gusto por leer "como debemos".

La siguiente apostilla Argüelles la destina al tema de la desescolarización de la lectura, tema que hoy está en debate debido a que la formación de lectores ha dejado entrever el problema de los sistemas pedagógicos que han hecho de la lectura una actividad obligatoria y utilitaria. Es decir, la lectura en la escuela resulta formativa pero no 
garantiza el convencimiento de los lectores sobre los beneficios de esta actividad. El autor manifiesta su punto de vista acerca de los problemas derivados de la poca participación escolar y de una cultura donde el placer de la lectura parece desdeñarse. Otro aspecto abordado es el doble discurso sobre los beneficios de la lectura, cuando en la realidad el ciudadano exitoso que la sociedad de hoy privilegia no es precisamente el ideal de lector presente en los discursos de los intelectuales y los políticos.

En su tercera apostilla Los beneficios culturales de los no lectores, Argüelles presenta un debate en torno a las sociedades en las que una porción amplia de la sociedad no es lectora aunque esté alfabetizada y cuente con niveles superiores de educación. Argüelles propone un discurso donde la invitación al lector está basada en bases reales y no idealizadas, menos dogmáticas, más tolerantes, y más cordiales.

\section{El control en la orientación de la lectura de Juan Ros García}

Juan Ros polemiza sobre el tema de la libertad y el control en la lectura. Un tema que podría pensarse superado en las sociedades democráticas del siglo $X X$ y del presente siglo. Algunas de sus preguntas: ¿Qué es control? ¿Qué es orientación? ¿Debe haber control en la orientación de la lectura? Y, si es así ¿Quién la debe ejercer? ¿Qué ha ocurrido hasta ahora? ¿Qué debe leer un niño? ¿ Y qué debe leer un adulto? Ante ello, la tensión entre las posturas de controlarlo todo o no controlar nada es permanente. Para emprender está problemática Ros presenta una revisión histórica intentando demostrar los mecanismos de control que tienen los sistemas de poder sobre las libertades de los individuos en cuanto a la lectura.

Aborda también el tema de censura que ha tomado diferentes modalidades y no ha sido privativo, en absoluto, de los periodos medievales. En pleno siglo XX y XXI, la censura está presente evidente o subrepticiamente, mediante leyes que reglamentan los derechos y la conformación de colecciones, con lo cual una biblioteca puede menguar su oferta de lectura. Por otra parte determinadas casas editoras colocan en el mercado títulos a precios muy accesibles. También, 
sostiene Ros, que las formas de evaluación, publicidad y distribución pueden orientar a los ciudadanos hacia determinadas lecturas.

\section{Investigación de la lectura en Alemania. Métodos y resultados de Christine Garbe}

Su contribución queda integrada en tres partes. La primera, destinada a un estado del arte de la investigación de la lectura en Alemania, inicia con una introducción que explica el cambio de orientación metodológica basado en el paradigma de socialización fundamentado en la teoría del mismo nombre. A partir de los años setenta los investigadores alemanes proponen una perspectiva de la lectura diferente al enfoque pedagógico que hasta entonces había dominado. Este enfoque se consolida diez años después y su paradigma es adoptado tanto en el ámbito de la sociología como en el de la ciencia educativa. Esta corriente busca analizar y explicar las influencias intencionales y las condiciones no intencionales mediante las cuales el sujeto es capacitado para convertirse en miembro de un orden social establecido. Asimismo menciona otra de las corrientes importantes que buscan una nueva concepción del sujeto lector, la psicología cognitiva, que en el campo literario ha proporcionado elementos para teorizar sobre las construcciones de significados subjetivos que se producen en el proceso de lectura. Esta introducción sirve de marco para presentar las diferentes investigaciones sobre la lectura que se han venido desarrollando en Alemania.

La segunda parte la destina a la presentación de los resultados del análisis y problematiza el Estudio Pisa de la OCDE, realizado para evaluar algunas destrezas básicas, entre otras la lectura en jóvenes de 15 y 16 años. Para ello los investigadores alemanes se basaron en las perspectivas teóricas mencionadas, alarmados por el dato de que $42 \%$ de sus jóvenes declararon no leer por gusto. Entre las observaciones al Estudio Pisa, Garbe señala la excesiva orientación funcionalista, basada en la noción de "buen procesador de información", la "capacidad para leer de forma estratégica referida a tareas y objetivos", y la exigencia de poseer competencias metacognitivas. Las reflexiones en torno al Estudio Pisa han empezado a gestar fundamentos 
para construir un concepto de lector más amplio y que involucre no sólo las destrezas sino también el proceso de socialización y la didáctica de la lectura. Nos señala que las prácticas de lectura son resultado de un proceso social y que su complejidad está dada precisamente por los diferentes medios de socialización.

La última parte de su trabajo interpreta el resultado de la investigación biográfica que realizó y en la que se planteó buscar respuesta a la pregunta ¿de qué depende el proceso de adquisición de competencia sobre la lectura, de contextos sociales que lo apoyen? Los resultados de la investigación llevada a cabo por la propia Garbe y otros investigadores les permitieron identificar elementos motivacionales que pueden ser transferidos al ámbito escolar. Los resultados muestran la importancia que tiene la diferenciación de género y generacional, y la que adquieren otros factores como la motivación y los medios de socialización.

La ponencia de Garbe nos abre una perspectiva teórica con la cual podemos problematizar diferentes aspectos de la lectura, tanto particulares como de grupos o culturas, a la vez que enfrentar el fenómeno de la globalización de la lectura. También propone alternativas para los diferentes ámbitos que influyan socialmente en el individuo.

\section{La lectura en los tiempos de Internet de Elsa M. Ramírez}

\section{Leyva}

La ponencia basa su análisis en la teoría de la representación y las prácticas sociales de Moscovici, e identifica y explica aquellos factores que modifican las prácticas de lectura que pone en juego la sociedad contemporánea de la información, como los anteriores modelos sociales que construyeron sus propios medios y formas de representación. En la actualidad la sociedad empieza a construir un nuevo tipo de lector que participa en los sistemas pedagógicos, en los programas de promoción de la lectura y en los contenidos de los medios de comunicación.

Su texto está estructurado en dos partes, la primera describe las condiciones actuales capaces de modificar las prácticas sociales de lectura; la segunda explica algunos de los resultados del estudio 
realizado sobre el impacto que ha producido Internet en las prácticas de lectura e informativas en la comunidad académica de la UNAM.

Concluye con la reflexión sobre la importancia de conocer las condiciones de la bibliotecología en cuanto a su participación en la formación de las prácticas de lectura e informativas. Asimismo menciona la necesidad de estudiar los efectos de Internet en un contexto en donde este medio empieza a constituirse en un emblema de la sociedad del Siglo XXI, con el propósito de revisar el discurso bibliotecológico y así fundamentar las prácticas bibliotecarias para buscar un equilibrio entre la lectura formativa, la informativa y la estética.

\section{Pasado, presente y futuro de la lectura: algunos dilemas desde el punto de vista de un editor de Daniel Goldin}

$\mathrm{Su}$ texto aborda los fundamentos que respaldan los criterios que pretenden tener una validez general y los programas futuros de lectura. Goldin ubica dos posiciones, una optimista producida por escasos triunfos aislados que tienen pocas posibilidades de generalización, pues parten de bases endebles; la otra es fatalista y oscura, y se basa en el desconocimiento y programas que fracasan por apoyarse en compromisos temporales. Goldin toca problemas de fondo y cuestiona críticamente conceptos y categorías en apariencia claros y unívocos.

A la vez, Goldin observa un doble conflicto entre dos libertades que al elegir o rechazar, al aceptar o modificar, posibilitan o clausuran formas de ser lector o editor, que a su vez están condicionadas por otros factores internos y externos al ámbito de la producción y circulación de la palabra escrita, sobre todo cuando se pretende abordar el problema de manera procesal, en ciclos más o menos largos.

Goldin cuestiona por qué en un mundo en el que paradójicamente los hombres estamos cada vez más comunicados, sin embargo estamos más aislados. Otra cuestión la dirige a los editores, quienes tendrían que preguntarse sobre su concepción y su participación en la formación de lectores, pero no sólo como un asunto de principios, sino también en relación con su racionalidad empresarial; es decir tendrían que analizar cuál es su capital y dónde convendría invertir para obtener mejores resultados económicos. 
También plantea otras preguntas: ¿Es cierto que cada vez hay menos lectores? ¿Se debe esto al auge del Internet, al desarrollo de los medios masivos, o al deterioro de la educación? La supuesta reducción de lectores debida al auge de los medios es una afirmación muy discutible (y poco discutida), incluso en términos meramente estadísticos. Cuando en México no tenemos una encuesta nacional de lectura e instrumentos para juzgar la evolución de las conductas lectoras en términos cuantitativos, Goldin sostiene que son aproximaciones, y por lo mismo propone que la investigación sociológica y antropológica aporta elementos para formar más y mejores lectores como un modo de equilibrar incluso el discurso mercadotécnico, pues en su opinión es indispensable aceptar la realidad del mercado.

Allende los linderos. Hacia la integración de enfoques en los estudios de la lectura y la escritura y de la lectura y la escritura y sus relaciones con la política: algunas perspectivas de comprensión desde los lenguajes políticos de Didier Álvarez Zapata

Didier Álvarez presentó su trabajo en dos partes. En la primera fundamentó su propuesta de un enfoque integral para analizar, comprender y explicar las representaciones de la lectura y la escritura como prácticas sociales, culturales y políticas. Su enfoque busca alternativas alejadas de concepciones que instrumentalizan e incluso simplifican la complejidad de la lectura y de la escritura al limitarlas a competencias y habilidades comprensivas que eluden una perspectiva sociocultural y política. Considera que la complejidad del estudio de la lectura y la escritura las torna objetos de estudio transdisciplinares, lo cual implicaría renovar tanto los discursos como las metodologías de investigación. Además conduciría a reconfigurar la bibliotecología y la ciencia de la información a fin de tener una comprensión más clara de sus responsabilidades culturales, sociales y políticas.

Álvarez identifica dos posturas en juego: aquellas que consideran que la lectura y la escritura son dos actividades importantes, además de necesarias, pero sobre las cuales hay poco que preguntarse y mucho menos algo que decir. Y esas otras que, por el contrario, sobredi- 
mensionan la lectura y la escritura, y basan en ellas el desarrollo social; una suerte de piedra angular para la superación de la ignorancia; es decir, la panacea que puede resolver casi todos lo problemas sociales.

Didier Álvarez observa en el estudio de la lectura y la escritura dos caras, y alude a la metáfora de la moneda: de un lado ubica la lingüística cerca de la psicolingüística, que se aboca a los procesos de formación e integración del pensamiento y el lenguaje, en la línea de construcción de la significación. Del otro lado una cara menos evidente, menos elaborada: los factores determinantes, las consecuencias socioculturales además de políticas de la lectura y la escritura en una sociedad particular. Por tanto una sola disciplina aportaría conocimientos fragmentados, puesto que esas dos actividades están sometidas a las actuales variaciones del horizonte espacio-temporal desde el cual tanto hombres como mujeres ven y quieren ver el mundo.

Esta crisis de la sociedad contemporánea a la que se refiere Didier obedece a los efectos de la tecnología textual y a mutaciones surgidas en las prácticas de lectura y escritura, y para solucionarla propone investigaciones transdisciplinarias con enfoques integrados de los saberes de la antropología cultural, la sociología, la historia, las ciencias de la comunicación y de la información, y la politología.

En suma la propuesta de Álvarez Zapata es conjuntar los saberes de aquellas disciplinas que aportan fundamentos para interpretar los múltiples y sinuosos senderos por los que transitan hoy las prácticas de lectura y escritura.

En su segunda ponencia De la lectura y la escritura y sus relaciones con la política: algunas perspectivas de comprensión desde los lenguajes políticos, Álvarez propone, apoyado en las ideas de Paulo Freire, salir de los límites tradicionales de abordaje de lectura y escritura, para considerarlas como prácticas de orden político. Con base en ello problematiza el proceso de aspectos como la aceptación de la dominación; la integración política; la legitimación de los sistemas políticos; las prácticas culturales y sociales (entre ellas la lectura y la escritura); la presencia pública de los sujetos; la conformación e integración ideológica y funcional de los ámbitos privado y público; la formación de opinión pública (de central interés actualmente) más 
la formación ciudadana entendida como ámbito de integración de ideales educativos políticos dentro de cierta cultura política y como despliegue de propuestas pedagógicas.

Álvarez identifica la consecuencia de los discursos políticos basándose en su tesis de que ejercen un control social y político. Es decir, la lectura y la escritura son utilizadas para la reproducción misma del sistema. Así, en el panorama de los discursos políticos que sobre la lectura se han tejido, analiza tres discursos: el discurso funcionalista liberal, el discurso republicano y el discurso crítico emancipatorio.

El Lector: Ser o no ser de Noé Jitrik

La ponencia de Jitrik nos coloca frente a una cuestión compleja, a la vez profunda sobre SER LECTOR. Precisamente su texto abre con la pregunta ¿Qué es ser lector? Las respuestas hasta ahora desarrolladas al respecto son aproximaciones más por descripción que por definición. El problema que creemos entender en lo expuesto por Jitrik, parece condicionar la existencia del lector como consecuencia de la existencia de los objetos hechos para leer, negando así su existencia anterior e incluso futura en el caso de que estos libros desaparezcan. Es decir un lector sin "un ser" está más expuesto a ser modelado y remodelado conforme a las condiciones de un orden político y económico, mediante políticas de lectura explícitas o implícitas en los procesos pedagógicos, culturales, bibliotecológicos, editoriales.

Jitrik propone repensar el ser lector en dos órdenes, uno crítico pero también descriptivo acerca del lector de hoy, y otro propositivo, dirigido a aumentar la forma posible del lector ideal.

La propuesta de Jitrik es sin duda compleja, pero precisamente hoy que se habla tanto del cambio del perfil del lector actual, al que se intenta homologar a la forma de la cultura de hoy, nos ofrece la oportunidad de llevar a cabo un análisis crítico de su configuración así como de su significación con el fin de desarrollar una respuesta y una propuesta humanista frente a las potencias tecnológicas y económicas ante la posible deshumanización de nuestra civilización. 


\title{
La contribución del CUIB a la investigación de la lectura
}

\author{
Filiberto Felipe MarTínez Arellano
}

\begin{abstract}
1 hacer referencia a la lectura es posible hacer mención a una - famosa frase de Albert Einstein que puede ser utilizada para ilustrar el papel y la importancia que ésta juega en el desarrollo de las capacidades de los seres humanos: "La imaginación es más importante que el conocimiento."
\end{abstract}

\section{IMPORTANCIA DE LA LECTURA}

Sin duda alguna el libro ha sido a lo largo de la historia un instrumento de primer orden para transmitir conocimientos; sin embargo su principal atributo es quizás ser un promotor de la imaginación (Cmetmedia.com, 2003):

La lectura es importante no sólo a la hora de estudiar, también estimula la creatividad, relaja y permite conocer realidades distintas y lejanas. Los especialistas señalan que para el desarrollo de los niños es una necesidad esencial, ya que ellos se encuentran en etapa de pleno aprendizaje, pero en los adultos este hábito también es fundamental ya que los ayuda a diversificar sus puntos de vista respecto del mundo que los rodea, a ser más analíticos y a entender procesos y no sólo hechos aislados.

Ciertamente una de las capacidades de los individuos que la lectura fortalece es el desarrollo de la imaginación y el siguiente texto ilustra la importancia de este acto (El bábito de leer, 2003):

El hombre que no ha tenido el hábito de leer está prisionero en su mundo inmediato en cuanto a tiempo y espacio. Su vida cae dentro de una rutina establecida; se limita al contacto y la conversación con algunos amigos y conocidos, y no ve más de lo que sucede en su vecindad. De esta prisión no hay fuga posible. 
Pero en el momento en que se toma un libro entra en un mundo distinto, y si se trata de un buen libro, inmediatamente entra en contacto con uno de los mejores charlistas del mundo. Este charlista lo guía y lo conduce a una nación diferente o a una época distinta, descarga en él algunos de sus remordimientos personales, o lo invita a discutir algún tema especial o un aspecto de la vida de la que el lector nada conoce.

Un autor antiguo lo pone en comunión con un espíritu desaparecido hace muchos años y según el lector avanza, comienza a imaginar la apariencia y el tipo de persona que era el escritor.

Por lo tanto, poder vivir un par de horas en un mundo y alejar nuestros pensamientos de las exigencias del presente inmediato, es un privilegio que deben envidiar aquellos que se encuentran presos en sus cárceles corporales.

No obstante su importancia para el desarrollo educativo e intelectual de los individuos, la lectura se enfrenta en nuestros días a una creciente ola de imágenes y de representaciones visuales. Diariamente observamos cómo la televisión y la tecnología digital influyen en el desplazamiento de la lectura puesto que estos medios técnicos de reproducción de las ideas facilitan la comunicación de mensajes breves. Sin embargo en el plano intelectual la excesiva familiaridad con las imágenes no apoya un desarrollo cognitivo, ni estimula la fantasía, ni la creatividad y deteriora la curiosidad infantil. En cambio la lectura presenta una serie de ventajas entre las cuales pueden ser mencionadas las siguientes (Literatura infantil, 2003):

- La lectura implica toda la vida psíquica, las actividades que exigen un esfuerzo movilizan toda la capacidad psíquica.

- La potencia de las facultades lógicas, el esfuerzo mental que va hermanado con la lectura.

- El enriquecimiento del patrimonio lingüístico (hablar, oír, leer y escribir).

- El espíritu crítico: la lectura de diferentes formas de pensar sobre una cosa.

- La lectura educa nuestro sentido estético.

- La lectura nutre la fantasía.

- Ensancha la imaginación.

- Cultiva el sentimiento. 
- Descubre intereses más amplios.

- Permite descubrir el silencio, aprender a estar solo.

- Ayuda a la asimilación crítica de la información.

- Ordena la realidad.

Además de las ventajas anteriormente señaladas, en un artículo irónico acerca de la lectura titulado "Razones para no leer", Vidriales (2001) señala lo siguiente:

- Leer nos cambia. Al leer no sólo es la mente la que trabaja, sino también la imaginación y la memoria, dice Felipe Garrido. Al leer, la gente hace contacto con sus instintos, con la intuición, con sus afectos. Cualquiera puede contarle los peligros que esto implica.

- Leer hace pensar. Cuando alguien lee, promueve un acto radical en el que no busca, como dijo Francis Bacon, contradecir e impugnar, ni creer y aceptar, sino pensar y considerar. Pensar es una actividad que atenta contra el orden social.

- La lectura es anárquica. Quién abre un libro entra a un terreno anárquico. Puede saltarse párrafos y avanzar a su propio ritmo. La lectura, dijo Italo Calvino, es una relación con nosotros mismos, un terreno en el que más vale no adentrarse.

- Los libros eliminan las fronteras. Luego de que la civilización ha luchado por siglos para establecer fronteras de todo tipo, los libros llegaron para borrarlas. Quien lee entra a dimensiones incontrolables para las aduanas.

- En la lectura siempre hay optimismo. Ya hace varios siglos Miguel de Cervantes lo resumía: No hay un libro tan malo que no contenga algo bueno. Quien lee corre el peligro de no estar a la altura del pesimismo que reina por todas partes.

- El libro es enemigo de la conversación. El filósofo Fenelón lo advirtió hace tiempo. Los que saben ocuparse en cualquier lectura útil y agradable, jamás sienten el tedio que devora a los demás en medio de las delicias. Quien lee, nadie lo duda, atenta contra el mayor tema de conversación: el aburrimiento.

- Leer es un placer. La lectura invita al gozo, al abandono. Es un acto egoísta y sensual. 
Tomando en consideración la importancia de la lectura como un elemento que contribuye al desarrollo educativo y cultural de los individuos y que ésta constituye un fenómeno de estudio, el Centro Universitario de Investigaciones Bibliotecológicas (CUIB) de la Universidad Nacional Autónoma de México ha llevado a cabo, a lo largo de sus veintiún años de existencia, diversos proyectos de investigación que tienen como unidad de análisis a la lectura. A continuación presento un recuento de los proyectos y acciones que el CUIB ha desarrollado en torno a esta temática.

\section{PROYECTOS Y ACCIONES EN TORNO A LA LECTURA}

Fundado en diciembre de 1981, la misión del Centro Universitario de Investigaciones Bibliotecológicas ha sido llevar a cabo un programa de investigaciones teóricas y aplicadas sobre los fenómenos relacionados con las bibliotecas, la lectura y la información. En este sentido una de las líneas de investigación que se desarrollaron a partir de su establecimiento fue "Hábitos de lectura." (UNAM..., 1993). Esta línea de investigación continuó desarrollándose durante el periodo 1993-1997 (UNAM..., 1997) con la denominación de "Lectura" y a partir de 1998 esta línea de trabajos pasó a formar parte del área "Información y sociedad." (UNAM..., 2001).

Proyectos de investigación

Los proyectos que se han desarrollado en esta línea de investigación han sido:

- El hábito de la lectura, perfil de los lectores ávidos (1985-1986). María Trinidad Román Haza

Objetivo: Indagar por qué leen las personas (lectores ávidos); es decir, cómo se volvieron lectores ávidos y qué derivan de sus lecturas. 
- Estudio de una comunidad: hábitos de lectura (1985-1992). Ana María Magaloni Gómez Rul Objetivo: Estudio vinculado al Programa Nacional de Bibliotecas Públicas de la SEP. El estudio pretendía identificar los hábitos de lectura y los intereses de la población.

- Factores que influyen en el desarrollo del gusto por leer (1987-1992).

María Trinidad Román Haza

Objetivo: Comparar las experiencias que se asocian a la lectura entre lectores ávidos, buenos lectores y no lectores, a fin de encontrar antecedentes comunes entre quienes sí leen y que precisamente están ausentes o se dan en sentido inverso en los no lectores.

- Formación de lectores (1991-1994).

María Trinidad Román Haza

Objetivo: Desarrollar el gusto por leer en los no lectores, especialmente los jóvenes.

- Evaluación del potencial biblioterapéutico de dos colecciones mexicanas de literatura infantil (1993-1994).

Carlos Christian Compton García Fuentes.

Objetivo: Estudiar si dos colecciones mexicanas de literatura infantil didáctica pueden afectar positivamente los problemas de desarrollo por ellos tratados. Crear un método para el bibliotecario escolar. Evaluar el potencial biblioterapéutico de las anteriores colecciones. Efectuar una replica del Swantic.

- La percepción del yo-mismo y la motivación para leer (19951997).

María Trinidad Román Haza.

Objetivo: Conocer cómo han sido las experiencias de lectura de personas que se podrían calificar de lectores autónomos a fin de observar, desde el enfoque de la teoría humanística, cuáles y cómo fueron los aspectos motivacionales y estimulantes que desarrollaron su gusto por leer. Analizar el fenómeno de la lectura con el objeto de identificar sus dificultades y las causas que lo motivan y así tener elementos científicos para sistematizar un plan de estimulación para menores en situación vulnerable. 
- Los efectos de la tecnología de la información en las prácticas lectoras e informativas de la sociedad mexicana y sus implicaciones en la actividad bibliotecaria: el caso de la comunidad académica de México (1999-2000).

Elsa M. Ramírez Leyva.

Objetivo: Identificar y explicar las transformaciones que causa la tecnología de la información en la comunidad académica de México en las actividades de lectura e información, y los efectos de esto en el acopio, conservación y organización de la biblioteca, y en la formación del profesional bibliotecólogo.

- La lectura y su impacto social (1999-2003). Adolfo Rodríguez Gallardo.

Objetivo: Documentar la manera en que el uso de los procesos de lectura han definido diversas tendencias en las sociedades antiguas y modernas.

- Los aspectos afectivos en la formación de los lectores, modelo teórico (1999-2002).

María Trinidad Román Haza.

Objetivo: Identificar los factores afectivos que explican el desarrollo del gusto por leer, con el fin de construir un modelo de comportamiento de estos factores en la formación de lectores.

- La lectura en la sociedad contemporánea: los efectos de la tecnología de la información en las prácticas lectoras e informativa y sus implicaciones en el sistema de conocimiento de la bibliotecología (2001-2003).

Elsa M. Ramírez Leyva.

Objetivo: Identificar los cambios que se están generando en las prácticas de lectura e informativas con el uso de la tecnología de la información en las actividades de investigación, enseñanza y aprendizaje.

- Teoría e historia de las prácticas de la lectura en México: campo bibliotecológico y práctica de la lectura (2001-2003).

Héctor Guillermo Alfaro López

Objetivo: Elaborar una teoría sobre las prácticas de la lectura que a lo largo de la historia se han dado en México, detectando con ello las contradicciones y problemáticas que éstas presentan 
para desarrollar estrategias que permitan su solución. Asimismo, se explica la relación que existe entre la práctica de la lectura y el campo bibliotecológico en nuestro país.

\section{Publicaciones}

Los resultados de los proyectos anteriormente señalados han sido plasmados en diversas publicaciones editadas por el CUIB y por otras instituciones, cito a continuación algunas de ellas:

\section{Libros y capítulos de libros}

- Magaloni, Ana María y Gayol, Yolanda. "Los hábitos de lectura de los estratos medios del Distrito Federal". En:Jornadas Mexicanas de Biblioteconomía (15 : Tlaxcala, Tlax. : 1984). Memorias. (pp. 193-216). México: Asociación Mexicana de Bibliotecarios, A. C., 1985.

Resumen: Resultado de una encuesta aplicada por teléfono a una muestra de personas del Distrito Federal seleccionadas en forma aleatoria, con el fin de conocer sus hábitos de lectura y actividades que realizan en su tiempo libre.

- Román Haza, Trinidad. "Una aproximación a la conducta lectora”. En: Edición Conmemorativa del X aniversario del Centro Universitario de Investigaciones Bibliotecológicas: t. 2, En torno a la biblioteca y sus desarrollos (pp. 19-23). México: UNAM. Centro Universitario de Investigaciones Bibliotecológicas, 1992.

Resumen: El gusto por leer no es algo que se pueda inculcar $y$, mucho menos, imponerle al estudiante, sino algo que tiene que surgir de la persona. El alumno tiene que encontrar dentro de sí sus propias motivaciones para leer y esto puede suceder si está en contacto con sus verdaderas necesidades e intereses y descubre en la lectura valores importantes que lo lleven a dirigirse hacia ella. Por lo tanto, es conveniente que el maestro favorezca la captación de valores en la conducta lectora. Se describen las cuatro condiciones que el profesor debe propiciar para que el estudiante pueda captar el valor de leer. 
- Dubovoy, Silvia. “iLeer para qué?” En: Edición Conmemorativa del $X$ aniversario del Centro Universitario de Investigaciones Bibliotecológicas: t. 2, En torno a la biblioteca y sus desarrollos (pp. 11-23). México: UNAM. Centro Universitario de Investigaciones Bibliotecológicas, 1992.

Resumen: En este artículo usted encontrará algunos aspectos interesantes referentes a la lectura: por qué el rechazo a ésta por parte de los niños, y si en una primera instancia y en forma nata les gustan y atraen los libros...

Se analizan aspectos tales como: ámbito familiar; ámbito escolar; tiempo libre y lectura; los cuidados que se deben tener con la televisión; la televisión y los libros; la necesidad de fomentar en los niños el hábito y gusto por la lectura y, por supuesto, ¿Leer para qué? que da título al artículo.

- Garduño Vargas, Sonia Araceli. La lectura y los adolescentes. México: UNAM. Centro Universitario de Investigaciones Bibliotecológicas; Colegio Nacional de Bibliotecarios, 1996.

Resumen: Define la lectura, su proceso y los tipos de ésta para enfocar lo relacionado con la lectura, la educación, las bibliotecas y el lector. Enmarca al adolescente y su mundo al mismo tiempo que define sus características y necesidades, sus intereses y sus valores. Incluye un estudio sobre la conducta lectora de los estudiantes del Colegio de Ciencias y Humanidades plantel Naucalpan. Según se estipula los resultados obtenidos (en 1993) tienen validez hasta 1995. La metodología empleada es descriptiva valorativa y se apoya en técnicas de investigación y análisis documental más la aplicación de una encuesta.

- Alfaro López, Héctor Guillermo. "Los usos de la lectura y la representación cultural: elementos para una teoría de la lectura". En: La información en el inicio de la era electrónica: v. 2, Información, sociedad y tecnología. (pp. 32-77). México: UNAM. Centro Universitario de Investigaciones Bibliotecológicas, 1998.

Resumen: Aborda los antecedentes que fueron dando lugar a las diferencias entre cultura docta y cultura popular, entre el individuo medio y el hombre excepcional, que se sale de la norma. Éste es un ejemplo de los documentados razonamientos 
(C. Ginzburg, M. Bajtin, P. Bordieu, etcétera) que desarrolla este texto histórico, rastreador, que nos lleva hasta los márgenes para ver por encima de ellos y ayudarnos a entender mucho de lo que subyace entre los términos cultura popular y cultura docta o entre las normas cultas y las normas populares.

- Román Haza, María Trinidad. "En torno a la conducta lectora". En: La información en el inicio de la era electrónica: v. 2, Información, sociedad y tecnología. (78-94). México: UNAM. Centro Universitario de Investigaciones Bibliotecológicas, 1998.

Resumen: Se aborda la lectura como un proceso complejo que ciertamente no va a desaparece con el avance de la cultura de la imagen.

- Ramírez Leyva, Elsa M. "El lector: del mundo manuscrito al cibernético". En: La información en el inicio de la era electrónica: información, sociedad y tecnología. (pp. 95-138). México: UNAM. Centro Universitario de Investigaciones Bibliotecológicas, 1998.

Resumen: Se ha llegado a decir que la escritura alfabética ha sido propiciatoria del desarrollo del mundo interno del ser humano. Bajo ese marco este texto pretende examinar el fenómeno de la tecnología de la información (la cibernética), enfocando las formas creadas y desarrolladas por el individuo para registrar, conservar, difundir y apropiarse de la memoria de la humanidad en relación con las prácticas lectoras e informativas que se han desarrollado a lo largo de la historia. Se analizan también recientes estudios sobre las innovaciones tecnológicas de la cultura impresa, los cuales permitirán comprender el actual fenómeno de la tecnología de la información en relación con la lectura.

- Encuentro Latinoamericano sobre la Biblioteca, la Lectura y el Niño Callejero (1996 : México). Memoria / compiladora María Trinidad Román Haza. México: UNAM. Centro Universitario de Investigaciones Bibliotecológicas, 1998.

Resumen: Primera reunión de su temática, en la que se plantea la problemática de la desvinculación de la biblioteca y el libro con el niño callejero en América Latina. Participaron 33 ponentes de 12 países latinoamericanos. Reunión auspiciada por la 
Federación Internacional de Asociaciones e Instituciones de Bibliotecarios (IFLA).

- Rodríguez Gallardo, Adolfo. "Por qué incluir el estudio de la lectura en la temática de los planes de estudio de las escuelas de bibliotecología”. En: Jornadas Mexicanas de Biblioteconomía (29 : Veracruz, Ver. : 1998). Memorias. (pp. 243-249). México: Asociación Mexicana de Bibliotecarios, A. C., 1998.

Resumen: Reflexiones acerca de la importancia del estudio de la lectura en los planes y programas de estudio de las escuelas de bibliotecología. Afirma el autor que el efecto de la lectura sobre el individuo puede contribuir al desarrollo de su nivel intelectual y a un cambio en sus actitudes y su comportamiento, además de considerar a la lectura como un elemento básico en el quehacer bibliotecario y un medio para poner en contacto autores y usuarios.

- Alfaro López, Héctor Guillermo. "Perspectivas de la lectura en la sociedad del conocimiento". En: Contribución al Desarrollo de la Sociedad del Conocimiento. (pp. 340-349). México: UNAM. Centro Universitario de Investigaciones Bibliotecológicas, 2000. Resumen: Trabajo presentado en el XVII Coloquio Internacional de Investigación Bibliotecológica, Contribución al Desarrollo de la Sociedad del Conocimiento. El estudio de las formas de lectura a través de la historia ha sido abordado recientemente desde una perspectiva cualitativa, por lo que conocer las formas de lectura del pasado nos ayuda a comprender las presentes y nos sirve de espejo en el que se refleja el todo, la bibliotecología. La habilidad lectora es condición necesaria tanto para la decodificación de la información y de los textos en general, como para el análisis y la comprensión de éstos, al igual que la reflexión y comprensión de lo leído son condición sine qua non para transformar la información en conocimiento, por ello la democratización de la práctica de la lectura constituye el pilar para lograr una sociedad del conocimiento. Vasconcelos y Plutarco Calles impulsaron campañas de alfabetización y democratización de la lectura buscando incorporar a México en el Nuevo Orden Mundial (NOM). En la actualidad hay que aceptar 
la coexistencia del libro con las nuevas tecnologías de la información.

- Ramírez Leyva, Elsa M. El libro y la lectura en el proceso de occidentalización de México. México: UNAM. Centro Universitario de Investigaciones Bibliotecológicas, 2001.

Resumen: La autora considera que a lo largo de la historia de la humanidad, en el objeto libro y en la lectura confluyen el desarrollo intelectual y tecnológico que se han acumulado a través del tiempo. A la vez, libro y lectura se han constituido en objetos simbólicos que se recrean conforme a la época y lugar con los cuales interactúan. De tal suerte, el libro impreso y la actividad lectora, forma y medio de la comunicación del mundo occidental, fascinaron y conquistaron al mundo indígena de México al revelarle su propia cultura como un objeto escrito en caracteres alfabéticos propios de la cultura de otro mundo. Al mismo tiempo, libro y lectura se revelan como elementos fundamentales de la entonces emergente sociedad novohispana, de la que aún prevalecen hasta nuestros días, rasgos, gestos, actitudes, costumbres e instituciones.

- Seminario sobre Lectura y Escritura Significativas para Grupos con Discapacidad Auditiva y Visual: Memoria / compiladora María Trinidad Román Haza. México: UNAM. Centro Universitario de Investigaciones Bibliotecológicas, 2001.

Resumen: Publicación emanada de la reunión de especialistas en discapacidades auditivas y visuales, cuyo objetivo era compartir experiencia y resultados de investigaciones sobre grupos de personas con estas discapacidades, que hacen uso de la lectura y escritura como herramientas para su desarrollo psicosocial.

- Román Haza, María Trinidad. "La lectura y escritura significativas para grupos con discapacidad auditiva o visual". En: Seminario sobre Lectura y Escritura Significativas para Grupos con Discapacidad Auditiva y Visual: Memoria (pp. 1-7). México: UNAM. Centro Universitario de Investigaciones Bibliotecológicas, 2001.

Resumen: Se afirma que ningún grupo debe quedar excluido de hacer uso de la lectura y escritura significativas. 
- Morales Campos, Estela, comp. Librerías infantiles: un espacio para la lectura. Mexico: UNAM. Centro Universitario de Investigaciones Bibliotecológicas; Información Científica Internacional, 2001.

Resumen: La presente obra es resultado del Seminario de Investigación Bibliotecológica que se impartió en el Postgrado de la Facultad de Filosofía y Letras de la UNAM durante el semestre 2000-2001. El texto intenta dar respuesta a una serie de interrogantes mediante una exposición colectiva sobre las distintas facetas que integran la esencia de las librerías infantiles en la Ciudad de México, y la contribución de dichos establecimientos para despertar el gusto por la lectura; también considera que la motivación de los padres en establecer un contacto amable, placentero, entre los niños y los libros, permitirá despertar el interés por la lectura desde la más temprana edad.

- Ramírez Leyva, Elsa M. "Historia y prospectiva de las bibliotecas públicas, las escolares y el hábito de la lectura: historia y situación actual”. En: Jornadas Mexicanas de Biblioteconomía (32 : Jalapa, Ver. : 2001). Memoria (pp. 308-321). México: Asociación Mexicana de Bibliotecarios, A. C., 2002.

Resumen: Después de darnos un bosquejo histórico de las bibliotecas en México, la autora insiste en el fomento a la lectura y suministra información interesante acerca del mexicano y sus hábitos de lectura. Finalmente, menciona cómo la "división digital" de Al Gore está alejando más aún a México de dicho hábito.

- Román Haza, María Trinidad La lectura en los grupos vulnerables. México: UNAM. Centro Universitario de Investigaciones Bibliotecológicas, 2002.

Resumen: Considera que la lectura para las personas que tienen necesidades especiales puede ofrecer posibilidades enormes de crecimiento y gratificación al proporcionales modelos para identificarse y que éstos sirvan para modificar sus destinos y enfrentar las situaciones de exclusión a las que por lo general están sujetas. 
- Ramírez Leyva, Elsa M. "El libro y la lectura en el proceso de occidentalización de México: Presentación dramatizada de obra". En: Bibliotecología, sociedad y cultura: el CUIB en la EXPO-UNAM 450 años. (pp. 1-20). México: UNAM. Centro Universitario de Investigaciones Bibliotecológicas, 2003.

Resumen: Representación dramatización del contenido de la obra, la cual trata de darle vida a la interpretación de una lectora acerca del sentido de la lectura, que plasmó la autora. Por ello el propósito de la representación fue recrear una de las manifestaciones de la lectura en la época en la cual surge la Universidad, en pleno siglo XVI, en la calle de Manuel Tolsá, frente al edificio de Minería. De manera similar el teatro se representaba así en las calles del México Colonial.

- Morales Campos, Estela. "La lectura y la cultura en el ambiente posrevolucionario de México". En Bibliotecología, sociedad y cultura: el CUIB en la EXPO-UNAM 450 años. (pp. 27-45). México: UNAM. Centro Universitario de Investigaciones Bibliotecológicas, 2003.

Resumen: El trabajo analiza las acciones que se realizaron luego del triunfo de la revolución mexicana para consolidar la cultura, los libros y el papel que desempeñaron los intelectuales de la época para establecer las instituciones que hoy en día juegan un papel tan importante dentro del ámbito cultural del país.

- Ramírez Leyva, Elsa M. "La lectura: un campo de investigación con muchas facetas y muchas incógnitas". En: Coloquio de Investigación Bibliotecológica (20 : México, D. F. : 2002). Memoria (pp. 27-39). México: UNAM. Centro Universitario de Investigaciones Bibliotecológicas, 2003.

Resumen: La autora considera que la lectura es ciertamente un tema que hasta hace poco tiempo era considerado como una problemática exclusiva de la pedagogía y estaba específicamente limitado al proceso de la formación de destrezas de la lectoescritura, transmitida a los individuos para advenir sujetos instruidos. Lamentablemente, y pese a las diversas acciones emprendidas, aun en los países considerados del primer mundo, la capacidad de leer y su práctica cotidiana lejos de mejorar se 
han empobrecido. En el ámbito bibliotecológico se debe tener presente aquello que puede aportarle a la bibliotecología el conocimiento sobre la lectura y, a su vez, lo que ésta puede enriquecer el cuerpo de conocimientos bibliotecológicos.

- Ramírez Leyva, Elsa M. "Information literacy to improve or create reading and information culture" En: International Conference on Information Literacy Experts, 2002.

<http://www.nclis.gov/libinter/infolitconf\&meet/papers.html> Resumen: La autora considera que uno de los desafíos de la Sociedad de la Información es pretender que todos los ciudadanos posean habilidades informativas. Su propósito final es reducir las diferencias enormes en cuanto a las habilidades necesarias para la lectura, acceso y uso de la información, que existen entre las naciones y dentro de la mayoría de sus territorios nacionales. Menciona una investigación de la OCDE sobre las aptitudes de lectura de jóvenes de 15 años, e incluye gráficas. Propone redefinir la función de las bibliotecas, los archivos y la documentación para que tengan un papel central que les permita contribuir en la educación del individuo como un lector bien informado.

- Ramírez Leyva, Elsa M. "Lectura y acceso a la información para la democracia: reto para las bibliotecas latinoamericanas" En: 68 Conferencia General de la IFLA, 2002. < http://www.ifla.org/IV/ifla68/papers/103-084s.pdf>

Resumen: Se analiza la lectura y la información, que la autora considera como un reto para aquellos países latinoamericanos que buscan consolidar sus procesos democráticos. También sostiene que son temas para abrirlos a la reflexión y acción del sector bibliotecario, ya que su participación es particularmente indispensable en el equilibrio social que necesita equidad en la diversidad del mundo contemporáneo.

- Ramírez Leyva, Elsa M. "The impact of the Internet on the reading practices of a university community: the case of UNAM" En: 68 Conferencia General de la IFLA, 2002.

$<$ http://www.ifla.org/IV/ifla69/papers/019e.ramirez.pdf> 
Resumen: Se exponen los resultados de un estudio realizado con estudiantes de la Universidad Nacional Autónoma de México (UNAM) en las Facultades de Filosofía y Letras y la de Ciencias para apuntar con precisión los cambios que el uso de Internet ha generado en sus prácticas de lectura sobre temas educativos de alto nivel con los hábitos de lectura usuales dentro de la cultura del libro impreso. También se reflexiona sobre el papel que desempeñan en esto las bibliotecas. Las preguntas se prepararon de tal manera que los temas no pudieran prever los resultados con respecto a las tendencias de Internet y se basaron en cuatro problemas: la experiencia, los usos, las nuevas prácticas y la percepción.

- Rodríguez Gallardo, Adolfo. "Reading and democracy" En: 68 Conferencia General de la IFLA, 2002.

$$
\text { <http://www.ifla.org/IV/ifla68/papers/153-134e.pdf> }
$$

Resumen: El enfoque sobre el tema de la lectura que el autor expone a través de su trabajo se refiere a los aspectos sociales que están relacionados con la democracia de una sociedad, y presenta algunas paradojas detectadas en su estudio. Si bien algunos Estados dicen fomentar la lectura, al mismo tiempo establecen barreras al acceso a la información mediante el control de los instrumentos de lectura. También menciona que es muy frecuente que se aborde el tema de la lectura desde los aspectos meramente basados en el aprendizaje, como la adquisición de instrumentos que permiten la comprensión de palabras y frases.

\section{Artículos}

- Román Haza, María Trinidad. "Automotivación para leer: descripción de un taller". Investigación Bibliotecológica: Archivonomía, Bibliotecología e Información, 1(3), jul.-dic. 1987, 40-47.

Resumen: Se considera en el artículo que las razones que inciden como mayor fuerza sobre el disgusto por leer son: las experiencia negativas de lectura que se han tenido y la carencia de estímulos para leer. Revela que el objetivo del taller era facilitar en los participantes el desarrollo de una conducta lectora basada 
en: tomar conciencia de cómo nos desmotivan a leer nuestra propias experiencias negativas de lectura; estimular el deseo de leer reconsiderando el valor y trascendencia de esas lecturas en la vida personal; y empezar a provocarse uno mismo, experiencias de lectura gratificante para quedar motivados para leer.

- Román Haza, María Trinidad. "El desarrollo de una conducta lectora a través del aprendizaje significativo". Investigación Bibliotecológica: Archivonomía, Bibliotecología e Información, 3(7), jul.-dic., 1989, 27-30.

Resumen: Se aborda el problema de desarrollar el gusto por leer desde el punto de vista de la psicología humanista, específicamente de la corriente educativa llamada educación centrada en la persona, y se concluye analizando el desarrollo de la conducta lectora con base en la corriente del aprendizaje significativo, que parece un camino prometedor que repercutirá en la formación de lectores.

- Román Haza, María Trinidad. "El enfoque educativo centrado en la persona y el gusto por leer". Educación y Bibliotecas, 7(62), nov., 1995.

Resumen: La autora se propone aplicar la llamada corriente educativa centrada en la persona, basada en la psicología humanista del norteamericano Carl Rogers, para facilitar el desarrollo del gusto por leer. Román cita a Rogers: lo que realmente ayuda y propicia cambios en una persona no es tanto la técnica empleada por el terapeuta sino la capacidad de éste para establecer un tipo de relación basada en ciertas actitudes que facilitan el crecimiento de las personas. Se estima que a la mayoría de los estudiantes no les gusta leer y que imponer la lectura por obligación no favorece en los jóvenes una conducta lectora madura. El problema es la motivación, y ésta debería ser intrínseca. Es necesario que el deseo de leer surja de la persona como una consecuencia de sus experiencias con la lectura.

- Román Haza, María Trinidad. "Encuentro Latinoamericano sobre la biblioteca, la lectura y el niño callejero". Investigación Bibliotecológica: Archivonomía, Bibliotecología e Información, 10(20), jul.-dic., 1996, 41-45. 
Resumen: Describe el encuentro realizado en junio de 1996 que se proponía buscar formas que favorecieran la vinculación de la biblioteca y el libro con lo niños callejeros y sus familias.

- Román Haza, María Trinidad. "Un taller de lectura en las Islas Marías”. Investigación Bibliotecológica: Archivonomía, Bibliotecología e Información, 7(15), jul.-dic., 1997, 46-48.

Resumen: Se describe el taller de sensibilización a la lectura ofrecido dentro del marco del Desarrollo Humano a los Colonos de las Islas Marías (reclusorio) y un seminario sobre autoestima y lectura dirigido a maestros de la escuela primaria. Se incluye el diseño del taller y su realización. Se consideró que los resultados de los talleres fueron positivos en cuanto a participación, atención e interés del grupo y disciplina. Los colonos manifestaron que les gustaría tener más talleres de este tipo. Cabe aclarar que el taller no los dispensó de asistir a sus trabajos y que la participación fue voluntaria en su tiempo libre y no se pasaba lista de asistencia.

- Ramírez Leyva, Elsa M. "La bibliotecología y la sociedad de la información: algunos aspectos a considerar en torno a las prácticas lectoras". Investigación Bibliotecológica: Archivonomía, Bibliotecología e Información, 13(26), ene.-jun., 1999, 135154.

Resumen: Algunas de las características de la llamada sociedad de la información que toman a la tecnología como su base material, a la información como su recurso, y a la educación como el medio para lograr el desarrollo y el bienestar social, se relacionan con el ámbito bibliotecológico, sobre todo en lo referente a prácticas de lectura e información en las que se plantean transformaciones y el surgimiento de nuevas modalidades de comportamiento a partir de documentos y servicios digitales que empiezan a crearse con cánones diferentes a los establecidos por el medio impreso. A partir de esto surgen también significados y símbolos que han empezado a introducirse en el entramando social de manera desigual, dadas las diferentes capacidades de lectura y de recursos para acceder a los nuevos medios, lo que determina las posibilidades para renovar los conocimientos de 
los individuos, o bien, las limitan y reducen el aprovechamiento de la creciente oferta informativa a diversas actividades que dependen cada vez más de esa oferta y de la capacidad de los lectores para aprovecharla.

- Román Haza, María Trinidad. "En torno a la conducta lectora". Libros de México, (53), 1999, 11-24.

Resumen: Se investiga el proceso de compresión lectora, además de la vigencia de la lectura cuando ya existen adelantos tecnológicos que apuntan a cambios fundamentales en la conducta lectora.

- Alfaro López, Héctor Guillermo “Tiempo líquido: la crisis del libro y la lectura”. Investigación Bibliotecológica: Archivonomía, Bibliotecología e Información, 14(28), ene.-jun., 2000, 53-70.

Resumen: A través de la crítica a la obra de Marshall McLuhan, se explica cómo el siglo XX representa un punto de inflexión en la historia de Occidente por ser una centuria en la que se privilegia la forma sobre el contenido, como quedó codificado en el eslogan de Mcluhan: el medio es el mensaje; lo cual se hizo evidente con el desarrollo de los medios electrónicos de información. Esta situación repercutió en la crisis de la producción del libro y la práctica de la lectura, sujeta ahora a una nueva temporalidad que denomino tiempo líquido. Crisis entendida no como punto final, sino etimológicamente como "punto decisivo" a partir del cual se perfila una nueva trayectoria del libro y de la lectura.

- Ramírez Leyva, Elsa M. "La lectura en la sociedad contemporánea". Investigación Bibliotecológica: Archivonomía, Bibliotecología e Información, 15(30), ene.-jun., 2001, 114-131.

Resumen: La lectura en la sociedad contemporánea se ha tornado más compleja por estar inmersa en una cultura mediática, pero también hay que añadir que la industria editorial ha multiplicado y diversificado sus productos editoriales para el consumo. A esto ahora se suman también los medios digitales con una oferta informativa y de actividades a través de un solo aparato, la computadora, y un medio la Internet. Todo ello forma parte de la naciente sociedad de la información que tiende a depender de la tecnología 
de la información, así como de las capacidades y habilidades de sus ciudadanos para generar conocimiento y desarrollos a partir de su propia transformación e información, tecnología y cultura. Es la anterior la otra opción para la lectura en un mundo que tiende a hacer de ella una actividad utilitaria y efímera y reducida al mero entretenimiento trivial.

- Martínez Arellano, Filiberto Felipe "Lectura, libros y bibliotecas" Biblioteca Universitaria:. Nueva Epoca. 4(2), jul.-dic., 2001, 96-100.

Resumen: Aborda el problema de la falta de hábito de la lectura en nuestro país y analiza sus posibles causas, ya que considera que el hábito de la lectura constituye uno de los principales factores para el mejoramiento de diversos aspectos de la vida de los individuos. Sin embargo sólo un reducido número de habitantes de nuestro país posee dicho hábito. Ciertamente las bibliotecas han llevado a cabo una serie de actividades para promover y fomentar el hábito de la lectura, sin embargo las repercusiones de tales actividades no han sido sustanciales.

- Ramírez Leyva, Elsa M. "La lectura: un problema para la sociedad de la información”. Investigación Bibliotecológica: Archivonomía, Bibliotecología e Información, 15(31), jul.-dic., 2001, 195-211.

Resumen: Este artículo abre la reflexión sobre el problema que representa la lectura para la sociedad de la información, la cual deberá distinguirse por contar con ciudadanos capaces de acceder, usar y convertir la información en un bien que conduzca hacia el beneficio individual y colectivo. Sin embargo, el estudio de la OECD, dado a conocer recientemente sobre la capacidad para comprender textos, evaluar informaciones, construir hipótesis y aprovechar conocimientos, reveló serios problemas en la capacidad lectora en jóvenes que concluyeron la educación media en los 36 países encuestados. Por otra parte, el desempeño de las instituciones educativas (en particular la educación superior) relacionado con la capacitación de los alumnos para desarrollar habilidades que les permitan acceder, usar y transformar la información en conocimiento, también ha mostrado 
insuficiencias. Al respecto, la American Library Association definió seis habilidades básicas que supuestamente todo estudiante deber adquirir para dominar las habilidades de lectura. El estudio de la OECD obligará a revisar los factores que afectan y deterioran la capacidad lectora y, de paso, el gusto por ella.

- Alfaro López, Héctor Guillermo "La Biblioteca de Alejandría: el surco de la lectura en el mundo antiguo". Investigación Bibliotecológica: Archivonomía, Bibliotecología e Información, 16(33), jul.-dic., 2002, 48-73.

Resumen: La Biblioteca de Alejandría tiene una significación fundamental en la historia porque marcó el punto fronterizo entre un concepto de biblioteca anterior y el que determinará el desenvolvimiento posterior de las bibliotecas. A partir de ella se dio la división entre la práctica de la lectura en la Grecia clásica y la del Helenismo que será característica de la posterior civilización occidental. La biblioteca tenía una unidad interactuante con el Museo, primer centro de investigación; en aquélla se hacía acopio del saber universal mientras que en éste se producía el conocimiento. Entre una y otra se profundizó y reorientó el surco de la lectura en el mundo antiguo.

\section{Curso y talleres impartidos}

Por otra parte, dentro del programa de educación continua del CUIB se han organizado e impartido una serie de cursos y talleres dentro de las instalaciones del Centro y en otras instituciones. Entre los cursos y talleres que se han organizado e impartido se pueden mencionar:

- Curso "Automotivación para leer" (1986) Impartido en el CUIB por María Trinidad Román Haza.

- Curso "Automotivación para leer" (1987) Impartido en el Instituto Counceling y Crecimiento por María Trinidad Román Haza. 
- Curso "La motivación para leer" (1990)

Impartido en la Universidad de Chiapas por

María Trinidad Román Haza.

- "Taller multimodal de lectura" (1991)

Impartido en planteles de la Escuela Nacional Preparatoria por María Trinidad Román Haza.

- "Sensibilización a la lectura dentro del marco del desarrollo humano" (1992)

Impartido en la Universidad Autónoma de San Luis Potosí por María Trinidad Román Haza.

- "Auto-estima y lectura" (1992)

Impartido en las Islas Marías por

María Trinidad Román Haza.

- "La lectura y la auto-estima en el niño" (1992)

Impartido en las Islas Marías por

María Trinidad Román Haza.

- "Lineamientos para desarrollar el gusto por leer" $(1993,1994)$

Impartido en el CUIB por

María Trinidad Román Haza.

- Taller evale la pena leer? (1995)

Impartido en la Escuela Nacional Preparatoria 2 y El Colegio Victoria por

María Trinidad Román Haza.

- Taller de estimulación de la lectura (1995)

Impartido en el Instituto Asunción por

María Trinidad Román Haza.

- Curso "Formación de lectores: aspectos a considerar en el diseño de programas" (1996)

Impartido en el CUIB por

María Trinidad Román Haza.

- Curso "El desarrollo por el gusto de lectura" (1996)

Impartido en la Universidad Autónoma de San Luis Potosí por María Trinidad Román Haza.

- Curso "Condiciones que facilitan el desarrollo del gusto por leer (taller para maestros" (1996)

Impartido en el Centro Universitario Anglo Mexicano, Plantel 
las Águilas por

María Trinidad Román Haza.

- Curso "Problemas del fomento a la lectura en México" (1996) Impartido en el Centro Universitario Anglo Mexicano, Plantel Sagredo por

María Trinidad Román Haza.

Reuniones y eventos académicos

Asimismo los avances y resultados de los proyectos de investigación en torno a la lectura han sido presentados en distintas reuniones académicas, algunas de las cuales fueron organizadas por los investigadores del CUIB. La participación del cuerpo de investigación del CUIB en reuniones y eventos académicos ha sido la siguiente:

- Mesa Redonda Bibliotecas Publicas y Hábito de la lectura (1985).

Organizadoras: Elsa Ramírez Leyva y Ma. Trinidad Román.

- Panel "Formación de lectores" (1987)

Organizadora: María Trinidad Román Haza.

- Ponencia "Diseño y desarrollo de un taller, centrado en la persona para estimular el gusto por leer" (1992)

En VI Jornadas Bibliotecarias Nacionales

Universidad de Chile

Ponente: María Trinidad Román Haza.

- Ponencia "Reflexiones sobre la participación de la escuela, el hogar y la biblioteca en el desarrollo de la lectura" (1992)

En Conferencia Regional de Promoción de la Lectura

Colegio de Bibliotecarios de Chile, A. C.

Ponente: Estela Morales Campos.

- "Ponencia introductoria de debate de la fotonovela y la historieta" (1993)

En Mesa Redonda Psicología y Lectura

Ponente: María Trinidad Román Haza. 
- Mesa redonda "Sociología y lectura" (1995)

En XVI Feria Internacional del Libro en el Palacio de Minería Moderadora: María Trinidad Román Haza.

Comentarista: Elsa M. Ramírez Leyva.

- "Seminario sobre la lectura y escritura significativas" (1997) Organizadora: María Trinidad Román Haza.

- "Seminario sobre la lectura y escritura significativas para grupos con discapacidad auditiva y visual" (2000)

Organizadora: María Trinidad Román Haza.

- Seminario "Introducción a la historia de la lectura: obras de Roger Chartier" (2000)

Organizador: Héctor Guillermo Alfaro López.

Participación en medios de difusión

Los investigadores del CUIB también han impartido diversas conferencias sobre aspectos relativos a la lectura, así como opinado sobre su problemática en la prensa y otros medios de comunicación.

- "El hábito de la lectura"

Gaceta Universitaria

Abril 1987

María Trinidad Román Haza.

> "El mexicano y la lectura"

Televisión Universitaria, R.T.C. y Televisa

Septiembre 1988

Estela Morales Campos

Ma. Trinidad Román.

- Conferencias de motivación para la lectura

Escuela Nacional Preparatoria, Planteles 1, 2, 56 y 7

Colegio de Ciencias y Humanidades, Planteles Sur y Vallejo 1991

María Trinidad Román Haza.

- "Las bibliotecas y la lectura"

Radio Variedades, Durango

Junio 1991

Estela Morales Campos. 
- "La lectura, notas teóricas"

Documento para programa de TV, 1993

María Trinidad Román Haza.

- "Lectura, consejos prácticos para los padres de familia".

Programa de TV,

1993

María Trinidad Román Haza.

- La lectura y los niños de la calle

Entrevista en Radio RED,

1996

Elsa Ramírez Leyva

María Trinidad Román Haza.

- La lectura en México

Entrevista Radio UNAM,

1996

María Trinidad Román Haza.

- Intentarán que lean los niños callejeros

Diario Reforma,

1996

María Trinidad Román Haza.

- Encuentro Latinoamericano sobre la Biblioteca, la Lectura y los

Niños de la Calle

Entrevista en Canal 22 de México,

1996

Elsa Ramírez Leyva

María Trinidad Román Haza.

- Conferencia "El lector del mundo cibernético"

Universidad Autónoma del Estado de México

1997

Elsa Ramírez Leyva.

- Entrevista "Fomento a la lectura"

NOTIMEX

1997

María Trinidad Román Haza. 
- Entrevista "La lectura en la sociedad mexicana"

TV Veracruzana

1997

Elsa M. Ramírez Leyva.

\section{CONSIDERACIONES FINALES}

En lo anteriormente expuesto puede observarse que la contribución del CUIB a la investigación del fenómeno de la lectura ha sido notable, como lo demuestran los numerosos proyectos de investigación que han sido emprendidos y los productos derivados de ellos. Gran parte de los resultados de esos proyectos de investigación han sido plasmados en los libros y artículos publicados sobre esta temática. También los resultados y avances de los distintos proyectos en torno a la lectura han sido difundidos en numerosos congresos y reuniones académicas. Por otro lado, se ha contribuido a la formación y actualización de bibliotecólogos y otros profesionistas que trabajan en el área de la lectura a través de diversos cursos y talleres de educación continua y actualización impartidos en el CUIB y en distintas instituciones nacionales y extranjeras. De esta forma el CUIB ha contribuido al estudio de los problemas de investigación relacionados con la lectura.

\section{REFERENCIAS}

Cmetmedia.com (2003). Lectura, como se fomenta este hábito en Chile: algunas iniciativas gubernamentales persiguen reencantar a los adultos e incentivar a niños para que lean más. En http:/www.cmetmedia.com/temas/tema6/reportaje75/ (Consultado 28 de septiembre de 2003)

El hábito de leer (2003). En http://www.sysop.com.mx/lecturasparacompartir/superacion/elhabitodeleer.html (Consultado 28 de septiembre de 2003) 
Literatura infantil (2003). Bloque I. La literatura infantil en la escuela. En http://www.geocities.com/crachilecl/litinf.htm (Consultado 28 de septiembre de 2003)

UNAM. Centro Universitario de Investigaciones Bibliotecológicas (1993). Informe de actividades 1985-1992. México: UNAM. Centro Universitario de Investigaciones Bibliotecológicas.

UNAM. Centro Universitario de Investigaciones Bibliotecológicas (1997). Informe de actividades 1993-1997. México: UNAM. Centro Universitario de Investigaciones Bibliotecológicas.

UNAM. Centro Universitario de Investigaciones Bibliotecológicas (2001). Informe de actividades 1993-2001. México: UNAM. Centro Universitario de Investigaciones Bibliotecológicas.

Vidriales, Miriam. (2001). Razones para no leer. Escala, noviembre 2001, p. 92-94. 


\title{
El extraño objeto que nos reúne
}

\author{
Michèle Petit
}

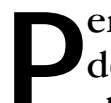

rmítanme agradecer profundamente al Centro Universitario e Investigaciones Bibliotecológicas de la UNAM, y en particular al doctor Filiberto Martínez Arellano, a la Maestra Elsa Ramírez y al doctor Juan José Calva por hacerme el gran honor y el placer de invitarme a pronunciar esta conferencia. Les agradezco aún más puesto que me une con América Latina -y sus habitantes- una relación de complicidad y de cariño, ya que hace siglos pasé aquí una parte de mi adolescencia, y es siempre con alegría que regreso a esta región. Además México es el país que, gracias a Daniel Goldin y al Fondo de Cultura Económica, me ha brindado la oportunidad de dar a conocer mi trabajo en todo este continente y por tanto siento una gratitud particular por él.

Cuando le pregunté a Elsa, hace algunas semanas, qué tema deseaba que abordara, me sugirió que hablara de los mediadores; lo que, les confieso, me hizo sentirme un tanto incómoda. ¿Tenía algo nuevo qué decir sobre este tema, algo diferente de lo que había podido escribir

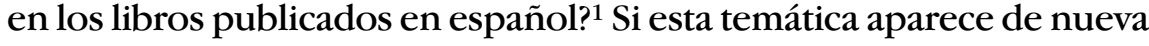
cuenta, si nos la proponen regularmente, debe representar la expresión de una inquietud en cuanto al papel de estos mediadores de la

1 - Nuevos acercamientos a los jóvenes y la lectura, México, Fondo de Cultura Económica, Col. «Espacios para la lectura», 1999 (traducido del francés por Rafael Segovia y Diana Luz Sánchez)

-Lecturas: del espacio íntimo al espacio público, México, Fondo de Cultura Económica, Col. «Espacios para la lectura», 2001 (traducido del francés por Miguel y Malou Paleo, y Diana Luz Sánchez). 
lectura en éste nuestro mundo cambiante. En mi país, donde me encuentro frecuentemente con bibliotecarios y profesores, me impresiona la incertidumbre a la que se confrontan con respecto al porvenir de su profesión. Por ejemplo, en el transcurso de los últimos meses me encontré varias veces con bibliotecarios preocupados por constatar, durante dos años seguidos, una ligera disminución en la asistencia del público. Se preguntaban si con la consulta en línea y con la invasión de las bibliotecas por pantallas en detrimento de los libros, no nos dirigíamos hacia una metamorfosis de esos lugares y una desaparición de los mediadores, o al menos a su conversión en técnicos de la información.

Sin embargo, si estamos atentos a la experiencia de los lectores, de los usuarios -particularmente en los ambientes populares-, la tarea de los mediadores no se limita en absoluto a esta función, sea cual sea su importancia. Es lo que trataré de mostrar hoy, y con este fin me dedicaré a evocar los procesos de la transmisión y la apropiación de la lectura en nuestras sociedades, e intentaré acercarme a lo que uno busca alcanzar a través de los libros, en la infancia y después. Para identificar lo que está en juego en la relación entre un mediador, un niño o un adolescente, y un libro, abordaré luego formas de leer discretas o secretas, cuya importancia es a menudo desconocida o subestimada, y dejaré deliberadamente de lado otros usos de la lectura; como todo aquello que se relaciona con el acceso a la información y los usos paraescolares o autodidácticos, porque todo esto es bastante bien conocido. Intentaré esclarecer el posible porvenir de la lectura, lo que está en juego con su democratización, y el margen de maniobra de los mediadores y las aporías de su posición.

\section{EL PRIMER MEDIADOR: LA MADRE... O LA ABUELA}

¿Cómo se vuelve uno lector? Diferentes encuestas lo probaron, en Francia como en otros países industrializados, la lectura es un arte que se transmite más que enseñarse. La mayor parte de los lectores que leen regularmente desde la infancia tienen otra relación con la 
lectura que aquellos que leen poco o nada: ${ }^{2}$ así, en mi país, las dos terceras partes de los grandes lectores, ya lo eran entre los ocho y doce años. ${ }^{3}$ El medio familiar tiene en este caso una influencia determinante, aunque parezca haberse atenuado un poco entre las nuevas generaciones. Antes que el profesor, antes que el bibliotecario, el primer mediador es la madre, y algunas veces también el padre, cuando él mismo es un gran lector o valora mucho la lectura.

Pero más precisamente ¿cómo le viene el gusto por la lectura a un chico o a una chica, en su familia? Ustedes lo saben, ninguna receta garantiza que un niño leerá, pero las encuestas insisten en la importancia de la presencia de los libros en la casa, en particular en la habitación del niño. Sin embargo esta presencia sólo parece tener una influencia positiva en el gusto por la lectura si el libro vive con la familia y en particular si se vuelve objeto de conversaciones. Se resalta igualmente el papel de las lecturas en voz alta: en Francia, el peso de los grandes lectores es dos veces más importante entre los que se beneficiaron de una historia contada diariamente por su madre que entre los que no escucharon ninguna. ${ }^{4}$ La capacidad para establecer con los libros un vínculo afectivo, emotivo y, no solamente cognitivo, parece decisiva. Así como también el hecho de ver a sus padres leer: los investigadores hablan de «ejemplo parental», de «mimetismo» o de transmisión por «imitación». Pero tales expresiones no elucidan gran cosa. Los niños ven a su madre todos los días dedicarse a mil otras actividades sin tener por ello ganas de imitarla. En ciertos campos, es incluso necesario insistir mucho para que se decidan a imitarla.

Y es ahí donde la atención enfocada a la experiencia singular de aquellos y aquellas que tomaron gusto por los libros puede quizás

2 Véase por ejemplo Erich Schön, "La fabrication du lecteur", in Martine Chaudron et François de Singly, Identité, lecture, écriture, París, BPI/Centre Georges Pompidou, 1993 ; François de Singly, Les Jeunes et la lecture, ministère de l'Éducation nationale et de la Culture, Dossiers Éducations et formations, 24, janvier 1993; Hélène Michaudon, "La lecture, une affaire de familles", INSEE, n777, mai 2001.

3 Hélène Michaudon, op. cit.

4 François de Singly, op. cit., p. 102. 
enseñarnos un poco más. Quisiera detenerme en esta pregunta: ¿Qué pasa cuando un chico, una chica, ve a su madre o a su padre leyendo ? Poca gente ha guardado un recuerdo preciso de ello; en las entrevistas, la mayoría no va más allá de frases como ésta: «Nunca me obligaron, pero de tanto verlos...» Erich Schön, que estudió un corpus de autobiografías de lectores redactadas por estudiantes de letras, escribe : «Nos dicen que cuando miraban a sus padres u otros personajes importantes para ellos absortos en un libro, los envidiaban». 5 ¿Pero qué envidiaban exactamente? La experiencia de algunos escritores nos permite acercarnos a una respuesta. Por eso me esforcé en reunir algunos de sus recuerdos de iniciaciones a la lectura, mayoritariamente las fechadas en la segunda mitad del siglo XX.

En un texto titulado El caballero de los brezos, ${ }^{6}$ el escritor español Gustavo Martín Garzo relata así un recuerdo que es como la escena inaugural de su vida de lector. A los seis años, de regreso de la escuela, entra en la casa, nota la oscuridad, la frescura, el silencio «profundo, misterioso, como animado por una respiración imperceptible», lo cual contrasta con la calle. Busca a su madre, la encuentra en la cocina, sola, leyendo «en medio de un círculo encantado». Se detiene a mirarla, se acerca hasta tocar la mesa para hacerla regresar a él. Ella le dice que lee una novela de amores desgraciados, El caballero de los brezos, pero en su rostro hay una expresión de felicidad como si le ocultara algo, algo relativo a los secretos más hondos de su vida. Y lee un fragmento en voz alta, que describe el cuerpo y el rostro de una joven. Varias veces, el niño va a robar $E l$ caballero de los brezos $\mathrm{u}$ otras novelas, para leerlas en un pequeño cuarto bajo las escaleras, con una linterna, sin lograr adentrarse en el misterio, sin sorprender en sí mismo el embeleso, la emoción, que ha visto en el rostro de su madre: «Busco esa emoción, el sentimiento de estar traspasando una frontera, pero no lo consigo.»

5 Erich Schön, op. cit., p. 24.

6 El caballero de los brezos, en El hilo azul, Madrid, Aguilar, 2001, p. 21-31. Agradezco a Jordi Artigal por hacerme descubrir este hermoso libro. 
Es solamente una decena de años más tarde cuando, leyendo por azar a El capitán Tormenta, surge a su alrededor ese "círculo de tiza de la adivinación y el pensamiento» en que tantas veces vio detenida a su madre. Y es que el libro contiene una sorpresa: el capitán valeroso es en realidad una muchacha que, en la intimidad de su carpa, se despoja de la pesada armadura que oculta «la realidad proscrita de su sexo».

En el corazón de cada historia, sugiere el escritor, hay quizás la revelación de un cuerpo imprevisible, libre, sin ataduras, arrebatado por el deseo; y en el corazón de toda lectura, la búsqueda de un secreto que se refiere al deseo, al amor y, también, de vez en cuando, al primer ser amado. En efecto, las lecturas de Martín Garzo no serían, según él, más que una tentativa de elucidar el misterio de la escena inaugural: «Esos libros son entonces el que ella estaba leyendo. Todos los libros El caballero de los brezos. Lo he tomado en secreto (de hecho durante un tiempo nada me gustó más que robar los libros que iba a leer) y vuelvo a estar escondido en el cuarto que había bajo las escaleras. Eso es leer para mí, estar escondido. Todos los libros son ese único libro, y yo me inclino sobre sus páginas tratando de adivinar los pensamientos de mi madre joven y hermosa».

Lo que dice Martín Garzo, lo que encontré en otros recuerdos de lectura transcritos en obras literarias o relatados por lectores «ordinarios», es que el gusto por la lectura nace frecuentemente del deseo de robar el objeto que embelesaba al otro, para reunirse con él, conocer su secreto, adueñarse del poder, del encanto que se le atribuía, cuando él -o ella, ya que es a menudo de la madre de quien se trata- estaba ahí, inaccesible, lejano(a), perdido(a) en sus pensamientos. Es que esta apetencia tiene que ver también con la búsqueda del otro en uno mismo, desconocido, de repente revelado, reclamando su lugar en el mundo.

Desde luego no todo mundo tiene la fortuna de encontrarse a su madre leyendo en la cocina, de poder hurtar libros en su casa o de manipularlos desde una edad temprana. Cuando alguien crece en un ambiente pobre, todo puede sumarse para disuadirlo de leer: pocos libros (o ninguno) en la casa o en el barrio, o la idea de que eso no le corresponde, y la preferencia por actividades colectivas antes que 
por esos placeres «egoístas», o las dudas con respecto a la «utilidad» de la lectura, etcétera. ${ }^{7}$

No obstante, incluso en entornos muy apremiantes, existen familias donde el gusto ávido por los libros se transmite de una generación a otra -por la madre más a menudo, y por el padre algunas veces, especialmente cuando éste es un autodidacta, o por los dos padres. Varios trabajos lo han demostrado: las condiciones favorables para la lectura parecen más ligadas a las representaciones y comportamientos socio-culturales de los padres que a su origen social. Puede resultar menos paralizante tener padres que, aunque analfabetos, valoran los conocimientos y el libro, y manifiestan regularmente con palabras o gestos su deseo de que sus hijos se apropien de esa cultura escrita de la que ellos carecieron, que padres que tuvieron una escolaridad caótica y que siguen teniendo una relación muy ambivalente con la escuela y los libros, lo cual van a transmitirle a sus hijos, de forma consciente o no. ${ }^{8}$ Dicho de otro modo, en mi país al menos, más que la presencia o la ausencia física de los libros en la casa, más que el nivel escolar alcanzado por los padres, cuenta el interés profundo que éstos manifiestan hacia los libros, aunque no hayan tenido acceso a ellos, aunque sean analfabetas. Es la relación de deseo o de rechazo por estos objetos, lo que facilita la apertura de un camino hacia la lectura o lo que dificulta su acceso. Un tanto de la misma forma que la atención brindada por su madre a los libros intrigó al escritor antillano Patrick Chamoiseau en su infancia: «Me habían atemorizado con cuentos, arrullado con canciones infantiles, consolado con cantos secretos; pero en esos tiempos los libros no eran cosa de niños. Así pues, me encontré solo con esos libros dormidos, inútiles, pero que recibían los cuidados de man Ninotte (su madre). Eso

7 Cf. Michèle Petit, obras citadas.

8 Véanse Bernard Lahire, Tableaux de familles, París, Gallimard/Le Seuil, 1995 ; Zaïhia Zeroulou, "Mobilisation familiale et réussite scolaire", Revue européenne des migrations internationales, 1 (2), p. 107-117 ; Bernard Charlot, Elisabeth Bautier et Jean-Yves Rochex, École et savoir dans les banlieues... et ailleurs, París, Armand Colin, 1992. 
fue lo que llamó mi atención: Man Ninotte se interesaba en ellos a pesar de que no tenían utilidad alguna. Yo observaba cómo utilizaba los alambres, los clavos, las cajas, las botellas o los garrafones recuperados, pero nunca la vi hacer uso de esos libros que tanto cuidaba. Eso era lo que intentaba comprender al manipularlos sin cesar. Me maravillaba de su complejidad perfecta cuyas razones profundas desconocía. Les atribuía virtudes latentes, sospechaba que eran poderosos.»9

\section{ANTES DE LOS LIBROS, LOS CANTOS SECRETOS}

Ahí de nuevo porque representan un pasaje hacia un ámbito misterioso, hacia los arcanos del poder, es que los libros son deseables. Pero es también porque antes de esto, «cantos secretos» interpretados por voces cariñosas, canciones infantiles mezcladas con gestos de ternura, envolvieron al niño y lo encantaron con un uso tan esencial como inútil, el uso de la lengua. Antes del encuentro con el libro, existe la voz, la voz de la madre que está ahí desde antes del nacimiento, que marca luego el despertar psíquico del bebé, el enunciado de las primeras sílabas. Esa voz cuyas modulaciones cambian según que la madre hable de la realidad cotidiana o que se abandone a la fantasía, y a las cuales muy pronto el niño es sensible.

El gusto por la lectura no solamente depende, en gran medida, del interés que los padres mismos expresaron por los libros, sino también y antes que eso, de esos intercambios precoces que la madre (o la persona que la representa) tuvo con su hijo, en donde el registro afectivo, la solicitación sensible y tónica del cuerpo, y el juego del lenguaje traído por las escansiones y las entonaciones de la voz, están estrechamente entremezclados. Todos los grandes especialistas de la primera infancia subrayan la importancia que tiene, para el despertar sensible, intelectual y estético de los niños, la capacidad de las madres para estar al compás con lo que ellos sienten y para regresarles ecos gestuales

9 Ecrire en pays dominé, París, Gallimard, 1997, p. 31. Citado en Nuevos acercamientos..., op. cit. p. 147. 
y del lenguaje, pero también para filtrar, gracias a su «capacidad de ensoñación», los miedos de los niños, y aun para dedicarse en su compañía a este uso ficticio, gratuito, de la lengua -en donde se alternan canciones, confidencias, rimas, etcétera. ${ }^{10}$

De la calidad de la presencia materna depende igualmente la constitución de lo que se llama, desde Winnicott, el área transicional, que es esencial tanto para la emancipación progresiva del pequeño ser humano como para el futuro de sus «experiencias culturales». ${ }^{11}$ Efectivamente, es en un área de juego que se inaugura entre el niño y su madre, donde el niño comienza a construirse como sujeto -si se siente en confianza. En esa zona tranquila, sin conflictos, se apropia de algo que su madre le propone: un objeto, una rima, una historia. El objeto, el relato, la rima, simbolizan la unión de esos seres que en adelante estarán diferenciados, restablecen una especie de continuidad, permitiendo que se supere la angustia de separación y, luego, que se soporte la ausencia.

Fortalecido con la historia o la cancioncita incorporada que lo protege, el niño puede alejarse un poco y se lanza, algo lo empuja, desde su cuerpo; la subjetividad es también una modalidad del cuerpo, si seguimos a Winnicott. Comienza a trazar su propio camino, a percibirse como separado, diferente, capaz de crear un pensamiento independiente. Puede elaborar su capacidad de estar solo en presencia del adulto, construir su espacio del secreto: algo se les va de las manos a los adultos con estos primeros trazos de una interioridad, de una subjetividad; de una capacidad para simbolizar y entrar en relación con los otros, más allá de la unión primera, más allá de los brazos maternos. Espacio psíquico más que material, el área transicional es así paradojal, entre apego y desapego, unión y separación.

10 Véanse las obras de Donald Winnicott, Wilfred R. Bion, Donald Meltzer, Daniel Stern, René Diatkine. Véase también Marie Bonnafé, Les Livres, c'est bon pour les bébés, París, Calmann-Lévy, 2001.

11 Donald W. Winnicott, Jeu et réalité. L'espace potentiel, París, Gallimard, 1975. 
Si este espacio se pudo establecer «si tenemos un lugar donde poner lo que encontramos» ${ }^{12}$, como dice Winnicott, cada uno de nosotros podrá sacar algo de la cultura que hereda, y contribuir a esa cultura. Si tal espacio no se pudo establecer bien porque la madre estaba enlutada o demasiado deprimida, porque no «cantaba», y porque ningún tercero cariñoso desempeñó este papel con el niño, es muy probable -pero no del todo seguro, ya que el porvenir humano nunca está escrito- que tendrá más dificultades para apropiarse, más tarde, de bienes culturales, para hacerlos verdaderamente suyos. ${ }^{13}$

Es que durante toda la vida las experiencias culturales no son sino una extensión de estas primeras experiencias de juego, de vida creadora, de emancipación. Son vías privilegiadas para hacernos recuperar tanto ese espacio apacible como la experiencia del niño, quien a partir de ese espacio tranquilo, protector, estético, entre su madre y él, se rehace y se vuelve autónomo. Cantar, leer, apropiarse de los libros, es encontrar el eco lejano de la voz de la madre, el apoyo de su presencia carnal; es así como Martín Garzo se inclina sobre las páginas de los libros para encontrar a su madre joven y hermosa. Es también así como se desprende de ella a través de la simbolización.

Pero si bien el libro es el eco lejano de la voz de la madre, está hecho de signos, de lenguaje, de ese registro simbólico que los psicoanalistas sitúan más bien del lado del padre; una instancia tercera

12 Op. cit., p. 137.

13 Por supuesto el contexto social viene a sumarse a la historia inconsciente; por ejemplo, en nuestra sociedad y en nuestra época, la práctica de la lectura supone una capacidad de estar solo que no únicamente depende de las relaciones precoces con la madre, sino también de la manera en que se percibe el hecho de mantenerse alejado del grupo: este comportamiento, valorado en ciertos medios, será considerado como una grosería en otros. No hace falta mencionar que las mismas condiciones de vida -el hábitat en primer lugar- no favorecen el establecimiento de dichas costumbres...

Determinaciones económicas, sociales y psíquicas se combinan así en un juego complejo para dificultar la lectura o bien para facilitarla. No obstante, siempre será posible alguna reorganización, y es ahí donde el papel de los mediadores resulta ser esencial. 
separadora. Y acceder a la lectura es a veces descrito como incorporar algo que es propio de la madre,${ }^{14}$ pero de lo que no está probablemente ausente el padre, o el ser amado por la madre, con quien ella sueña. Es decir, lo que puede ser apropiado, incorporado, tiene en la vida psíquica un estatus complejo, compuesto.

En su autobiografía titulada Les mots (Las palabras), Sartre dejó un relato muy detallado de su iniciación a la lectura, del que no retomaré aquí más que un fragmento que corresponde al momento en que, después de varias tentativas para apropiarse de los libros imitando los gestos de su abuelo, el narrador termina por poner éstos en las rodillas de su madre: «... se inclinó, bajó la mirada, se durmió. De ese rostro de estatua salió una voz de piedra. Perdí la cabeza: ¿Quién contaba? ¿Qué? ¿Y a quién? Mi madre se había ausentado: ni una sonrisa, ni una muestra de convivencia, estaba yo en el exilio. Además no reconocía su lenguaje ¿De dónde tomaba esta seguridad? Al cabo de un instante había entendido: era el libro el que hablaba».

Sin embargo conoce la historia, su madre se la contó mil veces, improvisando, y estaban entonces, según sus propias palabras, «solos y clandestinos» como «dos ciervas familiares». Pero aquel día el libro está ahí como un tercero entre el niño y la madre, y es él el que habla, conferiendole a la madre una seguridad, un poder. Y dándole al niño el sentimiento de ser arrancado de sí mismo, que poco a poco se tornerá placentero.

Sartre precisa: «Estuve entonces celoso de mi madre y resolví tomar su papel. Me adueñe de una obra titulada Tribulaciones de un chino en China y lo llevé a un armario; ahí, colgado en una cama plegable, fingí leer y me conté una historia en voz alta.» ${ }^{15}$ Lo sorprendieron y decidieron enseñarle el alfabeto.

14 Melanie Klein escribía, según Strachey, «que, en el inconsciente, leer significa tomar la ciencia del interior del cuerpo de la madre, y que el miedo a despojarla es un factor importante de las inhibiciones de la lectura». Cf. Melanie Klein, "Contribution à la théorie de l'inhibition intellectuelle”, en Essais de psychanalyse, París, Payot, 1968.

15 Jean-Paul Sartre, Les Mots, París, Gallimard, 1964, pp. 34 y 36. 
En ciertos contextos familiares, culturales, otras personas distintas de la madre van a permitir el establecimiento precoz del espacio transicional, o su extensión -en particular una abuela, una tía o una nana a quien le sea confiado el niño. La importancia de la abuela en recuerdos de infancia transcritos por escritores latinoamericanos parece así impactante. Pensemos, por ejemplo, en Graciela Montes que escribe: «Tuve cuentos, muchos libros, canciones, dibujos, trozos de imaginería. Pero no sé si habría tenido la audacia de aprovechar las ocasiones si antes no hubiese tenido esa escena, la de mi abuela contándome el cuento del asno delirante y justiciero», ${ }^{16}$ cuento que comprendía, por supuesto, algunas fórmulas mágicas e incomprensibles.

O pensemos en Reinaldo Arenas: «Desde el punto de vista de la escritura (añadiría; y de la lectura), apenas hubo influencia literaria en mi infancia; pero desde el punto de vista mágico, desde el punto de vista del misterio, que es imprescindible para toda formación, mi infancia fue el momento más literario de toda mi vida. Y eso se lo debo en gran medida a ese personaje mítico que fue mi abuela, quien interrumpía las labores domésticas y tiraba el mazo de leña en el monte para ponerse a conversar con Dios.» ${ }^{17}$

En el momento en que copiaba estos ejemplos, gracias a la fortuna, que hace tan bien las cosas, encontré algunas páginas del antropólogo Daniel Fabre, que evocan trayectorias de apropiación de la lectura a partir de autobiografías de mujeres de estirpe popular y burgués, entre 1780 y 1960; revela ahí, en el caso de Italia, el lugar prominente que ocupa la abuela: «vinculada con el saber oral y garantizando en la casa la presencia física del pasado, es el punto de referencia de otro tiempo, a la vez fabuloso e histórico, que ya no se podrá encontrar verdaderamente más que en los libros.» ${ }^{18}$ De una manera más amplia, Fabre nota la importancia de una transmisión

16 Graciela Montes, La frontera indómita, Mexico, Fondo de cultura económica, Col. «Espacios para la lectura», 1999, pp. 29-30.

17 Reinaldo Arenas, Antes que anochezca, Tusquets, Barcelona, p. 45.

18 Daniel Fabre, Lire au féminin, Clio, Presses Universitaires du Mirail, Toulouse, «Parler, chanter, lire, écrire », 11/2000, pp. 192-193. 
que hacen las mujeres y precisa: «las madres, abuelas y tías figuran entre las iniciadoras, no tanto porque favorecen directamente la lectura sino, más sutilmente, porque hacen deseable la apropiación de ésta». Es exactamente eso.

\section{EL PAPEL DECISIVO DE LAS MUJERES EN LA TRANSMISIÓN DE LA LECTURA EN LA ÉPOCA CONTEMPORÁNEA}

La mayoría de las veces, en las sociedades occidentales contemporáneas, es efectivamente una mujer la que parece poseer las llaves de ese arte percibido por los niños como mágico, secreto. A veces puede ser ejercido por una narradora, otras por una mujer leyendo en el círculo encantado de su soledad soñadora, como vimos antes. Por otra parte, en estas sociedades, el lector es a menudo una lectora, a tal punto que Christine Garbe, que nos hablará tal vez de eso, sugirió tomar a la lectora como paradigma. ${ }^{19}$ Todas las encuestas confirman que las mujeres mantienen una relación más estrecha con lo escrito, y en particular con la lectura de ficción, en todos los ámbitos sociales: en Francia, por ejemplo, las dos terceras partes de lectores que leen al menos un libro al mes son en realidad lectoras; ${ }^{20}$ y son casi tres veces más numerosas cuando se trata de la lectura de novelas. ${ }^{21}$

En ciertos contextos esa proximidad de las mujeres y de los libros vuelve a éstos deseables tanto para las chicas como para los chicos. No es sorprendente: de la misma manera les intriga la ensoñación materna, los secretos de familia, los misterios de la vida y de la muerte, y los de la diferencia sexual o del amor. Tanto unos como otras piensan que las respuestas a esas preguntas se encuentran tal vez en los libros con los cuales su madre, o algunas veces su abuela, mantienen un extraño

19 Christine Garbe, Les femmes et la lecture, in Identité, lecture, écriture, op. cit., p. 187-212.

20 Hélène Michaudon, op. cit.

21 Olivier Donnat, Les Pratiques culturelles de Français, Enquête 1997, París, La Documentation française, 1998, p. 173. 
comercio. En cambio en otros contextos esta afinidad entre las mujeres y la lectura, y el hecho que la interioridad se asocie con las mujeres, llevan actualmente a muchos varones a rechazar los libros en la pubertad o su acercamiento a ellos, como rechazarían estar atados a las faldas de sus madres; así como Sebastien, de trece años, que le dice a la bibliotecaria que le pregunta si le gusta siempre leer tanto «Oh no! Ahora ya soy grande, iya no leo!». Esto conduce también a lectores varones a esconderse para leer, con el fin de evitar las represalias de aquellos que los ven como traidores a su sexo y a su entorno social.

Así, vemos que leer supone probablemente hoy, para un chico, aceptar su parte femenina. Esto se hace sin demasiadas dificultades en ciertos medios, como el medio burgués «culto» donde la identidad masculina acepta integrar una parte de los valores asociados a las mujeres, e incluso sale reforzada con ello, o como en ciertas familias populares en que los padres son autodidactas; en otros, al contrario, se observa actualmente un regreso de muchos chicos a una «oralidad exclusiva o a una escritura violentamente exteriorizada y públicamente transgresora», ${ }^{22}$ en forma de grafitis. En Francia, las diferencias entre los sexos tienden actualmente a ahondarse en el campo de la lectura; y el carácter mixto de la escuela, lejos de reducirlas, ha tenido tal vez por efecto reforzar algunas de ellas, al menos en la fase actual. Por otra parte las mujeres efectúan ahora lo esencial de los actos cotidianos de escritura en el espacio doméstico, y para los hombres de las clases populares, las ocasiones de escribir pueden haberse vuelto extremadamente escasas, $\mathrm{o}$ incluso casi inexistentes. ${ }^{23}$

Pero no se trata de una división tranquilamente asumida. En efecto, si rechazan los libros y en un sentido más amplio lo escrito, algunas veces con rabia, una parte de los chicos piensan, ellos también, que existe en los libros un secreto vital del cual están privados; y es un sufrimiento para ellos, aunque traten de disimularlo, tal como ese

22 Daniel Fabre, op. cit., p. 197.

23 Bernard Lahire, Masculin-féminin : l'écriture domestique, in Daniel Fabre (ed.), Par écrit : ethnologie des écritures quotidiennes, París, Ed. de la Maison des Sciences de l'Homme, 1997, pp. 145-164. 
joven taxista que se acuerda: «En la escuela, les pegábamos a quienes les gustaba leer. Creo que en el fondo era envidia: nos preguntábamos que es lo que podía haber en los libros.»

No cabe sorprenderemos de que una proporción creciente de chicos rechace los libros. Numerosos factores -y en primer lugar la omnipresencia de lo visual en nuestras sociedades, la violencia cruda que destilan ciertos medios de comunicación, el crecimiento de una búsqueda obsesiva de visibilidad en el espacio mediático, mientras que se reducen la posibilidades de una inscripción política en el espacio público-, lo que hacen es fortalecer un cierto funcionamiento psíquico y social caracterizado por la exhibición narcisista: un tiempo instantáneo, inmediato, una actividad pulsional irreprimible, una voluntad de omnipotencia.

Sin embargo entre los jóvenes que mis colegas y yo conocimos durante nuestras entrevistas en los barrios marginados, hace algunos años, algunos habían pasado del gregarismo viril de la calle a la frecuentación de una biblioteca. Y en el fondo parecía que pocas cosas habían sido suficientes, en ciertos momentos, para que se encaminaran hacía un lado y no hacía el otro; que había bastado el encuentro, incluso ocasional, con un adulto referencial que les había transmitido un poco de sentido, brindado la idea de que existía otra cosa, cambiado la representación ligada a los libros, a lo escrito; que había hecho deseable, posible, una apropiación.

\section{UNA DIMENSIÓN DE APROPIACIÓN SALVAJE}

La lectura es una apropiación singular, pues de otro modo los libros son letra muerta. Incluso en familias en donde se les proponen libros a los niños, éstos sienten la necesidad de reapropiárselos; por ejemplo haciendo ostentación de preferencias que irritan el gusto familiar, o leyendo debajo de las sábanas con la lámpara de mano, para preservar la parte clandestina, transgresora de la lectura. O hurtándolos: recordemos a Martín Garzo de niño, robando El caballero de los brezos u otras novelas para leerlas a escondidas, al joven Sartre queriendo tomar algo de su madre y retirándose lejos de las miradas familiares. Estos escritores 
apuntan hacia aspectos esenciales de la llegada a la lectura que se encuentran también en las experiencias de muchos lectores. Identifican esa dimensión de apropiación, de robo, de desviación, cuya importancia no se aprecia lo suficiente, probablemente porque siempre atemorizó, ya que ninguna autoridad puede controlar la forma en que un texto se leerá, entenderá, interpretará. Esta dimensión actúa entonces desde la infancia, desde esos momentos quizás, en los que el niño se adueña, como lo vimos, de una canción infantil o de un fragmento de una historia que su madre le propone, y lo considera como un bien suyo, como algo que él creó, mientras que fue ella quien se lo dio. Dicha dimensión continúa a lo largo de la vida, a pesar de las tentativas de la escuela por introducir a los alumnos en una lectura normada y por inducirlos a renunciar a una lectura que se tome demasiadas libertades con el texto.

En efecto, resulta fácil notar hasta qué punto la piratería y la desviación son intrínsecas a la lectura: nosotros lo sabemos bien, que por rigor profesional nos vemos obligados a retornar varias veces a nuestras fuentes para limitar los riesgos de los alejamientos del sentido, o las torsiones que espontáneamente estamos tentados a infligirles a los textos de los que nos nutrimos: pues se trata de una pulsión oral que actúa, con su componente ávido, violento.

Aunque hayamos aprendido a controlar nuestra lectura, a frenar nuestras pulsiones de arrancar o recortar las páginas, o de plagiar, leer implica siempre una forma de despedazar: los lectores atacan la integridad del texto, «cazan furtivamente» cierta frase, tal pasaje (para hablar como Michel de Certeau, que había tenido buen tino al escoger ese concepto de «caza furtiva», que remite a una práctica que no está desprovista de crueldades); ${ }^{24}$ apartan cierto fragmento, lo llevan en sus pensamientos para entregarse a unas exégesis insólitas. Pero estas apropiaciones salvajes tienen una función vital: les permiten a los lectores convertirse

24 Michel de Certeau, Lire: un braconnage, in L'Invention du quotidien, 1/ Arts de faire, París, 10/18, 1980. 
en los narradores de su propia historia, y entre las líneas leídas, construir un sentido. Y eso, desde la primera infancia.

\section{CONSTRUIRSE: ¿LLO QUE ESTÁ EN JUEGO A TRAVÉS DE LA} LECTURA HOY?

Desde muy jóvenes, los niños interrogan a los libros -si tienen la suerte de tener acceso a ellos-, buscando en ellos lo que está secretamente en contacto con sus propias preguntas, lo que podrá brindarles una versión personal de sus dramas íntimos. Con un sentido del hallazgo que desconcierta, encuentran en los libros materia para elaborar su «novela familiar», ese pequeño cuento que cada uno construye para superar la decepción provocada por los padres reales; para alimentar los expedientes, el pequeño teatro gracias al cual se consuelan de la dura realidad; para darle forma a las fantasías, los deseos, los miedos; para investigar los misterios de la vida, de la muerte, de la diferencia sexual.

Más allá de la infancia, cuando uno cuenta su trayectoria lectora, siempre evoca frases, historias «robadas» de los libros que usó, muchas veces de manera insólita, para edificar su «casa interior». Es ya la construcción de un espacio propio lo que está en juego en la lectura. Así como Sartre con el armario, Martín Garzo con el pequeño cuarto bajo las escaleras, Rabela, una joven de origen argelino, me habla del ropero en donde se escondía de niña, con los libros prestados de la biblioteca, y Fabienne del árbol al que trepaba con sus historietas. Más allí, las metáforas espaciales abundan en los recuerdos de lectura: numerosos chicos y chicas asocian espontáneamente esta práctica con una cabaña en la jungla, una casucha en una isla, un escondite de papel, etcétera.

Es de la construcción de un espacio propio de lo que se trata, de un tiempo para sí, un tiempo de ensoñación, y de un esbozo de relato de la propia historia. Pues de la obra leída -cuento, novela, poesía, teatro, diario, historieta, ensayo, etcétera- regresa a veces un eco de lo que era indecible, aclarando una parte de sí hasta ese momento oscura, a la manera del insight psicoanalítico: -esas tomas de conciencia repentinas 
que se acompañan de una sensación de placer, de energía recuperada. Como para esta joven mujer, Pilar, quien dice: «Es, tal vez, porque el otro lo dice mejor que yo. Hay una especie de fuerza, de vitalidad que emana de mí porque lo que esa persona dice, por equis razones, yo lo siento intensamente». O para Nicole, al acordarse, con el rostro deslumbrante: «los libros generaban en mí deseos aterradores». O para el escritor Georges-Arthur Goldschmidt, quien evoca la lectura de unos extractos de las Confesiones de Rousseau descubiertos en un manual de literatura durante su adolescencia: «Fue como si me golpeara un rayo, como si alguien hubiera adivinado esas líneas a través de mí, como si ellas me reconocieran. De manera que había habido otra persona que, en lo más secreto de su ser, se había sentido de la misma forma y de quien, a través de su propio cuerpo, se podía adivinar cómo había sido él mismo en su interior. Me invadió un entusiasmo, un sentimiento triunfante nunca antes conocido de legitimidad. Otros, antes que yo, iy quiénes! habían sentido las mismas emociones... Ahora, todo a mi alrededor estaba en el orden natural[...]»25

Por haber realizado entrevistas en todos los medios sociales, puedo asegurar que se trata ahí de una experiencia de la que mujeres y hombres de estirpe popular tienen tanto conocimiento como los escritores, si es que pudieron acceder a los libros, por supuesto, y deconstruir los obstáculos que los separaban de ellos. Y si estamos atentos a esos pensamientos, esas asociaciones que les llegan a los lectores, esas sensaciones experimentadas, esos lazos escondidos que anudan a espaldas de las instituciones, entendemos que la apropiación de textos escritos, o de fragmentos de textos, contribuye de manera relevante a la producción de sentido, a la simbolización de la experiencia, a la integración de la historia personal, a la recomposición de las pertenencias, incluso para hombres o mujeres que se adueñan de ello de manera ocasional. ${ }^{26}$

25 La Traversée des fleuves, París, Seuil, 1999, p. 204.

26 Cf. Nuevos acercamientos a los jóvenes y la lectura, op. cit. 
En esa contribución se encuentra, me parece, lo decisivo de la lectura de libros hoy, en esta época donde a cada persona le incumbe, mucho más que en el pasado, construir su propia identidad y el sentido de la vida. Otros medios de comunicación pueden informarnos o distraernos, pero en el campo de la construcción de sí, o de la reconstrucción de sí, el libro conserva actualmente, en particular a los ojos de los jóvenes, ventajas específicas.

Hoy en día, cantidad de emisiones de radio o de telerealidad, de ficciones televisivas concebidas a medida, les proponen a los niños, a los adolescentes, a los adultos, comentarios de sus experiencias. Y es tal la sed de palabras de los seres humanos que éstos intentan acomodarse a un material a menudo pobre o mediocre para formular sus deseos, sus fantasmas o sus miedos. Pero las confesiones a toda velocidad y exhibicionistas de la telerealidad no nos devuelven el mismo eco que una obra sacada del trabajo lento, en recogimiento, de un escritor o un artista. En el primer caso, estamos más ante un modo de formatear la experiencia que ante el develamiento de una verdad singular. Puesto que decir, transmitir, lo que uno experimenta es una tarea mucho más compleja de lo que parece. No tenemos más que pensar en lo pasmado que nos quedamos tras haber vivido algo que nos ha afectado, incapaces de comunicar cualquier cosa. Todas las sociedades han recurrido, para ello, a mediadores, «traductores» profesionales, narradores, poetas, dramaturgos, artistas, o-en modo distinto- psicoanalistas.

Los escritores son creadores de sentido que se toman el tiempo necesario para darle significación a una experiencia, a un acontecimiento individual o colectivo. Profesionales de la observación -de ellos mismos o del mundo-, en proximidad con un pensamiento sonador, trabajan el lenguaje, lo limpian de clichés (los buenos escritores, al menos). Y este trabajo, psíquico y literario, tendrá resonancias en los lectores. Más aún si les propone no un calco de su propia historia, sino una transposición.

Pues se comprueba con frecuencia que los textos que les «llegan» más a los lectores, que generan una actividad de pensamiento, de simbolización, no son aquellos que les devuelven un simple reflejo de su situación, sino aquellos que les dan una versión transpuesta y 
requieren un movimiento activo de apropiación. ${ }^{27}$ Proceso complejo, más allá de la «identificación» a la cual se le reduce, donde los poderes de la metáfora actúan de un modo notable.

Lo que al principio de la vida el niño trata de captar al interrogar el rostro de su madre, lo que luego explora o teme en los libros, es en gran medida ese ser extraño, inquietante, fascinante, que está en el fondo de él, y del cual ignora muchas cosas, pero que a veces se descubre, se construye, por azar, en una página; ese lejano interior, ese lugar tan íntimo, el más escondido, que sin embargo es el que nos empuja hacia los otros. Allí se encuentra una gran parte del secreto que buscan los lectores, a veces con tanto frenesí; y que otros, en cambio, se esfuerzan por evitar. Pues el arte, la literatura, nos sumergen precisamente en el mundo oculto de la afectividad, fuente de nuestra fuerza de vida. Pero nos proveen de ecos difractados, transpuestos, elaborados, que suscitan no solamente pensamientos sino también emociones, potencialidades de acción, una comunicación más libre entre cuerpo y espíritu. Y la energía liberada, recuperada, apropiada, da a veces la fuerza de salir de un contexto en el que un lector, una lectora, se sentía inmovilizado.

Cuando un lector, una lectora, se desplaza, en un campo u otro de su vida, no se puede contabilizar únicamente un valor añadido «útil» que la lectura le hubiera procurado en forma de saber, de información, o de un mejor manejo de la lengua. También deben considerarse estas reorganizaciones psíquicas; pues es la elaboración de una posición de sujeto lo que está en juego. De un sujeto que construye su historia apoyándose en fragmentos de relatos, en imágenes, frases escritas por otros, de las que saca fuerza, a veces, para seguir otro camino distinto del que todo parecía destinarle.

Estos son algunos aspectos de la experiencia de lectores y lectoras de hoy. Vimos que la lectura es un arte que se transmite más que enseñarse, y que en nuestras sociedades la transmisión en el seno familiar es la más frecuente y la ayudan a producirse, lo más a menudo,

27 Cf. Michèle Petit, Eloge de la lecture, París, Belin, 2002, pp. 59-69. 
mujeres que hacen deseable la apropiación de los libros. Vimos también que desde los primeros momentos actúa la búsqueda de un secreto relativo a la vida más profunda: la de las emociones, de los amores, de los misterios de la vida, de la muerte, del cuerpo sexuado. Vimos finalmente que se produce una construcción o una reconstrucción de sí mismo, y que las obras literarias dan un apoyo fundamental para generar una actividad de simbolización, de construcción del sentido, de auto-reparación.

Notemos de paso que a lo largo de los últimos años, mientras tantos profesores o bibliotecarios perdían el sentido de lo que hacían, otros profesionales redescubrían la contribución irremplazable del arte, de la cultura, al pensamiento, a la vida simplemente: cada vez más psicoanalistas, psicoterapeutas recurren a mitos, cuentos, poesía, obras de teatro para ayudar a niños, adolescentes, a construirse o a reconstruirse, particularmente en contextos difíciles. Por lo tanto, pienso dedicarme en los próximos meses a identificar mejor la contribución de la lectura a esta restauración de sí. Pero esto no es solamente de la competencia de los psicólogos.

Efectivamente, un mediador cultural puede, en ciertas condiciones no intrusivas, proponer objetos capaces de abrir un espacio, un margen de maniobra, para aquellos y aquellas que, debido a su historia, no disponen de un espacio psíquico libre, de un área intermedia. Relatos, poemas, mitos transmitidos por un iniciador, dichos por su vOZ que protege, son algunas veces capaces de construir el equivalente de un vínculo tranquilizador cuando éste hizo falta: pues la seguridad psíquica y la narratividad se revelan en un vínculo recíproco. ${ }^{28}$ Trabajo sutil, que exige a menudo una atención singular, como el realizado en contextos difíciles, incluso violentos, por bibliotecarios, trabajadores

28 Véase por ej. Bernard Golse: «El yo verbal o narrativo se arraiga en parte en la seguridad de los procedimientos de apego pero también, recíprocamente, (...) la seguridad psíquica ulterior depende de la calidad de la narratividad y de la verbalización», (en Serge Lebovici, Le bébé, le psychanalyste et la métaphore, París, Odile Jacob, 2002, p. 45.) 
sociales, voluntarios, profesores, en particular en varios países de América Latina, pero también en el Medio Oriente.

Lo he dicho en otras ocasiones, ${ }^{29}$ cuanto más difícil, violento, insensato, es el contexto, más vital resulta mantener espacios de respiro, de fantasía, de pensamiento, de humanidad. Espacios abiertos hacia otra cosa, relatos lejanos, rostros desconocidos, leyendas o sabidurías. Y un libro, una biblioteca, es eso, antes que nada. Son también espacios de resistencia, para no dejarles el monopolio del sentido, de las narraciones, a los poderes autoritarios, a los fanatismos religiosos o al «orden de hierro» televisivo, para hablar como Armando Petrucci.

Medimos el valor de la profesión de los mediadores: profesores o bibliotecarios. Pero vemos también qué su posición es muy sutil: ¿No es contradictorio proponer o incluso intentar imponer lo que espontáneamente se hurta? ¿No hay una intrusión al intervenir en esos registros sensibles, y aun candentes, que se refieren a lo más íntimo de cada uno, a su identidad, a sus sentimientos, a su cuerpo?

\section{LOS PROFESORES, ENTRE EMOCIONES Y RAZÓN}

Estas preguntas se le hacen con una agudeza particular a la escuela, que, en las sociedades donde la instrucción es obligatoria, es el único lugar al que van supuestamente todos los niños. En la escuela, en muchos países, se estudia la literatura como algo exterior a uno; que no se vive, ni se sufre, ni se siente. En el transcurso de los últimos veinticinco años, en mi país, se ha privilegiado en la enseñanza una concepción instrumental, formalista, enteramente enfocada al dominio del texto -inspirada en la lingüística estructural y en la semiótica, y también en una neo-retórica-, con la voluntad de ser más democrática, más científica. Más a la medida de las exigencias de una sociedad

29 Véase Michèle Petit (2002), «Pero ¿Y qué buscan nuestros niños en sus libros ? , en Lectura sobre lecturas/2, México, Consejo Nacional para la Cultura y las Artes, pp. 9-42. (traducido del francés por Diana Luz Sánchez). 
industrial. Más en condiciones, también, de dar cabida a evaluaciones. El «texto» literario se ha vuelto una máquina que funciona y los alumnos supuestamente adquirieron el saber-hacer técnico, las herramientas capaces de hacerlo funcionar-; y luego se ha vuelto una «forma de discurso» entre otras. De ese modo, curiosamente, cuanto más la escuela se abría a categorías sociales inicialmente alejadas de la cultura letrada, más se imponían una jerga y técnicas de una extrema sofisticación.

Cierto racionalismo puro y duro veía entonces en la emoción al enemigo a vencer y ocasionó una desconfianza hacia toda lectura «identificadora», a la que se redujo de manera simplista al enfoque subjetivo. El temor de ser «poseído» por el libro no estaba lejos...

Estos últimos años, en mi país, mucha gente se interrogó acerca de la deriva tan formalista que prevaleció durante cierto tiempo, y la escuela intentó, mediante diferentes ángulos, encauzar de nuevo hacia la lectura. Por ejemplo, en la escuela secundaria-que uno cursa normalmente entre los once y quince años-, se trató de integrar la lectura personal en la actividad escolar, en particular al incorporar ahí la literatura para jóvenes. Pero profesores, especialistas en didáctica, se preocupan por los efectos de la intrusión escolar en el dominio privado y evocan la voluntad de recuperación de la institución y sus temores con respecto a lo que ésta no domina.

Y de hecho uno oye, con otros pedagogos o especialistas en didáctica, que habría una trayectoria obligatoria que sería la que permitiría pasar de una lectura privada a una lectura crítica. Se entrevé una voluntad de omnipotencia, reverso de un sentimiento de impotencia, un irritamiento frente a esta lectura privada. El temor de esta lectura incontrolable, que no guarda su distancia, se traduce frecuentemente en otra preocupación: se escucha que «un libro no vale más que por las sociabilidades que instituye»-mientras que estos pedagogos notan que los adolescentes generalmente no quieren hablar de sus lecturas. La «buena» lectura es entonces la lectura acompañada, comentada, compartida.

Varios de esos discursos suenan familiares al recordar a los de otras épocas sobre la necesidad de controlar, dirigir la lectura femenina, que nunca gozó de una plena legitimidad. Y nace la sospecha de que el 
miedo a la lectura privada, como a la lectura popular, sea tal vez un miedo a la lectura femenina, un llamado para disciplinar lo que pasa en esos roperos, esas cabañas, esos árboles, esos rincones donde las chicas, pero también los chicos, sueñan dentro de los libros. Y donde se deshacen de su pesada armadura, como la joven descubierta por Martín Garzo en El Capitán Tormenta.

Manguel nota con fineza en su Historia de la lectura: «La inquietud común respecto a lo que podría hacer un lector entre las páginas de un libro se parece al temor eterno que sienten los hombres ante la idea de lo que las mujeres podrían hacer en los lugares secretos de su cuerpo, de lo que podrían realizar en la oscuridad brujas y alquimistas detrás de sus puertas cerradas con triple llave.» 30 Tranquilicémonos: no es sino en la fantasía de los demás que estos lectores se dedican a secretos de alquimistas o a placeres culpables. Quizás se acerquen leyendo, algunas veces, a una inquietante extrañeza: pero sólo concierne a la parte de sí mismo más secreta, más singular y mejor compartida, la de nuestros deseos, que, mediante el trabajo de la escritura, es transfigurada, contenida, mantenida a distancia.

Existe probablemente una contradicción irremediable, o una muy difícil conjunción, entre la dimensión clandestina, rebelde, eminentemente íntima de esa lectura personal, con su fuerte componente de apropiación, y los ejercicios que se hacen en clase, en ese espacio transparente, bajo la mirada de los otros. Entre la ensoñación de un niño construyendo un sentido y la sumisión a la letra, la imposición de una cierta lectura; entre el placer inmediato y el encuentro con textos difíciles, exigentes, y para el profesor, a veces, entre el corazón y la razón.

Patrick Chamoiseau da un ejemplo de ello en Camino de la escue$l a$, en el cual evoca a un maestro austero, tironeado entre sus emociones y las exigencias de la razón que le inculcaron cuando, en el momento de su formación, se le rogó dejar su corazón y su lengua materna -el criollo- en el vestidor. Pero algunas veces ese hombre

30 Alberto Manguel, Une Histoire de la lecture, París, Actes Sud, 1998, p. 37 
rígido, que reprende a los niños por cada giro idiomático, olvida un poco su actitud de dominio: «El maestro leía para nosotros, pero pronto se dejaba llevar, olvidaba el mundo y vivía su texto con una mezcla de abandono y vigilancia. Abandono porque se entregaba al autor; vigilancia porque en su interior seguía viviendo un viejo controlador al acecho, buscando la ocasión para la eufonía desolada, la idea ablandada por una debilidad del verbo (...) El negrito seguía con la boca abierta, no el texto sino los banquetes de placer que el maestro se daba con las palabras.»31

Y es ahí al abandonarse a su placer, ahí donde su propio cuerpo es tocado por las palabras leídas, cuando el maestro transmite el gusto por la lectura.

Todos los días, niños y niñas se convierten en lectores porque un docente, a pesar de la rigidez de ciertos programas, o gracias a la sutileza de otros, hace deseable la apropiación de textos estudiados, e inclusive de obras difíciles, exigentes. Hoy, como en otras épocas, para numerosos alumnos la escuela tiene todos los defectos, pero tal docente singular está dotado con la habilidad de introducirlos a una relación con los libros que no sea la del deber cultural, la de la obligación austera. De suscitar en ellos el encantamiento, pero también el deseo de pensar, cuando él o ella elabora delante de ellos un pensamiento vivo, en movimiento, en vez de aplicar un esquema.

Pero hay una ingratitud co-sustancial a la lectura, así como nos acordamos muy raramente de haber aprendido a leer, olvidamos una parte de lo que debemos a nuestros maestros: siempre siguiendo los pasos del pequeño niño que se apodera de la canción infantil o de la historia que se le propone, que la siente como su propio bien, como algo que «creó», «inventó», mientras que le fue dado. Al hacer entrevistas, me sorprendió a menudo el hecho de que los mismos que hablan horrores de la escuela citan espontáneamente, entre los libros que fueron importantes para ellos, algunas obras que encontraron

31 Patrick Chamoiseau, Chemin d'école, París, Folio, p. 161. Citado en Nuevos acercamientos..., p. 167. 
probablemente en la institución escolar y de las que pudieron apartar fragmentos para su uso privado.

Graciela Montes escribe: «La cultura heredada sólo es útil en tanto puede convertirse en cultura propia, es decir, en tanto puede ingresar a la propia frontera indómita. Y, para eso, tiene que convertirse en experiencia.» ${ }^{32}$ Y también: «Enseñar literatura no puede significar otra cosa que educar en la literatura, que ayudar a que la literatura ingrese en la experiencia de los alumnos, en su hacer, lo que supone, por supuesto, reingresarla en el propio.» ${ }^{33}$ Fragmentos de la cultura oficial, heredada, habían podido ayudar a los lectores que evoqué hace un mometo a formalizar su propia vivencia, a construir su «casa interior», habían entrado en su experiencia personal.

\section{«UNA BIBLIOTECA NO ES SOLAMENTE UN HANGAR DE LIBROS»}

La biblioteca es un espacio radicalmente diferente al de la escuela, percibido por aquellos que la utilizan, desde su edad más temprana, como una tierra de lo posible, un espacio de libertad. Es el lugar por excelencia de estos usos discretos, de estas apropiaciones singulares, que evoqué: y fue al hacer entrevistas con usuarios de bibliotecas cómo me di cuenta de su importancia, cualquiera que sea el medio social. La biblioteca puede ser el espacio privilegiado de una relación con el libro que no se fundamente en las perspectivas utilitaristas de la instrucción, que permita en particular esos tiempos de fantasía de los cuales no debemos rendir cuenta a nadie, en los cuales se forja el sujeto y que, tanto como los aprendizajes, ayudan a crecer y, sencillamente, a vivir.

Como lo dijo Khaled, un adolescente: «La escuela es todo lo que atañe al rigor, nos aporta cosas escolares, la metodología. Mientras que en la biblioteca, somos libres para ver las cosas como lo deseamos. No tenemos a nadie atrás de nosotros para jodernos, leemos lo

32 La frontera indómita, op. cit., p. 54.

33 op. cit., p. 55. 
que queremos.»O Miguel: «Cuando uno es pequeño, tiene la impresión de que se lo imponen todo. Mientras que de lo que uno aprende en la biblioteca, uno puede decir: soy yo quien lo aprendí y nadie podrá decirme: “iApréndetelo!” O este otro adolescente: «Aquí no hay instrucciones. No nos presionan. Aquí tu eres libre. Tomas lo que quieres. Todo depende de ti.» O Daoud: «En una biblioteca pasa una cosa genial, no hay escuela, no hay academia, no hay de que este autor es más grande que el otro. Hay sólo apellidos.»

La profesión de bibliotecario se concibió inclusive diferenciándose de la de profesor, y la idea de controlar a los usuarios, de imponerles lo que sea, repugna a la mayoría de estos profesionales. Una vez iniciado en el funcionamiento de los espacios, se supone que el usuario sabe lo que es bueno para él. Pero se le presupone una autonomía al mismo tiempo que se espera que la biblioteca lo ayude a construirla. Y éste o ésta al que la autonomía le hace falta, o asusta, porque su historia familiar no le ha permitido establecer bien esta área transicional de la que hablaba hace rato, o porque sus referencias culturales están a años luz de las de la biblioteca, éste mismo está perdido, excluido. Deserta los lugares, o se muestra agresivo, o se encasilla en lo que le es familiar. Ciertos adolescentes releen así sin cesar los tres mismos libros, y su trayectoria gira, hasta el día en que dejan de leer. $O$ tienen en una ocasión una experiencia iluminadora, y después aparentemente no encuentran nada.

Otros en cambio dan un salto, como Daoud, que de lector de Stephen King se convirtió, al cabo de los años, en un fanático... de Faulkner o de Kafka: «sufrí los miedos de Stephen King, pero son obras que dejé después, las encontraba demasiado débiles.» Cuando da semejante paso un adolescente que proviene de un medio donde leer no es cosa fácil, es casi siempre porque algún mediador contribuyó a su evolución: de hecho, profesores y bibliotecarios ayudaron mucho a este joven. El eclecticismo que caracteriza a la adolescencia es una fortuna y les da a los profesionales un margen de libertad, de creatividad que puede también explayarse para imaginar pasarelas entre el audiovisual, tan presente en sus vida, y el escrito.

Esto supone un acompañamiento sutil y discreto, pues esta edad es muy sensible a la intrusión. Pero este acompañamiento es decisivo 
en varias etapas de la trayectoria de un lector; al principio, para deconstruir miedos y prohibiciones, para legitimar un deseo de leer, o para revelarlo, luego para abrirse a lo nuevo, ayudar en los pasajes difíciles, de una sección de la biblioteca a otra, y del mundo de los libros de la infancia a universos ampliados, y no solamente a las colecciones hechas a la medida de los adolescentes. Como lo dice ahí también Graciela Montes, «¿Cómo podría transitar un individuo de trece años (...) el camino de la literatura amparada de su primera cultura a la literatura general del mundo si los mediadores no pueden darle algun señal, anticiparle algo del viaje?»34

Más ampliamente, es indispensable insistir sobre la importancia de estos lazos con un mediador -que muy a menudo es una mediadora-, sobre el impacto de esos momentos de encuentro, de esa posibilidad de ser escuchado, a veces a media voz. Del mismo modo que los profesores, los bibliotecarios subestiman el hecho de que contribuyen e influyen, a veces de manera decisiva, en el destino de aquellas y aquellos a los que acogen, en particular por intercambios personalizados. A través de éstos, sin embargo, algunos acceden a un sentimiento de pertenencia, a un reconocimiento vital, como esta joven mujer que dice: «Saber que alguien está ahí, que te escucha... El hecho de tener un cierto lugar en la biblioteca. Que te dicen buenos días, te llaman por tu nombre, "Cómo estás?", "Estoy bien”. Con eso basta... Uno se siente reconocido. Que tiene un lugar. Que está en su casa».

A quienes no pudieron encontrar libros en su casa, ver a sus padres dedicados a la lectura, o escucharlos contar historias, tal encuentro puede también darles la idea de que una relación con los libros es posible. Alguien que ama a los libros, en cierto momento ofrece la oportunidad de tenerlos entre sus manos, de asirlos físicamente. Ese iniciador decontruye lo que parecía un monumento lejano, pomposo, vuelve posible un diálogo con un hombre o una mujer que escribieron hace algunos siglos, o anteayer. En este caso es también el interés

34 Op. cit., p. 113. 
profundo por los libros lo que hace que el niño, el adolescente -y de igual forma el adulto- entienda, en una relación parecida a la transferencia psicoanalítica, puesto que no hay transmisión sin un encuentro emocional, lo que no significa que el mediador deba dar muestra de familiaridad.

Lejos de considerarlos simples técnicos de la información, muchos usuarios temen que los bibliotecarios vean su trabajo convertirse en el de «cajeras de supermercados» y lamentan que no haya más intercambios, como sostiene Hadrien al decir: «Son personas que realmente tienen un potencial, que pueden ayudar, que conocen muchísimas cosas, que han leído muchísimo. Y uno los utiliza como si fueran sustitutos de una computadora. Son gente que verifica códigos de barra; ha de ser muy fastidioso para ellos. Y eso no me parece nada bien (...) Son gente que tiene posibilidades que se desaprovechan por completo. Es una lástima.» $\mathrm{O}$ Malik: «Para mí, lo que más hace falta es el consejo (...) Para mí una biblioteca no es solamente un hangar de libros, es mucho más.»

Ahora bien, actualmente en mi país, varios elementos fueron en contra de esos momentos de intercambio, de esas relaciones personalizadas cuyo papel es esencial, más aún con aquellos y aquellas que provienen de medios poco familiarizados con los libros: la obsesión de la evaluación, fundada en los únicos elementos cuantificables, visibles, controlables; la afición a veces exclusiva por las nuevas tecnologías, que fortalece la representación de la biblioteca como un simple banco de informaciones o de los bibliotecarios como técnicos; y a veces, paradójicamente, la insistencia sobre el papel «social» que tienen las bibliotecas, cuando éste se confunde con las actividades colectivas.

Dentro y fuera de los muros de la biblioteca, existe entonces una urgencia por multiplicar las oportunidades de mediación, rehabilitar la función de dar consejo, con el objeto de que los profesionales (y voluntarios capacitados, ahí en donde el servicio público cuenta con ellos) puedan ayudar a los adolescentes (iy a otros públicos!) a cruzar umbrales, a hacer descubrimientos imprevistos, a apropiarse de metáforas para construir sentido y representar un mundo interior a veces caótico, y hacerlo más tolerable. 
Si hay mediadores que saben bregar para que los libros produzcan menos miedo, si saben lanzar un puente que vincule una biblioteca con un barrio o con un pueblo, los niños, los adolescentes, los adultos querrán agarrarse a algo. A palabras que uno les diga, a trozos de saber, a una historia que se les lea, o que van a descubrir por sí mismos, si no les cuesta demasiado trabajo descifrarlo. Y esto abrirá un espacio donde las relaciones serán menos brutales, como mitigadas, mediatizadas por la presencia de estos objetos culturales. En contextos violentos, una parte de ellos ya no será rehén, una parte de ellos escapará a la ley del lugar, a los conflictos cotidianos. El libro mismo es un mediador, un tercero que se interpone entre nosotros, y abre la posibilidad de compartir, de conversar, de pertenecer a un grupo, a una sociedad, a un mundo, de otro modo que por medio de afectos grupales.

\section{ABRIR UN ESPACIO QUE NUNCA SERÁ COLMADO}

Existen otros intercesores de quienes sería necesario hablar. Y para empezar, de esos profesionales tan a menudo olvidados, los libreros. Sin duda alguna, no todo mundo goza de la oportunidad de tener librerías cerca de su casa, de atreverse a entrar, de disponer de recursos financieros para proveerse ahí. Pero cuando esta suerte se da, desde la edad más temprana, existirá mejor oportunidad para apropiarse de los libros, en el sentido amplio de la palabra, mayor libertad que la de arrastrarse a gatas entre los estantes, de descubrir solito algo que ni los padres, ni los profesores, le han sugerido.

Haría falta también mencionar a los trabajadores sociales, que hasta una fecha reciente eran, en mi país, a menudo reacios a los libros e intimidados, y que actualmente han tomado conciencia y le apuestan al acceso a los bienes culturales para las personas con dificultades. Evoco una vez más a los psicoterapeutas de los que hablaba hace un momento. Pero el mediador, como lo dijo un día Geneviève Patte, itambién puede ser el peluquero! O cualquiera de nosotros que, a veces sin saberlo, abrimos en otra persona un espacio de interrogación, de curiosidad, de ensoñación, que nunca será colmado. Como esta joven, en un libro de Thierry Laget, que le elogia las poesías de Baudelaire a un 
chico; y él, enamorado, se precipita para comprar el libro y trata de penetrar el misterio del ser amado en sus páginas. Pero el misterio se volverá aun más grande: «Estaba desconcertado: la carne estaba ahí, y el verbo, los perfumes, la cabellera, esa feminidad que me turbaba y de la que buscaba la llave libresca. Pero todo estaba ahí representado en una escala desmesurada, inquietante, vertiginosa, y no podía hacer coincidir los versos del poeta con las sonrisas tímidas, los rizos, el perfume indeciso de Catherine.» ${ }^{35}$

Me hace falta decir una palabra más sobre las relaciones que esos diferentes mediadores tienen unos con otros, y por supuesto que aquellas varían considerablemente según los contextos culturales y sociales. En mi país existió durante hubo mucho tiempo la marca, y no ha desaparecido, de una rivalidad, de una oposición entre la familia y la escuela, como si ésta debiera arrancarle al niño la «sombra» de su origen.

De manera parecida, la mayoría de las veces -al menos en Francialos profesores ignoran a los bibliotecarios, mientras que éstos desconocen lo que realizan los profesores, y, a menudo se mofan de ellos imputándoles el poco gusto que los adolescentes tienen por la lectura. Pero cuando existen, en cambio, son preciados los lazos, las cooperaciones, las circulaciones de experiencias entre familias, escuelas, bibliotecas, asociaciones.

Lo anterior con la condición de no mezclarlo todo, de velar por mantener espacios distintos, lugares, papeles, usos diferenciados. Es una suerte que existan espacios diferenciados, cada uno con su propia vocación. Por otro lado, muchos niños se inclinan por que la escuela sea un espacio distinto al de la familia, de la casa, un espacio donde tienen una vida que sus padres ignoran, que se les escapa; y a muchos no les gusta contarles a sus padres lo que ocurre en la escuela: eso forma parte de su vida privada. De la misma manera, no esperan lo mismo de la biblioteca que de la escuela. Y tienen razón.

Y no hay que olvidar esto, que complica un poco las cosas: aunque reproducimos gestos que vimos hacer a nuestros padres, a menudo

35 Thierry Laget, A des dieux inconnus, París, Gallimard, 2003. 
leemos en contra de nuestra familia, de la sociedad, del mundo entero, en particular durante la adolescencia. iSi todo el mundo se pone de acuerdo para que lean, corremos el riesgo de que los niños, y más aún los adolescentes, levanten el vuelo hacia otros placeres! Aquí pienso en una niña, Emilie, que me contaba: «Tenemos como deportes obligatorios la gimnasia, la piscina, y la biblioteca». Cuando la lectura se percibe como un gesto de conformidad, de sumisión, del que hay que dar siempre cuenta, no volver a abrir un libro, o al menos no volver a leer las lecturas prescritas por la familia o la escuela, puede parecer como una toma de autonomía: si muchos jóvenes se resisten a los libros, quizás sea también debido a los esfuerzos por hacerles «tragar» esos libros.

Evoqué a estos niños que se acercaron a la lectura porque estaban fascinados por el misterio de su madre leyendo una novela o conservando con esmero libros que no leía, o de su abuela arrojando su leña para conversar con Dios en una colina; me faltó tiempo para evocar a este chico que creía que su padre hablaba con los libros cuando lo escuchaba caminar en la biblioteca, y tantos otros. Más allá, en la adolescencia o en la edad adulta, no es difícil observar que la búsqueda ávida de un secreto que les concierne profundamente atormenta a numerosos lectores, en caza perpetua, como el escritor Pierre Bergounioux que dice: «Esperé mucho tiempo que el libro que lo explicara todo existiera». ${ }^{36} \mathrm{O}$ como este hombre que cuenta: "Compro libros sin tener siempre el tiempo de leerlos, para no arriesgarme a dejar pasar el que, finalmente, sabría todo de mí. Si lo dejara pasar ise da cuenta!"

Cuando consulto ávidamente cerros de libros para escribir algunas frases, algunas páginas para ustedes, ¿no estoy también creyendo que el libro que explicaría todo está tal vez ahí, entre aquellos que tomo en mis manos con gusto e inquietud ? Pero esta creencia no es tan loca, después de todo: una inmensa parte de lo que los humanos han podido descubrir está ahí, escondida en alguna parte, en los

36 Pierre Bergounioux, La Mort de Brune, París, Gallimard, 1996, p. 117. 
libros, y sólo espera ser animada, revivida. Revivida ya que esas palabras se vuelven carne, gestos, movimientos, y aquí está mi cuerpo animado por lo que encuentro, mis manos que sienten necesidad de copiar un fragmento para apropiármelo mejor, que cortan una cita para pegarla cerca de otra, mis dedos que corren por el teclado, y al final del camino aquí estoy delante de ustedes leyendo en voz alta, gesticulando más de lo necesario, para intentar pensar con ustedes en las intrigas de nuestra condición compartida, de nuestras pasiones, de nuestros temores, de nuestros sueños, y en el extraño objeto que nos reúne.

Muchas gracias.

(Traducido del francés por Raúl Fernández Acosta) 


\title{
El control en la orientación de la lectura
}

\author{
JUAN ROS GaRCÍA
}

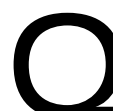

uiero agradecer a la UNAM la invitación a este curso: La lectura, pasado, presente y futuro. Tras varias opciones en la delimitación del contenido se me ha encargado hablar del "control en la orientación de la lectura". El tema es muy interesante. Durante veintiséis años he sido catedrático de literatura española y miles de estudiantes han pasado por mis manos: he tenido que orientar, que sugerir, casi obligar a la lectura de determinados géneros, determinados autores o determinadas obras. Esto ha producido muchas anécdotas en mi vida, como las siguientes:

- Mira, Carmen, este señor es el culpable de que no lleguemos a final de mes por comprar libros.

- ¿Sabe, D. Juan, que mi hijo ha aprendido a gatear haciendo torres sobre los libros de casa?

Pero, volvamos al tema ¿Qué es control? ¿Qué es orientación? ¿Debe haber control en la orientación de la lectura? Y si debe haberlos ¿quién los debe ejercer? ¿Qué ha ocurrido hasta ahora?. ¿Qué debe leer un niño? ¿ un adulto?

Las posturas suelen ser contradictorias:

a) Hay que controlarlo todo.

b) No hay que controlar nada.

c) Ya leerá cuando sea mayor. Esta lectura puede dañarlo en su formación. No está preparado: a un niño no se le permite comer comidas fuertes: callos, cocido, chile. Tampoco se le deja un cuchillo afilado para que juegue. ¿Por qué vamos a dejarle que lea Lolita, Candy, El Capital, Los trópicos, El amante de Lady Chaterley, Sexus, El Extranjero, la Biblia...? Sí, he dicho la Biblia, porque, como veremos, la Biblia ha estado prohibida muchas veces. 
d) La otra postura sostiene lo contrario: es mejor que lea todo lo que quiera; nada le va a hacer daño; si algo le sienta mal, el daño es menor que si no lo leyera; debe predominar la libertad...

Y hay que tomar postura.

Yo recuerdo que, siendo niño, 6-7 años, leía todo lo que mi padre tenía en casa. Cogía sus enciclopedias, sus libros y los folletos que recibía; mi padre, nonagenario hoy, carpintero, es un hombre muy culto. Compaginaba su oficio, con su pasión/vicio por la lectura y su afición al Real Madrid. En épocas económicamente difíciles, como la posguerra española, siempre encontraba dinero para libros y estaba suscrito a lo que se llamaba "Pluma al viento", que hoy llamamos, en España, fascículos. Así leí yo partes del Quijote, Dumas, Salgari. Él dejaba siempre sus fascículos al alcance de mi mano. Y así comencé a leer a Pérez de Ayala: Prometeo, Luz de Domingo, La caída de los limones... Debió pensar que el final de esta obra no era adecuado y lo guardó... Yo busqué y rebusqué y pude terminar mi trilogía.

A mis diez años había leído a Baroja, Unamuno, Balzac, Machado, J. Ramón... y no tengo conciencia de que tales lecturas hayan perjudicado mi formación.

¿Por qué debo leer?

Debo leer porque como ciudadano hay muchos temas que me interesan: temas históricos, políticos, económicos, sociales, culturales. A este derecho mío, reconocido por la Constitución, se corresponde un deber del Estado de facilitarme los medios necesarios. Si hubiese conflicto de intereses es el momento en que tendrían que actuar las Políticas de Información y Documentación.

¿Hay algo que se oponga a mi libertad?¿'Tengo restricciones? ¿Ahora? ¿Aquí?

No siempre ha sido así:

La iglesia y el estado, debidamente aliados, han protagonizado algunas épocas de rigidez y autoritarismo a las que quizá sucedían, de vez en cuando, algún periodo de cierta tolerancia o permisividad, aunque sólo fuese para hacer verdadera la teoría de Wolfflin de que a un periodo de rigidez sucede un periodo de libertad, lo que produce una alternancia entre libertad/normas; entre un periodo apolíneo/y otro dionisiaco. Claro que Wolfflin habla de arte, y no de la Iglesia. 
No voy a hacer un alegato contra la Iglesia.

En España se ha considerado siempre a la Iglesia como defensora y guardadora de la cultura (libros, en conventos y monasterios, archivos, etcétera). No obstante ser esto cierto, Tunón de Lara dice que más bien protegió y guardó lo que le convino... Es lógico, si el Islam le perjudica no va a proteger los libros islámicos. Si algún fiel, incluso perteneciente a la jerarquía eclesiástica, o quizá precisamente por pertenecer a ella, se desmarcaba con algún comentario, pues, excomunión.

Veamos, no obstante algún caso curioso:

El Poema del mío Cid se escribe alrededor de 1340 y se pierde. Es encontrado en el siglo XVIII, por un religioso, Hervás y Panduro. Lo encuentra escondido en la biblioteca del convento, tras otros libros, deliberadamente oculto. La falta la portada y alguna página. ¿Qué ha ocurrido?

Parece evidente que algún fraile lo escondió en el siglo XIV para evitar que fuese quemado. ¿Por qué? En el siglo XIV predomina un concepto teocéntrico del mundo, la autoridad es delegada, viene de Dios, a quien representa el rey, y quien desobedece al rey desobedece a Dios. Por entonces circula toda una serie de romances, el Romancero del Cid, que nos presentan un Cid, altivo, orgulloso, que obliga en Santa Gadea a jurarle al Rey," si fuiste nin consentiste en la muerte de tu hermano" que ante el "Çid hoy me obligas a jurar, mañana me has de besar la mano", se niega a obedecerle."Por besara mano de Rey no me tengo por honrado, porque la besó mi padre, me tengo por afrentado". Así se justifica el destierro del Cid:

Vete de mis tierras Chid, mal caballero probado y no estés más en ellas desde este día en un año. Pláceme, dijo el buen Çid, pláceme dijo de grado, por ser la primera cosa que mandas en tu reinado, tú me destierras por uno, yo me destierro por cuatro... 
Pero el Poema representa un Cid, humano de los ojos tan fuertemientre llorando, tornaba la cabeza y estábalos catando,

Un Cid que se separa de Ximena como la uña de la carne

Que se enternece ante la figura de una niña de nueve años:

Çid, en nuestro daño vos non ganáis nada,

Un Cid que manda al rey los tributos de los pueblos que conquista y que pone bajo su dominio todas las conquistas del reino de Valencia.

Este Çid, en suma, es difícilmente desterrable. Hay que eliminar ese libro... Pero un fraile desobedeció...Siendo joven presencié una quema de libros, me acerqué y como quien no quiere la cosa cogí uno El sentimiento trágico de la vida. La Agonía del Cristianismo. Miguel de Unamuno. Lo guardé en el seno. Hoy está en mi librería.

Igual ocurrió con Fray Luis, con San Juan de la Cruz...problemas con la Iglesia, cárcel, destierros.

En su afán por controlar la orientación de la lectura, el Santo Oficio publicó el Index Librorum probibitorum.

La Inquisición y la Censura son los otros elementos que tenemos que considerar a la hora de enjuiciar el control y la manipulación de la información. Veámoslos.

¿Quién controla o manipula la información? Manipulación según el Diccionario de RAE, $4^{\mathrm{a}}$ acepción "Intervenir con medios hábiles y, a veces arteros, en la política, en la sociedad, en el mercado, etc. Con frecuencia para servir los intereses propios o ajenos".

Manipulación de la información será cuando y siempre que la información sufra alguna intervención hábil o artera, para servir los fines e intereses propios, o ajenos, de quien los manipula, frente a los intereses propios (objetivos) de la información. A nivel coloquial manipulación de la información es cuando ella es retirada, mutilada, cortada, alterada, impedida, ocultada o deformada.

La manipulación de la información atenta contra la libertad de información, atenta contra el derecho a la información y atenta contra la libertad de expresión, temas colaterales y sumamente interesantes, tocados por autores como José María Desantes (Derecho a la Información. EUDEMA), Aurelia $\mathrm{M}^{\mathrm{a}}$ Romero Coloma (Derecho a la 
Información y a la libertad de expresión, BOSCH 1984) o Salvador del Rey Guanter (Libertad de expresión e información y contrato de trabajo, Civitas 1994), ajustando y perfilando hasta dónde llega $\mathbf{L i}$ bertad de expresión e información y sus límites de Concha Carmona Salgado (Edersa,1991) y qué campos abarca La libertad de la prensa periodística de Fernando Conesa (EUNSA 1978).

En general podemos decir que controla, que manipula, el que puede, el que tiene poder. Estos poderes los detentan, o son, la Iglesia y el Estado, y otros poderes fácticos (grupos de presión, económicos, políticos, religiosos), el cuarto poder, la prensa.

Cuando el control de la información es ejercido por el Estado se llama censura. Cuando el control de la información es ejercido por la Iglesia da lugar a los libros prohibidos.

Cuando la relación Iglesia-Estado es paralela y se dan estados confesionales, el control, la censura, los libros prohibidos y las penas y castigos forman un todo. Y así vemos que en los mejores momentos de la cooperación Iglesia/Estado, en España, se llega a la obligación del Imprimatur en todo tipo de libros, incluidos los no religiosos; la censura religiosa y la censura política se aúnan para sojuzgar la libertad de información, restringen la libertad de lectura, de información (en prensa, radio, cine, TV, etcétera) ocupan el puesto de censor (normalmente) un religioso que identificará Iglesia/Estado y se prolongará en una especie de inquisidor

\section{LOS LIBROS PROHIBIDOS.}

Se llaman libros prohibidos porque su lectura pone en peligro de pecar. La lectura prohibida pone a nuestra alma en peligro de perder la fe, y apoyándose en el Derecho Natural la lectura puede estar prohibida para unos y no prohibida para otros, por razones de edad, sexo o cultura.

Los Cánones 1384-1405 del Derecho Canónico, mantienen el Index, y afectan a diarios, revistas, etcétera. 
El Index Librorum Probibitorum, es el catálogo de los libros que la Santa Sede ha condenado por dañosos, y cuya lectura, posesión y conservación está prohibida para los fieles.

El origen se basa en San Pablo (Hechos, cap.XXI, 19) y comienza en el Concilio de Nicea, año 325, y se va afirmando en el de Letrán (1215), y Trento empieza la Contrarreforma publicando el Index librorum probibitorum y el Index librorum expurgandorum

Paulo IV , en 1557, crea el Santo Oficio, lo endurece.

Pío IV 1564, lo suaviza, y se hacen más de cuarenta ediciones del Index hasta 1948, que es la que manejamos con un Index additus Librorum probibitorum usque ad diem 5 jan.1954.

Pablo VI el día 7 de diciembre de 1965 transforma el Santo Oficio en la Congregación para la doctrina de la Fe. El Index se suprime el 8 de febrero 1966 (14 de junio de 1966). Deja de tener valor jurídico. Pasa a tener valor moral, y lleva un prólogo del cardenal español Merry del Val.

Penas que acarrea: la excomunión (canon 2318.1) reservada a la Santa Sede.

Por leer las Sagradas Escrituras tuvieron problemas Fray Luis de León, San Juan de la Cruz, Juan de Avila e Ignacio de Loyola.

Lutero por traducir la Biblia al alemán fue avisado para que rectificase y él puso en la puerta de la catedral sus célebres proposiciones. Fue excomulgado.

La Inquisición española, creada por los Reyes Católicos fue suprimida en 1808.

Esta regla general de no poder leer libros prohibidos puede evitarse sacando el correspondiente permiso en el obispado en que uno resida.

España tuvo un Index especial.

¿Qué libros encontramos en el Index, y por tanto qué libros no podemos leer?

Los Catecismos, cartas de los Obispos, etcétera en que se vislumbraran críticas, opiniones, etcétera sobre las Sagradas Escrituras (es el caso de S. Juan de la Cruz, Fray Luis, etcétera). Y luego gente como Descartes, Sartre, Malaparte, Moravia, André Gide, Boccaccio, Milton, Zola, Balzac, Voltaire, el Diccionario Larouse de 1873, y algún 
curioso "Ensayo sobre las siete partidas" o Teoría sobre la monarquía española" de Francisco Martínez Marina de 1825.

\section{LA CENSURA}

Es el segundo elemento fundamental cuando se quiere controlar en la orientación de la lectura. La censura es la institución o sistema jurídico para controlar la publicidad del pensamiento y de las ideas, mediante el examen previo de los mismos: libros, películas, programas de radio, televisión, comunicaciones telefónicas y telegráficas, etcétera. También se entiende como "la intervención que ejerce el censor gubernativo".

"La censura tiene su fundamento en el peligro que el estado supone entrañaría una libertad absoluta en la manifestación del pensamiento y mira por tanto a la oportunidad del acto que se quiere realizar".

Existe además una censura eclesiástica para los temas morales, que tiene su origen en la Inquisición. No obstante, puede decirse que, en España, ambas estuvieron unidas hasta 1978.

La censura es ejercida por la Administración y previamente a la publicación, afecta a la publicidad, es una actividad restrictiva de la Administración; es una autorización y es discrecional.

Los Reyes Católicos dictaron en 1502 una Real Pragmática por la que se prohibía entrar libros de caballería en las Indias.

Está la Censura a posteriori (inquisitorial) que se lleva a cabo después de la publicación, tal es el caso de La Celestina en el siglo XVIII.

La Censura previa exigía el Imprimatur. Nos tropezamos con casos de censura curiosos, como la Tabla de los logaritmos vulgares en la posguerra española.

Precisamente en la posguerra la censura abarca todos los aspectos: libros, conferencias, etcétera, pues iba dirigida a la política, la moral y costumbres y la información.

La censura política, dimanada del Ministerio de Información y Turismo, procuraba que no entrasen libros de ideología contraria al régimen, que no se publicasen en España ni se difundiesen las obras de 
autores nacionales o internacionales, considerados proscritos, bien por haber muerto (i!) en la guerra civil, bien por estar exiliados. Así Cernuda, Alberti, Sender, García Lorca, por no citar a Marx, Engels, etcétera.

Recuerdo que en 1963 fue detenido un compañero de facultad, por supuesto comunista, que según la prensa tenía en su casa " $E l$ capital, obras de García Lorca, doscientas pesetas y una máquina de escribir". Yo nací con la dictadura, y bajo ella pasé dos terceras partes de mi vida.

Permisos para leer libros prohibidos nos los solucionaba D. Angel Valbuena Prat.

¿Qué hacíamos los jóvenes? Leíamos y ajustábamos nuestras lecturas a criterios formativos, o leíamos y no ajustábamos nuestras lecturas a criterios formativos. En este caso nos arrepentíamos, prometíamos la enmienda y seguíamos leyendo.

Por suerte no siempre los censores estaban muy al día de las publicaciones extranjeras, ni de sus métodos de introducción en España. Así leímos a Miller, Lawrence, Nabokov, y como los autores españoles no se encontraban, entonces leíamos Candy, Lolita, Alex o el amor; Los Trópicos, Sexus y El amante de lady Chaterley, además de las obras que procedentes de México y Argentina, nos hablaban de Lorca, Sender, Machado, Cernuda, Neruda, Heminway, Malraux, etcétera.

Llegamos a la osadía de poder perder, además de la inocencia, si es que la teníamos, la libertad. Pero no se imaginan ustedes los libros que se pueden leer por la calle, en el autobús o en clase envueltos en las tapas de Las Moradas de Santa Teresa.

A la censura política hay que añadir una censura moral. Hay ciertas organizaciones y revistas encargadas de "dirigir, aconsejar, modelar y orientar" la vid intelectual española en el aspecto moral. Una de ellas es Biblioteca y Documentación.

Surgida en Valencia y dirigida por María Lázaro en los años cuarenta, publica una Selección de libros, que llega a alcanzar quince ediciones. En los libros aparecen una fichas sobre obras y autores y se dan consejos morales sobre la conveniencia de la lectura. 
Lo mismo ocurre con Lecturas Buenas y Malas (a la luz del dogma y de la moral), que al enjuiciar a Cela dice: "Ha difundido entre nosotros la llamada literatura fuerte. Su complacencia en los temas sangrientos, morbosos o del hampa, le sitúan muy dentro de las nuevas tendencias tenebrosas de la literatura europea y americana. El Nuevo Lazarillo(debe referirse a Nuevas Andanzas y desventuras de Lazarillo de Tormes)...es triste, desenfadada, repugnante y a veces grosera". Y al hablar de las Novelas Ejemplares de Cervantes dice que "suprimidas las escabrosidades y palabras gruesas que figuran en algunas obras, pueden leerlas los niños mayorcitos que posean alguna formación literaria (de 1 a 15 años)".

La Constitución española, me da (pero no garantiza) la posibilidad de que lea lo que quiera. Por ello debo esforzarme en que se cumpla lo que dice.

Hay otros factores que orientan: editoriales, nivel de vida, la elegancia social del regalo.

Época de las enciclopedias. Reedición de los clásicos. Estanterías. Nivel de vida. Pérez Reverte prepara la última entrega del Capitán Alatriste El Caballero delJubón amarillo, en el mundo del teatro de Lope, Tirso...: Navidad 03. Alfaguara, Planeta, Grupo Z. El País...son ejemplos de cómo las empresas orientan o favorecen la lectura poniendo al alcance de los lectores obras a precios bajos.

Hay otros tipos de control: control a la educación, que obliga a ciertos contenidos, que origina conflictos y problemas en las distintas autonomías.

Igual ocurre con la marginación de las mujeres. A mi memoria vienen los versos de Sor Juana Inés "hombres necios que acusáis..."

Como conclusión diré que mi postura respecto al control, a la censura y a cualquier tipo de coacción, o de manipulación de la lectura, es de rechazo. 


\section{Sobre la mitología bienintencionada de la lectura. Tres apostillas al libro ¿Qué leen los que no leen?}

JuAn Domingo ArgüElles

\section{LA LECTURA, ¿AFICIÓN O HÁBITO?}

español Luis Arizaleta (Pamplona, 1960), fundador y director de una pequeña sociedad que coordina programas educativos municipales de animación a la lectura, FIRA, Fomento de Iniciativas Recreativas y Artísticas, ha publicado un libro que aporta un elemento fundamental al debate sobre el tema de la lectura; este elemento está planteado a manera de pregunta desde el título mismo: La lectura, iafición o bábito? (Madrid, Anaya, 2003).

Incluido en la colección La Sombra de la Palabra, que ha venido publicando obras de suma importancia en este terreno (entre ellas, Bibliotecas escolares, ¿para qué?, de Mónica Baró, Teresa Mañá e Inmaculada Vellosillo; Leer antes de leer, de Teresa Durán; y Lectura, escuela y creación literaria, de Ana María Machado), el libro de Arizaleta discute lúcidamente el planteamiento tradicional que, partiendo de un término canónico en esta materia ("hábito"), ha dogmatizado con frecuencia el concepto de adquisición y práctica permanente de la lectura.

Lo que, con mucha inteligencia y sensibilidad, sostiene Arizaleta es que para hacer lectores existe un camino que pasa por cultivar la afición más que el hábito, pues éste "remite a los conceptos de repetición y costumbre", mientras que la afición se conjuga con inclinación y con disfrute. Más aún: las aficiones "forman parte de lo electivo y su ejercicio está más vinculado a las circunstancias personales que lo están los hábitos". Dicho de otro modo, "el hábito se 
ejercita con rutinaria frecuencia y se interrumpe excepcionalmente: a diario, durante toda una vida laboral, aunque no guste ni siempre ni mucho, acostumbramos a poner el despertador."

La inclinación favorable, en cambio (caminar, reunirse con los amigos, ir al cine, etcétera), "puede ejercerse cotidianamente o no, practicarse con mayor intensidad una temporada, y con menos dedicación en determinada época de la vida”.

Una cosa importante que se desprende del inteligente debate que Arizaleta ha aportado con su libro es que las aficiones no admiten culpas ni reproches. Nadie tiene por qué sentirse mal si un día determinado no realizó su afición. No se trata de cumplir rutinas, sino de desear el placer. Y aquí tendríamos que remitirnos a la primera acepción que el Diccionario de la lengua española, de la RAE (Madrid, 2001), ofrece en la entrada "afición": "Inclinación, amor a alguien o algo". Si el hábito no hace al monje, tampoco es seguro que haga a los lectores más gozosos.

"Al subrayar la importancia de la afición -argumenta Luis Arizaleta- no tratamos de establecer una mera distancia terminológica con el discurso más habitual, de corte canónico: en verdad, nuestro punto de vista sobre la lectura difiere de las actitudes educadoras que hacen especial énfasis en la repetición, en la prescripción de buenos libros y en la trascendental importancia de la más temprana adquisición del hábito lector. Creemos que a la costumbre de interpretar en solitario textos escritos de carácter complejo, se llega en su momento; y, para educar la afición a la lectura, nos parece adecuado pensar más en 'buenas lecturas' que en 'buenos libros'.”

No se equivoca Arizaleta cuando afirma que, una vez clausurada la vida de estudiante, los libros desaparecen del mundo cotidiano para convertirse, en el mejor de los casos, en objetos de culto o signos de prestigio. Y siendo así, siempre nos llevan a sentirnos obligados a decir que leer es imprescindible, aunque entre quienes lo digan, absolutamente convencidos, haya personas que no lean en absoluto.

Todos sabemos y en algún momento de nuestra vida lo decimos, que se debe fomentar el hábito de la lectura desde la infancia, que es preciso que los niños adquieran el hábito de leer. Lugares comunes y discurso reiterativo, dicen Arizaleta y Antonio Ventura, prologuista 
del libro, cuando lo que debería privilegiarse es el sentido optativo de placer, puesto que sabemos también, y la realidad nos lo comprueba cada día, que la cultura libresca no es condición sine qua non para el éxito social, y ni siquiera para el mejoramiento moral. Harold Bloom está convencido de ello cuando afirma que "leer a los mejores escritores no nos convertirá en mejores ciudadanos”. Y conste que lo dice Bloom, lector ávido de libros, a quien no podríamos poner en duda su gusto consuetudinario y su seriedad intelectual.

El diagnóstico de Arizaleta y Ventura deberían llevarnos a reflexionar más responsablemente sobre el asunto; más allá de las mitologías bienintencionadas de la cultura. Haciendo eco del libro de Arizaleta, Ventura explica: "Leer es una práctica que practican muy pocos adultos en este país [España], aunque la mayoría de ellos hable de lo importante y de lo bueno que es leer, y de que la escuela debe desarrollar el hábito de la lectura. Me consta que casi todos los escolares y estudiantes de secundaria han escuchado muchas veces en boca de sus maestros, profesores y, también, de sus padres lo importante que es leer. Quizá con demasiada frecuencia se lo han escuchado a personas que, a pesar de decirlo, no lo practican, pues, en el fondo, no son lectores y lo que les ocurre es que, aunque piensan honestamente que leer es bueno y que la escuela debería desarrollar el hábito de la lectura, ellos tampoco lo han adquirido porque, aunque también escucharon que era bueno leer cuando fueron estudiantes, nadie les descubrió la manera de conseguir ese hábito del que todo el mundo hablaba y sigue hablando. Quizá las cosas serían distintas si todos los implicados en el asunto hablásemos del gusto por la lectura, de la afición a leer".

Ésta es una reflexión que, a mi juicio, no deberíamos desoír.

\section{LA DESESCOLARIZACIÓN DE LA LECTURA}

Hay personas inteligentes, sensibles, capaces, brillantes, que han hecho una carrera importante en las letras y las humanidades o que poseen una reputación de haberla hecho (es decir, que ya la bicieron), a quienes he escuchado decir, en más de una ocasión, que a los niños y a los jóvenes hay que obligarlos a leer, hay que imponerles 
una disciplina sistemática de lectura y glosa para que nuestro país no vaya dando penas por el mundo por la terrible vergüenza de su promedio de medio libro de lectura per cápita y por los últimos lugares en los certámenes mundiales de comprensión lectora. (Hace muy poco, la Organización para la Cooperación y el Desarrollo Económico, OCDE, ubicó a México en el lugar 27, entre las 34 naciones que integran el organismo, en el rubro de capacidad de lectura o habilidad avanzada para leer; lo que esto quiera significar.)

He escuchado a estas personas tantas veces y siempre con énfasis tan vehemente que, en varias ocasiones, he preferido guardar silencio a fin de no dañar la relación cordial con discusiones apasionadas que, como en los temas del futbol, la gramática o la religión, conducen a desavenencias duraderas y, a veces, a heridas de la vanidad que casi nunca cierran. (Y todo porque estas personas no perdonan a los demás el que puedan pensar de ellas que están equivocadas.)

Las personas inteligentes, sensibles, capaces, brillantes, que han hecho una carrera importante en las letras y las humanidades o que poseen una reputación de haberla hecho se ofenden con mucha facilidad si alguien pone en duda los mecanismos a través de los cuales llegaron a ser personas inteligentes, sensibles, capaces, brillantes y con una carrera importante en las letras y las humanidades o con una reputación de tal carrera.

A mí -he escuchado decir, por ejemplo, a una de estas personasmis maestros me vareaban de lo lindo y, gracias a ello, descubrí las maravillas incomparables de los libros. Antes se leía más; hoy los jóvenes necesitan de cierto rigor y de disciplina para que apaguen la televisión y enciendan un libro.

Por eso digo -he escuchado a otra que, por cierto, tiene una obra notable y un prestigio de persona muy inteligente- que hay que encerrar a estos muchachos en el salón de clases y ponerlos a leer y a leer y a leer hasta que adquieran la disciplina de la lectura y nunca puedan abandonar el hábito de los libros.

Lo que olvidan o soslayan estas personas inteligentes, sensibles, capaces, brillantes, que han hecho una carrera importante en las letras y las humanidades o que poseen una reputación de haberla hecho, es que este método, tradicionalmente, ha sido el preferido para 
invitar a leer, y que lo cierto es que, pese a su insistencia, ha conseguido muy pocos convictos. Y eso de que antes se leía más, habría que analizarlo y discutirlo para saber si es verdad o si sólo es la forma políticamente correcta de decir que todo tiempo pasado fue mejor, para alimentar la cálida vanidad de que se pertenece a una época y a una raza (la raza de los lectodinosaurios) hoy desaparecidas.

Este tipo de personas suele olvidar con demasiada facilidad que pertenecemos a una educación que imparte, por sistema, aburridísimas clases de español y de lectura y glosa, y no está muy dispuesta a reconocer lo que sí reconoce el español Antonio Ventura, en el prólogo del libro, La lectura, ¿afición o hábito? (2003), de Luis Arizaleta: "la mayoría de los estudiantes dejan de ser lectores al terminar su periodo de formación e ingresar en el mundo laboral; dicho de otra manera, fueron lectores por obligación mientras vivieron en el mundo escolar o académico, pues sus maestros y profesores les obligaron a leer determinados libros y en muchas ocasiones, también, les mandaron hacer algún trabajo sobre aquellas lecturas".

Recordemos lo que Bruno Bettelheim y Karen Zelan observaban, desde hace más de dos décadas, en su libro Aprender a leer (1981). Estos autores nos llaman a no dejarnos engañar por el hecho de que todo el mundo afirme saber que la capacidad de leer es provechosa. Explican: "Que la gente alabe semejante conocimiento no quiere decir que él mismo se haya convertido en parte de su visión de la vida o que dé dirección a su comportamiento; puede seguir siendo un conocimiento completamente inoperante que se guarda en los recovecos de la mente y al que no se presta ninguna atención en la vida cotidiana”.

Esto es, precisamente, lo que desilusiona a los niños y a los jóvenes en las escuelas y en sus hogares: que los profesores, los padres de familia y, en general, los mayores, digan todo el tiempo que leer el provechoso, que es importante, que es formativo, que es condición del éxito individual y social, incluso que es agradable, pero que los mismos profesores, padres de familia y adultos de todo género, con sus naturales excepciones, practiquen muy poco o nada eso que tanto alaban. 
El hecho de alabar las virtudes de la lectura y aun de enfatizar en exceso los beneficios que nos trae, se convierten en actos hipócritas, en frases vacías, en lugares comunes y, sobre todo, en declaraciones políticamente correctas porque es lo que se espera de la escuela. Se olvida que los discursos sin el ejemplo, las buenas recomendaciones sin la buena práctica de quien las formula, desilusionan a cualquiera y en el peor de los casos lo vuelven cínico.

Los discursos de los políticos, de los maestros, de los médicos, de los obispos, de los curas, etcétera, están repletos de propaganda que constantemente desilusiona y frustra. Cómo confiar en la rectitud de quien pregona honradez y en la primera oportunidad ofrece mordida o participa en arreglos ilegales. Cómo ponerle un pedestal a la moralidad de curas pederastas. Cómo hacerle caso al padre borracho y colérico que nos asegura que beber es nocivo para la salud y malo para la convivencia. Cómo creerle al médico obeso y fumador cuando dice que el consumo excesivo de grasa y el tabaco son malos para la salud. Cómo confiar en el lector pedante, desdeñoso, malhumorado y aburrido que nos asegura que leer nos hace mejores personas; seres racionales más humanos y personas sensibles más racionales. No es así, desde luego, como puede funcionar la lectura en la escuela ni en ningún otro lugar.

Por lo demás, leer en la escuela puede ser sin duda formativo, pero no garantiza legiones de lectores convencidos de que leer les ha abierto un mundo. La escuela se ha empeñado en no romper sus diques y en no quitarse los corsés de lo absolutamente obligatorio. Aun personas inteligentes que pregonan cierta apertura mental en todo, se alarman o se ofenden, si pertenecen al sistema escolar, cuando se habla de salirse del programa y brindar lecciones no de humanidades sino de humanidad.

Es que la escuela es tan importante y tan seria, tan herméticamente cerrada, que con cualquier entrada de aire no falta quienes sienten escalofrío y sospechan que el propósito es socavar su principio de autoridad. Y la lectura es esa especie de ociosidad que, además, introduce en la escuela el complicado problema de evaluar que sólo se soluciona a través de la comprensión lectora y de la glosa, desoyendo 
uno de los derechos del lector por los que pugna Daniel Pennac: el derecho a callarse.

En su ensayo "Estudio versus lectura", Felipe Garrido sostiene que la mayor parte de lo que algún día supimos por el estudio lo hemos olvidado, mientras que, por el contrario, recordamos lo que aprendimos por la lectura. Más aún: cree que "si no se ha aprendido a disfrutar de los cuentos y las novelas, de los poemas y los ensayos, de las ficciones y las obras que difunden las ciencias y la historia, será muy difícil sacar provecho, en nuestras escuelas y nuestras bibliotecas, de los libros para estudiar".

La observación es del todo pertinente, pero también podemos advertir otro problema adicional: el que la "lectura" en la escuela se vuelva, precisamente, “estudio”. Puedo ser más específico: el mayor problema, creo yo, no reside tanto en la distinción o en la oposición entre "estudio" y "lectura", o bien entre lecturas útiles y lecturas por placer, sino más bien en que la escuela convierte todo en materia de estudio, incluso aquello que naturalmente se asocia con el placer.

En el momento mismo en que los libros y la lectura sirven, exclusivamente, para un propósito práctico (presentar un resumen, analizar el lenguaje, contextualizar la época y, finalmente, aprobar el examen), en ese mismo momento, leer deja de ser un acto del todo placentero. Lo que sucede es que son muchos los defensores del papel de la escuela como un ámbito disciplinario (es decir, donde se adquiere orden, rigor y método), y muy pocos los que creemos que la institución escolar debe alejarse lo más posible del claustro clerical o militar y abrirse y participar en una cultura donde el placer no sea visto con reprobación o con desconfianza. El problema se agrava cuando el profesor que no goza con la lectura se convierte en guía y por supuesto en árbitro de los lectores en la escuela.

Desde mi punto de vista, el problema no reside en los programas de lectura, sino en la rigidez (iba a escribir frigidez) de los procedimientos de la institución escolar para poner en funcionamiento esos programas de lectura. Mientras la lectura no sea un espacio al margen de los sistemas de evaluación, la escuela no tiene muchas posibilidades de formar verdaderos lectores. Parafraseando a Ivan Illich, por principio de cuentas habría que desescolarizar la lectura, aunque 
esto ponga en crisis (es decir, etimológicamente, en punto decisivo) el papel tradicional de una institución, la escuela, cuyo propósito, en la Edad Media, era el de preparar convenientemente, con reglas rígidas, a los aspirantes al sacerdocio. En la época moderna, ese propósito se ha dirigido a preparar convenientemente a los aspirantes al ámbito laboral. Un lector que no obedezca austeridades en el disfrute más íntimo y que responda más bien a inclinaciones sibaritas (que se vuelven críticas de su situación y de su entorno), pone en cuestionamiento, en ese mismo instante, las reglas estrictas de la conveniente preparación.

En este punto creo que no es gratuito señalar que aunque la fallida interpretación del saber que hay en los libros puede engendrar pedantes y fatuos insoportables, una buena parte de los que leen por placer llegan victoriosamente a la otra orilla: están al margen de cánones, prescripciones y rígidas obediencias: la lectura los vuelve peligrosamente independientes, inoportunamente críticos, razonablemente incrédulos. Se vuelven, como dijera Vargas Llosa, conspiradores y corrosivos permanentes "de todos los poderes, que quisieran tener a los hombres satisfechos y conformes".

En su brillante panfleto radical Aviso a escolares $y$ estudiantes (1995), Raoul Vaneigem tiene razón: "Que la infancia haya caído en la trampa de una escuela que ha matado lo maravilloso en lugar de exaltarlo, indica suficientemente lo urgente que es para la enseñanza, si no quiere hundirse aún más en la barbarie del hastío, crear un mundo en el que esté permitido maravillarse".

Para Vaneigeim, el diagnóstico sobre el actual papel de la escuela es grave: "Ningún niño traspasa el umbral de una escuela sin exponerse al riesgo de perderse; quiero decir, de perder esa vida exuberante, ávida de conocimientos y maravillas, que sería tan gozoso potenciar en lugar de esterilizarla y desesperarla bajo el aburrido trabajo del saber abstracto".

Y es que parece que para que la escuela sea escuela, tiene que ser, por principio, aburrida. Para que sea formativa, debe ser tediosa. Para que nos deje una cicatriz de beneficio, tiene que doler. Así ha sido, tradicionalmente, la lectura en la escuela: una lectura que sólo de manera excepcional ha conseguido formar lectores y que las más 
de las veces los ha alejado, literalmente, de las lecturas que no sean aquellas obligadas para aprobar un examen.

En su libro Leer y escribir en la escuela: lo real, lo posible y lo necesario (2001), Delia Lerner acepta que "la desnaturalización que la lectura sufre en la escuela ha sido puesta en evidencia en forma irrefutable", y aunque sostiene que "al poner en tela de juicio la situación de la lectura en la escuela, no es justo sentar a los maestros en el banquillo de los acusados porque ellos también son víctimas de un sistema de enseñanza", de todos modos espera que "en ciertas condiciones, la institución escolar puede convertirse en un ámbito propicio para la lectura", y que "estas condiciones deben crearse desde antes de que los niños sepan leer en el sentido convencional del término”.

El mito de que la escuela debe doler es otro más de los conceptos equívocos en que se funda una pedagogía ritual de la competencia para el mayor rendimiento y que muchas veces sirve, como bien lo definió Ivan Illich en La sociedad desescolarizada, como "un puente hacia la nada".

Lo que frustra a un potencial lector respecto de esta pedagogía es que la lectura de libros no le sirva para nada. Hay tantos ricos sin lecturas, tantos profesionales que no leen sistemáticamente, tantas personas exitosas a quienes no se les ocurriría tomar un libro ni siquiera en el aeropuerto o en la playa, hay tantos ejemplos así, que el discurso de la utilidad de la lectura en la escuela no puede ser sino otra de sus contradicciones. Leer, sí, pero ipara qué? Para aprobar un examen, desde luego; para escribir una glosa y pasar una materia; para recursar un extraordinario, etcétera. Pero ¿cómo admitir que nos sirve para algo aquello a lo que no se le ve ninguna utilidad práctica?

En realidad, no es la escuela como institución la que ha conseguido inocular el virus de la lectura en un sector de los estudiantes, sino el profesor como individuo que comparte no sólo algo de lo que sabe sino también mucho de lo que es. Porque, como alguna vez lo dijo el autodidacta Juan José Arreola, "el verdadero maestro no es depósito de conocimientos estancados, no es el muro impenetrable y macizo que detiene las aguas en la represa, sino el vertedor en demasías de lo que en su alma es plenitud. Maestro es el hombre henchido 
que desborda, si no sabiduría, afán de comprender el mundo y hacerse comprensible a los demás".

Sólo bajo esta premisa, la escuela puede conseguir algo más que alumnos y, tal vez, lograr también algo más que lectores: personas que tengan la suficiente distancia y la suficiente cercanía como para desear la lectura de un libro cuyo placer no nos puede ser aportado por ninguna otra experiencia, pero, asimismo, sin necesariamente despreciar todos los demás placeres que nunca, jamás, pueden sustituirse con la lectura de un libro.

\section{LOS BENEFICIOS CULTURALES DE LOS NO LECTORES}

¿Cuántos libros leyeron Ana de Codorniú, Federico Paternina y René Barbier? ¿Cuántos libros ocuparon el tiempo de Louis Armstrong? ¿Billie Holiday, tenía biblioteca? Son preguntas simples cuyo propósito humildemente cuestionador-que ni siquiera aspira a la provocación- puede irritar a más de uno.

Sin embargo, aunque despertemos el sagrado escándalo de algunos, tenemos que ser sinceros y reconocer que a muchos otros nos tiene muy sin cuidado si Codorniú, Paternina, Barbier, Armstrong y Holiday eran o no lectores. Nos bastan las maravillas que produjeron para saber que son benefactores de la cultura incluso si no hubiesen tenido contacto estrecho con los libros.

¿Qué importa si leyeron pocos o muchos libros, o si no leyeron ninguno, si a cambio nos entregaron sus extraordinarias creaciones vitivinícolas y musicales? Cuando bebemos una copa de Codorniú, Paternina o de cava Barbier; cuando escuchamos las maravillas de Satchmo o de Lady Day (y más aún si las escuchamos mientras bebemos una copa de Codorníu, Paternina o de Barbier), ¿pensamos realmente en algún momento si los creadores de tan extraordinarios dones eran lectores? Si respondo, nada más por mí, diré que no.

Pero para no caer en parcialidad maniquea, y para que no se me acuse de establecer esta relación únicamente con personalidades de la cultura popular, podría formular la siguiente pregunta, aún más provocadora para quienes así deseen considerarla: ¿Cuántos libros 
leyó Mozart? ¿Le importaban más los libros que el billar? En su biografía casi no existen huellas de que haya sido un gran lector. Aunque no faltarán los que digan que si Mozart hubiese leído más libros habría sido, seguramente, un mejor músico. ¿Cómo pueden saberlo? Mucho más probable es que nada hubiera podido hacer mejor a Mozart, que no sólo siempre es mejor sino que, como dijera Rossini, es el único.

Hay quienes están convencidos de que leer es indispensable para vivir, y podemos aceptarlo, en nuestra calidad de lectores, pero no debemos extremar conclusiones al grado de pensar que los que no leen están muertos o tienen el espíritu en agonía. Podemos comprender a Kant cuando afirmaba que "una lectura amena es más útil para la salud que el ejercicio corporal", pero los deportistas tienen todo el derecho del mundo a no estar de acuerdo con Kant.

$\mathrm{Al}$ igual que Schopenhauer, Marcel Proust, gran lector además de gran escritor, era mucho más razonable sobre este asunto: "La lectura -decía- se encuentra en el umbral de la vida espiritual; puede introducirse en ella, pero no la constituye". En palabras prosaicas, digamos que leer es un camino, y que, como todos los caminos, nos conduce a alguna parte, que puede ser luminosa o lóbrega, pues como pensaba Alberto Moravia, "un libro no es un libro, sino un hombre que habla a través de un libro".

Lo que sucede es que hay tantas opiniones enfáticamente favorables sobre el libro, tantos pensamientos de concentración noble sobre el asunto que este unánime resplandor siempre nos fuerza a querer repetir, con un énfasis mayor, opiniones contundentes que abisman en la barbarie a todos aquellos que no tienen un libro en la mano. Sobre este asunto se exagera constantemente, y ninguna de estas exageraciones ha conseguido que se ganen adeptos para el libro; antes, por el contrario, se ha producido el fenómeno inverso.

Alguna razón tendríamos que concederle al comediógrafo español pasado de moda don Jacinto Benavente cuando asegura que sólo algunos escritores aumentan el número de lectores y que los más tan sólo aumentan el número de libros. Se pueden decir muchas cosas nobles sobre el libro (por ejemplo, que nos hacen libres o que nos guían; que constituyen el andamiaje de la cultura; que hacen aumentar nuestra 
inteligencia, etcétera), pero el decirlas no aumentará automática y masivamente la inclinación hacia la lectura. Lo que se olvida o casi nunca se dice es que el sentido de los libros no termina en los libros mismos, sino en que nos sirvan para pensar y sentir por cuenta propia, más allá de los libros. Kafka siempre tendrá razón: "Un libro ha de ser un hacha para romper el mar helado dentro de nosotros". Ese mar helado que nos lleva a suponer, a muchos cultos, a muchos eruditos, a muchos lectores ávidos, que los que no leen ni escriben no son nada o son poco menos que nosotros, que nuestras prácticas culturales son superiores a las de los demás aunque a diario estemos disfrutando de los beneficios culturales que los no lectores nos regalan todos los días y a cada instante.

No estoy diciendo que no deba hacerse nada para que los demás tengan acceso a las maravillas de la lectura. Todo lo contrario. Pero lo que sí propongo es que el discurso a través del cual se invite a leer sea menos enfático, menos dogmático, más tolerante y más cordial. Y, sobre todo, que no se monte sobre el ruido, pues a veces suele olvidarse de manera increíble que uno de los peores ambientes para la lectura es aquel donde prevalece el ruido. 


\title{
La lectura en los tiempos de Internet
}

\author{
ElSA MARgarita RAMÍREZ LEYVA
}

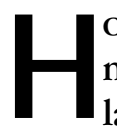

py, en los inicios del siglo XX, podemos considerar que Internet narca un hito en la trayectoria de las tecnologías utilizadas por a humanidad para informar e informarse, para escribir y para leer. Se trata de un medio que tiende a modificar las formas de representación y las prácticas sociales fundadas en el modelo cultual libresco que dio lugar a los modelos que nos anteceden para la producción, preservación, transferencia y uso de la información. El creciente enraizamiento de Internet en el sistema social de comunicación es propiciado no sólo por las características de la tecnología sino también por la intervención de las fuerzas económicas y políticas, las cuales inducen, de manera importante, a crear nuevas utilidades y, por tanto, a su arraigo, como señala Lledó: "nada es producto de la necesidad, sólo la utilidad determina su posibilidad y su realidad. El Rey [la autoridad] es, por eso, el árbitro y dominador de ese espacio social, y es él quien determina el contenido de la utilidad." Entonces podemos decir que la forma, la función y el estatus simbólico de los objetos escritos, corresponden a las leyes que constituyen los modelos de cada época y son transmitidas por los aparatos institucionales que, en su conjunto, socializan, a la vez que modelan la representación y determinan prácticas sociales de producción, consumo y también de comunicación. Además, determinan las clases sociales y las relaciones entre ellas.

1 Emilio Lledó. El surco del tiempo. Meditaciones sobre el mito platónico de la escritura y el tiempo. $2^{\mathrm{a}}$ ed. Barcelona: Crítica, 1992. p.47 
Puesto que la institución bibliotecaria es uno de los espacios de socialización del libro, así como de prácticas de lectura y de modos de informarse, y puesto que ahora Internet representa un nuevo espacio de socialización para la producción, transferencia y uso de información textual, considero oportuno empezar a analizar los efectos que está produciendo el medio digital en las prácticas lectoras de nuestras comunidades. $\mathrm{Al}$ respecto, encuentro en la tesis de Ilich un sustento para reflexionar la lectura en el momento actual en que Internet coloca al libro como un medio más para la lectura:

La lectura libresca de esta época puede reconocerse ahora claramente como el fenómeno de una época y no como un paso lógicamente necesario en el progreso hacia el uso racional del alfabeto; como un modo, entre varios, de interacción con la página escrita; como una vocación particular, entre muchas, para ser cultivada por algunos dejando otros modos a otros. Pero la coexistencia de diferentes estilos de lectura no es un fenómeno nuevo. ${ }^{2}$

En efecto, también en la actualidad las prácticas de lectura en libros coexisten con las incipientes modalidades de lectura que empiezan a vislumbrarse por las innovaciones en el medio digital, y a la vez por las condiciones del modelo cultural, económico-político que favorece las posibilidades tanto como las capacidades para acceder a determinados modos de leer. Como sabemos, la revolución del texto electrónico, es como señalan Chartier y Hébrard: “[...]al mismo tiempo una revolución de la técnica de producción y de reproducción de textos, una revolución del soporte de lo escrito y una revolución de las prácticas de lectura."3 Por consiguiente, las innovaciones, por un lado la computadora como soporte y por el otro la pantalla y el hipertexto, irrumpen en el orden impuesto por la página impresa e imponen una nueva estructura, géneros literarios, es decir una forma distinta de representar el mundo al amalgamar en un hipermedio los

2 Iván Ilich. En el viñedo del texto. Etología de la lectura: un comentario al "Didascalicon" de Hugo de San Victor. México: FCE, 2002. p. 9-10

3 Anne-Marie Chartier y Jean Hébrard. La lectura de un siglo a otro. Discursos sobre la lectura (1980-2000). Barcelona: Gedisa, 2002. p. 199 
diferentes medios de que antes se servía. Hoy la textualidad electrónica interviene tanto en la escritura e imágenes como con los sonidos, pero Internet introduce innovaciones para el proceso, acceso y transmisión de la información. Por consiguiente, el medio digital dará lugar a cambios en las prácticas para escribir y leer instauradas por el libro.

\section{INTERNET EN LAS REPRESENTACIONES Y PRÁCTICAS DE LA SOCIEDAD CONTEMPORÁNEA}

Internet, por sus características, representa la realidad en modos de soporte diferentes a los tradicionales. Al respecto, de acuerdo con la teoría de las representaciones sociales ${ }^{4}$ éstas pueden considerarse como sistemas de valores, ideas, conocimientos manifestados en prácticas que permitan que los individuos se orienten y adapten a su entorno social; son guías para la acción. Por otra parte, las representaciones dotan a una colectividad de códigos para la comunicación e interpretación de los diferentes componentes del mundo. En relación con lo anterior, Flament afirma que las prácticas sociales son una especie de interface entre circunstancias externas, a la vez que prescriptores internos de la representación social; es decir, comportamientos globales que evolucionan para adaptarse a los cambios de circunstancias externas. ${ }^{5} \mathrm{El}$ aspecto social de las prácticas proviene de un diálogo permanente, pues son construidas, a la vez que transformadas por el flujo de las interacciones personales establecidas de manera vertical y horizontal, y son también apropiadas por los grupos o individuos; o dicho de otra forma, integradas a su sistema de valores, creencias y normas. ${ }^{6}$

$4 C f r$. Serge Moscovici. http://www.nsu.ru/psych/Internet/ mosc1.htm

5 Claude Flament. Estructura, dinámica y transformación de las representaciones sociales. En Prácticas sociales y representaciones / ed. Jean-Claude Abric. México: Ambassade de France, Coyoacán, 2001. pp. 33-52.

$6 C f r$. Jean-Claude Abric. Representaciones sociales: aspectos teóricos. En Prácticas sociales ... Ibídem, pp. 7-32 
El mismo autor considera que en la formación de las representaciones interviene lo social a través de:

- el contexto en donde se sitúan los grupos; por la comunicación que establecen los grupos o individuos;

- el bagaje cultural que determina las formas de aprehensión;

- los códigos, valores e ideologías relacionadas con posiciones, y

- las características de los grupos de pertenencia.

Entonces Internet al constituirse en sí mismo en un circuito de comunicación escrita, oral-visual, con las cualidades propias de la tecnología actual: rapidez, tiempo real, interactividad, más las posibilidades de edición y comunicación, representa al mundo de hoy como capaz de transformar el sistema social de comunicación del modelo social del futuro próximo, y por consiguiente las prácticas sociales de comunicación .

Lo anterior se puede encontrar plasmado en el Plan Mundial de la Sociedad de la Información, el cual propone que todas las aldeas estén interconectadas a la red para el año 2025 , con el fin de proporcionarle servicios a la población a través de telecentros con acceso a Internet, en áreas como salud, educación, economía, gobierno. De esta manera Internet será parte del equipamiento y del consumo, y posiblemente más que el libro, pues sabemos que para muchos ciudadanos éste sigue siendo un objeto extraño.

Para mayor énfasis en cuanto al arraigo de Internet en los espacios, en las formas de representación y prácticas sociales, observamos que las fuerzas sociales y económicas nos están conduciendo a la "realidad virtual”, pues cada vez es mayor la presión por estar representados en la red en formato web constituido por información en forma de texto, imagen y sonido. A través de Internet, el público se apropia de esa porción de la realidad, situación que abona para la formación del imaginario colectivo con base en el poder y la libertad de ese medio. 


\section{LOS ELEMENTOS DE VALORIZACIÓN EN INTERNET}

La sociedad contemporánea valora determinados factores que encarna Internet. En función de ellos crea procedimientos y comportamientos para cumplir con las condiciones que ahora se privilegian. Entre éstos tenemos:

\section{El tiempo y el espacio}

La sociedad actual ha llegado a hacer del tiempo un valor económico pero que se extiende a otros ámbitos de la vida personal, incluidas las relaciones interpersonales. Es decir, se fortalece el culto a la rapidez, el que incluso es considerado un factor de calidad por el que las personas, las máquinas y los procesos que logran reducir los tiempos son calificados en un alto nivel de eficiencia, y lo contrario es considerado obsoleto.

Además entre los valores asociados están la actualización, la exactitud, la brevedad de la información y la facilidad para recuperarla. Estos valores conforman en el texto características que obligan a abreviarlo y a establecer una serie de conexiones que favorecen la lectura rápida para obtener y transferir información, a la vez que se la transforma en producto que produzca un máximo rendimiento y beneficio.

\section{La interactividad y el acceso}

Otra de las características que empieza a ser valorada como una de las cualidades del medio digital es la interactividad entre individuos, el texto, las imágenes fijas y en movimiento y, además, el sonido. La interactividad en el texto la encontramos en el hipertexto. En esta nueva estructura el contenido textual ya no sólo cobra vida a través de la lectura; ahora la manipulación que se logra por medio de la mano que controla el ratón nos dirige al interior de los textos para recomponerlos de acuerdo con nuestro interés. Así, el orden establecido en la página de un libro ya no será el mismo en un hipertexto, aun cuando hasta el momento continuemos atados a la página. Sin embargo, en la pantalla la página se convierte en metáfora y acaba con el maridaje del texto con su tradicional receptáculo físico. Conforme el lector 
domine las técnicas hipertextuales empezará a romper las estructuras propias del medio impreso y a crear nuevas formas textuale, que acarrearán otras modalidades de lectura. Sin duda la interactividad, la posibilidad de acumular, integrar, actualizar, modificar, diseñar y transferir información son propiedades del medio digital, todo lo cual ha dado lugar a una sobrevaloración de Internet, pues permite ganar terreno en diferentes ámbitos (educativo, productivo, científico y de entretenimiento).

Si bien es prematuro considerar que Internet es una revolución en la cultura escrita, pues el documento digital conserva las características del texto impreso, por lo mismo podríamos decir que estamos en un periodo similar al del incunable, sería factible considerarlo como un incunable digital o electrónico, un periodo de transición. Por lo que hemos visto hasta ahora esta tecnología de la información y la comunicación seguirán evolucionando, como en su momento sucedió con la imprenta, por tanto cabe suponer, tomando las experiencias de antaño, que las prácticas de lectura y escritura, podrán estar dominadas, en el futuro, por el orden que imponga la textualidad digital. En efecto, las innovaciones de la textualidad digital para representar, sintetizar y acceder al conocimiento, pueden dar lugar a lenguajes y estilos literarios diferentes de los que hasta hoy ha establecido el texto impreso, e impondrán otras normas para leer, y, en suma, apropiarse de los contenidos.

$\mathrm{Al}$ respecto Ramiro Lafuente, ${ }^{7}$ al referirse al "libro electrónico", señala que éste se denota como un producto tecnológico cuyas características ya no aluden a los significados del libro impreso sino únicamente se refieren a algunas de sus cualidades, en particular a las relacionadas con la conservación, la estructuración y la sistematización de enunciados textuales. El web, prototipo del documento digital, es un espacio de textos digitales donde el proceso de incorporación de nuevos textos se realiza constantemente; lo que quiere decir

7 Ramiro Lafuente López. En el umbral del cambio: las tecnologías de la información y la comunicación. México : UNAM, CUIB, 1997. p. 23 
que no existe en ese medio, por ahora, una estructura que fije de manera permanente la información, lo cual es considerada una cualidad, pues implica la actualización permanente. El lector interesado es quien decide qué y cuánto tiempo puede conservar la información. Así, lo único que podemos considerar permanente es la presencia misma de la web.

Esta necesidad de actualización constante nos podría llevar a privilegiar el acceso más que la posesión. Por un lado está la rapidez con la que la nueva información hace obsoleta a la anterior; a lo cual se suma, la idea generalizada de que en Internet es posible obtener información de cualquier lugar, desde cualquier punto del planeta en donde se encuentre un equipo interconectado, lo cual ciertamente disminuye la necesidad de poseer el objeto físico. Así, vemos que las bibliotecas suprimen colecciones impresas por servicios de información que venden el acceso a los medios en formato digital.

En suma, esta tecnología electrónica no sólo modifica las formas físicas en las que se plasma, accede y comunica el conocimiento y la información, sino que también determina los valores sociales relacionados con los modos de apropiación de los contenidos textuales; es decir interviene en el acto de leer.

\section{LA LECTURA EN LOS TIEMPOS DE INTERNET}

Cada una de las formas físicas en donde están inscritos los textos manuscritos o impresos establecieron reglas para su lectura -no siempre explicadas-, pero éstas más bien fueron determinadas por las características del formato. En la pantalla el texto se convierte en una relación de fragmentos en la cual existen conjuntos visuales y maleables que están a disposición del lector, quien a la vez toma el lugar del autor, lo cual crea una interacción diferente de relaciones cuyo proceso mental se coloca en la pantalla que se hace visible al ojo. Es decir, la mente o pensamiento del lector se reproduce en el medio digital, crea nuevas formas de organización y visualización. 
Las condiciones sociales actuales exaltan la valoración de las características de Internet antes mencionadas y repercuten en la concepción de la lectura. Al respecto identificamos las siguientes variantes respecto de la cultura libresca:

\section{La disfuncionalidad de la lectura}

Sabemos que la lectura en estos tiempos de Internet está pasando por circunstancias que podríamos denominar paradójicas, pues por un lado aumentó el número de la población alfabetizada y el porcentaje de ciudadanos con educación básica. Además tenemos casi doce siglos de lectura libresca, y sin embargo, en pleno siglo XXI, son pocos quienes llevan a cabo la práctica cotidiana de leer libros, como senala Jitrik, se lee mal, poco y lecturas que no corresponden. ${ }^{8}$

Por otra parte un porcentaje de jóvenes que han concluido casi nueve años de educación básica, no comprenden, ni pueden darle sentido a lo que leen a causa de dificultades en sus habilidades de lectura. En buena medida esto se debe a sistemas pedagógicos que han hecho de la lectura una práctica para la acumulación de datos e información y también se ha hecho de los libros meros recipientes de datos para ser repetidos, sin que exista el análisis. De este modo se favorece la pereza intelectual, pues en realidad es deficiente la transmisión del deseo de saber, de investigar, de favorecer la curiosidad y asimilar la esencia de los conocimientos; lo que quizá convierte a las bibliotecas escolares en prescindibles, al menos en la mayor parte de las escuelas de países en desarrollo. Y la biblioteca pública convertida en la extensión de la escuela, representa esa lectura utilitaria que sólo sirve para cubrir el acto temporal que implica la lectura obligatoria como sinónimo de "estudiar".

Entre quienes no han incorporado una práctica de la lectura cotidiana se encuentran tanto grupos ubicados en una situación económicamente privilegiada como aquellos que viven en pobreza extrema. Dicho de otro modo, existen algunos que no leen porque no

8 Noé Jitrik. Lectura y cultura. $3^{\text {a }}$ ed. México: UNAM, 1998. p. 11 
pueden, y otros que no leen porque no quieren. En esta situación convergen individuos de todas las clases sociales y de todos los niveles de educación, género y edad. Sin embargo estos diferentes públicos pueden llegar a coincidir en el acceso a los medios masivos de comunicación: televisión, radio, e incluso, podrían llegar hasta acceder a Internet, y muy posiblemente todos esos grupos lectores y no lectores quieran y puedan usar Internet. Sabemos que en este momento existen comunidades en donde no cuentan con bibliotecas pero sí con un telecentro o con maneras de conectarse a Internet.

Entonces el problema no es Internet. A la luz de las nuevas exigencias económicas y políticas nos percatamos de que es un modelo cultural el que ha favorecido sistemas tanto pedagógicos como culturales basados, algunos de ellos, en concepciones sobre la lectura que distorsionan los métodos para crear una verdadera afición por ella ; es decir, que privilegian el aspecto utilitario, temporal, relacionado con prácticas sociales de lectura más bien asociadas con actividades productivas. Todo lo cual no tendría porqué ser negativo, si a la vez enfatizara la necesidad de establecer la práctica de una lectura cotidiana de textos que vaya más allá de los especializados y desarrolle también mejores capacidades, además del mayor capital lingüístico que requiere la lectura crítica y creativa. Al parecer este problema de la lectura utilitaria es el que preocupa a la OCDE, pues encontramos algunas precisiones al respecto en sus parámetros de evaluación.

\section{Los nuevos parámetros de evaluación de la lectura}

En estos tiempos de Internet, la lectura al estar involucrada en el uso productivo de las informaciones se ha convertido en motivo de atención para la Organización para la Cooperación y el Desarrollo Económico (OCDE) que a través del Programa para la Evaluación Internacional de Estudiantes (PISA), evalúa periódicamente, desde el año 2000 y en lo sucesivo cada tres años, las capacidades de lectura, y también de matemáticas y ciencias de los estudiantes que concluyeron la educación media, pertenecientes a 41 países miembros.

La OCDE estructuró su instrumento de evaluación en cuatro situaciones de lectura determinadas que son: 
1. Lectura para uso privado o personal. Aquella que se hace con intereses particulares como desarrollo personal o curiosidad y como parte de las actividades de ocio y entretenimiento.

2. Lectura para uso público. La que se hace en actividades públicas como informes o ponencias; es decir, en voz alta y para compartir.

3. Lectura para el trabajo. Aquella que sirve para hacer, producir y está relacionada con tareas inmediatas.

4. Lectura para educación. También denominada didáctica o escolarizada. Es considerada como una lectura para adquirir información y parte de una actividad de aprendizaje donde los textos son seleccionados por el profesor y los contenidos están diseñados específicamente para la instrucción. ${ }^{9}$

Los gobiernos de casi todos los países, o por lo menos los que forman parte de la OCDE, han emprendido programas oficiales para subsanar las deficiencias educativas y cumplir con las exigencias de la evaluación de este organismo. En México tenemos el "Programa hacia un país de lectores" que, al igual que en otros países, es más bien un conjunto de acciones dirigidas a superar la calificación que nos coloca entre los últimos lugares del tercer grupo, conforme a los parámetros de PISA 2000. Además de este programa tenemos también el de Sociedad de la Información, el cual incluye el desarrollo de habilidades informativas de los ciudadanos que necesitan de capacidades lectoras superiores: análisis crítico, selectividad y transformación en conocimientos nuevos.

\section{La lectura en el nuevo mercado de consumo}

Otro aspecto derivado del nuevo orden económico denominado globalización es el relativo a las nuevas leyes del mercado, de las cuales no escapa la lectura. Las empresas multinacionales están logrando un apoderamiento del mercado de bienes y servicios de información y de los medios de comunicación impresa digital, además de los medios

9 OCDE. Knowledge and skills for life. Firts results from PISA 2000. París: OECD, 2001. p. 75 
masivos: radio, televisión, música, etcétera. Tales empresas han adquirido también casas editoras de gran tradición que habían logrado mantener un equilibrio entre la calidad y las ganancias económicas, pero ahora las multinacionales están interesadas en productos editoriales guiados más con fines políticos y económicos y, por consiguiente, buscan crear públicos consumidores para sus productos, ${ }^{10}$ muchos de ellos orientados hacia un entretenimiento que no implique un trabajo intelectual consumidor de tiempo y esfuerzo; aunque quizás algo de su contenido pueda convertirse en el relleno de las representaciones sociales.

Hoy vemos que la producción de libros y revistas alcanzan cifras impresionantes de miles de volúmenes más que antes de Internet y, como decíamos anteriormente, más personas acceden al nivel básico de educación, por tanto, suponemos que se lee, sí pero mucha literatura de mala calidad.

\section{Los medios masivos de comunicación}

A lo anterior sumamos los medios masivos de comunicación que han adquirido un poder sobre la sociedad al grado de que no sólo informan; también crean opinión, modelan el lenguaje, la mente y las prácticas sociales. Imponen representaciones de la realidad, lenguajes, modas, necesidades. Satisfacciones ficticias, realidades que no existen más que en los noticieros. Los contenidos banalizados exhiben la vida privada, lo más íntimo del ser humano, todo lo convierten en espectáculo para entretener, ése es el requisito, eliminar cualquier esfuerzo mental y físico, y a ello hay que agregar otro ingrediente, la inmediatez. Esos contenidos son los modelos de los contenidos de la producción escrita, impresa o digital y tienen una poderosa circulación. Entre la vastísima oferta de radio, televisión, prensa e Internet, una proporción mínima está destinada a incluir ofertas culturales e informativas de calidad que inciden en el interés por la lectura.

10 Este fenómeno es abordado en los libros de: André Schiffrin. La edición sin editores. Barcelona: Destino, 2000. 151 p. 
Desde luego ante un contexto cultural como el presente la sociedad está expuesta a un vacío impuesto por la oferta del mercado, el cual ofrece placer puesto en los objetos, a los cuales les hemos delegado el poder de seducirnos e imponernos sus leyes; es decir, las del mercado. Nuestros referentes culturales librescos pueden aparecer como caducos, e incluso ser substituidos por aquellos que prometen hacer de nosotros los sujetos que exige el mundo moderno. En este vacío florece la representación de Internet, un medio cuyos significado y utilidad están ahí para ser apropiados por los ciudadanos junto con la socialización de valores, ideas, modelos, deseos, carencias.

\section{LA LECTURA AL SERVICIO DE INTERNET}

Decíamos en un inicio que los programas gubernamentales inducen a la idealización de Internet. Es decir, al pretender usar ésta para subsanar problemas sociales y económicos, incluso históricos, como el acceso a la educación o servicios de salud, entre otros, para todos los sectores de la población, esto podría permitirles a los desfavorecidos tener oportunidades de desarrollo; y de ser así entonces el poder de Internet podría pensarse como una tecnología que por sí misma tendría la capacidad de solucionar los problemas sociales, al igual que se piensa que con sólo alfabetizar a los ciudadanos éstos pueden ingresar a las oportunidades que brinda la cultura escrita. Encontramos que la representación social de Internet es institucionalizada y contextualizada mediante dos vías: una vertical, impuesta desde los altos mandos políticos, económicos, educativos, culturales y transferida para ser asumida por la sociedad. La otra horizontal, transmitida entre los individuos y asumida para ingresar en determinados grupos o bien para no ser excluidos del propio. Entonces podríamos preguntarnos si más allá de la preocupación por la lectura existe el interés de poner esta actividad al servicio de Internet. 
Así entonces, las características de la sociedad globalizada, denominada "Sociedad de la Información", 11 articulada por la infraestructura tecnológica, tendría en la información un recurso estratégico cada vez más visible en formas y medios digitales. Si bien, por ahora guardan similitud con los impresos, pero empiezan a adquirir peculiaridades propias que no pueden ser trasladas a las páginas impresas, como ya mencionamos, una de esas características es la interactividad. Al respecto algunos estudios revelan cambios en las conductas lectoras e informativas, en particular entre los medios académicos, por lo que cabe suponer el surgimiento de un nuevo público de lectores para quienes la computadora y el libro sean usados con la misma o mayor frecuencia. En un futuro el libro podría formar parte de los recursos complementarios en el ámbito universitario.

Para ilustrar lo anterior podemos observar en la página siguiente el cuadro del estudio que recientemente llevé a cabo sobre Los efectos de internet en las prácticas de lectura y en el acceso a la información de la comunidad académica y estudiantil. El modelo de la $U N A M,{ }^{12}$ el cual está integrado por estudiantes de primero y último semestres y por investigadores que, además, imparten docencia.

En los datos obtenidos identificamos una población emergente entre la que se destacan aspectos de accesibilidad, facilidad y rapidez para acceder a la información digital. Encontramos también la formación de prácticas de lectura en pantalla, que por el momento es de una hora. Además, un poco más de la mitad de la población encuestada lleva a cabo la denominada lectura interactiva.

11 Elsa M. Ramírez Leyva. La lectura en la sociedad contemporánea. En Investigación Bibliotecológica: archivología, bibliotecología e información ene./jun. 2001, vol. 15 , no. 30 , p. 116

12 Elsa M. Ramírez Leyva. Los efectos de internet en las prácticas de lectura y en el acceso a la información de la comunidad académica y estudiantil. El modelo de la UNAM. Madrid: El autor, 2003. Tesis de Doctorado, Universidad Complutense de Madrid. 


\begin{tabular}{|c|c|c|c|c|c|c|c|c|}
\hline ACTIVIDAD & $\%$ & $\%$ & EDAD & SEMESTRE & GÉNERO & GÉNERO & ÁREA & FACULTAD \\
\hline $\begin{array}{c}\text { Acceso sin restricciones } \\
\text { de horario }\end{array}$ & 20.59 & 74.84 & $35-45$ & Primero & Masculino & Ambos & Ciencias & Ciencias \\
\hline $\begin{array}{l}\text { Mayor rapidez en la } \\
\text { localización de } \\
\text { información. Internet vs. } \\
\text { medios impresos }\end{array}$ & 20.59 & 31.42 & $35-45$ & Primero & Masculino & Masculino & Ciencias & Ciencias \\
\hline $\begin{array}{c}\text { Facilidad de localizar } \\
\text { información Internet vs. } \\
\text { Biblioteca }\end{array}$ & 20.59 & 22.27 & $35-45$ & Primero & Masculino & Masculino & Ciencias & Ciencias \\
\hline $\begin{array}{c}\text { Fácil de usar internet vs. } \\
\text { Biblioteca }\end{array}$ & 20.59 & 24.63 & $35-45$ & Primero & Masculino & Masculino & Ciencias & Ciencias \\
\hline $\begin{array}{l}\text { Encuentra la información } \\
\text { que necesita en Internet }\end{array}$ & 5.88 & 14.60 & $35-45$ & Primero & Ambos & Masculino & Ciencias & Ciencias \\
\hline \multicolumn{9}{|l|}{ ACADÉMICOS } \\
\hline ESTUDIANTES & & & & & & & & \\
\hline
\end{tabular}

Por otra parte, aparentemente Internet no ha provocado una disminución significativa en el uso de los impresos y servicios bibliotecarios, sin embargo un $20 \%$ de los encuestados cree que los medios tradicionales de lectura e información serán sustituidos por los medios digitales e Internet. En cuanto al sector científico éste ya ha asimilado la lectura de revistas científicas directamente en la pantalla. Además, las obras de consulta e información están totalmente integradas en sus modos actuales de informarse.

La población de estudiantes de primer semestre de la carrera se inició en el uso de la computadora e Internet, en promedio, a los 16 años, pero la tendencia de uso de Internet se extiende ahora hasta la secundaria y la primaria. Las nuevas generaciones seguramente empezarán a dominar la textualidad digital y con ella nuevas prácticas de lectura.

\section{PARA TERMINAR}

Dado lo anterior es importante definir para qué formar lectores; qué modelo cultural es el que países como el nuestro necesita para construir la representación y las prácticas sociales de la lectura en esta sociedad contemporánea. Lo anterior nos obliga a renovar los fundamentos sobre los que se construyen los modelos institucionales 
destinados a formar prácticas sociales de lectura en diferentes modalidades y para distintas actividades y públicos lectores. Esas prácticas deben encarnarse en los recursos documentales y también en los servicios, los espacios y los programas de promoción de la lectura. En suma, integrarse al discurso bibliotecológico, pues finalmente participamos en el modelo cultural y por tanto es mejor asumirlo de manera consciente y como efecto de nuestras decisiones.

Encontramos que en las instituciones universitarias de países como México la práctica de leer en Internet no ha adquirido, todavía, las características de un cambio drástico, aunque este medio ya ha sido asimilado y es usado para fines académicos o de estudio. Sin embargo, es conveniente estar atentos a una situación que sin duda preocupa al sector educativo en algunos países desarrollados como en Estados Unidos. Al respecto Wallace, señala: “[...]por ejemplo, hace unos años los educadores animaban con entusiasmo a los estudiantes a entrar en la red para investigar; ahora, muchos están preocupados porque los estudiantes entregan trabajos en cuyas bibliografías sólo aparecen recursos de Internet y muchas de las fuentes que citan son cuestionables." 13 Y agrega algo muy importante: "las universidades que antes aconsejaban buscar información en la red sin matices están revisando a toda prisa sus currículos para fomentar el empleo del pensamiento crítico con el fin de evaluar debidamente toda esa información." 14 Llama la atención en la cita de la autora que la revisión sobre los planes de estudio no menciona la necesidad de crear habilidades para favorecer la lectura del material impreso y otros medios, es decir, la lectura múltiple.

Quizá en este momento todavía no percibamos el impacto de Internet en el modelo cultural libresco, pero no podemos negar la formación de grupos emergentes que obtienen en Internet el placer que han encontrado en los impresos, además de resolver sus necesidades y realizar los deseos que el mundo contemporáneo está creando.

13 Patricia Wallace. La psicología de Internet. Barcelona: Paidos, 2000. p. 56

14 Ibidem. 
Así, en el contexto actual, el sector bibliotecológico tendrá que diseñar estrategias para reconfigurar la representación social de la institución bibliotecaria, y por tanto las prácticas de lectura y de información de las comunidades. De no trabajar en este sentido, Internet ganará el terreno que no cultive el sector bibliotecario; por consiguiente es indispensable estudiar las prácticas de nuestros lectores a fin de buscar que la actividad bibliotecaria resignifique su función en estos tiempos de Internet y no sucumba debido al alejamiento de nuestros lectores.

\section{BIBLIOGRAFÍA}

CHARTIER, Anne-Marie Y Jean Hébrard. La lectura de un siglo a otro. Discursos sobre la lectura (1980-2000). Barcelona: Gedisa, 2002. 205 p.

ILLICH, Iván. En el viñedo de texto. Etología de la lectura: un comentario al "Didascalicon" de Hugo de San Victor. México: FCE, 2002. $210 \mathrm{p}$.

JITRIK, Noé. Lectura y cultura. $3^{\mathrm{a}}$ ed. México: UNAM, 1998. 120 p.

LAFUENTE López, Ramiro. En el umbral del cambio: las tecnologías de la información y la comunicación. México: UNAM, CUIB, 1997. 123 p. (Monografías; 22).

LLEDÓ, Emilio. El surco del tiempo. Meditaciones sobre el mito platónico de la escritura y el tiempo. $2^{\mathrm{a}}$ ed. Barcelona: Crítica, 1992. $231 \mathrm{p}$.

ORGANISATION FOR ECONOMIC COOPERATION AND DEVELOPMENT. Knowledge and skills for life. Firts results from PISA 2000. París: OECD, 2001. 322 p. 
RAMÍREZ Leyva, Elsa M. La lectura en la sociedad contemporánea. En Investigación Bibliotecológica: archivología, bibliotecología e información ene./jun. 2001, vol. 15, no. 30, pp. 114-131

--. Los efectos de internet en las prácticas de lectura y en el acceso a la información de la comunidad académica y estudiantil. El modelo de la UNAM. Madrid: El autor, 2003. Tesis de Doctorado, Universidad Complutense de Madrid.

Prácticas sociales y representaciones / ed. Jean-Claude Abric. México: Ambassade de France, Coyoacán, 2001. 226 p.

SCHIFFRIN, André. La edición sin editores. Barcelona: Destino, 2000. $151 \mathrm{p}$.

WALLACE, Patricia. La psicología de Internet. Barcelona: Paidós, 2001. 312 p. 


\title{
Pasado, presente y futuro de la lectura: algunos dilemas desde el punto de vista de un editor
}

\author{
DANIEL GOLDIN
}

1.

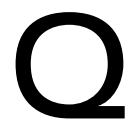

uiero agradecer a Elsa Ramírez su generosa invitación a platicar con ustedes. "Pasado, presente y futuro de la lectura" será el tema de las jornadas, me comentó Elsa cuando me llamó, hace unos meses, para invitarme. Me gustaría que tú hablaras del futuro del libro y la lectura desde el punto de vista de un editor."

No se trata ciertamente de un tema muy original y adivino en ustedes un cierto fastidio al imaginar mis palabras. De hecho, en México y América Latina desde hace algunos años y cada vez con mayor intensidad, la preocupación en torno al futuro del libro y la lectura parece haber monopolizado toda reflexión pública en torno a la cultura escrita. No hay reportaje, entrevista, documento o programa político en el que no se repita, con frecuencia sin sostén alguno, una queja ante la reducción de lectores, un anhelo de que haya cada vez más, una preocupación o temor acerca del fin del libro, condenado a desaparecer, primero ante el embate de la tv, después ante el advenimiento de la era de la comunicación electrónica.

Con singular alegría e irresponsabilidad y amparados en la vaguedad de términos como lector y lectura, los medios han contribuido a convertir una suma de opiniones y observaciones parciales, en verdades incuestionables que generan confusión, desaliento. Creo que México no es el único país en el que la opinión pública parece solazarse al marcar los bajos niveles de lectura de sus habitantes. 
Lo preocupante es que todas esas inquietudes no hayan motivado un avance decisivo en el conocimiento de la situación, que las decisiones políticas y económicas se realicen con base en esos supuestos. Que haya tan poco interés por disponer de datos más o menos ciertos y de investigar, al menos la validez de los presupuestos.

Lo preocupante es que al libro y la lectura se les sigue asociando sin ninguna distancia crítica a valores como desarrollo, bienestar y democracia. Lo preocupante es que no haya espacios para argumentar y discutir. Por esto mi agradecimiento al CUIB. Ojalá que un espacio así sirva para estimular la investigación y para discutir las ideas y preconcepciones.

Se me ha pedido que hable desde el punto de vista de un editor, así que trataré de responder a las interrogantes desde mi perspectiva profesional.

Los editores -que habitualmente acompañamos a los creadores que gozan del prestigio como tales- utilizamos nuestra facultad creativa para muchas cosas: para hacer libros, autores, mitos, campos de estudio o conversaciones, como diría Gabriel Zaid. Podríamos detenernos en cada uno de ellos, pero me parece que sería importante centrarme en otro tipo de creación. Me refiero a la creación de lectores.

Como lo habrán visto ustedes, el asunto parece ser de interés público. Enciende pasiones, encona ánimos, genera polémicas, por llamar de algún modo al griterío que tanto medios se encargaron de avivar. A juzgar por el lugar que ocupa en los programas políticos, la formación de lectores también parece ser una prioridad nacional, no sólo en el plano educativo y cultural, también en la política y en el desarrollo económico.

Aunque no es un asunto que siempre haya preocupado a los editores, me parece que hoy la formación de lectores es una cuestión que atañe a los editores de manera esencial y conflictiva. Esencialmente, porque detrás de la supuesta o real desaparición de lectores, los editores vemos la mayor amenaza a nuestro futuro. Y de manera conflictiva porque, a pesar de eso, los editores no tenemos claro que la formación de lectores sea una responsabilidad que debamos o podamos asumir. 
El problema es ciertamente muy complejo y no espero elucidarlo aquí. Pero podríamos tratar de plantearlo para esclarecer y facilitar la discusión. De entrada me parece imperioso alejarnos de una doble tentación.

Por una parte, de la tentación -nihilista y generalizadora- imperante en ciertos medios que consideran al libro y a los lectores como especies en peligro de extinción, lo cual alteraría toda una cadena ecológica de la cual los editores somos un eslabón. Debido a esto hay que hallar pronto una pócima mágica que remedie esta situación, o cambiar de oficio.

Pero también debemos alejarnos del optimismo ingenuo, sustentado en experiencias exitosas más o menos heroicas, a partir de las cuales se pretende establecer criterios de validez general.

A la primera tentación, fatalista y oscura, es preciso oponerle la idea de que el futuro será, como el presente, menos uniforme que los discursos acerca de él. Por eso es importante socavar ese inmovilizante discurso desde sus raíces: a partir de cuestionar críticamente conceptos y categorías en apariencia claros y unívocos, usados con una peligrosa liberalidad por periodistas, autoridades e incluso por editores. Libros, lectura, librería, biblioteca, leer, escribir, editar. Cada uno de los sustantivos y verbos relacionados con el mundo de la producción y circulación de la palabra escrita tienen sentidos múltiples, que coexisten en cada momento histórico, y que -como hoy todos sabemos- han variado notablemente a lo largo de la historia.

El término lector, por ejemplo, sirve para designar lo mismo a un estudiante que año con año subraya manuales para pasar exámenes, que a alguien que devora novelas policiales en sus horas de transporte, o a quien fatiga un libro rumiando cada uno de sus renglones. $\mathrm{O}$, para decirlo en términos que seguramente le interesan más a los directores comerciales de las empresas editoriales, bajo el término lector englobamos a un chico que compra libros prescritos y los lee por obligación (y que seguramente no volverá a ellos tras abandonar la escuela), a un ama de casa o un obrero que compra y lee libros para ocupar un tiempo muerto (pero que muy probablemente deje ese pasatiempo cuando se modifiquen las circunstancias) y a alguien que 
ha hecho de la lectura una forma de vida (aunque rara vez compre novedades en las librerías).

A la segunda tentación, que, en las antípodas del fatalismo mira el futuro con un optimismo alegre es necesario oponerle la comprensión de la lectura y la escritura en un conjunto de prácticas sociales complejas. Esta gran corriente, de larga duración, impone ciertos condicionantes; ofrece posibilidades de desarrollo y limita otras. Y, vale la pena recordarlo, nos permite comprender que no todo lo que tiene que ver con la producción y circulación de lo escrito recae sobre los profesionales de esas prácticas.

\section{2.}

Para centrar la discusión, resumo algunas premisas básicas de mi postura:

La primera es que aunque sólo una pequeña minoría de editores desarrollamos esfuerzos directamente relacionados con la animación a la lectura, los editores siempre formamos lectores. Al elegir tal o cual tema o autor; al establecer colecciones, formatos o portadas; al fijar precios; al proponer o establecer canales de promoción y comercialización, los editores abrimos o cerramos oportunidades para que personas "no lectoras" se conviertan en lectoras y también modificamos o afianzamos formas de ser lector. Es decir, para seguir valiéndonos de la metáfora arquitectónica que utilizó nuestro presidente en el programa "Construir un país de lectores", en cada uno de los pasos de la gestión editorial los editores construimos, remodelamos o demolemos lectores.

La segunda es que la relación entre editores y lectores no es una relación unívoca. También los lectores modifican o posibilitan formas de ser editor. Al elegir o rechazar autores u obras, al optar por determinada forma de acceder a los libros (la compra, el robo, el préstamo), al aceptar o rechazar las pautas de recepción que éstos les proponen. 
Por último cabe decir que, aun cuando unos y otros nos construimos mutuamente a través de una compleja interrelación, no estamos solos en una isla. También los autores, bibliotecarios, ingenieros, transportistas y maestros, legisladores y publicistas, ministros de hacienda y de cultura, abren o cierran posibilidades para que se formen lectores y editores. Y para que se redefinan sus funciones.

Este doble conflicto (entre dos libertades que al elegir o rechazar, al aceptar o modificar posibilitan o clausuran formas de ser lector o editor, que a su vez están condicionados por otros factores internos y externos al ámbito de la producción y circulación de la palabra escrita) dificulta en grado extremo plantear de una manera simple el interés común entre unos y otros. Sobre todo cuando queremos abordar el problema de manera procesal, en ciclos más o menos largos.

Definido lo anterior conviene que nos detengamos a analizar las nuevas condiciones y modalidades de la relación entre editor y lector. Y aquí me parece necesario cuestionar críticamente dos aseveraciones comúnmente aceptadas. La primera es que hoy hay menos lectores que antes. La segunda es que la transformación en las pautas de organización de la industria editorial ha sido consecuencia -y no causa- de las transformaciones en la conducta lectora.

3.

¿Es cierto que cada vez hay menos lectores? ¿Se debe esto al auge del internet, al desarrollo de los medios masivos, al deterioro de la educación? No es posible afirmar esto. La pretendida reducción de lectores por el auge de los medios es una afirmación muy discutible (y poco discutida), incluso en términos meramente estadísticos. Y conviene recordar que en México no tenemos ni siquiera una encuesta nacional de lectura, que sería el instrumento ideal para juzgar, como sucede en muchos países europeos, la evolución de las conductas lectoras en términos cuantitativos, que, desde mi punto de vista es un tipo de aproximación que genera una enorme confusión amparada en la supuesta asepsia de las cifras. Para decirlo brevemente, leer 5, 10 o 30 libros al año, no tiene valor en sí. Hay formas de 
consumo o frecuentación de los libros en las que la lectura jamás incrementa la capitalización cultural del lector y por tanto su capacidad para participar activamente en la determinación de su vida. Por tanto, multiplicar la cifra de libros leídos por año no forzosamente conllevaría una alteración en la relación que el lector establece con su propia vida y su entorno a través de la palabra escrita. Y es justamente esta dimensión cualitativa el único sentido que puede tener la formación de una sociedad lectora, al menos en términos educativos, políticos y culturales (aunque a los editores probablemente les podría interesar simplemente aumentar el consumo de libros).

Y si valoramos la conducta lectora en términos cuantitativos, la evidencia que se nos presenta es, por el contrario, que en la actualidad hay el mayor número y diversidad de usos y usuarios de la cultura escrita al amparo del más amplio espectro de discursos legitimadores jamás habido. Lo vemos todos los días, no en las bibliotecas o en las librerías; en los mercados, en los pueblos donde no hay una sola biblioteca y ahora se han instalado estaciones de internet a través de las cuales la gente investiga, se comunica, participa o consume. Y esto afecta necesariamente el estatus de la palabra escrita, como lo ha afectado, en los recintos universitarios la cada vez mayor producción de conocimiento o, para ser más exacto, información.

Tradicionalmente la lectura y la escritura han sido ejercicio de unos cuantos, no de todos; de élites políticas, económicas y/o religiosas más o menos extendidas. Sólo hasta hace pocos siglos la lectura pasó de ser el privilegio de unos cuantos, a ser "obligación" de todos, un asunto de ciudadanía, como ha dicho Emilia Ferreiro. La multiplicación de usos y usuarios derivada de la educación obligatoria, la proliferación de saberes a ella asociada, el cuestionamiento y la creación de pautas y cánones de lectura han tenido un papel fundamental para cambiar el paradigma desde el cual el libro y la lectura hacían patente su valor singular en el conjunto de prácticas sociales.

Es fascinante ver cómo coinciden factores técnicos, culturales, políticos y económicos diversos en el trastrocamiento de ese paradigma. Por ejemplo, la conservación del orden y la preservación de la memoria, dos funciones comúnmente asociadas a la escritura desde su milenaria invención, han perdido preponderancia: hoy sabemos 
que gran parte si no es que la totalidad de lo que ahora se publica desaparecerá antes de cincuenta años, pues el aumento del alfabetismo y el incremento de la necesidad de leer han provocado la búsqueda y, en consecuencia, la invención de nuevas materias escriptorias, del papel reciclado a la pantalla electrónica, como ha señalado Armando Petrucci. ${ }^{1}$

Este paleógrafo italiano ha observado también cómo, aún antes del vertiginoso auge del internet, se han mermado las posibilidades de una coincidencia efectiva entre las expectativas de autores o editores y sus lectores. Aparentemente se han liberado controles antes impuestos:

En el pasado no sólo la lectura sino sobre todo la escritura, como práctica y como expresión potencialmente subversiva, fue sometida a fuertes controles y a rígidas censuras. Hoy en el ámbito de aquella que hemos definido como "escritura privada", se rechaza cualquier tipo de restricción, de comportamiento obligado, de canon y de regla. La escritura "anárquica" como la lectura salvaje, se convierte en una práctica puramente individual, dictada únicamente por el placer personal y por la voluntad de divertirse y de expresarse libremente. ${ }^{2}$

Sin duda, es posible contemplar esto como un avance democrático, pero no sólo ni necesariamente es esto. Tal vez lo que asoma es la anomia, quizá a lo que estamos asistiendo es a un nuevo alejamiento de la palabra, del diálogo como instrumento de autorregulación. Y esto es algo que debe o debería ser de la mayor importancia para los editores, los bibliotecarios, los promotores; pero no sólo para los profesionales de la cultura escrita. Se trata de un asunto que afecta la parte más íntima y profunda de la construcción de una comunidad y de la constitución de la subjetividad y por tanto nos concierne a todos.

1 Armando V. Petrucci. Alfabetismo, escritura, sociedad. Prol de R. Chartier y J. Hébrard, Gedisa, Barcelona 1999, Col. LeA.

2 El propio Petrucci aborda esto en el último capitulo de la Historia de la lectura en el mundo occidental bajo la dirección de Guglielmo Cavallo y Roger Chartier, Taurus, Madrid, 1998. 
4.

Sin duda es cierto que los editores (podría decir lo mismo para cualquiera de los otros gremios de la cultura escrita) hemos debido cambiar para adaptarnos a nuevas condiciones del mundo globalizado. Pero también hemos sido actores de ese cambio, y si no queremos caer en un fatalismo inmovilizante, debemos comprender que un nuevo escenario hace que las antiguas respuestas pierdan vigencia, presenta problemas, pero no impone una vía única para resolverlos.

Por eso me parece importante que revisemos las transformaciones que ha habido en cada una de las etapas de la producción y circulación de lo escrito y ver de qué manera han contribuido a hacer de la producción y circulación de los libros (independientemente de su calidad) un elemento potenciador de la masificación de la cultura.

Al comparar las transformaciones de nuestro gremio con las que han ocurrido en otros sectores es fácil percibir pautas comunes. Como todos los otros profesionales, los editores hemos tenido que aprender a ponderar nuestro trabajo en términos de eficiencia y eficacia, a racionalizar gastos, planear objetivos y a replantear nuestro oficio y nuestro negocio. Siempre nos habíamos considerado especiales, por eso el desconcierto no ha sido poco. Tal vez por eso hemos asumido los retos y desafíos de este nuevo escenario con menos creatividad y profundidad que la que debían caracterizar al gremio que durante siglos tuvo encomendada la salvaguarda de las ideas y creaciones del hombre. Desde luego con una pobre conciencia de gremio.

Durante siglos la producción y circulación de los libros fue, antes que nada, cosa de oficio: con un léxico propio y, sobre todo, con una forma de reclutamiento y formación de profesionales. Cualquiera que haya sido el puesto, el saber decisivo provenía de su propia especificidad: la producción y o circulación de la palabra escrita.

En la actualidad la mayor parte de las ventas se da fuera del ámbito restringido de las librerías, casi todos los conocimientos tradicionales han perdido validez o se resignifican desde saberes nuevos. Hoy, en el gremio, el saber decisivo y por tanto el poder decisorio no proviene del ámbito del oficio. Hace algunos años a la cabeza de los grandes grupos estaba un editor, hoy un financiero. En la vieja polémica entre 
los números y las letras, los editores nos sentíamos naturalmente inclinados hacia las letras. Hoy en el sector conviven publicistas, técnicos en computación, correctores, financistas y comerciales y los números son la única linguae franca en el interior de la empresa. La gestión se mide en la lógica fría, contundente y concisa de un balance de resultados. Y desde esa fría lógica "cada grado e instrumento intermedio que pueda permitir una relación diversa de aquella de la compraconsumo es evitada o anulada". ${ }^{3}$ Es un gasto superfluo o, si se quiere, una inversión a largo plazo altamente riesgosa y de redituabilidad difícilmente comprobable. Formar un lector, recordémoslo, es crear un posible cliente para la competencia.

Es natural que en un escenario así el lector sea más extraño que nunca.

Parte de la casi histérica preocupación por los lectores que prospera en el medio se debe a la paradoja de que se nos haga patente que los necesitamos, pero que la lectura en cuanto tal no aparezca en ningún indicador de nuestra gestión. ¿Y en él los indicadores que usan los bibliotecarios para evaluar su gestión si aparece?

El lector es un objetivo, un target, como dicen algunos colegas anhelando tener la misma precisión que los misiles teledirigidos. ${ }^{4} \mathrm{El}$ lector siempre ha sido un desconocido para el editor (no para el bibliotecario, no para todos al menos). Pero antes se podía suponer una probable identificación con él. Como los autores, los editores podíamos aseverar con cierta soltura que publicábamos tal o cual obra porque es era la clase de libro que querríamos leer. Y es que había condiciones para sostener la apuesta. Hoy es difícil sostenerla

$3 \quad$ Ibid p. 264.

4 ¿Cómo podemos construir lectores y hacerlo cuando la implacable lógica en la que se ha internado la producción y circulación de lo escrito lo primero que le pide a un editor es asegurar la apuesta, cuando obras que hace menos de 50 años tardaron más de 10 años en agotar su modesta primera edición de 2000 ejemplares, hoy se publican en ediciones de centenares de miles de ejemplares que se venderán en supermercados y puestos de periódicos y meses más tarde en baratillo o trituradoras de papel? 
pues las modificaciones en la economía del libro hacen insostenible una apuesta a largo plazo.

Lo más paradójico es que, a medida que se reducen los espacios y oportunidades para establecer con el público una relación distinta a la compra-consumo, el peso del público es más importante en la definición de la apuesta editorial. Por ellos hay tantos editores subordinados a los directores de marketing que presumen conocer al público de una manera objetiva. Por eso en las ferias del libro vemos cómo se reduce y homogeneiza la oferta y observamos estantes llenos de réplicas de apuestas supuestamente seguras, que terminarán en la guillotina.

Tal vez ha llegado el momento en que debamos preguntarnos si lo que está en juego es sólo nuestra sobrevivencia. Si lo que realmente debería importarnos no es el pasado presente y futuro del libro, sino las posibilidades que tienen o pueden tener las personas en la definición de su futuro, en la reconstrucción de su pasado y de habitar el presente. Por esas posibilidades muchos de los aquí presentes nos hemos acercado al libro y la lectura.

5.

A muchos editores nos gusta pensar en la importancia que tiene nuestra profesión para el bien común y declarar, por ejemplo, que sólo una sociedad con libertad de edición puede ser democrática. Por eso buscamos concitar el apoyo social y pugnamos por dispensas fiscales, compras aseguradas u otros mecanismos para garantizar nuestra sobrevivencia que, no hace falta recordarlo, para el resto de la sociedad rara vez tiene la misma trascendencia.

Por eso también nos sumamos con evidente simpatía al inusitado consenso social a favor de la construcción de lectores. Por paradójico que parezca, tal vez el resultado de foros como éste debería ser otro: contribuir a desmontar ese aparente consenso, evidenciar sus debilidades, hacer patente en último caso su inoperancia para establecer los criterios y jerarquizaciones necesarios para instrumentar estrategias o políticas concretas. 
"Construir lectores" es una consigna hueca que pueden pronunciar los políticos sin mayores consecuencias, pero no los editores, pues, si bien es cierto que el futuro de las editoriales depende de la existencia de lectores, no es menos verdad que del tipo de lectores que haya (o más bien posibilitemos que existan, ya que a lo único que podemos aspirar es a posibilitar que otros se construyan a sí mismos como lectores) dependerá la modalidad de futuro que le espera a la industria editorial.

Hace falta aclarar los qué y los para qué, no sólo los cómo. Hace falta precisar qué lectores buscamos y, sobre todo, qué estamos dispuestos a hacer en cada uno de los procesos de nuestra gestión para conseguirlo: ahora que todo se rige por el mercado, hace falta que aclaremos cuánto valen para nosotros los lectores y cuánto estamos dispuestos a invertir para construirlos.

Hay lectores que, no obstante comprar y leer libros, socavan las posibilidades de futuro para la industria editorial en el largo plazo. Hay apoyos que, si bien en lo inmediato resuelven los apremiantes problemas de los editores, en realidad minan su futuro.

En un momento en que es indispensable aceptar la realidad del mercado, debemos preguntarnos si la mejor forma de participar en él es adherirnos a una lógica económica empeñada en producir hombres prescindibles.

En un contexto económico y político caracterizado por la imposición de caminos únicos, debemos reflexionar si lo que garantizará nuestra viabilidad no será diferenciarnos, mostrar y posibilitar otros caminos. En un momento en que paradójicamente los hombres estamos cada vez más comunicados y más aislados, los editores debemos preguntarnos de qué diablos hablamos cuando hablamos de formar lectores. No es sólo una cuestión de principios, se trata de un asunto de racionalidad empresarial: debemos saber cuál es nuestro capital y dónde conviene invertir para potenciarlo.

En resumen, me parece que en un momento en que técnicamente es más fácil que nunca ser editor, los profesionales de la producción y circulación de la palabra escrita debemos replantear nuestra función social. Sin duda hay muchas respuestas. Doy la mía: me parece que la tarea que el editor no puede dejar es justamente mediar: entre autores 
y lectores, entre necesidades presentes y futuras, entre diversas culturas y campos del saber, entre la tradición y la novedad. Esto supone antes que nada abogar por un espacio para la palabra, para el diálogo. Creo que podremos ser valiosos socialmente y nos será legítimo demandar condiciones que garanticen nuestra supervivencia, en la medida en que seamos garantes de que exista una arena pública en donde se discutan razonadamente los intereses públicos y que esto le permita a los hombres autorregularse.

Por eso me parece imperioso que la industria editorial se autorregule en un marco de acciones concertadas entre todos los profesionales relacionados con la producción y circulación de lo escrito. Y no puede haber mejor regulador que una población de lectores autónomos, con la capacidad para ejercer esa autonomía con responsabilidad.

¿Cómo comenzar? La mayor parte de los programas o discursos parten del supuesto que hay que privilegiar diversos grupos, edades o ámbitos. Por ejemplo, la casa y los niños pequeños. Conozco y he apoyado proyectos que rompen éste y otros moldes, y me parece peligroso suponer, también aquí, un camino único.

¿Por dónde comenzar entonces? Cómo dice Eliot: "En mi principio está mi fin”. En los principios. En los fines. En los principios que no se pueden violar. En los fines que debemos tener presentes en cada momento de la gestión y en la totalidad de la cadena: si lo importante es el lector, en cada eslabón se debe evidenciar una hospitalidad esencial hacia él, una hospitalidad que permita que exista siempre ese otro, en tanto otro, construyéndose otro como lector. La calidad del papel, el interlineado, el cuidado editorial, revelan la presencia o ausencia de esa hospitalidad. Pero también el espacio que le demos en el estand, la estrategias para promocionar o comercializar los libros.

Y es aquí donde la investigación sociológica y antropológica nos aporta un material mucho más rico que cualquier discurso mercadotécnico para comprender lo que debemos hacer para posibilitar la formación de más y mejores lectores. Detrás de cada lector hay personas, presencias y ausencias que los libros suplen o recuerdan. Personas, cuerpos, gestos, modulaciones de voz, palabras e imágenes. Personas en contacto con otras personas. 
¿Por qué entonces el sector ha asumido tan alegremente hacer eficiente su gestión reduciendo posibilidades de esos encuentros? ¿Por qué gastar dinero en carteles y anuncios televisivos y no en la formación de promotores culturales? ¿Por qué las inversiones públicas se centran en las bibliotecas, no en los bibliotecarios? ¿Por qué, en suma, se evita invertir en personas o en propiciar espacios para encuentros entre personas?

La relación con los libros no empieza con la lectura y los libros no sólo sirven para leer. Son objetos cargados de valores afectivos, son objetos que huelen, que pesan, que tienen texturas, que se asocian a voces y personas, que generan situaciones y las recuerdan. Pero también se leen y adquieren valor al suscitar apropiaciones. Es eso lo que le da el valor a los ojos del público. En la economía del libro no hay una relación directa entre compras y capacidad económica. El precio que la gente está dispuesta a pagar por ellos depende del valor que le den a la lectura y a los libros en su vida. Y esto no es algo que se pueda imponer. Por más efectivas que sean las campañas publicitarias y comerciales. Lo saben los propios comerciales y publicistas.

$\mathrm{Si}$, como tanto insistimos los editores, los libros son objetos singulares (culturales y mercancías, bienes de capital y de consumo), no podemos seguir las pautas de organización que dictan los manuales del empresario moderno. No, al menos, en todos los procesos.

Creo que esto es algo que se puede aplicar también a los bibliotecarios. El peligro que corremos en este afán por adecuarnos a una racionalidad empresarial es que abaratemos nuestro capital. El peligro que corremos en esta agitada búsqueda de lectores es que olvidemos lo más elemental y que contribuyamos al oscurecimiento de la palabra. Aunque éste se dé en un caótico bullicio de discursos a favor de la lectura. 


\title{
Investigación de la lectura en Alemania. Métodos y resultados
}

\author{
Christine GARBE
}

SOBRE LA HISTORIA Y LA SITUACIÓN ACTUAL DE LA INVESTIGACIÓN SOBRE LA LECTURA EN ALEMANIA

Wa primera parte de mi ponencia doy una visión general de los
planteamientos teóricos y los métodos empíricos de la investiga-
ión sobre la lectura en Alemania. En la segunda parte profundizaré en la discusión que se lleva a cabo actualmente en Alemania respecto a la lectura, la cual fue motivada por los resultados del estudio internacional PISA 2000; y en la tercera parte presento resultados acerca de la investigación biográfica de la lectura y con base en ellos muestro algunas posibilidades para fomentar exitosamente la lectura.

El paradigma de la socialización en la investigación de la lectura

Los últimos tres decenios han sido un periodo fértil para la investigación de la lectura y los medios de comunicación en Alemania. En los años setenta, el paradigma de socialización se integró en la investigación de la lectura y sustituyó los conceptos más antiguos del "desarrollo a través de la lectura" y la "educación a través de la lectura", por el concepto de la socialización a través de la lectura o la socialización literaria. La idea de un desarrollo a través de la lectura supone un proceso de maduración interno casi "natural"; en Alemania se hablaba de diferentes "etapas de edad de lectura", que se basaban una en otra, y que recibieron sus nombres según el supuesto material de lectura preferido en cada una: la "edad de los cuentos de hadas", la "edad de Struwwelpeter (Pedro el Hirsuto), la "edad de las baladas", 
la "edad de Robinson", etcétera. Este desarrollo parecía transcurrir de manera ampliamente automática, y por tanto escaparse de una influencia intencional por parte de los padres y los maestros. En cambio, el concepto de la "educación a través de la lectura" o la "educación literaria" se refería a todas las formas de intervención intencional en este desarrollo, estaba dirigida por las normas específicas de una "formación literaria", y ahora sobreestimaba con mucho, a la inversa, las posibilidades de una influencia consciente sobre los procesos invaluados en el desarrollo literario. Frente a esto el concepto de la "socialización a través de la lectura" abrió el campo de la investigación para planteamientos nuevos y de mayores alcances.

Este concepto de socialización debe su origen a la teoría de la socialización, que en los años 70 y 80 se convirtió en el paradigma directivo en las ciencias sociales y de la educación en Alemania (Hurrelmann / Ulich 1991).

Esta corriente de la investigación intenta abarcar todas las influencias intencionales y las condiciones no intencionales a través de las cuales un ser humano recién nacido se convierte en un "sujeto capaz de actuar en sociedad"; es decir, se capacita para convertirse en miembro de un orden social existente (Hurrelmann en Groeben 1999b; Hurrelmann 2002).

En los años 70, y parcialmente en los años 80, estas influencias eran modeladas de manera más bien determinista: la sociedad marca al individuo, o el individuo tiene que adaptarse a la sociedad. En cambio, desde mediados de los años 80 se ha colocado en el primer plano una visión social-constructivista: el individuo se apropia activamente de las normativas de la sociedad, él construye su propia biografía en una sociedad abierta. La sociología alemana acunó una serie de conceptos para describir las sociedades del conocimiento post-industriales, post-modernas: "sociedad del riesgo" (Beck 1986), "sociedad de opción múltiple" o "sociedad de la vivencia" (Schulze 1992), se cuentan entre los conceptos más conocidos.

De manera paralela a la investigación de la socialización en las ciencias sociales, también la estética de la recepción en la ciencia literaria descubrió al lector como un sujeto que actúa activamente, que en el acto de la lectura construye un significado subjetivo diferente 
en cada caso a partir de la "partitura" del texto. Mencionemos a los dos más importantes representantes de la llamada Escuela de Constanza de la estética de la recepción en Alemania: Wolfgang Iser (1972; 1984; 1991) y Hans Robert Jauß (1982).

Esta visión fue fortalecida sobre todo por la investigación de la lectura de la psicología cognitiva, sobre todo de los países anglosajones: la lectura no es una recolección pasiva de sentido, sino una construcción activa de dicho sentido. En este proceso, el lector debe recurrir a sus propios conocimientos del mundo, sus experiencias vitales y sus experiencias literarias.

En estas dos fuentes se apoya la investigación de la socialización a través de la lectura, y -en sentido más estricto- la investigación de la socialización literaria. Sus cuestionamientos principales son los siguientes:

¿Cómo se convierte un niño, un joven, o un adulto, en un lector asiduo (babitual) (de literatura)? ¿Qué factores -influencias personales, instancias e instituciones de la educación para la lectura, qué oferta de lecturas y medios de comunicación- son especialmente importantes para una "carrera de lector" que tenga éxito? Aquí, el tema esencial es el de "socialización para la literatura”. Los más importantes intentos de sistematización, de los años 90 en Alemania, los presentaron Hartmut Eggert y Christine Garbe, con su introducción "Socialización Literaria" (1995), y Cornelia Rosebrock, con un volumen antológico sobre la "Lectura en la época de los medios de comunicación" (1995).

La perspectiva general de la investigación que presentamos Hartmut Eggert y yo se ha convertido entretanto en una obra estándar en la investigación alemana sobre la lectura, a la cual se hace referencia en muchos tratados; esta obra contiene una visión general de la historia de la investigación sobre la lectura, los conceptos teóricos de diferentes disciplinas (ciencia literaria, lingüística, psicología, sociología, pedagogía, etcétera), los diferentes métodos empíricos y los más importantes resultados de la investigación empírica en la zona de habla alemana. Por ello, me da un gusto especial poderles traer como regalo la segunda edición, actualizada, de nuestro libro, que acaba de aparecer hace dos semanas. 
Sobre este campo se presentan importantes investigaciones empíricas en los dos tomos de la obra Socialización a través de la lectura (1993), financiados por la fundación Bertelsmann: Volumen 1: "Clima de lectura en la familia”, por Bettina Hurrelmann y otros, y Volumen 2: "Lectura en la vida diaria de los jóvenes", de Heinz Bonfadelli y Angela Fritz, y "Carreras de lectores - continuidad y rupturas", de Renate Köcher.

El segundo planteamiento de la investigación sobre la socialización a través de la lectura es el siguiente: ¿Qué consecuencias tiene la lectura (de literatura) sobre el proceso de socialización (o desarrollo de la personalidad)? ¿Qué funciones y significados subjetivos tiene la lectura para la capacidad de acción social y la formación de la identidad personal de un sujeto en la sociedad actual de los medios de comunicación, del saber, o de la información? Aquí el concepto esencial es "socialización a través de la literatura". Esta cuestión trató ya de dilucidarla Helmut Fend en 1979 en su estudio del mismo nombre, referido a las clases escolares de literatura; sin embargo, el problema también subyace a muchos estudios cualitativos de los años 80 y 90 , sobre todo en el ámbito de la investigación biográfica de la lectura, sobre lo cual hablaré más adelante en detalle. Con respecto a la especial importancia de la lectura en la infancia y juventud, hay que mencionar aquí sobre todo las investigaciones y estudios de casos de Werner Graf $(1995 ; 1997 a ; 1997 b ; 2001)$ y Erich Schön $(1989 ; 1990 ; 1993)$, que se encuentran en numerosos artículos dispersos; el proyecto de investigación de Kassel "Historia de la lectura como apropiación de la cultura”, de los años 80, de Rudolf Messner, Cornelia Rosebrock y otros (los resultados están publicados en Behnken y otros 1997), o como el más reciente ejemplo, el estudio de Hartmut Eggert, Christine Garbe, y otros, sobre la "Intelectualidad literaria en la sociedad de medios de comunicación" (Eggert y otros 2000), en el cual hemos evaluado entrevistas de amplio alcance con 24 estudiantes.

Resumiendo: el horizonte de cuestionamientos de la investigación de la socialización a través de la lectura y la literatura es mucho más amplio que el de una enseñanza tradicional de la lectura o una didáctica de la literatura: sobre todo se trata de condiciones personales, estructurales e institucionales, que desempeñan un papel en el proceso 
de un desarrollo hacia el lector y, en consecuencia, tanto de influencias intencionales de los padres, de la escuela, de las bibliotecas y de otras instancias de fomento a la lectura, como también de efectos no intencionales, o incluso efectos no deseados, de la clase escolar de literatura, de los entornos mediales, o del clima familiar de lectura.

El tema de investigación "Socialización a través de la lectura en la sociedad de medios de comunicación"

Con el paradigma de la socialización literaria se ha trazado el contorno de un complejo campo de investigación que requiere una combinación de diferentes disciplinas especializadas y métodos. Desde principios de los años 90 existen en Alemania esfuerzos, impulsados inicialmente por mi maestro, el profesor Hartmut Eggert, de la Universidad Libre, de Berlín, por reunir los proyectos de investigación y a los investigadores e investigadoras que hasta ese momento estaban trabajando de forma aislada. A mediados de los años 90 surgió de esto -tras varios simposios preparatorios- una solicitud a la Sociedad Alemana de Investigación para establecer un tema de investigación sobre "Socialización a través de la lectura en la sociedad de medios de comunicación", el cual fue aprobado en 1997, y desde 1998 les da apoyo a entre doce y quince proyectos de investigación (cada uno con duración de dos años) (Groeben [Ed.] 1999a).

Este tema de investigación busca lograr un intercambio entre diferentes disciplinas científicas y culturas especializadas, así como una integración de métodos cuantitativos y cualitativos. Los investigadores e investigadoras participantes provienen de la ciencia y la docencia literarias, de la investigación sobre literatura infantil y juvenil, de la ciencia de la comunicación y los medios, de la psicología, sociología y pedagogía, así como de la psicología pedagógica. El espectro de los métodos que representan abarca desde los tests psicológicos estrictamente estandarizados, pasando por sondeos estandarizados y parcialmente estandarizados a través de cuestionarios, hasta la observación participante (basada en la investigación de campo etnográfica), el análisis documental de los productos de los alumnos, y entrevistas abiertas, narrativas. Los cuestionamientos del tema de investigación 
se extienden a tres dimensiones de análisis: para mostrarlo, les he reunido algunos ejemplos de cada dimensión en una lámina:

1. Socialización a través de la lectura bajo una perspectiva diacrónico-histórica (del sistema social en su conjunto); es decir, proyectos sobre la historia de la socialización a través de la lectura de los siglos XVIII hasta el XX;

2. Socialización a través de la lectura bajo una perspectiva diacrónico-individual; es decir, proyectos sobre el desarrollo en la historia de la vida de "carreras de lectores", respecto a biografías de lectores, e instancias centrales de socialización a través de la lectura, como la familia, la escuela, los grupos de personas de la misma edad, etcétera.

3. Socialización a través de la lectura bajo la perspectiva sincrónicosistemática; es decir, proyectos sobre la lectura y la utilización de medios, la competencia de lectura y la de utilización de medios, en los niveles que alcanzan actualmente algunos grupos objetivo.

Del programa temático de la Sociedad Alemana de Investigación que estará en vigor todavía hasta el año 2004, han surgido hasta el momento las siguientes publicaciones conjuntas:

1. El folleto especial número $10 \mathrm{del}$ IASL, Archivo Internacional de Historia Social de la Literatura Alemana (1999), en el cual se presenta el programa temático y todos los proyectos individuales;

2. Un número especial de la revista SPIEL (2000), en el cual se presenta el espectro de métodos dentro del campo temático;

3. Un número de la revista "Estudios Psicológicos de Colonia", en el cual se presentan explicaciones conceptuales centrales del campo temático; y dos publicaciones, en las cuales se presentan los primeros resultados de los proyectos individuales:

4. Norbert Groeben / Bettina Hurrelmann (Ed.): Competencia de lectura. Condiciones, Dimensiones, Funciones, Weinheim y Munich 2002.

5. Ídem (Ed.): Competencia medial. Condiciones necesarias, Dimensiones, Funciones, Weinheim y Munich 2002. 
Finalmente, quiero señalar que existen también muchas otras investigaciones respecto a la lectura por fuera del campo temático de la Sociedad Alemana de Investigación, por ejemplo las apoyadas por la Fundación de la Lectura, de Maguncia. Señalemos dos importantes publicaciones de los años más recientes:

- En 1999 apareció el "Manual de Lectura" (por encargo de la Fundación de la Lectura y la Conferencia Alemana de Literatura), una reelaboración totalmente nueva del primer "Manual de Lectura", de 1974, y como aquél, de casi 700 páginas.

- En el año 2001 apareció el estudio "Conducta respecto a la lectura en Alemania en el nuevo milenio", de la Fundación de la Lectura y la Editorial Spiegel, financiado, entre otros, por el Ministerio Federal de Educación e Investigación, en el cual se llevaron a cabo 2,530 entrevistas estandarizadas y 120 entrevistas con hilo conductor, con una muestra representativa de Alemania en su conjunto para cada caso. Con este estudio se obtiene una buena visión general sobre la investigación cuantitativa y cualitativa sobre la lectura en Alemania, y sobre los más recientes datos acerca de la conducta de los alemanes referente a la lectura.

LECTURA EN ALEMANIA - RESULTADOS ACTUALES DE LA INVESTIGACIÓN Y CAMPOS PROBLEMÁTICOS

\section{El Shock del Estudio PISA y sus consecuencias}

En diciembre de 2001, cuando los resultados del Estudio PISA Internacional 2000 fueron publicados en Alemania, ésta recibió un shock que desató una amplia discusión sobre la política educativa. El Estudio PISA, en el cual se verificaron las llamadas competencias básicas en alumnos de quince años de ambos sexos en un total de 32 Estados -en el punto esencial de la competencia de lectura, pero también en la competencia matemática y la competencia científica- reveló toda la verdad: en todos los ámbitos verificados, pero especialmente en el ámbito de la competencia de lectura (reading literacy), los estudiantes alemanes están en la tercera parte inferior de entre 
los 31 Estados participantes. En la "Escala general de lectura", Alemania ocupó el lugar 21, y muestra con ello (si prescindimos de Liechtenstein: lugar 22, y Luxemburgo: lugar 29) ipeores resultados que todos los demás países de Europa occidental y central, y los países anglosajones!

En el estudio mencionado, México ocupa el penúltimo lugar (30), por arriba solamente de Brasil. Ignoro cómo fue recibido este resultado en México, pero en Alemania, el país tradicional de los "poetas y pensadores", de Goethe y Schiller, de Kant y Hegel, este resultado desencadenó un verdadero "shock" nacional. Desde entonces, los problemas de la lectura, de la competencia para la lectura, y del fomento de la lectura, reciben de nuevo una gran atención pública.

Dado que no sé con qué intensidad ha sido discutido en México el estudio PISA, quiero presentar primero algunos resultados de dicho estudio referido a Alemania; después, explicaré lo que se entendía por "competencia de lectura" en el estudio, y sobre qué elementos los resultados nos aportan información. Finalmente, quiero presentar la crítica que han hecho al concepto de la competencia de lectura de PISA algunas investigadoras e investigadores alemanes, en la medida en que estén involucrados con el concepto de la socialización a través de la lectura. Esta crítica apunta sobre todo a afirmar que PISA no capta las causas de una carencia de competencia de lectura de manera adecuada, y que tampoco pueden sacarse del estudio PISA conclusiones prácticas para un fomento de la lectura prometedor y que pueda tener éxito.

Los resultados de este primer examen internacional de rendimientos PISA 2000 (Programme for International Student Assessment) desataron en Alemania un fuerte debate sobre política educativa: en el ámbito de la competencia de lectura, casi $\mathbf{1 0} \%$ de la población de alumnos examinados (niños de 15 años al final del periodo escolar obligatorio) no alcanzaron ni siquiera el más bajo de cinco niveles de competencia, cuyas exigencias están definidas de la siguiente forma: captar las ideas principales, localizar información sencilla, y vincular el texto y el conocimiento cotidiano. Otro 13\% de los estudiantes alemanes estaban en el nivel I de competencia, es decir, no eran capaces de realizar rendimientos sobre compresión de textos 
que fueran más allá de ese nivel, como clasificar y evaluar las informaciones leídas. Por lo tanto, según el examen PISA, casi una cuarta parte de los alumnos alemanes solamente estaban dotados al final de su periodo escolar obligatorio con capacidades mínimas de lectura, uno de cada 10 jóvenes estaba incluso por debajo de este mínimo, y podría formar parte en potencia del creciente número de los llamados analfabetas funcionales o secundarios de las sociedades post-industriales. La Sociedad Alemana de Analfabetismo (en su investigación número $\mathbf{x x x}$ ) parte de que en Alemania (de cerca de 80 millones de habitantes), unos 4 millones, es decir 5 por ciento, son analfabetas, y que las escuelas alemanas canalizan a la sociedad cada año a unos 80,000 jóvenes que están en camino hacia el "analfabetismo secundario": ien realidad un resultado verdaderamente demoledor respecto al sistema escolar alemán!

Los expertos del Estudio PISA definen a "los niños de 15 años que no han alcanzado el nivel de competencia I, como grupo de riesgo con respecto a sus perspectivas de tener éxito profesional" (PISA $2000,117)$. La proporción de los niños de inmigrantes en este grupo de riesgo es especialmente alta, o sea que su integración a la comunidad lingüística alemana muestra considerables déficits, porque el dominio del alemán como idioma de uso cotidiano es una condición esencial para la competencia de lectura en el examen alemán de PISA. Pero la carencia de las capacidades lingüísticas de ninguna manera puede limitarse solamente a este grupo social de los niños con trasfondo de migración; también niños alemanes con asombrosas debilidades en su idioma materno recibían evidentemente menos apoyo compensador en el sistema educativo alemán que en otros países. Por ello, de los 31 Estados que participaron en este examen de rendimientos escolares, Alemania solamente ocupó el lugar número 21 en la escala general. El alto porcentaje, de casi una cuarta parte, de quienes estaban en el nivel de competencia I y por debajo, contribuyó, esencial pero no exclusivamente, a este resultado; también en el nivel de competencia más alto, el V, la participación de los estudiantes alemanes estuvo por debajo del promedio internacional (PISA 2000, 103). También llama la atención que la distancia entre los alumnos más débiles y los más fuertes en rendimientos en Alemania es mayor 
que en todos los demás países, y que la escuela en Alemania demuestra ser especialmente incapaz de nivelar las condiciones culturales debidas al medio ambiente: en Alemania existe la relación más grande entre el origen social y el éxito en la educación. Dicho de otra manera: quien viene de una casa paterna bien situada social y culturalmente tiene las mayores oportunidades para hacer una exitosa carrera escolar, y en cambio aquéllos que estén en desventaja respecto a su "capital cultural" por su origen familiar, son quienes tienen oportunidades especialmente malas para nivelar estas desventajas en el curso de su socialización escolar.

Las diferencias entre los sexos, por lo que toca a su conducta y su competencia respecto a la lectura, conocidas desde hace mucho en la investigación de la misma, fueron también confirmadas por el estudio PISA: las niñas no solamente leen de otra manera y otras cosas que los niños, sino que también leen mejor: concretamente, con una distancia significativa, en todos los 31 Estados examinados (imientras que las diferencias en los rendimientos matemáticos fueron significativas en favor de los niños solamente en 14 Estados, y las de los rendimientos de ciencias naturales solamente en 3 Estados!): "Las mayores y más consistentes diferencias de sexo se observan en el ámbito de la lectura. En todos los Estados participantes en el estudio PISA, las niñas obtuvieron en la lectura notas significativamente más altas que los niños. En Alemania, la ventaja en rendimiento corresponde aproximadamente a la mitad de un nivel de competencia, y es comparable en términos generales con la diferencia detectada en todos los Estados de la OCDE." (PISA 2000, p. 253).

$\mathrm{Al}$ respecto es notable, sobre todo, que la distancia entre niños y niñas se hace tanto más grande cuanto más exigentes sean las tareas (y alcanza su mayor nivel en las tareas del ámbito "reflexionar y evaluar", Cf. ídem, p. 254). Esto se muestra especialmente en los llamados "textos continuos", esto es, en los textos escritos puros, mientras que las diferencias entre las niñas y los niños son menores en los llamados "textos no continuos", es decir, combinaciones de letras e imágenes. También en la velocidad de lectura, las niñas son claramente superiores a los niños. 
Precisamente en el examen de las diferencias entre sexos, para los expertos de PISA se reveló una relación claramente demostrable entre el interés por la lectura y el rendimiento de lectura: "En la mayor parte de los Estados participantes en el estudio, la actitud de los niños respecto a la lectura es claramente más negativa que la de las niñas. En el promedio de los países de la OCDE un total de aproximadamente 46 por ciento de los niños contestaron afirmativamente la pregunta de si solamente leen cuando tienen que hacerlo, mientras que solamente 26 por ciento de las niñas afirmaron esto de sí mismas. En Alemania, la proporción de las niñas es comparable con el valor internacional (también 26\%), pero la proporción de los niños es claramente superior (52\%)." (PISA 2000, 262).

Correspondiendo a estas actitudes sobre la lectura, los niños y niñas de quince años se distinguen también claramente con respecto al tiempo que leen todos los días. En Alemania, 55\% de los niños indican que nunca en absoluto leen por gusto (valor medio de la OCDE: $40 \%)$, mientras que la proporción correspondiente para las niñas es de $29 \%$ (valor medio de la OCDE: $23 \%$ ).

El promedio de ambos sexos que nunca lee por gusto es entre los jóvenes de Alemania de $42 \%$, y con ello ocupa de nuevo el primer lugar entre todos los países en los cuales pudo demostrarse una relación estadística significativa entre la lectura durante el tiempo libre y la capacidad de lectura (ien casi la mitad de los Estados examinados!) (PISA 2000, p. 114).

El concepto de competencia de lectura en el Estudio PISA

Para ocuparse del estudio PISA 2000 es primero indispensable aclarar qué es lo que se entiende aquí por "competencia de lectura" ("Reading Literacy"), y por lo tanto, qué fue lo que se examinó. El concepto de lectura en el que está basada la concepción internacional del Estudio PISA no se alimenta de teorías de la ciencia literaria o hermenéuticas, sino de enfoques de psicología cognitiva de la investigación de la comprensión de textos, y tiene una fuerte orientación pragmática o funcionalista: "La competencia de lectura se entiende en el Estudio PISA, de acuerdo con la investigación de la comprensión de textos, 
(...) como un trabajo activo con los textos. En la literatura psicológica sobre la comprensión de textos existe unanimidad acerca del hecho de que el proceso de comprensión del texto tiene que entenderse como una actividad de construcción por parte del individuo. Leer no es una recepción pasiva de la información que está contenida en el texto correspondiente, sino una (re)construcción activa del sentido del texto. Las afirmaciones contenidas en el texto se vinculan activamente con el conocimiento previo, el conocimiento del mundo y el conocimiento lingüístico que posee el lector. El trabajo con el texto se puede entender como un acto de generación de sentido, en el cual interactúan el conocimiento previo del lector y la tarea objetiva del texto" (PISA 2000, p. 70/71). En este contexto, son conceptos centrales por ejemplo la noción del "buen procesador de información" (p. 76), la "capacidad para leer de forma estratégica, referida a las tareas y los objetivos" (p. 73), la "competencia metacognitiva” (p. 77), un "amplio repertorio de estrategias específicas y generales", así como una "rica base de conocimientos" (ídem).

La lectura se entiende sobre todo como "lectura de información", o como "medio para construir estructuras de saber", y por lo tanto, como calificación clave en la sociedad de información o de saber, basada en las letras. La "competencia de lectura" (Reading Literacy) significa comprender textos escritos, aprovecharlos y reflexionar sobre ellos, con el fin de alcanzar objetivos propios, desarrollar más el propio saber, y participar en la vida social." (p. 80).

Siguiendo el enfoque pragmático y psicológico-cognitivo, la competencia de lectura se subdivide en tres competencias parciales, dos de las cuales se basan en que se aprovechen primordialmente informaciones internas al texto ("obtener informaciones", "interpretación referida al texto"), y la tercera exige la asociación de estas informaciones con el conocimiento externo al texto ("reflexionar y evaluar") (Cf. PISA 2000, 82 ss.). Por lo tanto, las tareas del ámbito "reflexionar y evaluar" son las más exigentes; ellas presuponen la obtención de informaciones y la interpretación referida al texto, y exigen que el lector relacione el texto "con experiencias propias, inventarios de conocimientos e ideas" (PISA 2000, 83). 
El corpus de textos que fueron utilizados en el estudio PISA para las pruebas de lectura se basa, de acuerdo con el enfoque pragmático, en un concepto muy amplio de texto: además de los llamados textos "continuos" (es decir, escritos de manera continua), también se incluyeron combinaciones de textos e imágenes o diagramas, planos, tablas o gráficas (los llamados textos "no continuos"), en total con una proporción de 62 : 38 por ciento. (Cf. PISA 2000, p. 81, Tabla 2.1). El examen internacional de lectura abarcó 141 tareas, referidas a un total de 37 diferentes textos. De éstos, muy pocos son textos narrativos o literarios en sentido estricto: de los textos continuos, $12 \%$ se asignan a la categoría "cuento", el resto se refiere a textos apelativos o expositivos. También las tareas formuladas respecto a los textos, que se reconocen por las tareas documentadas como ejemplo, se refieren casi exclusivamente a capacidades cognitivas de comprensión de textos: no se examinan de manera explícita ni capacidades emocionales o estéticas, ni morales, sociales o reflexivo-críticas de las normas.

Lectura como práctica cultural / Competencia de lectura en el contexto de socialización

El concepto funcionalista y predominantemente cognitivo del estudio PISA ha sido problematizado explícitamente por investigadores de la lectura, pedagogos y docentes; de la forma más amplia por la profesora Bettina Hurrelmann, de la Universidad de Colonia, que vincula sus deducciones del estudio PISA con un "alegato en favor de un concepto didáctico de la lectura como práctica cultural" (Hurrelmann 2002a). Ella señala que, sobre todo en una perspectiva didáctica, es indispensable introducir un concepto de lectura de mayor amplitud que comprenda las motivaciones para la lectura, los sentimientos durante la lectura, y las conversaciones sobre lo leído; es decir las dimensiones motivacionales, emocionales e interactivas, como componentes ellas mismas de la competencia de lectura, y no como "variables de fondo", como sucede en el estudio PISA. Esto es de importancia central sobre todo en la perspectiva de socialización, y por lo tanto también para la didáctica, pues describe la diferencia entre el acto de la lectura y la socialización a través de la misma: "entre la 
medición del logro y la introducción en el mundo del idioma escrito" (Hurrelmann 2002a, 7).

Si no se quieren sacar conclusiones abreviadas problemáticas de los malos resultados que obtuvieron los alumnos de Alemania en el examen internacional PISA (como por ejemplo: "necesitamos más entrenamiento en estrategias de lectura en las escuelas!”), entonces se tiene que incluir en la consideración el proceso mismo de la socialización a través de la lectura en el modelado de la competencia de lectura. Por lo tanto, el tema de investigación interdisciplinario "Socialización a través de la lectura en la sociedad de medios de comunicación" que he presentado anteriormente ha desarrollado otro modelo de "competencia de lectura en el contexto de la socialización", que parte de la idea directiva normativa de un "sujeto capaz de actuar socialmente" ( $C f$. Hurrelmann 2002c, 111-126). Este modelo incluye las condiciones personales, sociales y mediales de una socialización exitosa a través de la lectura, al igual que los efectos sociales y personales de una competencia de lectura desarrollada. Las dimensiones descriptivas de la competencia de lectura abarcan motivaciones, cogniciones, emociones, reflexiones, y finalmente todas las interacciones referidas a la lectura, casi siempre resumidas en los últimos tiempos con el término de "comunicaciones de contacto" (Groeben/Hurrelmann,Medienkompetenz 2002', pp. 11-18 y 275-286).

El estudio de PISA mismo señala indirectamente la necesidad de un modelo ampliado de este tipo cuando constata que existe una relación significativa entre el interés por la lectura y la competencia de lectura (Cf. PISA 2000, 129). Esto resulta especialmente claro en las ya mencionadas diferencias en la competencia de lectura específicas de los sexos. Mediante análisis de regresión ha podido demostrarse que el interés en la lectura tiene un alto valor explicativo para la capacidad de lectura. En otras palabras: al comparar las capacidades lectoras de los niños y niñas que muestran un interés igualmente grande por la lectura, se reducen muy considerablemente las diferencias; si se agregan todavía diferentes indicadores para el gusto por la lectura, desaparece casi por completo la influencia del sexo en la capacidad de lectura. "Por lo tanto, si existe un gusto comparable por la lectura, no son de esperarse diferencias significativas en la capacidad de los niños y las niñas. 
Estos resultados señalan que las diferencias de los sexos en el ámbito de la lectura están motivadas, por lo menos en parte, por diferencias en las características motivacionales." (PISA, p. 265). Las autoras de este capítulo del estudio PISA llegan a la conclusión de que un "fomento de la lectura para los jóvenes" tendría que comenzar "especialmente en la motivación para la lectura y en las actividades vinculadas con ella" (ídem, 266).

Por lo tanto, también desde la misma perspectiva del estudio PISA, se señala la cuestión de las condiciones personales, sociales y mediales de una exitosa socialización a través de la lectura y un fomento de la misma, pregunta a la cual el enfoque del estudio de PISA no es capaz de dar respuesta. Por ello, la socialización a través de la lectura tiene que ser modelada a partir de la perspectiva de la adquisición (Rosebrock 2002), si se quieren llevar a cabo intervenciones exitosas en dirección a un fomento sistemático y sistémico de la lectura. Con ello llego a la tercera parte de mi ponencia: algunos resultados de la investigación biográfica de la lectura, en la cual también deben incluirse mis propias investigaciones (especialmente respecto a las diferencias de sexo en la socialización literaria).

\section{RESULTADOS DE LA INVESTIGACIÓN BIOGRÁFICA DE LA LECTURA}

La investigación biográfica de la lectura se interesa sobre todo por la cuestión de la adquisición de hábitos, intereses y competencias de lectura; por lo tanto, inquiere las condiciones bajo las cuales un infante, un niño que todavía no habla, se convierte en un lector adulto.

\section{"La lectura es la actividad menos natural del cerebro"}

La dificultad de esta cuestión se pone de manifiesto si nos damos cuenta de un hecho que ha formulado de la siguiente manera el investigador alemán del cerebro, el fisiólogo y psicólogo, profesor Ernst Pöppel (de la Universidad de Munich): "La lectura es la actividad más antinatural del cerebro. "La lectura de letras, afirma Pöppel, 
no había sido prevista por la evolución. Uno de los más enormes desarrollos mentales del ser humano ha sido el de formular el lenguaje en la escritura. El cerebro utiliza para las actividades de la lectura y escritura una parte que en realidad tiene otras tareas, y tiene que aprender en un trabajoso proceso los gigantescos logros de abstracción que se requieren para transformar todo aquello que es posible decir en un sistema de solamente 25 a 30 letras. [Por lo demás, el cerebro solamente es capaz de aprender a leer en los primeros diez años de vida de forma que se domine sin esfuerzo.] (Pöppel 2002, p. 747).

A diferencia de lo que sucedía hace pocos decenios, gracias a los progresos en la investigación del cerebro, la psicolingüística y la psicología cognitiva, actualmente conocemos con mucho más detalle las exigencias extraordinariamente complejas que están vinculadas con el proceso de la adquisición del lenguaje escrito en las escrituras alfabéticas, es decir, con el aprendizaje de la lectura y la escritura.

En el ámbito de las cogniciones se trata de procesos de identificación de palabras y frases, de la asociación de grupos de frases, de la elaboración global de coherencia, la asignación a macroestructuras (tipos de textos), y finalmente, del conocimiento de las intenciones de los textos y los medios de representación; en el ámbito de las motivaciones y emociones, se trata de la capacidad de comprometerse afectivamente en la lectura (disfrute, identificación, etcétera), de la capacidad de construir una disposición a la lectura (motivación de lectura) y de la capacidad de ajustar unas a otras las necesidades y las ofertas de lectura; en el ámbito de las reflexiones, finalmente, se trata de actividades reflexivas durante la lectura (p. ej., estrategias de verificación metacognitivas), y de la capacidad de realizar intercambios comunicativos respecto a lo que se ha leído, tras haber realizado la lectura.

Para la investigación biográfica de la lectura, de esto se deriva la cuestión siguiente: ¿en dónde depende el proceso de adquisición de competencia de lectura de manera especialmente intensa de contextos sociales que lo apoyen? En otras palabras: precisamente porque la lectura es para el cerebro una "actividad antinatural", la constitución de motivaciones para la lectura y la adquisición de la competencia de lectura depende de manera mucho más intensa del apoyo 
personal por parte de adultos competentes que cualquier otra forma de utilización de medios de comunicación: en cuanto sea capaz de hablar, uno puede sentar a un niño solo frente a una grabadora de cassettes o un televisor, y un poco más tarde, frente a un gameboy, una consola de juegos o la pantalla de una PC; ipero no frente a un libro! El oído y la vista, las formas de percepción que se requieren para aprovechar los medios auditivos o audiovisuales, se adquieren en una etapa mucho más temprana de la vida que las capacidades de la lectura y la escritura. Por ello, la investigación biográfica de la lectura, que reconstruye a partir de los testimonios escritos u orales de lectoras y lectores adultos cómo es que han llegado a ser lectores, ha formulado como su primer y más importante hallazgo que:

La lectura no es una "actividad solitaria", al contrario: la formación de una praxis de lectura estable a lo largo de las etapas de la vida depende de contextos de apoyo sociales y comunicativos; es decir, de relaciones personales. En la infancia, este contexto está representado sobre todo por la familia, casi siempre en la figura de la madre; en la pubertad y adolescencia, este papel lo cumplen, por un lado las personas de la misma edad (amigos, grupos de referencia, culturas juveniles y sus medios de comunicación), y por el otro también personas de referencia adultas que cumplen una función de modelo o de orientación; aquí, muchas veces le corresponde un importante papel a la personalidad de algunos lectores y lectoras ( $C f$. Schön 1993; Garbe/ Groß, en Garbe [Ed.] 1993).

La "iniciación literaria primaria"

Hasta ahora, la investigación biográfica de la lectura ha obtenido su material sobre todo de círculos de adultos lectores jóvenes con un alto nivel escolar, o sea que ha investigado socializaciones más o menos "afortunadas" a través de la lectura. A partir de este material, intenta reconstruir fases típicas y formas de transcurrir de la socialización literaria. Especialmente interesante para la cuestión de las posibilidades y límites de las intervenciones prácticas (en el sentido del fomento a la lectura) es la cuestión de la relación que existe entre los factores de 
influencia externa y el desarrollo interno, es decir, de la socialización propia y la inducida.

De acuerdo con Werner Graf, Erich Schön y otros, en el desarrollo hacia el lector o lectora existen dos fases especialmente "críticas", en las cuales la formación de motivaciones estables para leer depende de contextos de apoyo externos: Werner Graf las llama "iniciación literaria primaria y secundaria". La introducción primaria en el mundo de los libros se lleva a cabo normalmente en la infancia temprana, es decir antes de su entrada a la escuela, concretamente escuchando narraciones o lecturas en voz alta por parte de la madre, el padre o los abuelos, y capacita al niño para experimentar como algo satisfactorio la inmersión en mundos ficcionales transmitidos oralmente. La praxis, experimentada como algo placentero, de la lectura en voz alta, o la lectura conjunta de libros de imágenes, está asociada a una situación comunicativa íntima, por ejemplo, como ritual de buenas noches antes de dormir en una tibia cama, de modo que las experiencias de lectura y las experiencias corporales experimentan aquí un entrelazamiento. También es importante el hecho de que en esta decisiva fase temprana del desarrollo de la lectura, la adquisición de la competencia de lectura (como construcción de una motivación estable para leer) se lleve a cabo sobre todo con textos de ficción, dado que los libros de información casi no son de interés para los niños de esta edad. Por lo tanto, si definimos la competencia de lectura con base en el resultado final deseado, como una competencia fundamentalmente pragmática para acceder a los textos de información objetiva, como lo hace el Estudio PISA, soslayaremos muy fácilmente el valor central de los textos de ficción, literarios en el proceso de la adquisición de esta importante competencia.

Así pues, en la fase preescolar de la "iniciación literaria primaria", el centro de estimulación radica en la familia, y por ello es difícil de alcanzar a través de medidas de fomento público a la lectura; resulta especialmente difícil compensar la falta de esta socialización literaria primaria en familias de las clases sociales más bajas, y de niveles culturales más bajos, mediante otras instancias de socialización a través de la lectura. Sin embargo aquí radica un sector esencial de tareas para los jardines de niños y las escuelas primarias; precisamente la 
escuela ya no puede limitarse actualmente a enseñar a los niños a leer y escribir, sino que, al mismo tiempo y desde el primer año, debe proporcionar un amplio acceso al mundo de los libros. Todos los resultados obtenidos en la investigación biográfica de la lectura nos sugieren considerar los primeros cuatro a seis años de escuela como la fase decisiva para fomentar escolarmente la lectura; es decir, el periodo comprendido entre los seis y los diez o doce primeros años de vida de los niños.

Los malos resultados respecto a la competencia de lectura de los jóvenes de quince años que ha revelado el Estudio PISA están fundamentados aquí, al inicio del periodo escolar.

Debido en gran parte a los desarrollos de los medios, actualmente tenemos que ver mucho más que antes con una situación en la cual los niños llegan a la escuela ya con marcadas competencias de recepción literaria o narrativa: a través de las lecturas que han escuchado en su casa paterna, los cassettes con radioteatros, las películas en la televisión o los videos que han visto; están familiarizados con historias, personajes y esquemas argumentales complejos. Pero para el proceso de adquisición del lenguaje escrito, en la escuela tienen que "volver a empezar de cero"; en los libros de texto usuales, se ven confrontados con las más simples palabras, frases e historias, lo cual no genera en ellos motivación alguna para seguir leyendo. Muchas veces, los niños viven en la escuela la experiencia "de que el desciframiento de la escritura es tan laborioso y toma tanto tiempo, que no puede satisfacer sus capacidades literarias de comprensión con los pequeños textos que leen ellos mismos. Durante mucho tiempo tienen que invertir tanta energía en los procesos cognitivos que para los lectores habituados ya ni siquiera penetran en la conciencia, que casi no es posible que hagan una construcción y metapercepción diferenciada de relaciones contextuales de lo leído, en completa oposición a lo que sucede con la recepción visual o auditiva de historias." (C. Rosebrock 2002, p. 13 MS). Por ello, una de las tareas decisivas, no solamente de la enseñanza de la lengua materna, sino de todas la materias que enseña la escuela primaria, consiste en organizar el proceso de aprendizaje de la lectura y la escritura, de manera que durante la adquisición de la competencia de lectura ino se pierda la 
motivación para leer! Para ello se requiere mucha habilidad didáctica, un alto nivel de competencia profesional y, primordialmente, una conciencia adecuada del problema por parte de los docentes; precisamente ésta última todavía brilla por su ausencia de manera muy notable, por lo menos en Alemania.

Una investigación actual en Alemania sobre el desarrollo de la motivación de lectura entre los niños de escuelas primarias (cuestionamiento de 1,200 niños del $2^{\circ}$ al $4^{\circ}$ año en Erfurt/Turingia, llevada a cabo también simultáneamente con sus padres y maestras de alemán) dio como resultado que una primera "caída de la lectura" comienza ya desde poco después del segundo año, o sea en la transferencia de la llamada "clase de iniciación" hacia la "lectura y escritura adelantada".

Un importante indicador de esto es el "gusto por la clase de alemán”. Si todavía en el segundo año $65.6 \%$ de las niñas y $51.7 \%$ de los niños contestan que la clase de alemán les gusta mucho, en el cuarto año ya solamente son $40.5 \%$ de las niñas y $28.6 \%$ de los niños. Por lo tanto, entre los jóvenes el gusto por la clase de alemán se redujo en estos dos años escolares casi en la mitad, y en las niñas en imás de un tercio! En otras palabras: menos de una tercera parte de los niños dicen al final de su etapa escolar primaria que les gusta la clase de alemán, en la cual como sabemos ise trata esencialmente de leer y escribir! Éste es un resultado dramático, ya que revela que en más de $70 \%$ de los niños y también en el $60 \%$ de las niñas, el proceso de adquisición del lenguaje escrito ha dejado considerables "heridas" que casi no se curan a largo plazo: los pobres resultados de los niños y niñas de 15 años en el Estudio PISA respecto a su capacidad y motivación de lectura ipodrían en buena parte tener aquí sus causas! De la investigación biográfica sobre lectura y medios podríamos adicionar aquí un resultado: si en la socialización literaria temprana preescolar y en los primeros años de escuela no se logra que los alumnos experimenten en la lectura como una práctica placentera y enriquecedora de la apropiación del mundo a través de los medios de comunicación, iy esto se está logrando de manera especialmente mala con los niños! entonces estos niños emigrarán en buena parte ya desde la época de su escuela primaria hacia otros medios, en especial los jóvenes hacia un uso casi exclusivo de 
medios con monitores: gameboy, consola de juegos, y PC. Numerosos resultados de estudios actuales sobre los medios de comunicación nos muestran que en las niñas se da más un uso complementario de "antiguos" medios impresos y "nuevos" medios audiovisuales y digitales, pero en los niños se está llevando a cabo cada vez más una sustitución de los medios impresos por los medios de monitor (Cf. Garbe 2003). Uno de los más grandes retos para la escuela primaria y secundaria del futuro consiste por lo tanto, en mi opinión, en un fomento de la lectura diferenciado por géneros, que tenga en la mira especialmente a los jóvenes como grupo problemático. Ellos son como grupo el principal objetivo del mercado comercial de los videojuegos; y sin una enérgica compensación por parte de las instancias pedagógicas; es decir, la casa paterna y la escuela, no podremos excluir a este respecto una profunda "decadencia medial" en el futuro. ( $C f$. Christian Pfeiffer: El desastre llega con destellos multicolores. En: Die Zeit, N. ${ }^{\circ}$ $39,18 / 9 / 2003$, p. 12). Por lo tanto, debe tratarse de lograr, sobre todo entre los jóvenes, constituir a largo plazo una motivación para la lectura, una competencia para la lectura, y hábitos de lectura.

¿Cómo continúa el desarrollo literario si esta "iniciación literaria primaria" originada en la casa paterna y la escuela primaria se ha llevado a cabo de manera exitosa? En las personas que después serán lectores asiduos, la adquisición de habilidades suficientes de lectura en los primeros dos a tres años de escuela desemboca en una fase de placentera lectura infantil, que sirve sobre todo para la obtención de disfrute y satisfacción de la fantasía, y que frecuentemente se puede satisfacer con materiales y géneros de literatura infantil trivial. Esta fase comienza entre los 8 ó 9 años, y llega más o menos hasta los 12; es decir, hasta el fin de la infancia, la escuela primaria y la etapa de orientación (fin del $6^{\circ}$ ). Aunque los materiales de lectura que prefieren los niños y las niñas son diferentes, el modo de lectura en la infancia es, en su mayor parte igual; o sea, todavía no individualizado: los niños se sumergen intensamente en los mundos ficcionales y se olvidan de todo lo que les rodea. Esta fase de un extenso "vicio por la lectura" la encontramos actualmente sobre todo entre las niñas de hogares que gustan de los libros o que proporcionan una estimulación cultural en términos generales, mientras que los niños muchas veces se vuelcan, 
ya en esta etapa de su vida, hacia el gameboy, los videojuegos o los juegos de computadora, practicando así otras formas de recepción de medios orientados hacia el placer. En esta fase del desarrollo de placenteras lecturas infantiles, los lectores o las lectoras infantiles son ampliamente autónomos, es decir no dependen de medidas pedagógicas tomadas por los padres o los maestros. Una vez que ha funcionado el "arranque inicial", se trata sobre todo de proveerles "material de lectura": y para ello es especialmente importante -además de los libros que se les regalan-que hayan conocido las bibliotecas o "autobuses de lectura" como proveedores de material de lectura sin costo, y hayan aprendido a aprovecharlos.

\section{La "iniciación literaria secundaria"}

Típicamente, la fase del vicio infantil por la lectura desemboca al fin de la infancia en una "crisis de lectura": por un lado, con el inicio de la pubertad, se ponen en primer plano otros intereses (el interés por el otro género, la moda o la apariencia exterior, las fiestas y discotecas, los encuentros con los amigos, la música, etcétera), y por el otro, justamente en el caso de los niños o niñas que leen mucho, su modo de lectura llega a un límite: los materiales recibidos con gran placer pierden su atractivo, y muchas veces ellos se dan cuenta de lo esquemático y serial de la forma en que se producen. Ahora, la "tarea del desarrollo" para continuar desarrollando la lectura consiste en una transformación del modo de lectura que hasta el momento se había dado, de manera que sea posible seguir manteniendo el placer de la lectura incluso en condiciones psíquicas diferentes y con competencias literarias más desarrolladas.

Por ello, la "crisis de la lectura" al final de la infancia desemboca ya sea en una interrupción del desarrollo de lectura que se ha dado hasta el momento (p. ej., dirigiéndose hacia otros medios), como resultado de lo cual se da la persona que no lee o que lee poco, o en una transformación de la forma de lectura que se tenía hasta ese momento, la cual puede tener diferentes resultados: por un lado, la limitación de la lectura a libros de información y especializados, o bien revistas y periódicos, y una interrupción de la lectura de ficción (el tipo 
de lectura, casi siempre masculino, del "lector de libros de información y especializados"); y por otro lado diferentes modalidades de lectura de literatura de parte de los adultos, la cual casi siempre se encuentra entre lectoras mujeres. En diferentes artículos de los años 90, Graf ha reconstruido sobre todo tres modalidades de lectura literaria (de ficción) entre lectores y lectoras jóvenes y adultos; éstos resultan de una combinación, en cada caso diferente, de los dos componentes placer por la lectura/motivación para leer, y competencia de lectura/competencia de recepción literaria. Para el llamado "lector conceptual", es característico que al desarrollar más ampliamente la competencia de lectura se pierda el placer por ésta; de los cual se culpa frecuentemente a la clase de literatura de la escuela. Pero al mismo tiempo se adoptan determinados "conceptos" normativos de la escuela o de otras instancias de formación, se internalizan y se estructuran hasta constituir con ellos un "superyó" literario propio, que ahora dirige la conducta de lectura posterior desde adentro. El "lector conceptual" se propone leer ya solamente libros "de alto nivel", o literatura que se ocupe de problemas, o los "clásicos", etcétera. En el otro extremo está el "lector de sentimiento", que sigue estando orientado por el placer, en cierto modo dirigido por su "ello", demuestra ser más bien resistente a los esfuerzos de formación escolar de la clase de literatura, y limita sus lecturas al espectro de la literatura de entretenimiento trivial, sencilla o poco ambiciosa. Sin embargo, la forma de lectura identificatoria, que casi siempre es algo que se ha conservado de etapas anteriores, logra tener tan poco acceso a la literatura clásica de alto nivel como a la literatura de la modernidad. Por lo tanto es característica del lector de sentimiento una continuación del placer infantil de la lectura, con un estancamiento de la competencia de lectura. El tercer tipo, el del "lector estético" (en cierta forma dirigido por su "yo") representa en la tipología de Graf el tipo ideal del lector adulto de literatura, dado que éste logra transformar ambas cosas: el placer infantil por la lectura se transforma en un placer sublimado más intensamente estético, lo cual solamente resulta posible a través de un perfeccionamiento de la competencia de recepción literaria. Las estrategias de lectura de la infancia, principalmente identificatorias, son sustituidas por formas de recepción más 
distanciadas pero de un mayor involucramiento interno. El proceso de lectura se modifica ahora en un juego recíproco de identificación y distanciamiento; se hace contradictorio en sí mismo, estimula intelectualmente y despierta necesidades de discusión. En este contexto, Graf habla de una pubertad literaria, en la cual el tipo de lectura infantil pasa por una crisis productiva, y se transforma en una conducta de lectura adulta ( $C f$. Graf 1995, p. 121)

Para este proceso de re-orientación en la adolescencia, a diferencia de las fases de lectura intrínsecamente motivada, y en parte en forma de vicio, del final de la infancia y la pubertad, son decisivos los centros de estimulación externos, los contextos externos de apoyo para la "iniciación literaria secundaria”. Según todo lo que sabemos, esta fase ofrece una gran variedad de posibilidades para un fomento extra-familiar de la lectura, especialmente a través de la escuela, que hasta el momento han sido aprovechadas sólo de manera insuficiente. Por la investigación biográfica de la lectura sabemos que precisamente en esta fase (al final del nivel secundario I y en el nivel secundario II, es decir, en los años 9/10 hasta el 13 del sistema educativo alemán) ${ }^{1}$ la persona del maestro de alemán muchas veces hace sugerencias decisivas, y por lo tanto proporciona accesos al espectro de la "alta literatura" tradicional y moderna, los cuales no hubiera sido capaz de obtener el joven lector por sí mismo. Parece ser especialmente decisivo para el peso de esta influencia de los maestros el hecho de que ellos mismos tengan una intensa relación con la literatura, y puedan transmitirla de manera creíble a sus alumnos y alumnas.

Las encuestas realizadas entre adultos jóvenes (en su mayoría estudiantes), cuya socialización a través de la lectura puede ser considerada exitosa en la medida en que se han convertido en lectores y lectoras, conducen por lo regular a los siguientes resultados: la clase de literatura (especialmente en el nivel superior del bachillerato) se

1 Nuestras nomenclaturas educativas son distintas pero aquí parece estar hablando Christine Garbe de lo que sería equivalente al primer año de nuestra preparatoria (nota del corrector). 
recuerda como positiva y llena de sugerencias, cuando ha logrado proporcionar el acceso a difíciles textos literarios a través de conversaciones llevadas a cabo entre el profesor y los alumnos, y, todavía mejor, cuando ha abierto el acceso para conversaciones en las cuales se interpretaba el sentido de las obras. La condición para estas "conversaciones literarias" es la persona del docente, en quien se percibe el entusiasmo por la causa que él representa ("La Literatura"), y cuya competencia literaria supera a la de los alumnos, pero que no reclama para sí el monopolio de la "única" interpretación correcta de un texto.

La conversación sobre literatura durante la clase de esta materia, experimentada como satisfactoria por los alumnos, apunta a la interpretación y a desentrañar el sentido de las obras; es una práctica bermenéutica, en la cual algunos textos "ajenos" (y muchas veces extraños al principio) se ponen en contacto con las cuestiones vitales propias. A pesar de toda la "crisis de la interpretación" que ha sido constatada por la ciencia literaria, los niños y los jóvenes parecen seguir teniendo la necesidad de formular y verificar por medio de la literatura sus interpretaciones referidas a ellos mismos y al mundo.

Perspectiva: oportunidades y tareas del fomento de la lectura

Finalmente quisiera preguntar qué conclusiones se pueden sacar de la perspectiva biográfica de la investigación de la lectura para las posibilidades y medidas de fomento escolar y extra-escolar de la lectura. La primera conclusión es la siguiente: el fomento de la lectura y la clase de literatura tienen que trabajar primero en la construcción de una motivación de lectura estable; solamente sobre esta base tiene sentido ampliar la competencia de lectura. En la escuela sigue sucediendo casi siempre lo contrario, y esto en todos los niveles escolares, empezando por la adquisición del lenguaje escrito (aprender a leer y escribir) en la primaria, hasta la clase de literatura en el nivel superior del bachillerato.

En segundo lugar: así como el medio del libro está incluido actualmente dentro de "asociaciones objetivas de medios" por el lado del producto (el "libro de la película", etcétera) y en "asociaciones subjetivas de medios" por el lado del receptor, también la clase de literatura o 
las ofertas extra-escolares para el fomento de la lectura deberían servirse de una combinación e integración de medios, en lugar de utilizar los medios uno contra otro: la filmación de la literatura, la escenificación teatral, o la elaboración de una versión de radio-teatro se incluyen en este punto, al igual que la investigación en Internet o la elaboración de hiper-textos multimediales con base en obras literarias. Esto implica un manejo no solamente receptivo, sino al mismo tiempo también productivo y actuante, de la literatura.

En tercer lugar: respecto a las fases de desarrollo esbozadas acerca de la biografía de lectores, se puede decir lo siguiente: en la infancia, o sea en la edad de la escuela primaria, un fomento de la lectura que prometa tener éxito tiene que conectarse con el modo de lectura de la "lectura infantil placentera"; aquí se trata sobre todo de mostrarles a los niños que no han podido hacer esta experiencia en su casa paterna, que escuchar historias leídas por otros, y leerlas uno mismo, es una placentera y enriquecedora forma de recibir los medios. Dado que la lectura sirve aquí sobre todo a la satisfacción de la fantasía, se ofrecen materiales del ámbito de la literatura infantil de lo fantástico y de aventuras (iHarry Potter!), pero también los "clásicos" de la literatura infantil, como Astrid Lindgren, Erich Kästner, y otros. En la clase de literatura resulta especialmente difícil llegar a los adolescentes al final de la infancia y en la pubertad, o sea, en el nivel secundario I. Los materiales que ellos devoran por propia iniciativa de forma adictiva (literatura trivial, cómics, literatura de fascículos y series) deberían ser respetados por la escuela, y ésta no debería convertirlos en objeto de "análisis críticos" en la clase. Los dramas, cuentos y novelas que se leen usualmente en este nivel escolar, tomados del inventario de la tradición literaria, en la mayoría de los casos no toman en cuenta en absoluto los intereses de los adolescentes, y muchas veces destruyen todo interés por la clase de literatura (p. ej., el Guillermo Tell, de Schiller, o El Haya de los Judíos, de Droste-Hülshoff, etcétera); para esta fase son más recomendables la literatura juvenil moderna, o bien textos sobre complejos temáticos que sean interesantes para los jóvenes. En cambio, un acercamiento prometedor hacia la "literatura canónica" del pasado y el presente solamente puede tener buenos resultados a partir de la fase de la "segunda iniciación literaria"; 
es decir, en la adolescencia o al terminar el nivel secundario I, y en el nivel secundario II. Y también aquí la escuela debería abrirle a los jóvenes el acceso a un amplio espectro de literatura (desde el "Werther" de Goethe hasta la literatura actual, desde los dramas de la antigüedad hasta la moderna novela de adolescentes), y a un espectro igualmente amplio de estrategias de lectura y modos de lectura, que tendrían que estar disponibles según las situaciones y las necesidades. Entre éstas se cuenta el modo de la lectura instrumental (p. ej., bajo la forma de la competencia para realizar una investigación direccionada para obtener información), al igual que el modo de la participación literaria, por ejemplo, la utilización de la literatura y los libros de información como "ayuda vital" o como medio para explicarse a sí mismo y al mundo; el modo de la "lectura conceptual", o a veces incluso de la "lectura obligatoria" ordenada desde fuera, así como el modo de la "lectura sin objetivo", para lograr un disfrute estético, o por el placer de obtener conocimientos (p. ej., en la poesía o en los textos filosóficos). El modo de la lectura íntima por placer debería ser respetado por la escuela, pero es aquél al que menos acceso tiene ésta como institución.

Una clase de literatura con muchas variantes y rica en sugerencias, tanto respecto a los materiales de lectura como a las formas de comunicación y modos de apropiación, sería deseable en la escuela bajo el punto de vista de un fomento efectivo de la lectura, pero hasta el momento no se ha convertido para nada en realidad, como lo muestran numerosas autobiografías de lectura de mis estudiantes, de quienes hasta ahora aproximadamente uno de cada dos se queja de haber tenido en su escuela una clase de literatura aburrida, poco inspirada y que muchas veces incluso los hizo alejarse con horror de la materia. 


\section{BIBLIOGRAFÍA}

Bamberger, Richard (2000): Erfolgreiche Leseerziehung in Theorie und Praxis. Mit besonderer Berücksichtigung des Projekts "Leistungs- und Motivationssteigerung im Lesen und Lernen unter dem Motto Lese- und Lernolympiade“. Wien: öbv \& hpt; 2000

Behnken, Imbke; Messner, Rudolf; Rosebrock, Cornelia; Zinnecker, Jürgen (1997): Lesen und Schreiben aus Leidenschaft. Jugendkulturelle Inszenierungen von Schriftkultur. Weinheim und München: Juventa 1997

Bertelsmann Stiftung (Hg.) (2000): Lesen fördern in der Welt von morgen. Modelle für die Partnerschaft von Bibliothek und Schule. Gütersloh: Verlag Bertelsmann Stiftung 2000

Bonfadelli, Heinz; Bucher, Priska (Hg.) (2002): Lesen in der Mediengesellschaft. Stand und Perspektiven der Forschung. Zürich: Pestalozzianum 2002

Deutsches PISA-Konsortium (Hrsg.) (2001): PISA 2000. Basiskompetenzen von Schülerinnen und Schülern im internationalen Vergleich. Opladen: Leske u. Budrich 2001

Eggert, Hartmut; Garbe, Christine (2003): Literarische Sozialisation. 2. aktualisierte Auflage. Stuttgart/Weimar: Metzler 2003

Eggert, Hartmut; Garbe, Christine; Krüger-Fürhoff, Irmela Marei; Kumpfmüller, Michael (2000): Literarische Intellektualität in der Mediengesellschaft. Empirische Vergewisserungen über Veränderungen kultureller Praktiken. Weinheim und München: Juventa 2000

Feierabend, Sabine / Klingler, Walter (2000): Jugend, Information, (Multi-)Media 2000. In: Media-Perspektiven, Heft 11, S. 517-527.

Fend, Helmut (1979): Sozialisation durch Literatur. Soziologie der Schule IV. Weinheim u. Basel: Beltz 1979

Garbe, Christine (2003a): Mädchen lesen ander(e)s. Für eine geschlechterdifferenzierende Leseförderung. In: JuLit. Informationen des Arbeitskreises für Jugendliteratur, Heft 2/2003, S. 14-29 
Garbe, Christine (2003b): Alle Mann ans Buch! Aufgaben einer geschlechterdifferenzierenden Leseförderung. In: JuLit. Informationen des Arbeitskreises für Jugendliteratur, Heft 3/2003, S. 45-49

Garbe, Christine; Graf, Werner; Rosebrock, Cornelia; Schön, Erich (Hrsg) (1997): Lesen im Wandel. Probleme der Literarischen Sozialisation heute. Didaktik Diskurse Bd. 2. Lüneburg 1997

Graf, Werner (1995): Fiktionales Lesen und Lebensgeschichte. Lektürebiographien der Fernsehgeneration. In: Rosebrock, Cornelia (1995), S. 97-125

Graf, Werner (1997a): Lesen und Biographie. Eine empirische Fallstudie zur Lektüre der Hitlerjugendgeneration. Tübingen und Basel: Francke 1997

Graf, Werner (1997b): Das Schicksal der Leselust. Die Darstellung der Genese der Lesemotivation in Lektüreautobiographien. In: Garbe et al. 1997, S. 101-124

Graf, Werner (2001): Lektüre zwischen Literaturgenuss und Lebenshilfe. Modi des Lesens. In : Leseverhalten in Deutschland im neuen Jahrtausend, S. 199-224

Groeben, Norbert (Hg.) (1999a): Lesesozialisation in der Mediengesellschaft. Ein Schwerpunktprogramm. 10. Sonderheft des Internationalen Archivs für Sozialgeschichte der deutschen Literatur (IASL). Tübingen: Niemeyer 1999

Groeben, Norbert (Hrsg.) (1999b): Lesesozialisation in der Mediengesellschaft: Zentrale Begriffsexplikationen. Kölner Psychologische Studien. Beiträge zur natur-, kultur-, sozialwissenschaftlichen Psychologie. Jahrgang IV, 1999, Heft 1

Groeben, Norbert (Hrsg.) (2000): Interdisziplinäre Methodik der Lesesozialisationsforschung. Sonderheft des Siegener Periodicum zur Internationalen Empirischen Literaturwissenschaft (SPIEL), Jg. 18 (1999), Heft 1, Frankfurt/M.: Lang 2000

Groeben, Norbert; Hurrelmann, Bettina (Hrsg.) (2002a): Lesekompetenz. Bedingungen, Dimensionen, Funktionen. Weinheim und München: Juventa 2002 
Groeben, Norbert; Hurrelmann, Bettina (Hrsg.) (2002b): Medienkompetenz. Voraussetzungen, Dimensionen, Funktionen. Weinheim und München: Juventa 2002

HANDBUCH LESEN (1999): Im Auftrag der Stiftung Lesen und der Deutschen Literaturkonferenz hg. von B. Franzmann u.a.. München: Saur 1999

Harmgarth, Friederike (Hrsg.) (1997): Lesegewohnheiten - Lesebarrieren. Schülerbefragung im Projekt "Öffentliche Bibliothek und Schule - neue Formen der Partnerschaft.” Gütersloh: Bertelsmann 1997

Hurrelmann, Bettina (1994): Leseförderung. Basisartikel. In: Praxis Deutsch 127/1994, S. 17-26

Hurrelmann, Bettina (1999): Sozialisation: (individuelle) Entwicklung, Sozialisationstheorien, Enkulturation, Mediensozialisation, Lesesozialisation (-erziehung), literarische Sozialisation. In: N. Groeben 1999b, S. 105-115

Hurrelmann, Bettina (2002a): Zur historischen und kulturellen Relativität des "gesellschaftlich handlungsfähigen Subjekts" als normativer Rahmenidee für Medienkompetenz. In: N. Groeben / B. Hurrelmann 2002b, S. 111 - 126

Hurrelmann, Bettina (2002b): Leseleistung - Lesekompetenz. Folgerungen aus PISA, mit einem Plädoyer für ein didaktisches Konzept des Lesens als kultureller Praxis. In: Praxis Deutsch 176 (29. Jg.) Nov. 2002, S. 6-18

Hurrelmann, Klaus / Ulich, Dieter (Hrsg.) (1991): Neues Handbuch der Sozialisationsforschung. Weinheim u. Basel: Beltz 1991 (4. völlig neu bearb. Aufl.)

Iser, Wolfgang (1972): Der implizite Leser. Kommunikationsformen des Romans von Bunyan bis Beckett. München: Fink 1972

Iser, Wolfgang (1984): Der Akt des Lesens. Theorie ästhetischer Wirkung. - 2. durchges. u. verb. Aufl. - München: Fink 1984 
Iser, Wolfgang (1991): Das Fiktive und das Imaginäre. Perspektiven literarischer Anthropologie. Frankfurt/M.: Suhrkamp 1991

Jauß, Hans Robert (1982): Ästhetische Erfahrung und literarische Hermeneutik. Frankfurt/M.: Suhrkamp 1982

Lesesozialisation. Studien der Bertelsmann Stiftung (1993):

Bd. 1: Hurrelmann, Bettina; Hammer, Michael; Nieß, Ferdinand: Leseklima in der Familie (unter Mitarbeit von S.Epping und I.Ofteringer)

Bd. 2: Bonfadelli, Heinz; Fritz, Angela; Köcher, Renate: Leseerfahrungen und Lesekarrieren (mit einer Synopse von U. Saxer). Enthält die Studien von Bonfadelli/Fritz: Lesen im Alltag von Jugendlichen (S.7-213) und Köcher: Lesekarrieren - Kontinuität und Brüche (S. 215-310). Gütersloh: Bertelsmann 1993

Pöppel, Ernst (2002): Die unnatürlichste Tätigkeit des Gehirns. [Gespräch mit Dieter Banzhaf.] In: Universitas. Orientierung in der Wissenswelt. Schwerpunkt: "Zukunft des Lesens". 57. Jg., H. $673 / 2002$, S. $747-751$

Ring, Klaus; von Trotha, Klaus; Voß, Peter (1997): Lesen in der Informationsgesellschaft - Perspektiven der Medienkultur. BadenBaden: Nomos 1997 ("Resolution zur Lese- und Medienkultur heute": ebd., S. 155-158)

Rosebrock, Cornelia (Hg.) (1995): Lesen im Medienzeitalter. Biographische und historische Aspekte literarischer Sozialisation. Weinheim: Juventa 1995

Rosebrock, Cornelia (2003): Wege zur Lesekompetenz. Reading Literacy und literarische Sozialisation. In: Beiträge Jugendliteratur und Medien, Heft 2, 2003

Schön, Erich (1989): Leseerfahrungen in Kindheit und Jugend. In: Lehren und Lernen 15/1989, H. 6, S. 21-44

Schön, Erich (1990): Die Entwicklung literarischer Rezeptionskompetenz. Ergebnisse einer Untersuchung zum Lesen bei Kindern und Jugendlichen. In: SPIEL, Jg. 9, Heft 2, S. 229-276. 
Schön, Erich (1993): Jugendliche Leser und ihr Deutschunterricht. In: H. Balhorn; H. Brügelmann (Hg.), Bedeutungen erfinden im Kopf, mit Schrift und miteinander. Zur individuellen und sozialen Konstruktion von Wirklichkeiten. Konstanz: Faude 1993, S. 220-226

Schön, Erich (1995): Veränderung der literarischen Rezeptionskompetenz Jugendlicher im aktuellen Medienverbund. In: Lange, Günter / Steffens, Wilhelm (Hg.): Moderne Formen des Erzählens in der Kinder- und Jugendliteratur der Gegenwart unter literarischen und didaktischen Aspekten. Würzburg 1995, S. 99-127.

Schön, Erich (1998): Kein Ende von Buch und Lesen. Entwicklungstendenzen des Leseverhaltens in Deutschland- Eine Langzeitbetrachtung. In: Stiftung Lesen (Hg.): Lesen im Umbruch Forschungsperspektiven im Zeitalter von Multimedia. Baden-Baden 1998, S. 39-77.

Stiftung Lesen; SPIEGEL-Verlag (Hrsg.) (2001): Leseverhalten in Deutschland im neuen Jahrtausend. Eine Studie der Stiftung Lesen. Hamburg 2001

Wieler, Petra (1997): Vorlesen in der Familie. Fallstudien zur literarisch-kulturellen Sozialisation von Vierjährigen. Weinheim und München 1997

Willenberg, Heiner (1999): Lesen und Lernen. Eine Einführung in die Neuropsychologie des Textverstehens. Heidelberg: Spektrum 1999. 


\title{
Allende los linderos. Hacia la integración de enfoques en los estudios de la lectura y la escritura
}

\author{
Didier Álvarez ZAPATA
}

\section{INTRODUCCIÓN}

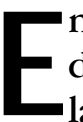

un contexto de supuesta crisis de la experiencia de vida indivitual y colectiva, este trabajo explora algunas representaciones de a lectura y la escritura, con la perspectiva de plantear un enfoque integral que permita comprenderlas más cabalmente como prácticas sociales, culturales y políticas. Para ello, las considera como fenómenos que no es conveniente estudiar solamente desde el enfoque que hemos calificado como operacional comprensivo, y que encierra el peligro de instrumentalizarlas dentro de un discurso pedagógico cada vez más centrado en la idea de competencias y babilidades comprensivas, sino desde una perspectiva sociocultural y política, en la que leer y escribir se tornan en complejísimas prácticas mediadas, fundamentalmente, por hechos propios de lo que Habermas llama el mundo de la vida y del sistema político. ${ }^{1}$ Consideradas como tales, leer y escribir se harían objetos transdisciplinares en los que las diversas áreas sociales, humanísticas y tecnológicas renovarían sus discursos y metodologías de investigación. En particular, se harían un territorio lleno de posibilidades de reconfiguración para la bibliotecología y la

1 Al respecto, véase principalmente la obra:

Jurgen Habermas. Problemas de legitimación en el capitalismo tardío. Buenos Aires : Amorrortu, 1991. 248 p. 
ciencia de la información, en función de una más clara comprensión de sus responsabilidades culturales, sociales y políticas.

En particular, creemos que desde un enfoque como el propuesto, sí sería posible colectivamente abordar el estudio de fenómenos tan intrincados como los que se vislumbran en la llamada crisis de la lectura, y que se han vuelto lugar común en las representaciones sociales y políticas sobre el leer y el escribir en nuestro continente.

\section{HACIA UNA CRÍTICA DE LAS REPRESENTACIONES SOCIALES DE LA LECTURA Y LA ESCRITURA}

Ya hemos tenido la ocasión de referirnos, en otros trabajos, a la puesta en escena de la lectura y la escritura que se viene dando en el ámbito latinoamericano y, en especial, en el campo bibliotecario. ${ }^{2}$ Con todo, debe decirse que esa aparición pública de la idea de lectura y escritura en nuestra región parece desenvolverse en dos posiciones extremas. Por un lado persiste en amplios sectores de la sociedad y el Estado la idea de que éstas son prácticas "importantes y necesarias”, que están ahí, pero sobre las cuales hay poco que preguntarse y

2 Habíamos señalado, en particular, cómo se procesa un evidente contexto de revigorización del significado sociocultural y político de la lectura en la región, dentro de lo cual la condición institucional de la biblioteca se ha visto fuertemente impactada, queriéndosele reivindicar como una institución valiosa en la construcción de una 'sociedad lectora'; es decir, como una institución fundamental en el logro de los propósitos de democratización del acceso de los 'ciudadanos' a la información y a la lectura.

$\mathrm{Al}$ respecto, ver en especial los trabajos:

- Didier Álvarez Zapata y Juan Guillermo Gómez García. El discurso bibliotecario público sobre la lectura en América Latina (1950-2000): una revisión preliminar con énfasis en Colombia, En: Revista Interamericana de Bibliotecología. Medellín. Vol. 25, no. 1 (En. - Jun. 2002).

- Didier Álvarez Zapata, Luis Bernardo Yepes Osorio y Adriana Betancur Betancur. La biblioteca pública en América Latina. En: Hojas de Lectura. Bogotá. No. 51 (Abr.-Jun. 1998); p.2-6 
mucho menos que decir. Podría calificar a esta idea, como la generadora de una visión ingenua y reduccionista de la lectura y la escritura. Amparados en ella, muchos padres de familia, maestros, bibliotecarios y gobernantes jamás se han preguntado en qué consiste ni cuál es el fundamento de su "importancia". Por el otro lado se encuentran las ideas sobredimensionadas de la lectura y la escritura dentro de las cuales se desataca, con ventaja, la representación de la lectura como la pieza clave en el desarrollo, como la piedra angular en la superación de la ignorancia, un elemento, en fin, milagroso que por sí mismo erradicaría todos los males sociales, como se proponía en los Primeros Encuentros Regionales de Lectura y Escritura celebrados en Colombia en 2002,

[...]resguardaos en esta visión, en efecto, algunas instituciones vinculadas al Estado diseñan publicitadas campañas de alfabetización que, a la postre, representan recursos que se pierden porque los nuevos "lectores" no saben ni encuentran qué hacer con esa competencias en su cotidianidad, y, en muchos casos (que es lo más grave), no tienen a su alcance materiales de lectura con qué ejercitarlas. ${ }^{3}$

De cualquier manera, estas dos visiones exigen una profunda reconsideración de la forma en que a partir de la investigación y el ejercicio profesional educativo y bibliotecológico (por no decir que desde las ciencias sociales en general) se aborda el problema del leer y del escribir. Creemos pertinente, al respecto, promover una mayor integración de las perspectivas investigativas de la lectura y la escritura, por considerar que sus intereses de estudio son confluyentes e inseparables. De tal suerte, siguiendo una metáfora cercana a todos, podríamos decir que el problema de los estudios de la lectura y la escritura tiene, como una moneda, dos caras y un canto que conecta esas dos caras: el haz, esto es, la cara que ha resultado más evidente y atractiva para los investigadores, estaría relacionado con la necesidad de entender las maneras en que opera la comprensión lectora. Esa cara sería el dominio de

3 ASOLECTURA. Resultados de los Primeros Encuentros regionales de Lectura y Escritura. Colombia 2002. Bogotá : Asolectura, 2002. 43 p. 
la psicolingüística, que se interesa fundamentalmente por dar cuenta de los procesos de formación e integración del pensamiento y el lenguaje, en la línea de la construcción de la significación. El envés, su faz menos evidente y elaborada, estaría conformado por la incipiente necesidad de reconocer y entender los factores determinantes y las consecuencias socioculturales y políticas de la lectura y la escritura en una sociedad particular.

Como puente, fusión y límite entre el haz y el envés de la moneda, está esa materia subsumida y oculta sobre la cual se acuña el canto, y que sólo se nos hace evidente en los cortes de la moneda (normalmente circular, y por ello puesta en otra dimensión distinta y mucho más simbólica, sin duda) que la de las caras. Así pues, hay que decir que nuestra moneda "lectura y escritura" no estaría completa sin su canto. Precisamente, siguiendo la metáfora, éste estaría constituido por el conjunto de saberes y prácticas del orden pedagógico en los que se encontrarían dos niveles o instancias de intervención educativa: la educación formal escolar y la animación sociocultural (pedagogía social y educación popular). ${ }^{4}$

Sin duda, la perspectiva de la lectura y la escritura estudiadas tan asidua y fructíferamente por la psicolingüística durante décadas, nos parece que no han sido suficiente (quizá por sus intereses y énfasis) para entender problemas tan arduos como los referidos, por ejemplo, a las maneras en que leer y escribir se vuelven parte de las estrategias de acción cultural que las personas despliegan para hacer o deshacer una cierta idea y facticidad del mundo, para habitar o deshabitar un cierto lugar en el mundo desde la palabra ${ }^{5} \mathrm{o}$, más agudamente, las formas en que leer y escribir se integran a los procesos de socialización y regularización de la dominación política, legitimación del poder y las demandas de legitimidad que vienen de los sistemas y regímenes

4 Por cierto, las prácticas bibliotecarias dirigidas al fomento de la lectura constituyen una forma de esa intervención pedagógica ya referidas a contextos escolares regulares o a contextos de animación sociocultural o de educación popular.

5 Emile Cioran lo decía sin ambages: "no habitamos un país, habitamos una lengua". 
políticos hacia los ciudadanos (asuntos tan caros, por cierto, en las propuestas políticas de la bibliotecología socialista y presentes, también, pero de manera menos explícita, en la bibliotecología anglosajona más clásica).

Ante todo ello, creemos necesario enfatizar la necesidad de mirar en detalle esa faz de la lectura y la escritura en que se las perfila como prácticas de orden sociocultural y a las cuales se debe comprender desde un conjunto esencial de preguntas: ¿por qué se lee, para qué se lee, y cómo leer y escribir ayudan a construir una imagen o presencia social de los sujetos? Así pues, es urgente aludir a la lectura y a la escritura como prácticas, por estar estas acciones intencionalmente dotadas de valores y sentidos sociales, culturales y políticos específicos; es decir, prácticas que se desarrollan con sentidos, intenciones, contextos y tendencias determinadas históricamente.

\section{¿QUÉ PUEDE ENTENDERSE POR LEER Y POR ESCRIBIR DESDE UN ENFOQUE SOCIOCULTURAL Y POLÍTICO?}

Primero que todo es importante recordar que leer y escribir no son "operaciones" que puedan ser resueltas mediante la fácil ecuación, comúnmente recurrida, que las explica como operaciones inversas; es decir, como un simple juego de imágenes y contraimágenes. La representación más contemporánea de las relaciones entre lectura y escritura, las considera como correlatos dentro de un complejo proceso de producción y consumo social de información y conocimiento. Todavía más, y como lo anota Martínez, las prácticas del leer y el escribir "están dirigidas a posibilitar la interacción entre personas. La interacción es entendida como la solución del problema de cómo planes de acción de varios actores pueden coordinarse entre sí". ${ }^{6}$

6 María Cristina Martínez. El discurso escrito, base fundamental de la educación y la polifonía del discurso pedagógico. En: Entre la lectura y la escritura : hacia la producción interactiva de los sentidos. Bogotá : Cooperativa Editorial Magisterio, 1997. p. 153 
En este sentido, ni la escritura es un simple proceso de codificación, ni la lectura es un proceso plano de descodificación. Podría decirse que la construcción de significación (con la intención de la transformación de las condiciones actuales de vida) es el elemento unificador de la lectura y la escritura. Leer y escribir significativamente es una consigna cultural que reivindica a la lectura como un hecho tan productivo de sentido como lo es la escritura. Dicho de una manera más simple, los vínculos productivos de la lectura y la escritura (desde esta perspectiva dinámica-correlacional) se hacen evidentes en tanto que la cultura vivida como construcción de sentido, exige leer para escribir, escribir para leer y, leer y escribir para transformar

Así pues, enfatizamos que nuestra idea de lectura y escritura está más allá de mostrarlas como simples acciones de descodificación - codificación de ideas. Y en consecuencia afirmamos que, desde una perspectiva sociocultural, leer y escribir son actos por medio de los cuales se hace uso de la voz que como sujeto se tiene, y que puede ser usada culturalmente. ${ }^{7}$ Con todo, la escritura tiene y ha tenido una consideración sociocultural y política harto distinta y distante de la lectura. En efecto, desde esta consideración escribir se representa como voz y leer se significa como escucha. Escribir es tener presencia y perdurabilidad, leer es vivir presentes normalmente anónimos e intimistas, de la mano de las ideas de un sujeto visibilizado públicamente.

7 Esta idea se apoya en los muy valiosos trabajos de la corriente de la pedagogía crítica. En especial, en los textos:

- Fernnado Barcena y Joan-Carles Melich. La educación como acontecimiento ético : natalidad, narración y hospitalidad. Barcelona : Paidós, 2000. 206 p.

- Paulo Freire. A importancia do ato de ler: em tres artigos que se completam Paulo Freire. Sao Paulo : Coaez Editora : Autores editores, 1986. 235 p.

- Henry Giroux. La alfabetización y la pedagogía de la habilitación política. En: Paulo Freire, y Donaldo Macedo. Alfabetización: lectura de la palabra y lectura de la realidad. Barcelona : Paidós, 1989. pp. 25-50 
En consecuencia, nuestra propuesta radica en que nuestra idea de escritura es la de una práctica correlacional a la lectura, su par dialéctico dentro de una díada que le permite a las personas tener voz, recuperar (se) y contar (se) en su historia.

Así, cuando calificamos a lectura y escritura como prácticas socioculturales, se está haciendo alusión a un conjunto de hechos y situaciones, en ellas y por ellas suscitados, relacionados con los efectos socializantes y simbólicos que tienen (funciones, finalidades, valoraciones, usos), referidos a cómo la lectura y la escritura ayudan a construir una imagen o presencia social y política de los sujetos.

En este sentido entenderemos a la lectura como una práctica que habilita a las personas para interactuar con un texto (en cualquiera de sus modalidades o conformaciones: oral, escritural, audiovisual o multimedial) y producir significados, dentro de un contexto sociocultural, político e histórico preciso. De tal manera, leer se asume como el proceso cognitivo, semiótico, cultural, social e bistórico de carácter complejo e interactivo entre el mensaje expuesto en el texto (que no sólo es el escrito) y el conocimiento, las expectativas y los propósitos del lector, dentro de contextos sociales, culturales, politicos e bistóricos determinados.

Para entender la práctica lectora seguiría siendo pertinente el estudio de los tres elementos ya señalados, desde tiempo atrás, en los enfoques contemporáneos de la lectura y la escritura pero que aquí pensamos indispensable resignificar desde los estudios culturales, sociales y políticos. ${ }^{8}$

8 Estas ideas desarrollan algunas propuestas teóricas hechas en el trabajo de investigación:

Didier Álvarez Z., Adriana Betancur B. y Luis Bernardo Yepes O. Diagnóstico de la promoción de la lectura en las bibliotecas públicas de Medellín y el Valle de Aburrá. Medellín : Universidad de Antioquia. Escuela Interamericana de Bibliotecología, 1994. 


\section{Gráfica 1}

Factores que constituyen la práctica lectora

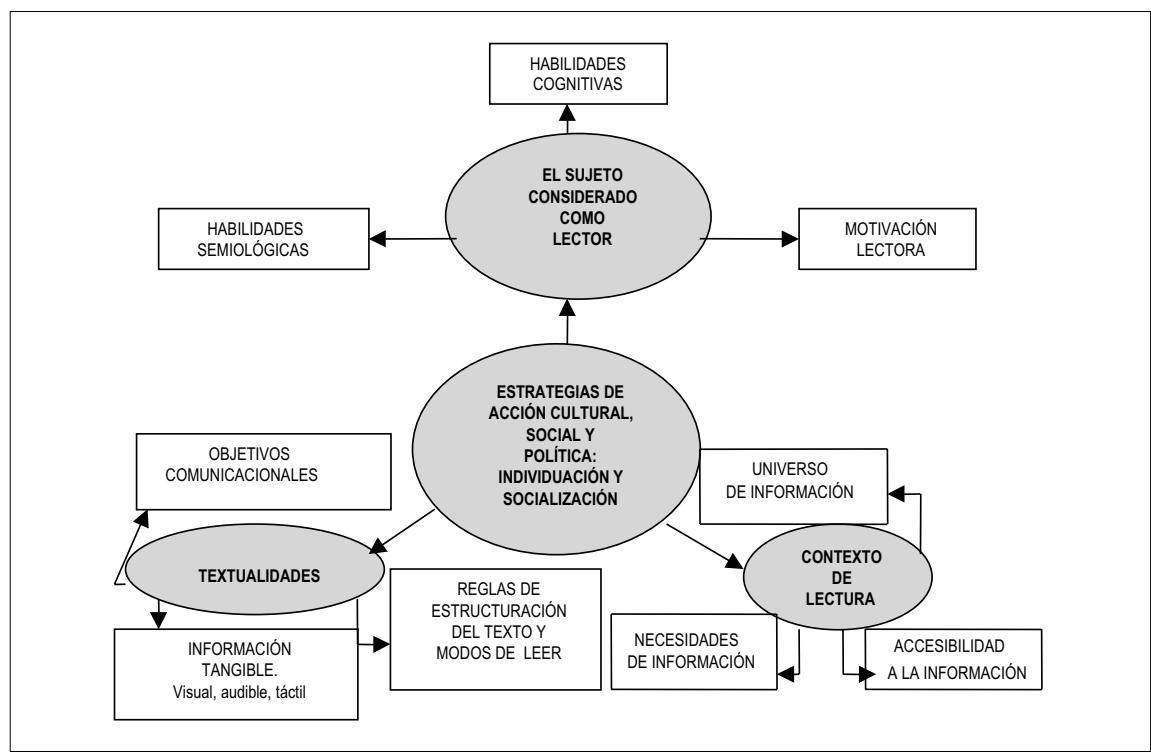

Sin duda, explicar desde un enfoque integrado cada uno de los elementos propuestos en la anterior gráfica, desbordaría las posibilidades de extensión de este trabajo, y constituye en sí el plan investigativo que nos hemos propuesto desde tiempo atrás. Con todo trataremos de perfilar, en general, lo que una visión de este tipo trae como consecuencias para hacernos considerar la lectura y escritura como objetos de estudio transdisciplinares. En este sentido, la lectura y la escritura, serían consideradas como prácticas que son:

- Prácticas de orden sociocultural y político, no reducibles a la función de dispositivo didáctico.

- En consecuencia, fenómenos históricos fuertemente cargados de contenidos ideológicos, normativos y prescriptivos y, por lo tanto, delineables (y efectivamente, delineados) por los diversos discursos políticos. 
- Mediadores culturales que sirven a las personas para poder hacerse y construir ciertas estrategias de acción cultural (en una perspectiva de sociabilidad; es decir, de vínculos sociales construidos y reconstruibles), y como medios de construcción de su propia vida íntima (en una perspectiva de individuación).

- Prácticas que no representan lo mismo que la alfabetización. Este territorio conceptual se agita desde ya hace mucho tiempo. La idea de alfabetización como algo más que leer y escribir, si bien es aceptada por "todos", se vuelve motivo de grandes disputas políticas cuando se la mira, precisamente, desde la perspectiva de la cultura política y la formación ciudadana.

- Objetos de investigación transdisciplinar y, en específico, objetos diferenciados en los estudios culturales referidos al comportamiento social (en tanto que en éstos, más que hablar de bábitos de lectura, se habla de comportamiento lector).

- Prácticas socioculturales que se vinculan a un universo interinstitucional amplio y complejo. Universo que sirve, de hecho, como referente ineludible de los programas de formación ciudadana.

- Prácticas socioculturales que están determinadas por las maneras que los sujetos tienen de representarlas, así como por las intencionalidades culturales y políticas con las que aquellos las difunden y las enseñan.

- Prácticas socioculturales que están determinadas, aun más específicamente, por los diseños pedagógicos y didácticos en los que los sujetos involucrados en los procesos de educación lectora (animadores y animados) se ven interactuando. De hecho, las personas pueden leer y escribir desde perspectivas productivas o reproductivas; es decir, transformativas o sustentadoras de un cierto orden de cosas.

- Prácticas socioculturales determinadas por las relaciones que se tejen, entretejen y destejen en la interacción de los sujetos con las diversas textualidades que hoy en día son múltiples y que llevan a preguntarse por los nuevos modos de leer y sus tensiones históricas, culturales, educativas y políticas. 
- Prácticas socioculturales determinadas por los efectos que nos han llevado a experimentar la masificación urbana, acelerada y traumática que hemos vivido en los últimos 50 años en América Latina.

\section{LAS POSIBLIDADES DE UN ENFOQUE INTEGRADO DE ESTUDIO DE LA LECTURA Y LA ESCRITURA: LA HIPÓTESIS DE SU CRISIS CONTEMPORÁNEA}

Los factores anteriormente propuestos constituyen el marco complejo dentro del cual sería posible comenzar a entender el actual estado de cosas sobre el leer y el escribir. Nos referimos, en específico, a una situación que de manera generalizada nos preocupa a todos: la supuesta crisis de la lectura y de la escritura. En efecto, debe decirse que ya entendidas éstas como prácticas complejas del orden sociocultural y político, viven en sí mismas las fuertes tensiones de un mundo que hoy no pocos investigadores interpretan como un momento precisamente de crisis del proyecto moderno. De cualquier manera, y en términos amplios, puede afirmarse que la lectura y la escritura están sometidas a las actuales variaciones del horizonte espaciotemporal desde el cual hombres y mujeres ven y quieren ver el mundo. De ello se desprende una idea central: la crisis de la modernidad y la irrupción de nuevas ideas sobre el hombre y el mundo constituyen un marco ampliamente complejo y útil a partir del cual se pueden mirar las maneras como las personas se abocan a redefinir, reconstruir y, en todo caso, a revisar las maneras como se relacionan con la lectura y la escritura; es decir, las maneras como las representan y las usan.

En este sentido, es propio considerar como una hipótesis pertinente a todos los interesados en su estudio, el hecho de que contemporáneamente se ha venido configurando una cierta crisis acerca del leer y el escribir, que se habría plasmado en dos grandes dimensiones:

Una: La crisis de la lectura está en relación con la pérdida o incluso el rompimiento (en cualquier caso, una variación...) de los sentidos de la circulación social que tienen los materiales de lectura. Esta perspectiva ve una pérdida del sentido "civilizado" y "civilizador" de 
la lectura, de acuerdo con el molde de la cultura centroeuropea. El sentido de la lectura se pierde, principalmente, en dos frentes: en el de las relaciones entre lectura y vida colectiva (lectura como práctica de socialización), y entre lectura y vida individual (lectura como práctica de individuación).

En efecto, esta visión recoge un temor grande (diríase patético y plenamente vinculado a la desigualdad social y la exclusión) por el futuro de la lectura. Armando Petrucci, precisamente, plantea que "el porvenir de la lectura está en juego, no donde ésta es una práctica habitual y consolidada, sino donde no lo es". ${ }^{9}$ Esta preocupación alcanza para ver cómo persisten hoy desequilibrios que perturban los cimientos de la cultura occidental fuertemente atada a la lectura y escritura como prácticas civilizatorias por excelencia.

La crisis de la lectura estaría plasmada en los crecientes niveles de analfabetismo, la baja calidad de la educación lectora, la disminución de la cantidad de "lectores experimentados" y, sobre todo, en la crisis del mercado editorial. Detrás de ello, un asunto más pavoroso aún a los ojos de los críticos: la devaluación pública del canon clásico de lectura que representaba el proyecto civilizatorio de occidente, en aras del anticanon ("con tal de que se lea, cualquier cosa es buena"). Crisis que se substancializa en lo que Petrucci llama, "leer por leer" o de cómo las personas guardan una actitud supuestamente hedonista hacia la lectura que los lleva al consumo individualizante, y a no reconocer en ella los viejos ideales ilustrados que la presentaban como herramienta de aprendizaje de cosas socialmente productivas y moralmente validadas. Ahora, incluso, los lectores rechazan los intentos de condicionamiento y reclaman abiertamente su derecho "inalienable" a leer cualquier cosa, en cualquier parte y de cualquier modo. He ahí, según Petrucci, al lector actual: "posmoderno, anárquico y egocéntrico".

9 Armando Petrucci. Leer por leer: un porvenir para la lectura. En: Guglielmo Cavallo, et al. Historia de la lectura en el mundo occidental. Madrid : Taurus, 1998. p. 519-520 
En esto hay que advertir, por cierto, que los jóvenes son vistos, en medio de esa supuesta crisis de la lectura, como los consumidores más débiles y culturalmente manipulables. A la vez, objetivo y causa de la irracional avalancha de imágenes y sonidos que están desplazando la "lectura" (de lo escritural), o mejor, reconfigurándola en prácticas lectoras fragmentadas, diluidas y carentes de reglas (...de las reglas del canon.) ${ }^{10}$

Y dos: La crisis de la lectura se da en razón del descentramiento de la textualidad escritural en relación con las otras textualidades emergentes (audiovisual y multimedial). Más recientemente, algunos autores interesados en la investigación sociológica, cultural, comunicacional e histórica de la lectura (Roger Chartier, Jesús Martín Barbero, Armando Petrucci, Luis Bernardo Peña, ${ }^{11}$ entre otros) aluden a la existencia de un cierto conjunto de fenómenos asociados con los cambios (pasados y presentes) en las maneras de leer. Pero tales alusiones, a nuestro parecer, suelen ser confusas conceptualmente e insuficientes ante la complejidad dentro de la cual se ubican los fenómenos de cambio en las textualidades.

En síntesis, esta perspectiva de la hipótesis de la existencia de una crisis de la lectura ve en la aparición de nuevas tecnologías del texto (hipertexto) y de nuevos modos de leer, la piedra de toque de la crisis actual de la lectura.

10 El problema del "canon" es un asunto que cada vez más toma las perspectivas de una discusión pública. Para ello sólo basta mirar la creciente demanda de guías de lectura y de recomendados disponibles en la prensa, las librerías y las bibliotecas. Hay, sin duda alguna, temor mortal de que se lea cualquier cosa aun cuando la oferta editorial es, abiertamente, promotora de esa lectura "descuidada". De todo ello es buen ejemplo el trabajo del profesor Bloom y sus respuestas a ¿cómo leer y por qué?. Véase:

- Harold Bloom. Cómo leer y por qué. Bogotá : Norma, 2002. 337 p.

11 De la larga lista de trabajos de estos autores, remitiremos a los lectores a los que mejor podrían mostrar la idea que exponemos aquí. Se encuentran descritos en la bibliografía de este trabajo. 
De hecho, cada una las dos perspectivas presentadas trata de resolver la supuesta crisis de la lectura, diciendo que, por el lado de la crisis como pérdida de sentido, el libro debe permanecer como último bastión del pensamiento crítico en oposición al hipertexto (libro multimedial) en tanto que fuente y objeto de espectacularización y masificación. Por su parte, la visión del descentramiento del libro afirma que la crisis se resolvería con la aceptación de las inimaginables posibilidades de ampliación de las funciones de la lectura que implica el hipertexto.

De cualquier manera, utilizando la bella imagen de Beatriz Sarlo, ${ }^{12}$ tanto la lectura lineal (lectura del libro) con orden fijo y regular, como la lectura esférica (la lectura hipertextual) sin orden ni centro fijos, permanecen y permanecerán en virtud de su necesidad y posibilidades.

$\mathrm{Al}$ respecto, creemos que es posible observar todos estos fenómenos de la crisis empleando un concepto amplio (y necesario) que abarque los extensos problemas que se incrustan en la reflexión actual de la lectura. Por ello queremos ahora mencionar algunas ideas generales de un concepto que estamos actualmente trabajando: el Modo de Producción y Consumo Textual (MPCT). ${ }^{13}$

En términos generales, el Modo de Producción y Consumo Textual es una determinada organización histórica del sistema de uso social de la información; esto es, de las maneras que tienen ciertos sujetos y grupos sociales específicos para producir, registrar, conservar, difundir y consumir información en una determinada época.

12 Beatriz Sarlo. Del plano a la esfera: libros e hipertextos. En: Martín Barbero, Jesús y López de la Roche, Fabio. Cultura, medios y sociedad. Bogotá : CES : Universidad Nacional de Colombia. Sede Bogotá, 1997. p. 65-76

13 Las ideas referentes a Modo de Producción y Consumo Textual, provienen del texto:

- Didier Álvarez Zapata. Del modo de leer como modo de producción y consumo textual: ideas fundamentales de una categoría en construcción. Revista Educación y Pedagogía. Universidad de Antioquia. Medellín. (Ene.-Jun. 2002); p. 135-152 
Todo Modo de Producción y Consumo Textual surge, se configura y reconfigura, por las vías de la mezcla o disolución en otros, por el desgaste cultural, o por las vías de la evolución tecnológica o "muerte" (por el desuso que puede sufrir de alguno o algunos de sus elementos, por ejemplo) dentro de unas determinadas condiciones sociohistóricas. Así, el Modo de Producción y Consumo Textual es un elemento esencial en la sociabilidad política, en tanto que mediador central en las maneras que tienen los sujetos de informarse ${ }^{14}$ (visto esto como práctica vinculada a la construcción de sentidos del mundo político en una sociedad determinada). Dicho de otra manera, informarse es una práctica de carácter sociocultural y política, mediada por las maneras como se produce, comunica y consume información (es decir, por los diversos Modos de Producción y Consumo Textual).

En este sentido es posible reconocer diversos tipos de Modo de Producción y Consumo Textual que, aunque implique alguna tendencia hegemónica de alguno de ellos sobre los otros, resultan interactuando bajo principios de complementariedad en un momento histórico determinado:

El Modo de Producción y Consumo Textual ORAL está principalmente vinculado a las culturas donde la escritura no existe o es utilizada por una élite (religiosa, intelectual, económica) o donde la escritura no está generalizada en la cotidianidad de la familia, la escuela, el trabajo, los gremios, etcétera, como herramienta vinculada a la vida.

14 Retomamos las ideas de Soares y De Albuquerque, para aclarar cuál es nuestra idea del acto de informarse como un hecho social y político: informarse "precisa ser comprendida como una práctica social realizada por un sujeto cognitivo-social que desarrolla acciones de atribución y comunicación de sentido que, a su vez, pueden provocar transformaciones en las estructuras, tanto individuales como sociales, expresadas en nuevos estados de conocimiento". En:

- Suzyneide Soares Dantas y Mirian de Albuquerque Aquino. Ler e escrever: (in)informaçao de leitores na alfabetizaçao de adultos. En: Informaçao e Sociedade. Paraímba. Vol. 11, no. 1 (2001), pp. 215-230 
El Modo de Producción y Consumo Textual ESCRITO está vinculado a culturas en donde los niveles de alfabetización, la postalfabetización y, sobre todo, el uso cotidiano y vital de la lectura y la escritura, presentan como base característica la predilección por la textualidad escrita. Normalmente pueden encontrarse aquí las sociedades integradas con fuerza a la modernidad.

El Modo de Producción y Consumo Textual AUDIOVISUAL está vinculado a las sociedades contemporáneas en las que el componente icónico es central. Puede decirse que en un mundo globalizado como el actual existe una fuerte tendencia a la lectura de imágenes y sonidos. Los soportes característicos de este modo pueden ser reconocidos en la televisión, el video, el cine y los videojuegos...

El Modo de Producción y Consumo Textual MULTIMEDIAL se caracteriza por la integración múltiple del lenguaje oral, escrito, icónico y táctil. Se encarna en la computadora como artefacto, y sus soportes son el disco óptico y el CD-ROM.

\section{ALGUNAS IDEAS A FORMA DE CONCLUSIONES PARCIALES}

No debemos ver en la lectura y la escritura más que problemas de comprensión, eficiencias y eficacias cognitivas y lingüísticas, sino disponernos a integrarlas en estudios más amplios de orden social, cultural y político. Creemos que los actuales retos de conocimiento que implica la supuesta crisis de la lectura, no podrán ser enfrentados si no se abordan desde enfoques integrativos en donde los saberes de la antropología cultural, la sociología, la historia, las ciencias de la comunicación y de la información y la politología, aporten su saber sobre las maneras en que leer y escribir nos muestran los cambios y tendencias de lo humano, y nos ayuden a narrar e interpretar los múltiples y sinuosos senderos por los que transitan hoy la textualidad y la significación. Disciplinas que se estrechen, allende los linderos, en una tarea de vivificación de los sentidos del leer y el escribir hoy, y que conlleven una apuesta de humanización profunda de estas prácticas. A eso estamos llamados. 


\section{BIBLIOGRAFÍA}

ÁLVAREZ Zapata, Didier y Naranjo, Edilma. La animación a la lectura : manual de acción y reflexión. Medellín : Universidad de Antioquia, Escuela Interamericana de Bibliotecología, 2003; 62 p. (Bibliotecología y Lectura : no.1)

- - Por una política pública de lectura y escritura. Bogotá : Asolectura : Instituto Colombiano de Bienestar Familiar, 2002. 43 p.

- - . "Del modo de leer como modo de producción y consumo textual: ideas fundamentales de una categoría en construcción", en Revista Educación y Pedagogía. Medellín. (Ene-Jun. 2002)

ASOLECTURA. Resultados de los Primeros Encuentros regionales de Lectura y Escritura. Colombia: 2002. Bogotá Asolectura, 2002. 43 p.

CHARTIER, Roger, comp. Historia de la Lectura en el mundo occidental. Barcelona : Alianza, 1994; 123 p.

- - . El mundo como representación. Historia Cultural: entre práctica y representación. Barcelona : Gedisa,1992. 236 p.

FREIRE, Paulo. A importancia do ato de ler: em tres artigos que se completam Paulo Freire. Sao Paulo : Coaez Editora : Autores editores, 1986. $235 \mathrm{p}$.

GIROUX, Henry. "La alfabetización y la pedagogía de la habilitación política", en Freire, Paulo y Macedo, Donaldo. Alfabetización: lectura de la palabra y lectura de la realidad. Barcelona : Paidós, 1989. p. 25-50

MARTÍN Barbero, Jesús. "Descentramiento del libro y estallido de la lectura", en Congreso Nacional de Lectura . Lectura y Nuevas Tecnologías. ( $3^{\circ}$ : 1997 : Santafé de Bogotá). Ponencia del III Congreso Nacional de Lectura. Santafé de Bogotá, 1997, pp. 155, 157

-- . "Cambios culturales, desafíos y juventud", en Umbrales. Medellín : Región, 1998; p. 34 
MARTÍNEZ, María Cristina. "El discurso escrito, base fundamental de la educación y la polifonía del discurso pedagógico", en Entre la lectura y la escritura : hacia la producción interactiva de los sentidos. Bogotá : Cooperativa Editorial Magisterio, 1997. pp. 143-162

PEÑA Borrero, Luis Bernardo. "Saber leer otros lenguajes", en Alegría de Enseñar. No. 40 (Jul.- Sep. 1999), p. 39

PETRUCCI, Armando. "Leer por leer: un porvenir para la lectura", en Cavallo, Guglielmo Historia de la lectura en el mundo occidental. Madrid : Taurus, 1998, pp. 519-550

SARLO, Beatriz. "Del plano a la esfera: libros e hipertextos", en Martín Barbero, Jesús y López de la Roche, Fabio. Cultura, medios y sociedad. Bogotá : CES : Universidad Nacional de Colombia. Sede Bogotá, 1997; pp. 65-76

TRILlA Bernet, Jaume. Las otras educaciones: ASC, formación de adultos y ciudad educativa. Barcelona : Antrophos, 1993.

SWIDLER, Ann. "La cultura en acción: símbolos y estrategias", en Zona Abierta. No. 77-78 (1996-1997); p. 127-162. 


\title{
De la lectura y la escritura y sus relaciones con la política: algunas perspectivas de comprensión desde los lenguajes políticos
}

\author{
Didier ÁlVAREZ ZAPATA
}

La alfabetización debe concebirse como un medio que constituye y afirma los momentos bistóricos y existenciales de la experiencia vivida que genera una cultura sometida. Por lo tanto, constituye un fenómeno eminentemente político, y debe analizarse dentro del contexto de una teoría de las relaciones de poder y una comprensión de la producción y reproducción social y cultural

Paulo Freire ${ }^{1}$

\section{INTRODUCCIÓN}

hel territorio de los estudios políticos hay hechos, elementos y
Telaciones que se miran como insulsos, insignificantes o, en el
mejor de los casos, secundarios en comparación con otros asuntos de más calibre. Ello no es malo en sí mismo, pues sólo responde a la dinámica misma de la disciplina que debe, desde su desarrollo epistemológico, privilegiar los objetos de estudio que históricamente le son sensibles. De hecho, la ciencia política, la filosofía política y

1 Paulo Freire. La alfabetización y la pedagogía crítica. En : Freire, Paulo y Macedo, Donaldo. Alfabetización: lectura de la palabra y lectura de la realidad. Barcelona : Paidós, 1989; p. 144 
la sociología política, por ejemplo, han dedicado sus esfuerzos, sobre todo, al estudio de asuntos grandemente problemáticos y visibles, como los asociados directamente con los problemas del uso y las transformaciones del poder, la conformación del "orden" político, la elucidación de la participación política de las personas, los cambios, crisis, mutaciones y retos de los sistemas y los regímenes políticos, entre otras cosas.

Esto, obviamente, invisibiliza no pocos fenómenos que, mirados con atención, pueden resultar ricas vetas para los estudios políticos. Este es el caso, precisamente, con la lectura y la escritura que, abandonadas en su redil pedagógico tradicional, poco o nada dicen a los estudios políticos, pero que observadas más allá; es decir, como prácticas del orden cultural y social a través de la cual se concretan ciertos fenómenos políticos, tendrían que relacionarse, inevitablemente, con discursos cada vez más amplios como los de la formación ciudadana, la socialización política y la cultura política, entre otros. De hecho, desde ya hace un buen tiempo se posan miradas más atentas y auscultadoras sobre la lectura que, por ejemplo, pretenden dar cuenta de ideas y problemas relacionados con los discursos del lenguaje (y ahí dentro la lectura y la escritura...) y sus usos políticos.

En algunos sectores de la investigación social y política, precisamente, se empieza a ver en la lectura más de lo que se creía significante. Así, ahora, como lo dice Zilberman "la lectura se revela como un fenómeno históricamente delimitado y circunscrito a un modelo de sociedad que se vale de ella para su expansión. La consolidación de este modelo se relaciona con un repertorio de factores de orden económico, social, cultural e ideológico [político]". ${ }^{2}$

En efecto, cada vez es más urgente la necesidad de comprender las maneras en que partiendo de las prácticas culturales y sociales se procesan los asuntos políticos centrales como la aceptación de la

2 Regina Zilberman. "Sociedade e democratizaçao da leitura", en: Heitor Barzotto, Valdir, comp. Estado de leitura. Campinas, SP :Mercado de Letras : Associaçao de Leitura do Brasil, 1999. p. 31. 
dominación, la integración política, la legitimación de los sistemas políticos, la presencia pública de los sujetos, la conformación e integración ideológica y funcional de los ámbitos privado y público, la formación de opinión pública, y la formación ciudadana (de central interés actualmente) entendida como ámbito de integración de ideales educativos políticos dentro de cierta cultura política, y como despliegue de propuestas pedagógicas y la utilización de diferentes dispositivos de producción, negociación y consumo cultural de los sentidos públicamente disponibles (precisamente, la lectura y la escritura, por ejemplo, en su dimensión de mediadores pedagógico-políticos) para que pueda operarse la socialización y la integración política de los sujetos.

\section{LOS DISCURSOS POLÍTICOS DE LA LECTURA}

Es en el plano de los lenguajes políticos (o corrientes intelectuales políticas) donde es posible ver más fácilmente tanto las salidas que históricamente se le han dado a la lectura y a la escritura, como las prácticas lecturales y escriturales asociadas con el poder y el orden políticos. Por eso es necesario detenerse, al menos por un momento, en reconocerlos. Para ello debe advertirse que los Discursos Políticos sobre la Lectura son producto de los diversos lenguajes políticos; esto es, según Colom González, ${ }^{3}$ de aquella sedimentación e institucionalización de conceptos y categorías propios de la discusión política (con sus fuentes, posibles influencias y efectos), que se desenvuelven en un contexto constituido por el lenguaje como un todo, y que son portadores de sentidos históricamente construidos y ubicables. Por lo tanto, de la misma manera en que los grandes discursos políticos pueden establecer direccionamientos y modelos específicos de formación ciudadana, puede decirse que también le dan un

3 Francisco Colom González. La "cultura” y los lenguajes políticos de la modernidad. En Colom González, Francisco: Razones de identidad. Barcelona : Anthropos, 1998; p.66 
lugar particular a la lectura y a la escritura dentro de esos ideales y modelos. ${ }^{4}$

Son, pues, muchas las razones que podríamos argüir para sustentar la necesidad de revisar los discursos políticos sobre la lectura, pero en este trabajo queremos presentar dos de carácter central. La primera, se refiere a que (en tanto prácticas de orden cultural, social, educativo y político) la lectura y la escritura han exigido o se han acompañado de un cierto entramado discursivo que las justifica, las organiza y las informa como área o campo de desempeño de muchas disciplinas. Esto se hace especialmente evidente cuando se las ve atadas a la animación sociocultural (ASC) y sus responsabilidades educativas, sociales y culturales. De hecho, en su relación con la ASC, entran a participar de una tradición discursiva específica, vinculada con un conjunto disciplinario de conceptos, hipótesis, teorías y paradigmas que constituyen diversas concepciones del mundo.

4 Para el caso de Medellín, por ejemplo, se cree que en las propuestas de formación ciudadana que emergen en la dinámica de los últimos diez años, subyacen lógicas que construyen, deconstruyen y reconstruyen el lugar de la lectura y la escritura dentro del ámbito de la formación de la ciudadanía. En esas lógicas, para ser un poco más atrevidos, podría verse la existencia de un tejido discursivo común en el que se engarzan todas las tentativas políticas de modernización de la sociedad colombiana del siglo Xx. En efecto, parece que en cada propuesta de formación ciudadana hecha en este periodo existen iniciativas más o menos explícitas y comunes (a pesar de las grandes diferencias ideológicas que tienen entre sí, en otros campos) dirigidas a la inclusión de la lectura y la escritura. Ese hipotético tejido discursivo común y continuo sobre la lectura, se extendería desde las tempranas tentativas de "culturización" de los primeros años de la década de los noventa (dadas bajo las banderas de renovación de la relación de los ciudadanos con la ciudad, bajo la bandera de "ciudad educadora"), hasta el momento actual. Para ver una aplicación de esta hipótesis, remítase a la investigación desarrollada como Tesis de Maestría:

Didier Álvarez Zapata. Exploración de las relaciones entre lectura, formación ciudadana y cultura política: Una aplicación a las propuestas de formación ciudadana de la Escuela de Animación Juvenil (Medellín). Medellín : Universidad de Antioquia, 2003. 
La segunda razón se refiere a un orden mucho más acotado y práctico; es decir, tiene que ver con las necesidades discursivas de un sector de los animadores socioculturales (que trabaja en promoción y animación a la lectura), y que se ve impelido, con cada vez mayor fuerza, a tener que dar cuenta de sus prácticas. Y para ello debe hacerlo discursivamente.

Así pues, en este trabajo consideramos que los discursos políticos construidos en cualquier época sobre la lectura y la escritura, reflejan y moldean, simultáneamente, los imaginarios, los sentidos y las intencionalidades característicos de esa época. Podría hablarse, en consecuencia, de la existencia de Discursos Políticos sobre la Lectura y la Escritura que configuran las dimensiones sociales, educativas, culturales y económicas del momento histórico en que se producen y lanzan sus efectos al futuro. En particular, podría decirse que tales discursos acompañan, justifican y sustentan, ideológicamente, la integración de la lectura como medio y vehículo en los procesos de formación ciudadana.

Así, en el panorama de los discursos que sobre la lectura se han tejido, pueden verse específicamente operando, tres discursos: el discurso funcionalista liberal, el discurso republicano y el discurso crítico emancipatorio. Exploremos cada uno de ellos.

\section{EL LENGUAJE FUNCIONALISTA LIBERAL DE LA LECTURA Y LA ESCRITURA}

En este lenguaje, en términos generales, leer se representa como un dispositivo fundamental de la socialización política entendida como la plena expresión de las libertades individuales, la racionalización y la diferenciación intersubjetivas. Por ello la lectura se concibe y promueve como una supuesta dadora de identidad individual, se mitifica como aventura intimista, y se promueve como "reino de la libertad absoluta". En particular, tal lenguaje percibe a la lectura y a la escritura como estrategias centrales para los propósitos (ideológicopolíticos, evidentemente) de transmitir e inculcar las actitudes, valores y prácticas propias de las sociedades modernas asentadas en la democracia liberal. 
Pero si la lectura se promueve como práctica de consumo, la escritura se mitifica como práctica de creación estética, reservada sólo a algunos sujetos especialmente dotados para ello. Sobre la lectura se ejerce, así, un control social y político más estrecho: la lectura para todos, la escritura para las élites ilustradas que tienen como tarea la reproducción misma del sistema. Por ello, esta visión o enfoque liberal individualista de la lectura deviene funcionalismo en tanto que su afán se agota, por lo común, en habilitar para la reproducción cultural y no tanto para la producción. El lector se representa no como un sujeto social sino como un individuo aislado, disuelto en un ejercicio estético de corte onanista, que consume lo que otros escriben dentro de las claves estéticas y de ciencia que la sociedad legitima como las válidas. En ello, valga decirlo, se quieren actualizar principios básicos del liberalismo5 como el pluralismo razonable, en tanto que a través de la lectura y la escritura los ciudadanos, supuestamente, proponen (escriben) y consumen (leen), en la arena pública, ideas y propuestas que se idealizan como productos de las múltiples doctrinas morales, religiosas y filosóficas, razonables todas, pero inconmensurables y conflictivas. Este pluralismo, valga decirlo, según la queja de muchos, ha devenido en pluralismo libertino. De hecho, la crítica más fuerte es que las personas hoy lean por leer, no dentro de las claves que lo llevan a hacerse un ciudadano normalizado por las vías de la lectura de "cosas serias", sino que la lectura se banaliza convirtiéndose en una práctica más de alienación. Por esta vía, se cultiva una subjetividad aislada y alienada: lectura vendida como acto privado pleno de alusiones a la libertad individual sin marco alguno, parto del fuero individual en el que "todo vale".

Se trata, pues, en buena parte, de edificar la imagen del lector como consumidor (y si es voraz, todavía mejor) de discursos e imágenes emblemáticas de su propia vida que es, al fin y al cabo, una vida repetida por muchos y que se nutre de ciertos slogans de rebeldía

5 Ricard Zapata-Barrero. Ciudadanía, democracia y pluralismo cultural: hacia un nuevo contrato social. Barcelona : Anthropos Editorial, 2001; p. 59 
dados a cuenta gotas. La lectura, así, se vuelve una supuesta marca de diferenciación social, que, no obstante, y después de todo, hace individuos funcionalmente iguales: los lectores del bestseller, los lectores del tema de moda, los lectores del autor de ocasión.

El reconocido investigador social, Ezequiel Ander-Egg, dirige certeramente su crítica al lugar funcional de la lectura dentro del sistema liberal capitalista, al verla atada a la frenética pulsión por la diversión masificada que no hace otra cosa que atar a las personas a nuevas formas de control social del tiempo libre, a través del consumo cultural (y entre esto, a través de la lectura). En efecto, Ander-Egg, permite ver cómo el capitalismo de corte democrático liberal:

[...] ha transformado el tiempo libre en tiempo de consumo [...] Un tiempo que pretende ser libre, pero que no lo es. Es cierto que algunos dedican ese tiempo a leer, a pintar, a escuchar música, a gozar de la naturaleza, pero ello no es la tónica general. En estos casos habría que preguntarse [incluso] qué leen, qué música escuchan, etcétera, porque una actividad no es en sí misma una forma que ayuda al propio desarrollo. Algo tan 'inocente' como los comics o historietas, también son medios para influir ideológicamente en quienes se dedican a su lectura. ${ }^{6}$

En particular, puede decirse que el lenguaje funcional liberal de la lectura tiene tres principales derivaciones o vertientes discursivas que, en palabras de Freire, serían el "enfoque utilitario de la lectura", el "enfoque desarrollista cognitivo de la lectura" y el "enfoque romántico de la lectura".

La primera de estas vertientes (enfoque utilitario de la lectura), tendría como principal objetivo "formar lectores que cumplan con los requisitos básicos de la sociedad contemporánea" ${ }^{7}$ En efecto, según Freire, este enfoque hace énfasis en el aprendizaje mecánico de la lectura,

6 Ezequiel Ander Egg. "Metodología y práctica de la animación sociocultural”. Buenos Aires : Humanitas, 1984; p. 90.

7 Paulo Freire. op. cit.; p. 148. 
[...]sacrificando el análisis crítico del orden social y político que genera en primera instancia la necesidad de leer. Esta postura ha provocado el desarrollo de 'personas alfabetizadas funcionalmente', acicaladas básicamente para satisfacer los requisitos de nuestra cada vez más compleja sociedad tecnológica. ${ }^{8}$

Henry Giroux, por su parte, también señala las características básicas de esta vertiente, al decir que:

En el marco de esta perspectiva, la alfabetización está orientada a convertir a los adultos en trabajadores y ciudadanos más productivos dentro de una sociedad determinada. A pesar del atractivo del progreso económico, la alfabetización funcional reduce el concepto de alfabetización y pedagogía en que se inserta a las exigencias pragmáticas del capital; consecuentemente, las concepciones críticas de pensamiento, cultura y poder desaparecen bajo los imperativos del proceso laboral y la necesidad de acumular capital. 9

Un ejemplo de la manera "oficial" que bajo este enfoque utilitario representa a la lectura es el discurso de la UNESCO frente a la alfabetización. Nótese el afán de hacer aparecer a la lectura y la escritura como prácticas fundamentalmente dirigidas a integrar funcionalmente a las personas a un sistema capitalista puesto ya en una crisis de expansión y globalización de mercados:

El proceso mismo de aprendizaje de la lectoescritura debe convertirse en una oportunidad para adquirir información que pueda ser utilizada inmediatamente para mejorar los niveles de vida; la lectura y la escritura no deben llevar tan solo a un saber general elemental, sino a una preparación para el trabajo; a una mayor productividad, mayor participación en la vida civil y mejor comprensión del mundo que nos rodea, abriendo finalmente el camino al conocimiento humano básico. ${ }^{10}$

8 Ibid; p. 148.

9 Henry Giroux. Teoría y resistencia. Citado en: Ibid; p. 149.

10 UNESCO. Informe UNESCO 1976. Citado por: María Cristina Martínez. "El discurso escrito, base fundamental de la educación y la polifonía del discurso pedagógico", en: Entre la lectura y la escritura : hacia la producción interactiva de los sentidos. Bogotá : Cooperativa Editorial Magisterio, 1997. p. 133 
La segunda de estas vertientes (enfoque desarrollista cognitivo de la lectura), según Freire le "da importancia a la construcción de significados, por lo cual los lectores llegan a una interacción dialéctica entre ellos mismos y el mundo objetivo". "11 Pero el modelo

[...] evita criticar las concepciones académicas y utilitarias y no logra analizar el contenido de lo que se lee y si bien se destaca un proceso que permite que los estudiantes analicen y critiquen cuestiones que surgen en el texto con un nivel de complejidad creciente $[. .$.$] ignora el$ patrimonio cultural de los estudiantes -es decir, su experiencia vital, su historia y su lenguaje-, rara vez puede emprender una reflexión crítica profunda respecto de su propia experiencia práctica y de los fines que los mueven $[\ldots]^{12}$

La tercera de estas vertientes (enfoque romántico de la lectura), según palabras de Freire,

[...]destaca enormemente lo afectivo y concibe la lectura como la realización del yo y una experiencia jubilosa [este enfoque] no llega a concebir la problemática de los conflictos de clase o las desigualdades de género o raza. Más aún, el modelo romántico ignora totalmente el patrimonio cultural de los grupos sometidos y proclama que todo el mundo disfruta del mismo acceso a la lectura, o que la lectura es parte del patrimonio cultural de todo el mundo [...] el modelo romántico tiende a reproducir el patrimonio cultural de la clase dominante, al cual está íntimamente ligada la lectura. ${ }^{13}$

Precisamente con base en esta última idea, el enfoque romántico tiende a traslaparse y hasta confundirse estratégicamente con el lenguaje republicano de la lectura, que a continuación abordamos.

11 Podría decirse que esta perspectiva encuentra resolución contemporánea en las corrientes psicolingüísticas contemporáneas que, no obstante, empiezan a cuestionarse al respecto de las críticas de alejamiento de los móviles sociales y políticos de la lectura y la escritura. Buen ejemplo de ello son las últimas obras de autores como Frank Smith, "De cómo la educación le apostó al caballo equivocado"; Emilia Ferreiro, Delia Lerner .

12 Freire, op. cit.; p. 149.

13 Ibid; pp. 149-150. 


\section{EL LENGUAJE REPUBLICANO DE LA LECTURA}

En esta visión hay un fuerte énfasis en las relaciones entre los cánones clásicos de la lectura (originados y promovidos hegemónicamente por la sociedad mayor) y la pertenencia del sujeto a la comunidad y a la tradición. La subjetividad se construye en el ámbito de unos referentes comunitarios de largo alcance histórico y cultural que moldean al sujeto como perteneciente a una comunidad, con lo que se pretende que ese sujeto, primero que todo, se gobierne a sí mismo. En este sentido, la lectura se promueve como virtud pública: práctica ejemplar y emulable; un deber ciudadano dador de sentido; un bien público que ayuda a construir la ciudadanía considerada como auténtica naturaleza o virtud. La escritura, por su parte, se vuelve fuente de unificación que se opone a la diáspora cultural individualista de los sujetos que auspicia el liberalismo individualista. Escribir es narrar y narrarse dentro de un marco de largo aliento que hunde sus raíces en el mito y se extiende a un futuro prometido. Y escribir es enseñar, guiar, una práctica de magisterio.

En este enfoque la lectura se representa como la práctica educativa por excelencia, desde un supuesto retorno al humanismo clásico, y a través del cual la palabra escrita se vuelve totem. Por esta vía, el lenguaje republicano de la lectura, se traslapa con los discursos conservadores y románticos de la cultura y la educación. Según Jorge Larrosa, al evocar un tiempo ya ido en el que las cosas funcionaban con fortuna para la lectura dentro de un modelo societal humanista, (nosotros diríamos conservador y romántico),

En la lectura, el lector establecía una relación con el tiempo de la tradición y la cultura. Por eso la educación humanística, la educación entendida como lectura, implicaba una temporalidad diferente de la temporalidad de la vida [...]La dimensión temporal en la que la educación tenía sentido no era el tiempo biológico e individual de una vida particular, sino el tiempo histórico y colectivo de la cultura. Y eso porque el libro era, fundamentalmente, un relato, es decir, un traer al presente, un mantener lo dicho en el tiempo para que fuera infinitamente repetido y renovado $[. .$.$] y, en esa relación con la palabra, el lector se$ 
formaba a sí mismo. Por eso la experiencia de la lectura estaba ligada a la constitución de la memoria del lector. ${ }^{14}$

En este marco, la lectura de un canon de lecturas públicamente validado por la acción cultural y político educativa de las élites, antes que diferenciar, unifica, aproxima a las personas al origen mismo del grupo social al que pertenece. En efecto, hay en este enfoque el afán de "construir" y promover un cierto repertorio de lectura en el que se refleje la tradición, la igualdad en el origen (normalmente mítico) y un destino común (normalmente revelado). Leer se vuelve, al igual que en el liberalismo (... pero por otros caminos ideológico-políticos distintos), tremendamente funcionalista.

Por este camino y en tanto que virtud pública, la lectura se hace herramienta de construcción de una cierta ciudadanía adosada y respetuosa de la tradición, referida a un súmmun de ideas, representaciones y sentidos de la vida y el hombre, muy bien recogidas y promovidas en el canon.

Pero en general en el modelo republicano se necesita participar con intensidad en la vida política y para ello hay que estar "informado" y "formado", para lo cual la lectura y la escritura se hacen herramientas centrales. Éste es el más común de los discursos, que puede verse en muchos pensadores y personajes vinculados directamente con la esfera de la ideas republicanas, como por ejemplo, en George Ticknor $^{15}$ y sus proclamas como impulsor de la primera biblioteca pública "como tal" en Estados Unidos de América (Boston, 1854). Ticknor afirmaba que era indispensable desarrollar los medios de información y motivar a leer al mayor número de personas para que supieran de las cuestiones que los afectaban a ellos mismos y al orden social; sobre estos hechos debían tomarse continuamente decisiones,

14 Jorge Larrosa. La experiencia de la lectura : estudio sobre literatura y formación. Barcelona : Alertes, 1998; pp. 433-434

15 Destacado hispanista estadunidense, autor, por cierto, de la primera historia de la literatura española en sentido moderno. (1791 - 1871). Sus ideas son citadas por Hipólito Escolar Sobrino, en el libro "Historia de las bibliotecas". 
lo que exigía, para poder enfrentarlos del "conocimiento que aleja de la ignorancia”.

\section{EL LENGUAJE CRÍTICO ${ }^{16}$ EMANCIPATORIO DE LA LECTURA}

Este lenguaje está enraizado, históricamente, en los trabajos de teoría política de autores como Gramsci, Bakhtin y Volosinov. Y, más contemporáneamente, en los de investigadores de la cultura y la pedagogía como Giroux, Flecha, Colom, Macedo. Y, sobre todo, en los trabajos de diseño y aplicación de la alfabetización para la emancipación propuestos por Paulo Freire. Debe decirse que, en lo que respecta a sus relaciones con la pedagogía, el lenguaje crítico de la lectura se vincula, a través de la pedagogía crítica, con la Escuela de Frankfurt y su teoría crítica.

En general, puede decirse que el discurso crítico de la alfabetización, enfoca como centro de la acción alfabetizadora (del leer y el escribir...) a la babilitación política. Tal cual lo permite ver Henry Giroux al comentar las ideas de Antonio Gramsci:

Gramsci, verdadero maestro de la dialéctica, consideraba la alfabetización como concepto y práctica social, como vinculada históricamente, por un lado, a las configuraciones del conocimiento y el poder, y por el otro lado, a la lucha política y cultural en torno al lenguaje y la experiencia. Para Gramsci, la alfabetización era un argumento de doble filo: podía esgrimirla tanto con el propósito de lograr la habilitación individual y social, como para perpetuar las relaciones de opresión y dominación

16 En este trabajo entendemos que bajo el calificativo de "lenguaje político crítico" se pueden arropar las comprensiones que de la sociedad y del hombre contemporáneos hacen, desde contextos diversos, la Animación Sociocultural, la Pedagogía Social y la Educación Popular, entendidas como iniciativas de intervención emancipatorias. 
[...] como ideología, la alfabetización debía construirse como una construcción social siempre implícita en la organización de nuestra visión histórica, presente y futura [...] en otras palabras, en tanto construcción radical, la alfabetización debía estar enraizada en un espíritu crítico y un proyecto de posibilidad que capacitara a las personas para participar en la comprensión y la transformación de su sociedad. En tanto control de habilidades específicas y formas particulares de conocimiento, la alfabetización tenía que convertirse en una precondición para la emancipación social y cultural. ${ }^{17}$

Así pues, en síntesis, en esta visión se les otorga un especial papel a la lectura y a la escritura al cosiderárseles prácticas de emancipación; es decir, a la habilitación política de las personas a partir de la recuperación de su memoria y de su voz históricas. Por este camino, leer la realidad no es más que construir el sentido del mundo por medio de la recepción, la asimilación y la crítica de un cierto discurso ya construido por otros en otros momentos, quizás con otras necesidades. Esto, obviamente, nos vincula con la idea de cultura como construcción de sentido, y nos lleva a pensar que la lectura de la realidad lo que hace es permitir la co-construcción, asimilación y reactualización de estrategias ya existentes de acción social y política. Esto desemboca en un mar de preguntas dirigidas a entender las profundas relaciones entre la lectura como acto de significación, y la cultura como elemento diferenciador de la presencia pública de los sujetos (ciudadanos).

Se trata de permitir la asunción de la ciudadanía como un acto de cuestionamiento de las hegemonías que han determinado un orden social injusto y excluyente. Leer y escribir son, en consecuencia, prácticas para participar en el impulso hacia la inclusión social y política de las personas, y una facilitación para el autogobierno. "La alfabetización es para Freire, un proyecto político por el cual los hombres y las mujeres sostienen su derecho y su responsabilidad no sólo a leer, comprender y transformar sus propias experiencias, sino

17 Henry Giroux. Op. Cit. pp. 25-26. 
también a reconstituir su relación con la sociedad toda" ${ }^{18}$. Desde esta perspectiva, la alfabetización ha de volverse un intercambio dialógico en el que hay de por medio un intensa negociación cultural de significados donde la oralidad (hablar-escuchar) se vincula profundamente con la escritura y la lectura.

Por otra parte, las negociaciones culturales en las que se sustenta el ser ciudadanos, exigen, a su vez, una cierta y determinada elección de los contenidos culturales que puedan ser usados compartidamente por las personas. La pregunta que surge ante esto, es si es posible hablar de una activa y auténtica democracia radical (dirigida a la toma de conciencia, hacia el empoderamiento, hacia el autorreconocimiento y la autovaloración de las personas) sin la posibilidad de acceder autónomamente (a través de competencias de lectura y escritura formadas y activas) a una información que pueda ayudar a autorreconocer y satisfacer las necesidades de información que las personas tienen frente al mundo social, cultural y político. Dicho de otra manera, los esquemas de dependencia y heteronomía de la sociedad mayor, del mundo adulto ilustrado, ${ }^{19}$ al cual deben integrarse las personas, pueden verse fortalecidos en virtud de una escena pública que no cuestione, de

18 Ibid; p. 31.

19 El concepto de mundo adulto ilustrado, lo utilizamos para representar aquella expresión de la sociedad mayor que, con un cierto discurso estructurado en la formación académica y científica, sirve para integrar al joven al mundo adulto, por medio de la "imposición" pedagógica de ciertas explicaciones del mundo, normalmente de corte "científico oficial" y que se difunden, principalmente, por la Escuela y los medios masivos de comunicación. Es en esto donde se actualiza y perpetua, la idea moderna de la ciencia como dadora de sentido y de construcción de la imagen del mundo que debe ser inculcada principalmente en los niños y jóvenes. Por cierto, debe decirse que ese substrato ideológico-científico, sigue radicado en la escrituralidad.

Sobre este tema, véase el libro.

José Sanmartín E. Los nuevos redentores : reflexiones sobre la ingeniería genética, la sociobiología y el mundo feliz que nos prometen. Barcelona : Editorial Anthropos, 1994. 
manera fundada, los mecanismos por los cuales se establecen esos esquemas (es decir, la lectura y la escritura, lo que se lee y escribe). Esto es, una escena pública que no critica los procesos de perpetuación de la exclusión cultural y la pérdida de la memoria colectiva que toman lugar por las vías de la negación del leer y la elitización del escribir.

En efecto, no creemos equivocarnos al decir que ningún otro lenguaje político como el crítico, ${ }^{20}$ resalta tanto las iniciativas dirigidas a considerar el lenguaje (hablar, escuchar leer y escribir) como un territorio de disputas y de arduas negociaciones culturales del poder y de la acción política; es decir, de la formación del ciudadano. En las propuestas de alfabetización crítica, es muy claro el afán por recuperar la palabra y la voz de las personas vinculadas a los procesos de educación para la emancipación:

En primer lugar está la insistencia en la oralidad como el principal espacio de construcción textual desde el cual se puede dar cuenta del sí mismo en el mundo, y como medio central para promover la recuperación de los saberes previos y las sensibilidades de las personas. Esta preferencia y elección explícita por el modo de producción y consumo textual oral, tiene, de hecho, grandes implicaciones y efectos en la sustentabilidad de un modelo pedagógico crítico, en tanto que la relación de lo oral con los otros modos de producción y consumo textual, deja de ser anacrónica. Esa situación favorece el planteamiento para dar respuestas adecuadas a las tensiones que toda América Latina sufre entre la persistencia histórica de la oralidad como principal medio de relación social (lo que algunos, desdenosamente, llaman el lastre oralista, y que supuestamente nos

20 En este trabajo entendemos que bajo el calificativo de "lenguaje político crítico" se pueden arropar las comprensiones que de la sociedad y del hombre contemporáneos hacen, desde contextos diversos, la Animación Sociocultural, la Pedagogía Social y la Educación Popular, entendidas como iniciativas de intervención emancipatorias. 
mantiene en sociedades premodernas), y el ímpetu alucinante de la audiovisualidad y la multimedialidad. ${ }^{21}$

Esas respuestas estarían más en la dirección de ayudar a confrontar (y por tanto, a desarrollar) un uso más complementado y situado histórica y culturalmente de la oralidad, en relación con el leer y el escribir; esto es, un uso que dé cuenta de la relación de co-construcción (correlatos) de la oralidad con lo escrito, lo audiovisual y lo multimedial, en tanto que diversos Modos de Producción y Consumo Textual ${ }^{22}$ que favorecen la consolidación de su memoria, de sus discursos, de sus subjetividades, identidades colectivas y retos de época.

En segundo lugar, la concepción que de la lectura y la escritura se tiene en este lenguaje, responde a un sentido amplio del leer; es decir, a un proceso de construcción del sentido de las cosas del mundo y de los fenómenos sociales. De hecho, es frecuente el uso didáctico de la expresión "leer" como una forma de referirse al proceso por medio del cual las personas se dedican a observar, conocer y analizar

21 Resulta interesante recordar que un punto central en el debate actual de la lectura, es el referido a las tensiones que se presentan entre oralidad, escrituralidad y multimedialidad, que en el contexto de América Latina resultan ser neurálgicas al momento de entender las relaciones entre lectura, cultura y política. En efecto, nuestra continente es frecuentemente representado como un espacio cultural rico en oralidad y pobre en escrituralidad, en el que las nuevas tecnologías informáticas y massmediáticas resultan ser apropiadas de maneras inéditas o, que al menos, traen nuevos retos de orden cultural y político. De hecho, para algunos investigadores (entre los que hay que resaltar a Emilia Ferreiro y a Jesús Martín Barbero), los "saltos" culturales que debe dar América Latina tras el uso globalizador de las nuevas tecnologías, retan profundamente las estrategias de acción cultural cimentadas en una oralidad activa y les exigen a las personas rehacer la idea de la palabra, de la lectura y de la escritura. De hecho, intensos usos comunicativos de la palabra en una oralidad de este tipo (tradicional y vinculante: de primer nivel), se ven hoy replicados por otros usos de la palabra en una oralidad de segundo nivel: la oralidad autoritaria de la escuela y la oralidad trunca, de la radio y la televisión, por ejemplo.

22 Al respecto del Modo de Producción y Consumo Textual, véase:

Didier Álvarez Zapata,. "Del modo de leer como modo de producción y consumo textual: ideas fundamentales de una categoría en construcción”, en Revista Educación y Pedagogía. Universidad de Antioquia. Medellín. (Ene. -Jun. 2002) 
un cierto fenómeno. En las propuestas de alfabetización crítica, las relaciones entre leer y el mundo son plenamente intencionadas, críticas y emancipatorias. De tal forma, se lee y escribe para comprender y transformar el mundo. Por tanto, quien lee la palabra (oral y escrita) está leyendo también el mundo para problematizarlo. En este sentido, la palabra escrita es el mundo contado por otros (con ciertas visiones, desde ciertos poderes) y también por quien lo lee, porque se vuelve un co-constructor de ese discurso. La idea de que la lectura es una acto de construcción de sentido en que se interactúa con el pensamiento de otro y un contexto, es una idea plenamente vigente en este lenguaje político. En esto hay que advertir que, por otra parte, "leer el mundo" es un acto comúnmente representado como accesible para todos, pero que requiere de una cierta "alfabetización” posible desde, principalmente, la lectura de la palabra; es decir, desde los acumulados históricos registrados (mediante la tradición oral vuelta memoria colectiva, o la palabra escrita vuelta libros, o la imagen vuelta signo que comunica y señala realidades) con los cuales cuenta la comunidad.

\section{ALGUNAS PALABRAS DE CIERRE}

No cabe duda que la lectura y la escritura tienen estrechos vínculos con las maneras en que el poder y el orden político se procesan. El problema es que hemos estado poco dispuestos y escasamente atentos a superar las visiones que las restringen a lo meramente instrumental y funcional. Pero debemos empezar por estudiar con responsabilidad, y a partir de programas de investigación viables pero ambiciosos, las formas y estrategias en que la lectura y la escritura se han "asimilado", y han sido retomadas y reconfiguradas en los diversos lenguajes políticos. En este trabajo hemos querido plantear algunas pistas e indicios que, a nuestro parecer, pueden resultar útiles tanto para esclarecer el asunto como para llenarlo de nuevas preguntas y oscuridades, en un movimiento dialéctico retador y excitante en grado sumo. 


\section{BIBLIOGRAFÍA}

ÁLVAREZ Zapata, Didier. "Del modo de leer como modo de producción y consumo textual: ideas fundamentales de una categoría en construcción", en Revista Educación y Pedagogía, Universidad de Antioquia. Medellín. (Ene. -Jun. 2002).

- - . Exploración de las relaciones entre lectura, formación ciudadana y cultura política : Una aplicación a las propuestas de formación ciudadana de la Escuela de Animación Juvenil (Medellín). Medellín : Universidad de Antioquia, 2003. (Tesis de Maestría. Universidad de Antioquia. Instituto de Estudios Políticos).

ANDER Egg, Ezequiel. Metodología y práctica de la animación sociocultural, Buenos Aires : Humanitas, 1984.

COLOM González, Francisco. La "cultura" y los lenguajes políticos de la modernidad, en Razones de identidad. Barcelona : Anthropos, 1998; p. 66.

FREIRE, Paulo. "La alfabetización y la pedagogía crítica", en Freire, Paulo y Macedo, Donaldo. Alfabetización : lectura de la palabra y lectura de la realidad, Barcelona : Paidós, 1989.

LARROSA, Jorge. La experiencia de la lectura : estudio sobre literatura y formación. Barcelona : Alertes, 1998.

MARTÍNEZ, María Cristina. "El discurso escrito, base fundamental de la educación y la polifonía del discurso pedagógico!, en: Entre la lectura y la escritura : hacia la producción interactiva de los sentidos. Bogotá : Cooperativa Editorial Magisterio, 1997.

PETRUCCI, Armando. "Leer por leer: un porvenir para la lectura", en: Historia de la lectura en el mundo occidental. Madrid : Taurus, 1998

ZAPATA-BARRERO, Ricard. Ciudadanía, democracia y pluralismo cultural: hacia un nuevo contrato social. Barcelona : Editorial Anthropos, 2001.

ZILBERMAN, Regina. "Sociedade e democratizaçao da leitura", en: Heitor Barzotto, Valdir, comp. Estado de leitura. Campinas, SP :Mercado de Letras : Associaçao de Leitura do Brasil, 1999, pp. 31-46. 


\title{
Lector: ser o no ser
}

\author{
NOÉ JITRIK
}

-mpecemos por decir que ninguna pregunta que incluya el verbo
ser" en ninguna de sus formas, más allá de su ser de verbo, tiene
-i puede tener respuesta no sólo porque nunca la ha tenido sino porque la entidad a la que remite, el ser o sea la esencia, es una postulación, una manera de decir, no algo, no una cosa. De modo que ser lector o ser persona, hoy o en cualquier momento, es un imposible como entidad pero esto no quiere decir que no puedan entenderse tanto las aproximaciones a su facticidad como la oscuridad de su definición o, más modestamente, de su aceptación.

En esa penumbra semántica, creemos saber de qué se trata cuando mencionamos la palabra persona o la palabra lector o procedemos a una designación en tal sentido o le atribuimos tal carácter a alguien: la designación -o sea el ámbito de la lingüística- desplaza en ese caso a la definición -o sea el ámbito de la pragmática-y, por supuesto, al concepto, o sea el ámbito de la gnoseología y de ahí de la ontología, que es donde el "ser" parece estar albergado y protegido, donde es. Estos sucesivos desplazamientos diluyen y perturban pero al mismo tiempo permiten vivir, es "como si" supiéramos qué es ser persona y, por añadidura y para lo que importa ahora, qué es ser "lector". Y, por añadidura, podríamos decir que con ese "como si" de la persona se manejan políticos, psicólogos, teólogos, médicos y educadores; con el "como si” del lector sociólogos, críticos, editores, publicistas y semiólogos.

El lector, entonces, desde este punto de vista no es, lo que en este momento no quiere decir mucho, pero existe y con esa existencia, problemática desde luego, nos tenemos que arreglar: ¿cómo es que existe? es la pregunta que surge de inmediato. Para quienes se manejan cómodamente en el "como si", del mismo modo que para los políticos las personas -en listas gigantescas llamadas "padrones", que salen de su inmovilidad para votar cuando no para protestar o pedir-, 
el lector existe antes, durante y después de su relación con el objeto con el que está relacionado para existir y con independencia de ese objeto; si se le atribuye existencia, en tal caso, sólo porque el objeto existe, resulta que es un a priori en la existencia de los textos que motivan en realidad su existencia; siguiendo este razonamiento, los textos que lo hacen lector podrían desaparecer pero él, como lector, seguiría existiendo pese a que por el hecho de la desaparición de su objeto se convierte en los hechos en virtual o, aun, en memoria de lo que llegó a ser, o sea lector, cuando se encontraba frente a un texto y lo leía: nació una vez y nada lo destituye aunque no ejercite la condición que permitió su nacimiento; nació y se estableció como categoría y nada lo saca de su sitial. Para este razonamiento, esa instalación es monárquica, el lector es rey.

¿Cuáles son los atributos de su majestad? El primero y fundamental, casi el único, es el del respeto que se le debe: no hay que molestarlo ni juzgarlo, no hay que agredirlo, no hay que crearle dificultades, no hay que exigirle que responda a lo que le dio existencia; o sea, en suma, que no hay que exigirle que lea, no se le puede pedir, ni siquiera humildemente, que trate de comprender más allá de lo que aparece en la superficie de los textos. Esta idea de lector, por el contrario, no me merece el respeto que se le rinde en vastos ámbitos de la sociedad, nadie podría pensar, por el modo en que lo enuncio, que yo crea que un lector de verdad, a plena lectura, pueda ser ese irritable y trivial monarca. Podría decirse, en cambio, para zanjar la cuestión y responder a la pregunta, que es probable que ése, y sus prolongaciones, sea el atributo que le da forma al así llamado "lector de hoy" y no al que yo pienso que es un lector de verdad, tal vez un lector menos ideal de lo que se puede pensar y cuyos atributos o cualidades tendría que establecer.

En cuanto al presunto lector de hoy, al menos el predominante, un desarrollo analítico de tales atributos o cualidades podría dar lugar, consecuentemente, a una descripción ajustada de lo que es tan interesante lector y, a partir de ahí, permitiría, al menos en parte, comprender el estado de una cultura pues no hay duda de que la forma de la lectura en un momento determinado hace por sinécdoque un dibujo de la cultura en la que se ejecuta. Primera y provisoria conclusión: si el 
lector de hoy es ese irritable y trivial monarca, la cultura de hoy tiene el mismo carácter, es irritable y trivial.

Por otra parte, si la confluencia o articulación de esos atributos o cualidades resultó en esa forma que hoy es predominante podemos preguntarnos si en otro tiempo fue otra su forma predominante; por supuesto también tendríamos que preguntarnos si la cultura fue también otra en un tiempo que le fuera correlativo. Podríamos decir que sí, que hubo otro tipo de lectores si fuéramos nostálgicos, o decir que no, que lector y cultura tuvieron siempre la misma forma si eligiéramos el escepticismo. Y en esos puertos, el del sí y el del no, se podría cerrar la cuestión.

Pero más interesante es otra pregunta que se abre: ¿es desde ese presupuesto formal, puesto que hemos empleado la expresión "forma" del lector, que se puede abordar más ampliamente el tema del lector y el superior tema de la lectura? Se diría que este enfoque tiene cierto carácter fenomenológico y respetarlo o seguirlo puede sin duda dar algunos frutos o caracterizaciones útiles. Pero, limitándome a enunciarlo, pretendo apartarme de esta vía y volver a lo que está antes, a lo que inicia esta reflexión o sea a la imagen, para muchos tal vez sólo crítica y escéptica, de un "no ser" o un ser imposible del lector, compensada o sustituida por la de, al mismo tiempo, la existencia indudable del lector; quiero eludir, también, dicho sea entre paréntesis, el dramatismo, probable y muy narrativizado, de un existir apegado a la experiencia, tal como lo aconsejaba Macedonio Fernández; el filósofo argentino hablaba, con cierta sorna, de un "existidor", como de alguien que, poseído de la voluntad de existir, propugnara las condiciones superiores de la existencia, parafraseando preocupaciones preexistencialistas de Schopenhauer. En este desafiante marco, es el momento de decir que una vez que el lector cobra existencia gracias al comienzo de ese proceso relacional, o sea cuando echa una mirada sobre un conjunto escrito, que se denomina "lectura", y se deja crear como lector por el texto que lee, gravitan sobre la acción que comienza diversas fuerzas; las podemos llamar "condiciones" de lectura; algunas son previas y están en suspenso y en probable y constante reformulación, por añadido, por corrección, por olvido, por aprendizaje: es como si, cuando la lectura comienza, esas fuerzas 
fueran convocadas; otras actúan durante el acto, se diría que son inherentes al acto mismo.

¿Cuáles son las previas? Ante todo el saber de la lectura, o sea el conocimiento de los alcances de esa actividad, en apariencia obvia; luego, la disposición a aplicar ese saber en una circunstancia precisa, me refiero al contacto con un texto; también ciertas condiciones materiales para poder llevar a cabo ese acto-iluminación, ambiente, silencio- y, entre otras, la posibilidad o la capacidad de elegir el objeto sobre el que se realizará la lectura.

¿Y las otras? Son más difusas pero no por ello inertes, al contrario, son las que definen mejor el lector ideal al que aludí. En primer lugar, la dimensión del comprender, un comprender de lo que el texto entrega y al mismo tiempo del acto que se lleva a cabo; luego, la disposición a dejarse "tomar" tanto por el objeto legible, como expresión de una diferencia, como por la actividad lectora misma, en tanto diferencia; en tercer lugar, la autoconciencia de lo que se está haciendo cuando se lee -lo cual vendría a ser equivalente a la verificación del existir como lector-, junto con la conciencia de una adquisición indefinida e incesante y, por último, la que me parece la principal, la valentía de suspender provisoriamente todo el saber, menos el de la lectura, para entregarse al vértigo de lo diverso, entrar en ese territorio inermes y admitir que lo que vaya a ocurrir después implicará un no retorno a lo ya sabido y un ingreso a una condición nueva y diferente, tal vez superior, de saber.

Estas condiciones, por ser tales, enmarcan el acto de la lectura y, desplegadas, constituyen un abanico de posibilidades de epistemologizarla de modo tal que si leer suele ser considerado un obvio del modo de la civilización humana, una necesidad ineludible a satisfacer, pasa a ser así un objeto de conocimiento como cualquier otro, tan exigente de conocimiento como cualquier otro.

Pero una cosa es, siguiendo cierta metodología vagamente fenomenológica, un probable sistema de preguntas tendientes a conocer la lectura y otra al lector; la diferencia salta a la vista: no es sólo el abismo que media entre sujeto y objeto y los vasos comunicantes sino la diferencia de índole y de ámbito; de este modo, la lectura es, por empezar, una actividad, y como tal semiológica, y una práctica 
productora de sentido, y como tal semiótica, sometida a condiciones de producción y ejecutada según modalidades y métodos; el lector es sólo un agente en esa actividad y esa práctica o el ejecutante y, por lo tanto, depende de ella y hasta está subordinado a ella; para decirlo de una manera escandalosa, no hay lector sin lectura o, de otra manera, ratificando las primeras afirmaciones, si no hay práctica la agencia no tiene sentido y por fin, cerrando el razonamiento, el lector, que no era pero que existía, tampoco existe.

Ahora bien, las primeras precisiones acerca del lector de "hoy" fueron aproximativas y tributarias de consideraciones de orden general; así la idea de su majestad o de su existencia previa al acto de lectura. A partir de la oposición con la lectura quizá se pueda saber algo más acerca de su perfil. Quizá podría decirse, a la luz de los planteos procedentes, que su forma y cualidades están determinadas por el estado social de la lectura que, a su vez, adquiere su forma por el juego de las mencionadas condiciones, previas y posteriores. En ese sentido, podría decirse, en principio, que el "lector de hoy" es, en términos generales y mayoritarios, alguien que, respondiendo, porque no puede hacer otra cosa, por lo general sin advertirlo, a lo que llamamos "condiciones previas", omite, desconoce o desdeña las inherentes al acto de lectura, que serían las que, completando el acto, le darían su efectiva existencia de lector y sentido a la lectura. Por el contrario, quien fuera consciente de las condiciones previas y pudiera remodelarlas al responder a ellas pero, sobre todo, quien respondiera a las otras, en especial a lo que llamaba la "suspensión temporaria del saber", sería un lector ideal, que es posible que también sea el de hoy o, mejor dicho, un lector al cual la cultura debe tender porque implica una culminación, la de ser lector en un sentido pleno.

Pero tal vez no se quiere que respondamos a la pregunta desde esta perspectiva que es desde luego problemática y, en cambio, se nos quiera llevar, cuando nos la hacen, a un terreno ambiguamente sociológico, en el cual se encuentra a gusto la lógica de las encuestas acerca de cantidad y calidad de la lectura. Dicho de otro modo, que se nos quiera llevar a decir que el lector de hoy lee poco y mal, o mucho y mal, o no lee nada y es deseable que lea algo, o que hay algunos, los menos, que leen bien, poco o mucho, y todo eso, una u otra 
verificación, como síntoma de una sociedad que se desagrega o está a punto de perder lo único bueno que tenía, o sea una cultura que era valiosa porque residía en el libro que era, a su vez, el compendio de lo más excelso y elevado que había sido capaz de crear el ser humano; y, en esa perspectiva, que se nos quiera llevar a decir, cosa que no sólo es irrenunciable sino que es muy justa desde mi punto de vista, que los que leen bien, poco o mucho, son los últimos resistentes, los que siguen alimentando el fuego de la especie, de los cuales Aldous Huxley, en Un mundo feliz, propuso una inolvidable y acaso consoladora metáfora, la de un solo lector de un único libro, Shakespeare, como delegado escudo que detiene la negativa utopía del olvido y la barbarie tecnológica.

Es cierto que fuera de una mirada cuantitativa y sociológica, incluidos algunos ingredientes interpretativos de origen más o menos psicoanalítico, es difícil manejarse; sobre esa mirada descansan las políticas de lectura, cuando las hay, la pedagogía, la comunicación y los criterios editoriales, ya sea si se entiende que el lector es creado, insisto, por el texto, lo que no dejaría de ser también algo perverso en la medida en que sea dirigido por imposición, por censura o por canonización en función de objetivos políticos o filosóficos o comerciales, o bien que preexiste a la relación con los textos y, se supone, las editoriales, las academias, los premios, que posee un perfil bien determinado y, de ahí, cuáles son sus preferencias, necesidades o exigencias.

Mi propuesta va ciertamente en otra dirección e implica un empezar todo de nuevo, un volver a pensar en dos órdenes, uno crítico y acaso descriptivo acerca de la forma del lector de hoy, el otro propositivo, en el sentido de un cambio en la proporción, por crecimiento de la forma posible del lector ideal y decrecimiento de la forma del lector que se presume actual. No creo estar del todo preparado para semejante tarea, aunque creo estarlo para oponerme, tal vez sin demasiada crítica, a los criterios en curso o a los sobreentendidos establecidos, como, por ejemplo, la necesidad de trazar un perfil del lector actual a partir de esas socorridas negatividades que no faltan en ningún diccionario de lugares comunes. Porque, por comenzar, sostener que se puede trazar un perfil del lector tiene el grave inconveniente de que 
las excepciones y las contradicciones son tan numerosas que desvirtúan toda encuesta y toda conclusión.

Más valdría, en consecuencia, liberar una reflexión sobre la suerte de los tópicos que han ido surgiendo, con la esperanza de lograr una aproximación a lo que la pregunta significa. Y lo que la pregunta significa presupone lo que en otras palabras se ha señalado, o sea que el perfil del lector de hoy, o sea la forma del lector de hoy, es homólogo a la forma de la cultura de hoy; subsidiariamente, hay que decir que la forma del lector de hoy es homóloga a la de la lectura de hoy. Todo ello hace un entramado o una articulación de formas que se superponen y se significan en un telos que funciona como objetivo y como interpretante.

Este telos no es el de una mera toma de distancia crítica respecto de un perfil insatisfactorio de lector sino el de una preocupación mayor por lo que acecha a una cultura humanística que, imperfecta y todo, en formación, llena de contradicciones y de tentativas, era la garantía, no obstante, por lo menos de un deseo de identidad, en el orden individual, en el orden nacional, en suma en todos los órdenes.

La pregunta, entonces, pone en escena el riesgo que implican las desatadas potencias tecnológicas y económicas que con su previsible y verificable secuela de deshumanización tienden a cambiar el rostro de una civilización. La pregunta por el lector de hoy, por lo tanto, tiene un amplio telón de fondo que constituye un lugar al que se trata de llegar por este callejón en apariencia estrecho, y al mismo tiempo quiere entender su configuración y su significación.

Arrastrados por consideraciones generales y panorámicas, seducidos por sistemas deductivos, no terminamos de entender las gesticulaciones explicativas de la relación que puede haber entre los grandes movimientos de la sociedad y lo que nos pasa individualmente, estamos perplejos ante lo que se podría llamar el "cambio" y lo que produce en los modos de la cultura que todavía estimamos; y como nos debatimos en la alusión, el estilo oblicuo, el temor al vacío, nuestro modo de lectura corre la misma suerte y determina el modo, o si se quiere, el "ser" del lector o la existencia concreta del lector predominante hoy, ése que no quiere que un texto lo perturbe e intente arrastrarlo a un lejano lugar en el que el cambio que se anuncia para 
la civilización todavía no ha entrado ni tiene lugar. Un lugar semejante al que Huxley pensó para Un mundo feliz pero menos desesperado y mucho más solidario ante todo con los otros, ya lectores o todavía no lectores, y luego con los textos, depósitos de la diferencia, objetos de resistencia, vehículos todavía para entenderse en un mundo que tiende a no entenderse de ningún modo. 


\section{Los ponentes}

Con la finalidad de conocer un poco más sobre los autores que participaron en el Seminario de Lectura: pasado, presente y futuro, en este apartado encontrarás una breve biografía de su vida académica que de alguna manera se ve reflejada en su actividad profesional, la cual ha contribuido al fortalecimiento de la lectura.

\section{Filiberto Felipe Martínez Arellano}

Reconocido bibliotecólogo mexicano por sus contribuciones a la problemática de la organización del conocimiento; además, por una fructífera labor docente en la licenciatura y el postgrado. Aparte de impartir clases, dirigir y asesorar tesis, impulsó la reforma para la modernización del plan de estudios de la licenciatura en bibliotecología, y de igual manera la infraestructura del Colegio de bibliotecología de la Facultad de Filosofía y Letras de la UNAM durante su gestión como Coordinador del mismo. Está doctorado en Educación Superior y Bibliotecología en la Universidad Estatal de Nueva York en Búfalo y tiene Maestría en Bibliotecología por la UNAM. Es actualmente director del Centro Universitario de Investigaciones Bibliotecológicas, autor y coautor de varios libros y artículos publicados en revistas nacionales e internacionales. Presidió también la Asociación Mexicana de Bibliotecarios.

\section{Michèle Petit}

Antropóloga en el laboratorio «Dinámicas sociales y recomposición de los espacios» del Centro Nacional de Investigación Científica (CNRS) y de la Universidad de París. Titular de un doctorado de tercer ciclo en letras y ciencias humanas. Después de estudiar sociología y lenguas orientales, su formación intelectual se ve profundamente influida por el encuentro con el psicoanálisis y decide orientarse hacia 
investigaciones que no disocien lo social de los sujetos singulares que lo constituyen.

Desde 1992, concentra sus investigaciones en torno a la lectura y la relación con los libros y las bibliotecas, privilegiando los métodos cualitativos sobre cualesquiera otros. Conduce un estudio sobre la lectura en el medio rural y luego coordina una investigación referente a la contribución de las bibliotecas públicas en la lucha contra los procesos de exclusión y relegación, basándose en entrevistas con jóvenes que habitan en barrios desfavorecidos. Como una prolongación de estos trabajos, profundiza el análisis del rol de la lectura en la construcción del sí mismo, en particular en momentos de crisis de identidad. Actualmente, pone particular atención en los aspectos restauradores de la lectura.

Es autora de dos libros de ensayos y conferencias publicados en México por el Fondo de Cultura Económica, en la colección «Espacios para la lectura»: Nuevos acercamientos a los jóvenes y la lectura (traducido del francés por Rafael Segovia y Diana Luz Sánchez, 1999), y Lecturas: del espacio intimo al espacio público (traducido del francés por Miguel y Malou Paleo, y Diana Luz Sánchez, 2001).

\section{Juan Ros García}

Es catedrático de tiempo completo en la Universidad de Murcia (España), de la Facultad de Ciencias de la Documentación en el área de biblioteconomía y documentación, y doctor en filología románica; su línea de investigación está encaminada a la planificación de servicios de información y documentación, así como a las políticas de información.

Ha publicado diversos artículos y libros en donde se refleja su larga y experimentada preocupación didáctica por su especialización en lingüística documental, lo que ha producido un esfuerzo auténtico por dotar de epistemología a la disciplina y por contribuir a la mejor formación de estudiantes y profesionales. Ha presentado ponencias en eventos con carácter nacional e internacional y realizó tanto en la Universidad de La Habana como en la Universidad de Piura (Perú) dos estancias académicas. 


\section{Juan Domingo Argüelles}

Poeta, ensayista, crítico literario y editor. Estudió Lengua y Literatura Hispánicas en la Facultad de Filosofía y Letras de la UNAM. Actualmente se desempeña como director de Normatividad, Entrenamiento e Información en la Dirección General de Bibliotecas del Conaculta.

Ha publicado 12 libros de poesía y siete volúmenes de estudios y ensayos literarios, asimismo, ha preparado y prologado diversas antologías literarias de divulgación. Entre otros reconocimientos ha recibido el Premio Nacional de Poesía Efraín Huerta, el Premio de Ensayo Ramón López Velarde, el Premio Nacional de Literatura Gilberto Owen y el Premio Nacional de Poesía que otorga el estado de Aguascalientes.

Ha sido coordinador de publicaciones periódicas de la Dirección General de Publicaciones del Conaculta y Coordinador Ejecutivo del Programa Cultural Tierra Adentro y subdirector de la revista del mismo nombre.

\section{Elsa Margarita Ramírez Leyva}

Investigadora del Centro Universitario de Investigaciones Bibliotecológicas y docente de la licenciatura y postgrado de Bibliotecología y Estudios de la Información que se imparte en la Facultad de Filosofía y Letras de la UNAM. Ha estudiado la influencia del medio impreso en la occidentalización de México y la gestación de un sistema social de comunicación escrita. Este estudio le despertó la inquietud por conocer los efectos de la tecnología electrónica, como una nueva occidentalización.

\section{Daniel Goldin}

Su formación humanista nos remite a un editor sui generis, de los pocos que están ocupados en hacer una selección cuidadosa de sus ediciones, y en promover la lectura y formar lectores, y mediadores. Su trabajo se ha enfocado a la población infantil y juvenil. Además fue el iniciador de una serie de temas sobre reflexión e investigación del libro, la lectura y los lectores, que se vinculó con la serie editada por el Fondo de Cultura Económica. 


\section{Christine Garbe}

Profesora en germanística (literatura y didáctica) por la Facultad de Pedagogía y en la Facultad de Ciencias Culturales Aplicadas, y profesora de Lenguaje y Comunicación de la Universidad de Lüneburg en Alemania.

De 1985 a 1990 ofreció docencia en forma independiente para la formación de adultos con (énfasis en proyectos de formación para la mujer) y fue profesora en la FU (Universidad Libre, de Berlín). En 1991 obtuvo su doctorado sobre Jean-Jacques Rousseau.

Ha desarrollado diversos proyectos de investigación entre los que se destacan: Estudio de casos biográficos del uso de medios y de la lectura (de 1996 a 1998) y el Proyecto de investigación de la DFG (Sociedad Científica Alemana) Comportamiento de lectura en la adolescencia según el género (desde septiembre de 1998).

Se propone realizar un análisis de las diferencias propias del género que han aparecido en los últimos años en los estudios sobre el uso de medios, por lo que toca a sus causas, manifestaciones y consecuencias didácticas.

\section{Didier Álvarez Zapata}

Bibliotecólogo de la Escuela Interamericana de Bibliotecología de la Universidad de Antioquia, especialista en Animación Sociocultural y Pedagogía Social de la Fundación Universitaria Luis Amigó, candidato a Maestro en Ciencia Política del Instituto de Estudios Políticos de la Universidad de Antioquia, profesor de tiempo completo en la Escuela Interamericana de Bibliotecología de la Universidad de Antioquia, donde trabaja en las cátedras de sistemas de información, teoría de la lectura y animación a la lectura, es coordinador de la línea de promoción social de la lectura en los semilleros de investigación científica de la Escuela.

Su principal foco de interés académico se ha dirigido hacia la comprensión de las relaciones entre ciudadanía, lectura y bibliotecas. En este campo ha investigado y publicado en revistas nacionales e internacionales, y presentado ponencias en eventos de carácter nacional e internacional. Es actualmente presidente del capítulo local de Asociación Colombiana de Lectura y Escritura Asolectura. 
Como docente ha estado trabajando en el desarrollo de propuestas de mejoramiento para la lectura y la escritura en los alumnos del pregrado en bibliotecología, a través de pensamiento gráfico y las llamadas tecnologías de la mente.

\section{Noé Jitrik}

Prestigiado escritor, crítico literario, académico argentino, reconocido en el ámbito internacional por la calidad de su trabajo. Su obra le ha merecido galardones, como el de Chevallier des Arts et Des Lettres otorgado por el gobierno de Francia, y el Premio Xavier Villaurrutia, México, 1981. En el 2001, en Puebla, México, se celebró un Congreso Internacional de homenaje a Noé Jitrik que tuvo como motivo el Doctorado Honoris Causa, otorgado por la Benemérita Universidad Autónoma de Puebla a este incansable maestro. Actualmente es director e investigador del Instituto de Literatura Hispanoamericana en la Facultad de Filosofía y Letras de la Universidad de Buenos Aires y dirige una monumental obra, la Historia Crítica de la Literatura Argentina, que aparecerá en doce tomos publicada por Editorial Sudamericana.

El doctor Jitrik vivió la mayor parte de su vida en Buenos Aires, y algunos años en Europa y en México, donde estuvo exiliado entre 1974 y 1987. Es autor de numerosos ensayos sobre literatura e historia, crítica literaria, teoría y narraciones, cuentos y novelas y ha sido profesor e investigador en universidades de Buenos Aires, México y Francia. 

Lectura: pasado, presente y futuro. La edición consta de 500 ejemplares. Coordinación editorial, Ignacio Rodríguez Sánchez. Formación editorial, Carlos Ceballos Sosa. Revisión especializada Francisco Xavier González y Ortiz. Centro Universitario de Investigaciones Bibliotecológicas/ UNAM. Fue impreso en papel cultural ahuesado de 90 gr. en Desarrollo Gráfico Editorial, S. A. de C. V., ubicados en Municipio Libre 175, Nave Principal, Col. Portales, México D.F. Se terminó de imprimir en el mes de agosto de 2005. 